UNIVERSIDADE ESTADUAL PAULISTA

FACULDADE DE CIÊNCIAS

CAMPUS DE BAURU

PROGRAMA DE PÓS-GRADUAÇÃO EM EDUCAÇÃO PARA A CIÊNCIA

Daniela Cristina Maestro

CARACTERIZAÇÃo DE PRÁTICAS DE ENSINO E DELINEAMENTOS DE RECURSOS DIDÁTICOS PARA ÁREA CURRICULAR DE MATEMÁTICA NO ENSINO FUNDAMENTAL

BAURU

2010 


\section{Daniela Cristina Maestro}

CARACTERIZAÇÃO DE PRÁTICAS DE ENSINO E DELINEAMENTOS DE RECURSOS DIDÁTICOS PARA ÁREA CURRICULAR DE MATEMÁTICA NO ENSINO FUNDAMENTAL

Dissertação apresentada ao Programa de Pós-Graduação em Educação para a Ciência, Área de Concentração em Ensino de Ciências, da Faculdade de Ciências da UNESP/Campus de Bauru, como requisito à obtenção do título de Mestre em Ensino de Ciências, sob orientação do Prof. Dr. Jair Lopes Júnior. 
DIVISÃO TÉCNICA DE BIBLIOTECA E DOCUMENTAÇÃO UNESP - BAURU

Maestro, Daniela Crisitna.

Caracterização de práticas de ensino e delineamentos de recursos didáticos para área curricular de matemática no ensino fundamental / Daniela Cristina Maestro, 2010.

$102 \mathrm{f}$.

Orientador: Jair Lopes Jr.

Dissertação (Mestrado) - Universidade Estadual Paulista. Faculdade de Ciências, 2010

1. Matemática - Ensino. 2. Ensino Fundamental. 3. Práticas de Ensino. 4. Recursos didáticos. I - Universidade Estadual Paulista. Faculdade de Ciências. II - Título. 


\title{
CARACTERIZAÇÃO DE PRÁTICAS DE ENSINO E DELINEAMENTOS DE RECURSOS DIDÁTICOS PARA ÁREA CURRICULAR DE MATEMÁTICA NO ENSINO FUNDAMENTAL
}

\begin{abstract}
Dissertação apresentada ao Programa de Pós-Graduação em Educação para a Ciência, da Área de Concentração em Ensino de Ciências, da Faculdade de Ciências da UNESP/Campus de Bauru, como requisito à obtenção do título de mestre em Educação para a Ciência.
\end{abstract}

Banca Examinadora:

Presidente: Prof. Dr. Jair Lopes Junior

Instituição: UNESP - Universidade Estadual Paulista - Bauru

Titular: Profa. Dra. Márcia Cristina da Costa Trindade Cyrino Instituição: UEL - Universidade Estadual de Londrina

Titular: Prof. Dr. Nelson Antonio Pirola Instituição: UNESP - Universidade Estadual Paulista - Bauru 
Aos meus pais por estarem sempre ao meu lado, me apoiando, incentivando e permitindo que eu tenha o conforto para o meu crescimento. 


\section{AGRADECIMENTOS}

Ao meu orientador Dr. Jair Lopes Júnior pela dedicada orientação, sempre em busca da concretização deste trabalho e também pelo carinho em todas as conversas que tivemos e ainda teremos.

Aos professores Dr. Nelson Pirola e Dra. Márcia Cyrino pelas importantes contribuições quando do exame de qualificação e mesmo para a defesa, momento tão importante deste trabalho.

Aos colegas e amigos de trabalho que dedicaram seu tempo em discutir e me auxiliar no decorrer deste trabalho: Lúcia Nomiso, Maria Ângela e Mabi Batista.

A minha colega de aula e de trabalho, Deise Peralta por me ajudar, incentivando e me auxiliando sempre que eu a procurei.

A minha amiga Lilian Daltro pela paciência e pela de dedicação a mim, incentivo, carinho e apoio incondicional nos momentos em que mais precisei.

A MStech, empresa na qual trabalho, por ter acreditado em mim e me apoiado a realizar este estudo tão importante para minha formação.

A todos os meus professores da Pós-Graduação em Educação para a Ciência que me deram oportunidades para que eu chegasse até aqui. 
MAESTRO, D. C. Caracterização de práticas de ensino e delineamentos de recursos didáticos para área curricular de matemática no ensino fundamental. 2010. 173f. Dissertação (Mestre em Educação para a Ciência) - UNESP, Faculdade de Ciências, Bauru, 2010.

\section{RESUMO}

A proposta e as orientações curriculares do Ensino Fundamental para a área de Matemática e as Matrizes de Referência do SARESP preconizam conteúdos curriculares e expectativas de aprendizagem expressas sob a forma de competências passíveis de avaliação ao final dos Ciclos I e II. Este trabalho, fundamentado teoricamente na Análise do Comportamento, utilizou essas propostas para analisar registros em vídeo de aulas ministradas por docentes das $4^{\mathrm{a}}$. e $8^{\mathrm{a}}$. séries, sustentando dois objetivos: 1) caracterizar práticas de ensino de professores da rede estadual que ministram conteúdos de Matemática, com ênfase na identificação e na descrição de consistências entre as contingências de ensino registradas, os conteúdos ministrados e as competências explicitadas na documentação acima especificada; 2) verificar se a caracterização das práticas de ensino desses professores se constituiria em condição favorecedora para o delineamento de recursos didáticos para o ensino de conteúdos curriculares de Matemática previstos nesta mesma documentação. O primeiro objetivo justificou a execução das três etapas do Procedimento de Descrição e Análise, de acordo com a sequência: seleção dos registros em vídeo de duas unidades didáticas (UDs) e vinculação de habilidades e competências parametrizadas pelo SARESP às práticas de ensino de duas professoras; descrições e análises das interações observadas; síntese das análises das UDs, salientando as ocorrências de ações mais incidentes nas práticas de ensino das professoras. Pela síntese, constatou-se que as professoras prescindiram de (1) fornecer condições com as quais os alunos pudessem elaborar suas próprias respostas às atividades propostas e (2) apresentar conseqüências imediatas contingentes às respostas dos alunos; (3) explorar possíveis relações de controle das respostas fornecidas pelos alunos que divergiram daquelas previstas. Para o segundo objetivo, estabeleceu-se o Procedimento de Propostas para recursos didáticos também desdobrado em três etapas: a) descrição da programação do ensino de cada UD observada; b) resumo das principais características das práticas de ensino; c) delineamento do recurso didático. Os recursos delineados tiveram como subsídio características identificadas nas análises das práticas de ensino das professoras. Foram propostos dois recursos, um para cada professora e tema abordado nas UDs. Esses recursos exploraram a proposição de contingências de ensino considerando as três características acima assinaladas e derivadas da observação da atuação de cada docente. De acordo com as análises, mostra-se inconclusivo estimar correspondências entre o desempenho observado dos alunos com relação ao desenvolvimento das competências e das habilidades previstas, pois as condições de ensino elaboradas e a forma como estas foram conduzidas não forneceram subsídios suficientes para tal conclusão. A caracterização de possíveis relações de contingências a partir da análise das interações aluno - material didático - professor que ocorrem neste ambiente, mostra-se como alternativa para a elaboração de recursos didáticos, uma vez que estes podem ser delineados de modo a respeitar características da atuação profissional do professor, bem como ampliar as possibilidades de manifestação dos repertórios comportamentais que definem as aprendizagens desejadas.

Palavras-chave: Ensino Fundamental; Proposta Curricular; Matrizes de Referências; SARESP, práticas de ensino, recursos didáticos. 


\section{ABSTRACT}

The proposal and curricular guidelines for elementary school of Mathematics and São Paulo Student Performance Appraisal System (Sistema de Avaliação do Rendimento Escolar de São Paulo) - SARESP suggest curriculum content and learning expectations expressed as skills which could be assessed at the end of Cycles I and II. Basing on the Behavior Analysis theories, this study aimed to analyze video recorded 4th and 8th grade classes, considering two goals: 1) to characterize the educational practices of public school teachers, when teaching contents in mathematics with emphasis on identifying and describing consistencies among the recorded teaching contingencies, the contents taught as well as the skills explained in the documentation specified above and 2) to verify if the characterization of these teachers' educational practices would constitute in a favoring condition for the instructional design of educational resources for teaching mathematics contents provided in the same documentation previously mentioned The first goal justified the realization of the Analysis and Description Procedure, completing the three stages concerned, according to the following sequence: video recording selection of two teaching units (TUs) and linking skills and competencies parameterized by SARESP to the teaching practices of two teachers; descriptions and analysis of the observed interactions; synthesis of both TU analysis, pointing the most frequent actions in the teachers' educational practices. Through the synthesis referred, it was found that the teachers have chosen not (1) to provide conditions in which students could develop their own answers to the proposed activities and (2) to present immediate consequences related to the students' answers, (3) to explore possible relations for controlling the answers given by students who differed from those predicted previously. For the second goal, the Proposals Procedure for the Educational Resources was established and developed in three stages as well: a) description of the educational program of each TU observed; b) summary of the main characteristics of the educational practices, c) teaching resource design. The designed resources had as a subsidy the characteristics identified in the analysis of the teachers' educational practices. Two resources were proposed, one for each teacher and subject taught in the TUs. These resources have explored the proposition of the effective teaching considering the three characteristics identified above and derived from the performance observation for each teacher. According to the analyses, it was inconclusive to estimate correspondences between the observed performance of the students with respect to the development of the predicted competencies and skills, because the elaborated learning conditions and the way they were conducted did not provide sufficient subsidies for such a conclusion. The characterization of possible contingence relations based on the analysis of the student interactions - teaching materials - teacher that occur in this environment, is shown as an alternative to the development of educational resources, since they can be designed to address the professional performance characteristics of the teacher, as well as to expand the possibilities of presenting the behavioral repertoires which define the desired learning.

Key-words: Elementary School, curricular proposals; Reference Matrixes; SARESP, educational practices, educational resources. 


\section{Lista de llustrações}

Figura 1 - Máquina de Ensinar, Figura 3 (Skinner, 1968; p. 28) .........................................................22

Figura 2 - Máquina de Ensinar, Figura 5 (Skinner, 1968; p. 35) .........................................................23

Figura 3 - Exemplo da Legenda do Mapa do Serviço Metereológico, dia 31/03/2007 ............................ 77

Figura 4 - Exemplo do Mapa do Serviço Metereológico, dia 31/03/2007 ...............................................77

Figura 5 - Exemplo dos quadros que são montados por PMA na lousa. .................................................90

Figura 6 - Exemplo do Gráfico criado na Lousa - PMA .......................................................................99

Figura 7 - Exemplo do modelo utilizado por PRA ............................................................................. 103

Figura 8 - Exemplo do modelo alterado, depois dos recortes - PRA ................................................... 103

Figura 9 - Tela 1 - Recurso didático informatizado - PMA ...................................................................... 128

Figura 10 - Tela 2 - Recurso didático informatizado - PMA .................................................................. 129

Figura 11 - Tela 3 - Recurso didático informatizado - PMA ............................................................... 130

Figura 12 - Tela 4 - Recurso didático informatizado - PMA ................................................................. 130

Figura 13 - Tela de Feedback - Recurso didático informatizado - PMA............................................. 131

Figura 14 - Tela de Revisão sobre Tabela - Recurso didático informatizado - PMA.............................. 132

Figura 15 - Tela de Revisão sobre Tabela: Linha - Recurso didático informatizado - PMA................... 132

Figura 16 - Tela de Revisão sobre Tabela: Coluna - Recurso didático informatizado - PMA ................. 133

Figura 17 - Tela de Revisão sobre Tabela: Exemplo - Recurso didático informatizado - PMA............... 133

Figura 18 - Tela de Feedback - Recurso didático informatizado - PMA............................................... 134

Figura 19 - Tela 5 - Recurso didático informatizado - PMA ............................................................. 135

Figura 20 - Tela de Feedback - Recurso didático informatizado - PMA............................................. 136

Figura 21 - Tela de Feedback - Recurso didático informatizado - PMA.............................................. 136

Figura 22 - Tela 6 - Recurso didático informatizado - PMA ............................................................. 137

Figura 23 - Tela de Feedback - Recurso didático informatizado - PMA ............................................ 137

Figura 24 - Tela de Feedback - Recurso didático informatizado - PMA ............................................ 138

Figura 25 - Tela 7 - Recurso didático informatizado - PMA ............................................................. 138

Figura 26 - Tela de Feedback - Recurso didático informatizado - PMA............................................. 139

Figura 27 - Tela 8 - Recurso didático informatizado - PMA ............................................................ 140

Figura 28 - Tela 9 - Recurso didático informatizado - PMA ............................................................. 140

Figura 29 - Tela 1 - Recurso didático informatizado de PRA ........................................................... 147

Figura 30 - Tela 2 - Recurso didático informatizado de PRA ........................................................... 147

Figura 31 - Tela 3 - Recurso didático informatizado de PRA ........................................................... 149

Figura 32 - Tela $3 b$ - Aluno cumpriu a atividade proposta ........................................................... 149

Figura 33 - Tela 3c - Aluno deverá tentar cumprir a atividade novamente........................................ 150

Figura 34 - Tela 4 - Recurso didático informatizado de PRA .......................................................... 151

Figura 35 Tela 5 - Recurso didático informatizado de PRA................................................................ 152

Figura 36 - Tela 6 - Recurso didático informatizado de PRA ............................................................... 153

Figura 37 - Tela 7 - Recurso didático informatizado de PRA .............................................................. 154

Figura 38 - Aluno cumpriu a atividade proposta .......................................................................... 155

Figura 39 - Aluno deverá tentar cumprir a atividade novamente ......................................................... 156

Figura 40 Tela 8 - Recurso Didático Informatizado de PRA................................................................ 157

Figura 41 - Tela 9 - Recurso Didático Informatizado de PRA .............................................................. 158

Figura 42 - Tela 10 - Recurso Didático Informatizado de PRA ........................................................... 159

Figura 43 - Tela 11 - Recurso didático informatizado de PRA ............................................................. 160

Figura 44 - Tela 12 - Recurso didático informatizado de PRA .............................................................. 161

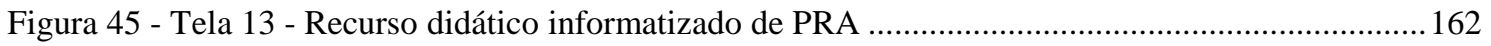

Figura 46 - Tela 14 - Recurso didático informatizado de PRA ......................................................... 163 


\section{Lista de Tabelas}

Tabela 1 - Áreas de Conteúdos e descrição das Habilidades para a 4ª série, p. 27..................................34

Tabela 2 - Eixos temáticos da Proposta Curricular do Estado de São Paulo p. 45-47 ..............................35

Tabela 3 - Matriz de referência com a descrição das competências e habilidades para a Área 1 de Matemática da 4a. Série do Ensino Fundamental, p. 66.........................................................................39

Tabela 4 - Matriz de referência com a descrição das competências e habilidades para a Área 1 de Matemática da 8a. Série do Ensino Fundamental, p. 78 ...................................................................40

Tabela 5 - Instrumento 1 de análise: Tabela de Caracterização das Habilidades Associadas .....................44

Tabela 6 - Instrumento 2 - Tabela Unidades de Análises ou Hipóteses ..................................................45

Tabela 7 - Dados do Recurso didático informatizado.............................................................................48

Tabela 8 - Tabela de Caracterização das Habilidades - UD 01 - PMA...................................................49

Tabela 9 - Tabela Unidades de Análises ou Hipóteses - H22 - PMA - UD - 01 ....................................51

Tabela 10 - Modelo das Tabelas de Estatura e Peso de Meninas e Meninos - PMA - UD - 01..................52

Tabela 11 - Tabela Unidades de Análises ou Hipóteses - H29 - PMA - UD - 01..................................54

Tabela 12 - Tabela Unidades de Análises ou Hipóteses - H22 - PMA - UD - 01 ..................................56

Tabela 13 - Tabela Unidades de Análises ou Hipóteses - H23 - PMA - UD - 01...................................58

Tabela 14 - Tabela Unidades de Análises ou Hipóteses - H10 - PMA - UD - 01..................................60

Tabela 15 - Tabela Unidades de Análises ou Hipóteses - H22 - PMA - UD - 01..................................61

Tabela 16 - Tabela Unidades de Análises ou Hipóteses - H23 - PMA - UD - 01..................................62

Tabela 17 - Tabela Unidades de Análises ou Hipóteses - H29 - PMA - UD - 01..................................71

Tabela 18 - Tabela de Caracterização das Habilidades - UD 02 - PMA ……............................................75

Tabela 19 - Tabela Unidades de Análises ou Hipóteses - H30 - PMA - UD - 02...................................76

Tabela 20 - Tabela Unidades de Análises ou Hipóteses - H17 - PMA - UD - 02..................................78

Tabela 21 - Tabela Unidades de Análises ou Hipóteses - H30 - PMA - UD - 02...................................79

Tabela 22 - Tabela Unidades de Análises ou Hipóteses - H22 - PMA - UD - 02..................................8 80

Tabela 23 - Tabela Unidades de Análises ou Hipóteses - H30 - PMA - UD - 02 ...................................81

Tabela 24 - Tabela Unidades de Análises ou Hipóteses - H22 - PMA - UD - 02..................................83

Tabela 25 - Tabela Unidades de Análises ou Hipóteses - H30 - PMA - UD - 02...................................8 89

Tabela 26 - Tabela Unidades de Análises ou Hipóteses - H29 - PMA - UD - 02..................................95

Tabela 27 - Modelo da tabela criada em aula - PMA …........................................................................96

Tabela 28 - Tabela Unidades de Análises ou Hipóteses - H30 - PMA - UD - 02 ...................................98

Tabela 29 - Tabela de Caracterização das Habilidades - UD 01 - PRA .................................................. 102

Tabela 30 - Tabela Unidades de Análises ou Hipóteses - H39 - PRA - UD - 01 .................................105

Tabela 31 - Tabela Unidades de Análises ou Hipóteses - H19 - PRA - UD - 01 ................................ 108

Tabela 32 - Tabela Unidades de Análises ou Hipóteses - H24 - PRA - UD - 01 ................................ 109

Tabela 33 - Tabela Unidades de Análises ou Hipóteses - H19 - PRA - UD - 01 ..................................112

Tabela 34 - Tabela de Caracterização das Habilidades - UD 02 - PRA ................................................ 114

Tabela 35 - Tabela Unidades de Análises ou Hipóteses - H36 - PRA - UD - 02 .................................. 119

Tabela 36 - Modelo das Tabelas de Estatura e Peso de Meninas e Meninos - PMA - UD - 01................ 122

Tabela 37 - Recurso didático informatizado - PMA .............................................................................. 126

Tabela 38 - Recurso didático informatizado - PRA ...................................................................... 145 


\section{Lista de Quadros}

Quadro 1 - Programação do Ensino - PMA - UD-01

Quadro 2 - Programação do Ensino - PMA - UD-02

Quadro 3 - Programação do Ensino - PRA - UD-01

Quadro 4 - Programação do Ensino - PRA - UD-01

Quadro 5 - Programação do Ensino - PRA - UD-02 


\section{SUMÁRIO}

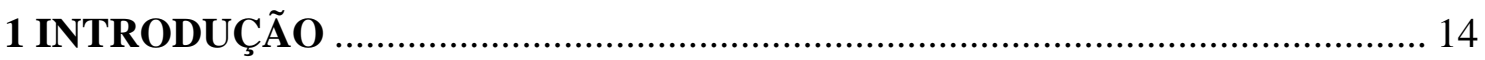

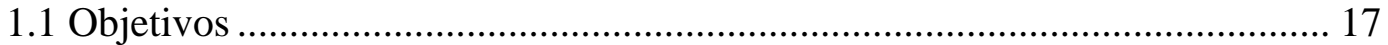

1.2 Apresentação da estrutura da redação desta pesquisa .................................... 18

2. FUNDAMENTAÇÃO TEÓRICA ………………………………………….... 19

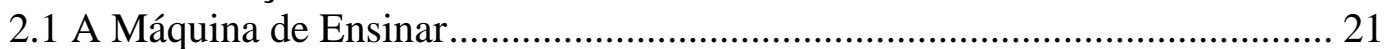

3. RECURSO DIDÁTICO INFORMATIZADO …………………………….... 27

4. A PROPOSTA CURRICUlar do ESTAdo de SÃo PAUlo E AS MATRIZES DE REFERÊNCIAS DO SARESP PARA O ENSINO FUNDAMENTAL DE MATEMÁTICA ……………………………………........ 31

4.1 Orientações Curriculares para Ensino Fundamental - CICLO I.................... 31

4.2 A Proposta Curricular do Ensino Fundamental - CICLO II ........................... 34

4.3 O Sistema de Avaliação do Rendimento Escolar do Estado De São Paulo -

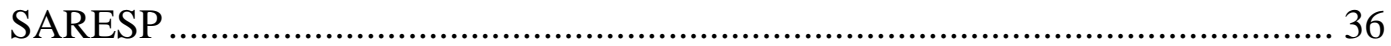

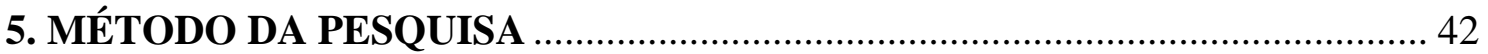

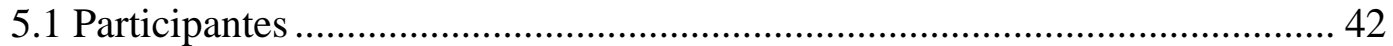

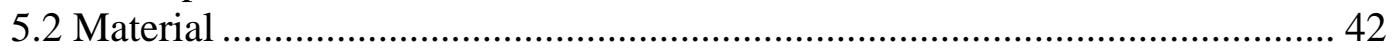

5.3 Procedimentos de Descrição e Análise ......................................................... 43

5.3.1 Etapa 1 - Caracterização das habilidades diante das práticas de ensino

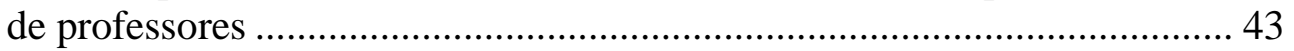

5.3.2 Etapa 2 - Descrição das habilidades a partir das interações registradas

e Análise das interações correspondentes às habilidades vinculadas .......... 45

5.3.4 Etapa 3 - Síntese das análises obtidas na Etapa 2 ............................ 46

5.4 Procedimentos de Propostas para recursos didáticos informatizados ............. 46

5.4.1 Etapa 1 - Descrever a programação do ensino das Unidades Didáticas

5.4.2 Etapa 2 - Elencar as características das práticas de ensino analisadas47

5.4.3 Etapa 3 - Delinear o recurso didático................................................... 47

6. RESULTADOS: DESCRIÇÃO E ANÁLISE ...................................................... 49

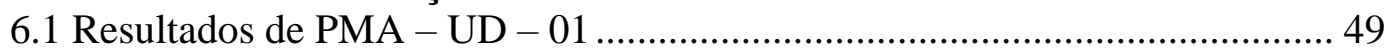

6.1.1 Etapa 1 - Caracterização das habilidades diante das práticas de ensino

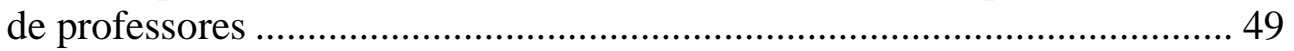

6.1.2 Etapa 2 - Descrição das habilidades a partir das interações registradas e Análise das interações correspondentes às habilidades vinculadas .......... 50

6.1.3 Etapa 3 - Síntese das análises obtidas na Etapa 2 da UD - 01 de PMA

6.2 RESULTADOS DE PMA - UD - 02 …................................................. 75

6.2.1 Etapa 1 - Caracterização das habilidades diante das práticas de ensino

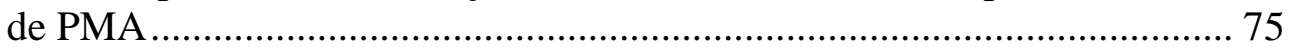

6.2.2 Etapa 2 - Descrição das habilidades a partir das interações registradas

e Análise das interações correspondentes às habilidades vinculadas .......... 76

6.2.3 Etapa 3 - Síntese das análises obtidas na Etapa 2 da UD - 02 de PMA

6.3 Resultados de PRA - UD - 01 ................................................................. 102

5.3.1 Etapa 1 - Caracterização das habilidades diante das práticas de ensino de PRA.

6.3.2 Etapa 2 - Descrição das habilidades a partir das interações registradas e Análise das interações correspondentes às habilidades vinculadas ........ 103 6.3.3 Etapa 3 - Síntese das análises obtidas na Etapa 2 da UD - 01 de PRA 


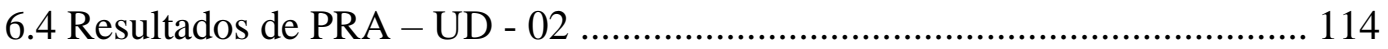
6.4.1 Etapa 1 - Caracterização das habilidades diante das práticas de ensino

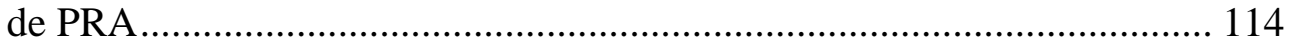
6.4.2 Etapa 2 - Descrição das habilidades a partir das interações registradas e Análise das interações correspondentes às habilidades vinculadas ........ 115

6.4.3 Etapa 3 - Síntese das análises obtidas na Etapa 2 da UD - 02 de PRA

7. RESULTADOS: ELABORAÇÃO DE PROPOSTAS PARA RECURSOS

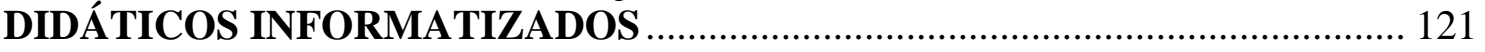

7.1 Recurso didático informatizado para PMA ................................................. 122

7.1.1 Etapa 4.1 - Descrever a programação do ensino das UDs ............... 122

7.1.2 Etapa 4.2 - Elencar as principais características das Práticas de Ensino

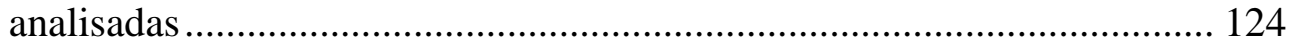

7.1.3 Etapa 4.3 - Delinear o recurso didático informatizado .................... 125

7.2 Recurso didático informatizado para PRA.................................................. 141

7.2.1 Etapa 4.1 - Descrever a programação do ensino das UDs - PRA .... 142

7.2.2 Etapa 4.2 - Elencar as principais características das Práticas de Ensino analisadas .................................................................................... 143

7.2.3 Etapa 4.3 - Delinear o recurso didático informatizado .................... 143

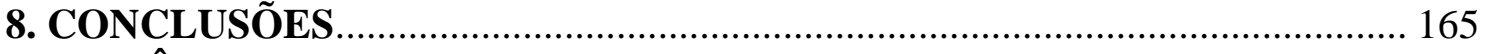

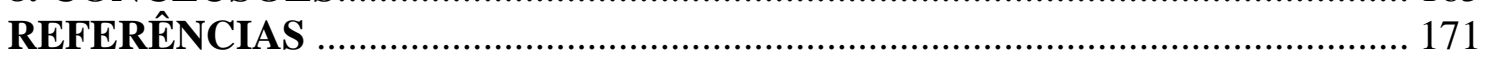




\section{INTRODUÇÃO}

"Não há nada a vencer senão a inércia cultural. Mas não será a disposição de não aceitar a tradição como algo inevitável a mais marcante característica do temperamento moderno?" (SKINNER, 1964; p. 26)

A caracterização de práticas de ensino proposta nesta dissertação insere-se num contexto mais amplo de estudo de práticas profissionais da docência. Por seu turno, o conjunto complexo de práticas profissionais que definem a docência encontra-se vinculado a programas de formação de professores que, em última estância, definem e especificam características distintas de ações que caracterizarão a atuação profissional do professor.

A formação de professores, concebida como processo contínuo, dinâmico e flexível que congrega uma dimensão individual de desenvolvimento de experiências e de conhecimentos pessoais, tanto quanto uma dimensão sócio-cultural de aprendizagens técnico e prática no cotidiano profissional, consolidou-se como um robusto campo de conhecimentos envolvendo diferentes modelos ou orientações epistemológicas.

Para Azevedo (2007, p. 33), “a discussão sobre qual o modelo formativo ideal para a docência remete a uma pluralidade de representações, concepções, teorias e propostas curriculares sobre o professor ideal e sua prática de ensino".

Dentre a pluralidade das concepções, Azevedo (2007, p. 34), destacou alguns autores e modelos de formação de professores, sendo que considerou os modelos não excludentes, embora, todos apresentem "interpretações distintas que podem se complementar" (p. 34).

O primeiro modelo de formação de professores descrito por Azevedo (2007) insere-se na concepção do professor como um artesão, que o caracteriza como um reprodutor de modelos, no qual o foco da formação é o saber-fazer. Neste entendimento sobre a profissão docente, é necessário desenvolver métodos e estratégias que conduzam tanto o ensino, quanto a aprendizagem. A prática de ensino, neste modelo, está baseada na subjetividade do professor e é deste entendimento que emerge a crítica a este modelo o esvaziamento da profissão, uma vez que a subjetividade está calcada na crença de que para ensinar basta "ou conhecer o conteúdo; ou ter talento; ou ter bom senso; ou seguir a intuição; ou ter experiência; ou ter cultura" (AZEVEDO, 2007, apud Gauthier et al.). 
Um segundo modelo, coloca o professor como técnico-científico, o caracterizando como um reprodutor de conhecimentos produzidos por cientistas e especialistas, sem, contudo, vincular a profissão docente a uma dimensão questionadora. Esse modelo, chamado de Modelo Hegemônico da Formação (AZEVEDO, 2007, apud Ramalho, Nuñez e Gauthier), tem sua fundamentação na formação tecnicista, de natureza positivista, o que considera críticas sobre a desvinculação da prática de ensino do contexto educacional, bem como sobre a dimensão instrumental e técnica associada a esta, desconsiderando o conhecimento construído pela e advindo da prática de ensino do professor.

A partir das críticas aos modelos de formação de professores que o consideram um técnico em sua profissão, emerge outro modelo de formação: Modelo Emergente da Formação, o qual fundamenta-se no discurso da valorização da profissão docente, por entender que o professor é um "agente ativo na produção do conhecimento sobre a docência" (AZEVEDO, 2007; p. 36), englobando aspectos sobre a prática de ensino e o contexto sóciopolítico escolar, que haviam sido desconsiderados por outros modelos, reivindicando a racionalidade prática como eixo norteador da formação docente (p. 37).

Nesta concepção sobre a formação do professor, a teoria dialoga com a prática docente, caracterizando o professor como um autor e ator de sua prática, na busca pela formação de profissionais críticos e reflexivos, ou seja, o professor se torna um intelectual crítico. Este professor deve ser valorizado dentro das dimensões do "conhecimento-na-ação, e a reflexão e a pesquisa na e sobre a prática docente" (AZEVEDO, 2007; p. 38).

Outro modelo considera o professor um profissional crítico-reflexivo, expandindo a atuação do professor em outros âmbitos, que vão além as ações pedagógicas em sala de aula, com reflexões sobre as políticas da educação e críticas ideológicas que podem contribuir para uma ação docente transformadora e libertária. Segundo Azevedo (apud Contreras, 2002), este modelo tem como pretensão integrar aos modelos, especialista técnico e profissional reflexivo, a postura cítrica que deve ser desenvolvida pelo professor.

Em ações paralelas às pesquisas acadêmicas sobre a formação de professores estão inseridas as ações governamentais, sejam em nível Federal, Estadual ou Municipal, que regulamentam/instituem leis que permeiam toda a política educacional das escolas públicas.

Essas ações de cunho político institucionalizam como a escola deve se comportar em relação às dimensões educacionais: como as aulas devem ser desenvolvidas, como uma avaliação deve ser conduzida, mediante ao estabelecimento de sistemas de ensino e avaliação de desempenho. 
Essas políticas públicas instituídas fornecem ao exercício profissional da docência uma característica, que muitas vezes, pode ser entendida dentro de um plano de formação tecnicista, voltado para a obtenção desempenhos, tanto do aluno, quanto do próprio professor, ao final de um ciclo, em conformidade a uma série de descritores, sob o discurso de que os resultados obtidos serão utilizados para análise e elaboração de novas estratégias com o foco da melhoria do processo de ensino e de aprendizado.

Segundo Bauer (2006, p.8), porém, o uso dos resultados de algumas avaliações, como a do Sistema de Avaliação de Rendimento Escolar de São Paulo (SARESP), por exemplo, está relacionado à equipe responsável no âmbito da Diretoria de Ensino (DE), sendo que algumas elaboram ações relacionadas à formação docente. No Estado de São Paulo, existem, atualmente, 91 diretorias de ensino, espalhadas por todo o Estado.

Outro resultado obtido por Bauer (2006) em sua pesquisa, é que as equipes das DEs apresentam dificuldades em compreender os resultados da avaliação do SARESP e, ainda, atribui a este fato, a consequência das diferentes ações que as equipes das DEs tomam com relação às ações posteriores à apresentação de resultados.

Bauer (2006, p. 8) ainda comenta que as muitas ações de formação de professores realizadas dentro das DEs estão delineadas/definidas dentro das expectativas da Secretaria da Educação, o que, para muitos professores, parecem ações desvinculadas dos resultados obtidos regionalmente pelas avaliações do SARESP.

Com isso, instala-se um conflito entre os esforços realizados pela academia, que busca a formação do professor crítico-reflexivo e as políticas públicas que intervém no dia-adia da escola de maneira a regulamentar como a profissão docente deve ser executada/desenvolvida.

Integrando-se a este cenário conflituoso, está o avanço das Tecnologias da Comunicação e Informação (TIC) que, paralelamente aos conflitos entre as pesquisas sobre a formação de professores e a instituição de políticas públicas, vem se consolidando como recursos para a mediação das relações de ensino e aprendizagem.

Este cenário fornece os três pilares que sustentam este trabalho: a caracterização da prática de ensino, as políticas públicas que avaliam desempenhos dos alunos e os avanços tecnológicos, como recursos didáticos. Sendo assim, este trabalho se propôs a investigar em que extensão as práticas de ensino de professores que ministram conteúdos de matemática no Ensino Fundamental - Ciclo I e II sustentariam assistências em duas dimensões da Proposta Curricular do Estado de São Paulo: a) com os conteúdos previstos; b) com as respectivas competências relacionadas às áreas e aos temas dos conteúdos ministrados. Deste modo, a 
seguinte indagação orientou as investigações ora propostas: a caracterização das práticas de ensino dos conteúdos curriculares de Matemática no Ensino Fundamental, aliada a Proposta Curricular do Estado de São Paulo e aulas ministradas por docentes da rede pública estadual poderiam se constituir em subsídios para propostas/delineamentos de recursos didáticos, em termo de práticas de ensino e de material de apoio didático?

Para responder a esta questão, este trabalho utilizou vídeos de aulas ministradas por dois professores do Ensino Fundamental, Ciclo I e II, de duas escolas da rede pública do Estado de São Paulo para analisar as interações ocorridas em sala de aula, diante do referencial teórico da Análise do Comportamento e as Matrizes de Referências do SARESP, para, então, propor recursos didáticos informatizados, que foram subsidiados pela análise posteriormente realizada.

\subsection{Objetivos}

Fundamentado teoricamente no modelo analítico comportamental, o presente projeto sustenta dois objetivos:

1. Caracterizar as práticas de ensino de professores da rede pública estadual que ministram conteúdos da matemática nos Ciclo I e II do Ensino Fundamental, com ênfase na identificação e na descrição de consistências entre as contingencias de ensino registradas e os conteúdos e competências preconizadas pela Proposta Curricular e pelas Matrizes de Referências do SARESP.

2. Verificar se a caracterização das práticas de ensino efetuadas no item anterior se constituiria em condição favorecedora para o delineamento de recursos instrucionais para o ensino de conteúdos curriculares da área de Matemática previstos na proposta curricular do Estado de São Paulo, bem como para o desenvolvimento das competências definidas nas Matrizes de Referência do SARESP. 


\subsection{Apresentação da estrutura da redação desta pesquisa}

A investigação realizada neste presente trabalho foi descrita e organizada em oito seções, encabeçadas pela primeira seção com a introdução, que em sua sequência, também apresenta os objetivos da pesquisa, e discorre até as conclusões, que apresentam as considerações compreendidas pelo estudo realizado. Além disso, para ilustrar os recursos didáticos propostos, foram utilizadas Figuras como meio de apresentação das propostas elaboradas.

$\mathrm{Na}$ segunda seção, é apresentado o referencial teórico da Análise do Comportamento, que norteia as análises das interações entre docentes e alunos das aulas ministradas e registradas em vídeo, bem como o delineamento das propostas de recursos didáticos informatizados.

A terceira seção apresenta o conceito com o qual o recurso didático informatizado é entendido neste trabalho e quais são suas funções, quando este se insere nas relações entre professor e aluno.

Em seguida, na quarta seção, foram apresentadas as orientações pedagógicas e as diretrizes curriculares provenientes das Propostas Curriculares do Estado de São Paulo para o Ensino Fundamental e as Matrizes de Referências do Sistema de Avaliação de Rendimento Escolar do Estado de São Paulo para a área de matemática, com o objetivo de situar este trabalho em uma perspectiva que fornecesse medidas de desempenho dos alunos, que poderiam subsidiar as análises das interações entre aluno e professor em sala de aula.

A quinta seção destinou-se a descrever a metodologia de pesquisa, composta por dois principais procedimentos: um para análise e descrição das interações entre docente e alunos, a partir da caracterização das habilidades associadas e outro para subsidiar o delineamento das propostas de recursos didáticos. As análises e caracterizações de práticas de ensino foram realizadas a partir de vídeos registrados de duas professoras do Ensino Fundamental da rede pública estadual de Bauru.

Na sexta seção deste trabalho, são discutidos os resultados obtidos pelas análises dos vídeos exibidos das aulas ministradas pelas professoras.

$\mathrm{Na}$ sétima seção são delineadas duas propostas de recursos didáticos informatizados, sendo uma proposta para cada professora, cujas aulas foram analisadas na seção anterior.

$\mathrm{Na}$ última seção, são apresentadas as conclusões deste trabalho, diante das análises e dos delineamentos dos recursos didáticos informatizados. 


\section{FUNDAMENTAÇÃO TEÓRICA}

Este estudo apresenta como fundamentação teórica preceitos advogados pela Análise do Comportamento, modelo científico derivado dos posicionamentos epistemológicos do Behaviorismo Radical, versão com especificidades conceituais e metodológicas distintas das demais versões de behaviorismo (BAUM, 1999; MATOS, 1997a; 1997b; SKINNER, 1945, 1972a; 1974). Admitir o Behaviorismo Radical e a Análise do Comportamento como mediação teórica equivale a centrar atenção nas interações entre o sujeito e as diferentes modalidades de ambiente nas quais tais interações ocorrem. Segundo o Behaviorismo Radical e a Análise do Comportamento (CARVALHO NETO, 2001; SKINNER, 1984), parte dos fatores que auxiliam na compreensão de propriedades de nossas ações estão dispostas no ambiente externo ao sujeito que se comporta, ao denominado ambiente intersubjetivo e publicamente observável. Contudo, a compreensão de propriedades relevantes de tais ações também depende de uma parcela significativa do ambiente estimado, em linguagem coloquial, como privado ou subjetivo, ou seja, de uma parcela do ambiente que se encontra sob a pele do sujeito que se comporta (SKINNER, 1957; TOURINHO, 1995). Destes posicionamentos decorre, no âmbito dos estudos sobre processos de ensino e de aprendizagem, que a Análise do Comportamento coloca-se como antagônica à qualquer mediação que assuma a natureza passiva dos aprendizes ou, em oposição igualmente questionável, uma natureza unilateralmente ativa. As pessoas, ao mesmo tempo em que, mediante comportamentos, agem sobre o mundo, por ele são diretamente influenciados numa relação dinâmica. O estudo dessas relações constitui-se em objeto prioritário de uma perspectiva científica para o estudo do comportamento humano denominado por Análise do Comportamento (SKINNER, 1953; 1972a; 1972b).

A característica mais relevante de uma interpretação fundamentada na Análise do Comportamento consiste, precisamente, na identificação de propriedades funcionais entre fenômenos. E tem como pressuposto que uma formulação adequada da interação entre um indivíduo e seu ambiente deve sempre especificar três fatores: (1) a ocasião em que a resposta ocorre; (2) a própria resposta; e (3) as consequências dessa resposta (MATOS, 1992).

Uma dimensão definidora do Behaviorismo Radical, enquanto orientação epitemológica, consiste em considerar que as "causas" das quais um determinado repertório comportamental é função sejam buscadas no contexto histórico e social no qual ocorreram as interações entre um sujeito que se comporta e as reações físicas e sociais deste ambiente a tais ações. O termo função descreve e especifica possíveis relações de dependência entre eventos 
históricos e sociais, externos e internos ao sujeito que se comporta, que antecederam ou foram subseqüentes às ações do sujeito, e essas respectivas ações ou respostas. Estima-se que os dados resultantes das observações sistemáticas de possíveis consistências entre estas propriedades destes três termos (eventos antecedentes, as ações do sujeito e eventos subsequientes) possam sugerir relações de funcionalidade. As investigações fundamentadas em tais preceitos devem priorizar a identificação de variáveis antecedentes e subseqüentes possivelmente relacionadas, de modo funcional, com propriedades de determinados repertórios.

Ao admitir, portanto, uma determinação funcional e probabilística do comportamento, o Behaviorismo Radical coloca-se em franca oposição aos modelos de causalidade mecânica e linear que ocupam significativa parcela no âmbito dos modelos científicos para o estudo do comportamento (SÉRIO, 2005). Skinner, reiteradamente, demarcou as diferenças do modelo de causalidade do Behaviorismo Radical que, enquanto funcional e probabilístico, fundamenta-se numa perspectiva de determinação histórica (SKINNER, 1945; 1953; 1971; 1981).

Analistas do Comportamento preferem a observação sistemática aos testes e ou medidas estatísticas, e a consideram como um dos principais instrumentos de coleta de dados acerca do comportamento e da situação ambiental, pois é através da observação da interação entre um individuo e o meio com o qual interage que podemos estudar e avaliar repertórios comportamentais, ou seja, como aprendemos, como pensamos, por que fazemos coisas do jeito que fazemos (SIDMAN, 1960).

No âmbito de uma interpretação analítico-comportamental admite-se que interpretar propriedades do desempenho dos alunos como função de condições e de características das práticas educativas efetivamente disponibilizadas pelo professor é um recurso que possibilita ao professor que ensina Matemática autonomia para avaliar a própria prática.

Em termos teóricos, portanto, temos o princípio analítico comportamental, segundo o qual, comportamento define-se por uma relação ou interação, diferentemente de uma resposta isolada ou determinada mecanicamente por uma estimulação que a elicia, que antecede sua ocorrência, tal qual preconizado nos modelos fundamentados nas contingências (unidades de análise) respondentes estímulo-resposta. No contexto desta importante demarcação conceitual que caracteriza o Behaviorismo Radical, enquanto mediação teórica, cabe ao professor avaliar a interação: comportamento (aprendizagem do aluno) - ambiente (condições de ensino antecedentes e conseqüentes às ações dos alunos dispostas pelo 
professor) e, alterando o ambiente (implementando novas estratégias), alterar o comportamento (desenvolver novas aprendizagens no aluno).

Numa perspectiva analítico-comportamental (SÉRIO, 2005; SKINNER, 1974), os professores devem desenvolver uma compreensão das circunstâncias em que ocorre o ensino, para avaliar o processo de aprendizagem do aluno, bem como o próprio processo de ensinar. A avaliação do aluno passa a ter então, um significado peculiar: avaliar o aluno requer avaliar as condições oferecidas a ele para aprender, inclusive a prática do próprio professor. A avaliação da aprendizagem passa a se constituir, ela mesma, como uma "condição adicional que possibilita ao professor rever e replanejar as condições de ensino disponíveis" (ZANOTTO, 2000; p. 125). Ao atribuir ao professor as funções de avaliar e de se avaliar, bem como ao propor que ele as realize segundo princípios de uma análise comportamental, Skinner reconhece no professor um agente fundamental de transformação na Educação (SKINNER, 1953; em especial, 5a . seção/capítulo XXVI).

\subsection{A Máquina de Ensinar}

"O êxito das máquinas depende do material didático que nelas for usado." (SKINNER, 1964; p. 37)

Nesta ultima década, com a massificação dos conhecidos PC (Personal Computer, que significa Computadores Pessoais, em português), as políticas de educação, sejam elas municipais, estaduais ou federais, incluem em seu conjunto de ações a implantação do uso do computador como um instrumento de apoio, sob diversas condições, em laboratórios de informática, sala de aula ou em quaisquer lugares, também chamada de Computação Umpara-Um.

Porém, a idéia de se utilizar "máquinas" como meio que possibilitem formas de aprender diferenciadas às utilizadas em sala de aula e, em consequência, a atividade de ensino do professor, data de alguns anos atrás.

Em 1968, Skinner, publicou o livro Tecnologia do Ensino, no qual ele uniu vários

trabalhos elaborados independentemente, que discutem, dentro das possibilidades dos recursos tecnológicos disponíveis na época, o uso de determinados recursos, traduzidos como Máquinas de Ensinar, na busca em melhorar o processo de ensino e de aprendizagem.

Skinner, na época utilizou o termo Máquinas de Ensinar para designar aparelhos, cujo objetivo de sua construção foi apresentar uma instrução planejada. Essas máquinas, que atualmente podem ser consideradas primitivas, apresentavam alguns elementos 
que possibilitavam a interação do aluno com o aparelho para responder questões de únicas escolhas ou múltiplas escolhas. Sendo assim, cada Máquina de Ensinar foi construída com uma intenção (a instrução programada) fechada, ou seja, o aparelho constituía a atividade em si. Já os computadores atuais são construídos de forma a conter vários programas (ou software) que permitem a programação de instruções de diversas instruções planejadas. Em resumo, um computador atual é capaz de representar, em meio digital, várias Máquinas de Ensinar, dependendo da programação elaborada por um professor.

Essas máquinas, diferentes dos computadores atuais que são construídos com componentes eletrônicos, eram circuitos elétrico-mecânicos, muitas delas pareciam com caixas de madeiras, como mostram as figuras a seguir:

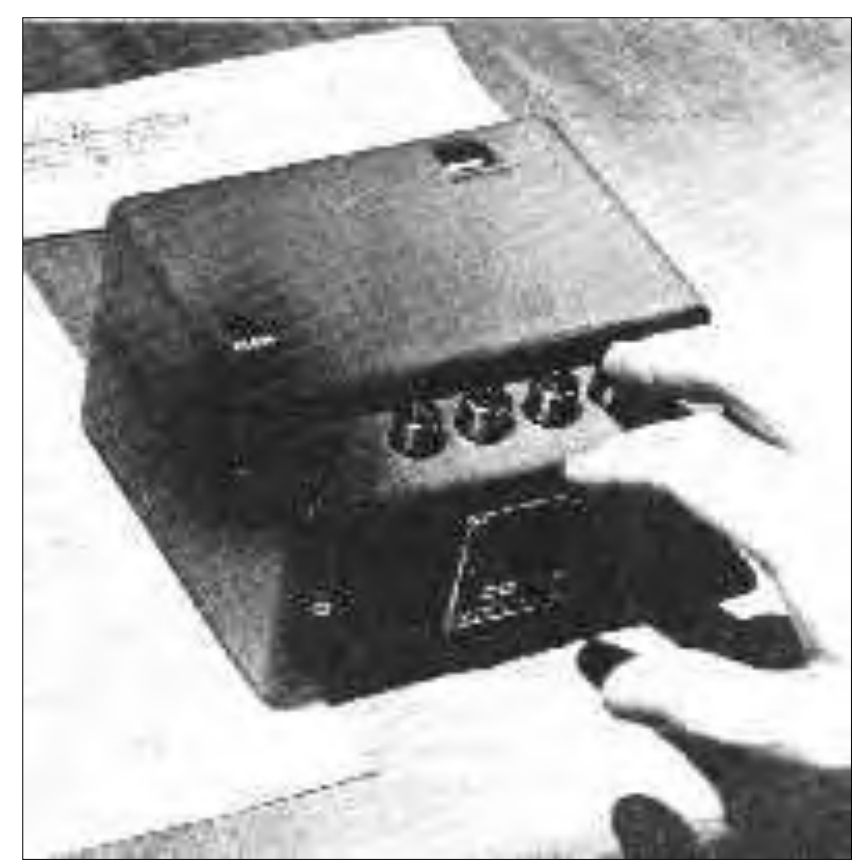

Figura 1 - Máquina de Ensinar, Figura 3 (Skinner, 1968; p. 28)

Ainda que essas Máquinas de Ensinar não apresentassem as mesmas possibilidades de interação que é possível acompanhar atualmente, dado avanço das Tecnologias da Informação e Comunicação, em termos de conexão em rede, software e hardware, estas apresentavam possibilidades de interação, que, no entendimento de Skinner (1968, pg. 30), estabelecia uma participação ativa do aluno.

Os exercícios eram apresentados em uma sequência planejada, na qual, apenas um exercício era apresentado por quadro. Com isso, esperava que a atenção do aluno volta-se 
apenas ao exercício que ele deveria responder. Geralmente, nessas máquinas, a interação era realizada pressionando botões, por botões giratórios ou pela escrita da resposta em fitas de papeis, como mostra a figura a seguir:

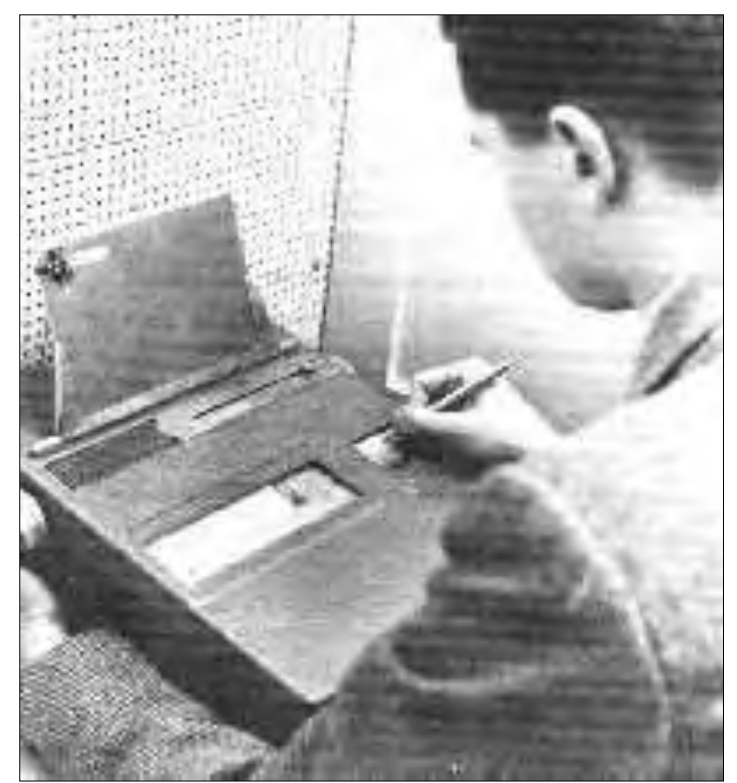

Figura 2 - Máquina de Ensinar, Figura 5 (Skinner, 1968; p. 35)

Ao responder a questão, o aluno deveria girar botão ou mover uma alavanca para receber o feedback de sua resposta: se estava ou não correta. Algumas máquinas permitiam que o aluno tivesse acesso à próxima questão somente se a resposta estivesse correta; outras permitiam que o aluno continuasse em seus exercícios, mas voltasse às questões com respostas incorretas. Com isso, a apresentação das consequências era imediata e contingente às ações do aluno.

A programação das consequências imediatas e contingentes (ou seja, que ocorrem em função de) às ações dos alunos é de extrema importância, sendo que a sua compreensão no âmbito do modelo interpretativo da Análise do Comportamento impõe cautela e rigor.

Um aspecto característico e definidor da proposta epistemológica protagonizada por B. F. Skinner foi a defesa veemente da importância das consequências para o estabelecimento de determinadas classes de resposta. Alem da ênfase nas consequências, a saber, nos eventos que ocorrem contingentes à emissão de determinadas respostas, Skinner igualmente ressaltou dois aspectos relacionados a tais eventos.

O primeiro refere-se ao período ou intervalo de tempo transcorrido entre a emissão 
da resposta e o contato com as consequências. Num extremo teríamos as consequências imediatas, ou seja, aqueles eventos que, de modo natural ou programado, são liberados ao final da emissão da resposta. Nestes termos, o planejamento das máquinas de ensinar envolvia necessariamente a programação do fornecimento de consequências imediatas contingentes (ou seja, dependentes) da resposta anterior do aluno. Tais consequências, sob a forma de indicação de acerto e acesso para uma próxima etapa ou de erro com manutenção da etapa ou retrocesso às etapas anteriores, seriam produzidas pela ação direta do aluno.

No outro extremo teríamos as denominadas consequências remotas, ou seja, consequências demoradas, eventos que, embora contingentes à emissão da resposta, não ocorrem de modo imediato após a resposta.

Skinner reiteradamente apontou as diferenças entre consequências imediatas e remotas para o estabelecimento de classes de respostas operantes, ou seja, classes de respostas que são alteradas pelos seus efeitos. Além de mencionar as diferenças, Skinner também argumentou que, no âmbito da Educação, as consequências imediatas são de grande relevância, sendo que, em oposição, consequências remotas podem comprometer de modo significativo algumas aprendizagens.

Um exemplo simplificado talvez ilustre os argumentos de Skinner. Suponha uma contingência planejada que estabeleça que o aluno imediatamente após entregar sua avaliação de aprendizagem receberá consequências sob a forma de visualizações da resolução correta e do gabarito. Tal contingência muito provavelmente produzirá efeitos diferentes e, quiçá, mais satisfatórios do que outra contingência que prevê o contato do aluno com a correção e a nota após quinze dias, por exemplo.

Skinner (1968) advogando a relevância das consequências imediatas para o contexto do ensino, em especial, o ensino escola, e, por outro lado, reconhecendo a complexidade das ações profissionais do professor, argumentou que seria inaceitável concentrar toda a responsabilidade pelo procedimento das consequências, de modo imediato, no professor.

$\mathrm{Na}$ argumentação de Skinner, embora da importância inconteste para o ensino e a aprendizagem, a libertação de consequências imediatas poderia ficar a cargo da máquina de ensina, cabendo ao professor tarefas mais complexas de planejamento, de adequação de conteúdos, tanto quanto de programação de tais consequências de modo contingente e imediato às ações e às participações de cada aluno.

O segundo aspecto destacado por Skinner residiu em salientar que a relação entre a emissão de uma resposta e a produção de uma dada consequência ocorre sempre diante de 
um contexto, de uma condição antecedente. Tal contexto ou condição antecedente pode adquirir diferentes funções. Uma função, denominada como $S^{D}$, consiste em sinalizar que na presença de tal contexto antecedente (estímulo), a emissão de uma determinada resposta apresenta alta probabilidade de produzir consequências. Outra função, por sua vez, denominada como $\mathrm{A}^{\mathrm{S}}$, sinaliza que na presença deste estímulo é fraca ou nula a relação entre a emissão da resposta e a produção da consequência.

A relação entre estímulos antecedentes, respostas emitidas e os efeitos produzidos por tais respostas é denominada por controle de estímulos, e dessa forma, uma análise da sequência das respostas conduziria até os elementos importantes para identificar o raciocínio que levou o indivíduo a uma resposta (de Rose, 2004). Para que essa identificação seja possível, é necessária uma cuidadosa programação instrucional (didática) de um material. Para SKINNER (1968, p. 37), “a própria máquina, naturalmente, não ensina. Põe simplesmente o estudante em contato com a pessoa que preparou o material que a máquina apresenta". Além disso, a própria máquina apresenta um novo "contexto" para a aprendizagem do aluno e seu feedback imediato, proporcionava a mudança da frequência ou probabilidade de uma ou mais ações: com uma resposta incorreta, o aluno não poderia progredir na tarefa elaborada.

Outra característica muito citada por Skinner durante seus estudos sobre as Máquinas de Ensinar é a questão do tempo. Para ele, embora um professor possa acompanhar toda a classe na interação com a máquina, cada aluno progride em seu próprio ritmo, ou seja, cada aluno responde ou é afetado de modo diferente, idiossincrática, pessoal, pelas contingências planejadas pelo professor. Com isso, "a probabilidade de que um comportamento apropriado ocorra, de fato, no tempo devido" (SKINNER, 1964; p. 31), designado como motivação, é maior.

Caso seja possível classificar o uso dessas máquinas bom uso e mal uso, isso dependerá inteiramente do planejamento do material a ser apresentado por elas e nelas e, consequentemente dos arranjos das contingencias que possam permear a inclusão de tal uso no planejamento de ensino do professor.

Para Skinner (1968, p. 36-37), o uso das Máquinas de Ensinar pode ser comparado ao efeito de um aluno estudando ou aprendendo com um professor particular, sendo que essa comparação é sustentada diante das seguintes hipóteses: 
máquina [...] reforça o aluno para cada resposta correta, usando este feedback imediato não só para modelar mais eficientemente o comportamento como para mantê-lo forte. (SKINNER, 1968, p. 37).

Os efeitos causados nos alunos são descritos em termos de hipóteses, pois, cada uma das proposições anteriormente citadas apenas tornam-se fatos, mediante ao planejamento de ensino elaborado pelo professor, ou seja, "através da construção ordenada do programa e, em parte, através de técnicas tais como sugerir, dar a entender e apontar".

O feedback imediato deve ser delineado dentro dessa proposta didática do professor e este elemento é o que mantém o interesse do aluno. Neste ponto, quando o programa tem a possibilidade, devido ao tipo de instrumento no qual está inserido, de introduzir novas variáveis de controle sobre a aprendizagem do aluno.

Um instrumento como as Máquinas de Ensinar permite ao professor acompanhar todos os seus alunos, ainda que cada um imprima ao processo de interação e resolução de exercícios o seu ritmo, de forma a ter em mãos um instrumento que possibilidade a avaliação do desempenho do aluno.

Sendo assim, ao planejar um conteúdo a ser utilizado em uma máquina como esta, é necessário que o professor utilize técnicas que permitam evocar formas específicas de comportamento e colocá-las sob controles de estímulos específicos, por meio de reforços diferenciados. 


\section{RECURSO DIDÁTICO INFORMATIZADO}

A busca por novas formas de ensinar e de aprender está sendo influenciada pelas mudanças aceleradas. Essas mudanças que nossa sociedade, de forma geral, vem sofrendo está relacionada, principalmente, aos avanços tecnológicos. Essa busca, então influenciada pelos avanços tecnológicos, inclui o uso do computador, recursos digitais ou outros artefatos tecnológicos, sendo todo esse conjunto de recursos digitais: visuais, audiovisuais, textuais, acessados pela Internet ou não, configurados pelas Tecnologias da Informação e Comunicação (TIC).

O uso da TIC pode provocar profundas transformações no processo de ensino e de aprendizagem, situando a aprendizagem de um determinado conteúdo, que antes era difundido apenas em sala de aula, em uma relação de espaço e tempo mais abrangentes.

Embora não exista um consenso sobre os limites da aplicação das TIC na área da Educação (BARRETO, 2004; p. 1182), isso se apresenta cada vez mais inserido no contexto escolar. Para Melaré (2005, p.74) o uso dos computadores pode enriquecer o processo de ensino e aprendizagem. Nesta linha de pensamento, é possível acompanhar, pela mídia e pesquisas na Internet, algumas das iniciativas governamentais de informatização das escolas sejam em âmbito administrativo ou na criação/construção de laboratórios de informática, que encerram a discussão sobre a importância deste tipo de ação em uma escola.

Em consequência, recai sobre o professor a tarefa de incorporar em suas práticas pedagógicas o uso das TIC de forma adequada e condizente, que permitam o desenvolvimento de habilidades e competências no aluno, que o levem a lidar com diferentes situações, resolver problemas imprevistos, ser flexível e estar em constante processo de formação. Porém, como já dito anteriormente, ainda não há consenso sobre os limites de aplicação, tampouco sobre como deve ser aplicada. É nesta contração que se situa o desafio do professor: planejar tarefas utilizando recursos, cuja aplicação ainda está em estágio embrionário, levando em consideração que a inclusão do uso dessas ferramentas pode modificar o papel do próprio professor dentro do processo de ensino e de aprendizagem.

O professor, então, além de ter que trabalhar as questões de planejamento do uso da TIC, também deve ter um esforço no sentido de conhecer quais são as possibilidades que as TIC oferecem, aliando essas possibilidades às condições técnicas apresentadas nos laboratórios de informática das aulas, que, a saber, apresentam outro desafio: nem todas as escolas possuem um laboratório que possam acomodar o total de alunos de uma sala de aula. 
Este é outro desafio que, necessariamente, deve ser transposto pelo professor com criatividade em seu planejamento.

Voltando a primeira questão: que seria conhecer as possibilidades das TIC, estas se apresentam bastante extensas, devido ao conjunto de tarefas que podem ser elaboradas. Existem recursos - a saber: software em conformância a hardware - construídos com várias intenções, direcionados a vários públicos-alvo. De Acordo com Gil-Pérez (2006, apud Risley e Redish, 1989; BARBERÁ E SANJOSÉ; 1990): “na estruturação das atividades, pode-se recorrer ao uso do computador sob diversas formas - simulação de experiências, modelizações, exercícios de auto-regulação e outros".

Portanto, existem várias estratégias que podem ser aplicadas para o uso das TIC em tarefas escolares, desde o uso de recursos prontos, até novas elaborações em termos de materiais didáticos. A elaboração de materiais didáticos revela-se em uma das possíveis estratégias do uso da TIC, sob diversos formatos, como vídeos, apresentações digitais, textos, simulações, animações, entre outros.

A autoria de material didático, por sua vez, também pode assumir vários conceitos dentro da computação, uma das alternativas é o Objeto de Aprendizagem. O Objeto de aprendizagem constitui um padrão para a elaboração de material didático que, num contexto digital, pode ser entendido como qualquer recurso digital que pode ser reutilizado para apoiar a aprendizagem ${ }^{1}$ (WILEY, 2000; p. 7). Sendo assim, uma imagem, um vídeo, um recorte de um texto, desde que inseridos em uma intenção e/ou objetivo de aprendizagem, podem ser considerados como um objeto de aprendizagem.

Segundo MELARÉ (2005, p. 73), os objetos de aprendizagem "constituem-se em um novo parâmetro educativo que utiliza a elaboração de um material didático envolvendo conteúdos, interdisciplinaridade, exercícios e complementos". Todos esses elementos envolvidos em sua construção, o torna um formato digital flexível: podendo ser concebido com a intenção de representar um conceito bastante amplo, como também apenas parte dele e, ainda, em combinação a diferentes objetivos de aprendizagem. Segundo NUNES (2004, p. 1), "Existem objetos de aprendizagem muito bons para motivar ou contextualizar um novo assunto a ser tratado, outros ótimos para visualizar conceitos complexos, alguns que induzem o aluno a certos pensamentos, outros ideais para uma aplicação inteligente do que estão aprendendo".

\footnotetext{
${ }^{1}$ Tradução livre de "any digital resource that can be reused to support learning".
} 
Com o uso de objetos de aprendizagem, o professor tem possibilidades para reprogramar atividades que, habitualmente são realizadas pelos alunos em sala de aula ou para preparar atividades que possam contribuir para a aprendizagem de conteúdos não observáveis, como evolução dos seres vivos, respiração celular, genética clássica, distribuição dos elétrons no átomo. Segundo BASTOS et al. (2005, p. 9), o ensino de conteúdos não observáveis por meio de atividades práticas são escassas ou mesmo inexistentes, além de apresentarem dificuldades de execução, como: “(a) as atividades correspondentes requereriam laboratórios sofisticados; (b) as atividades correspondentes requereriam um tempo de que não se dispõe; (c) as observações necessárias colocariam os alunos em risco; (d) as evidências que sustentam a teoria são escassas ou pouco observáveis". Sendo assim, os objetos de aprendizagem, dependendo de como forem construídos, podem representar fenômenos científicos por meio de animações e/ou simulações, no qual tanto o fenômeno, quanto o tempo necessário para que o fenômeno ocorra são simulados.

Uma das intenções do uso dos Objetos de Aprendizagem é facilitar a relação entre professor, conteúdo e alunos. O Objeto de Aprendizagem surge, então, como um instrumento de apoio às práticas de ensino, fornecendo ao professor "maior flexibilidade para se adaptar ao ritmo e ao interesse dos alunos, mantendo seus objetivos de ensino" (NUNES, 2004; p. 2). Sendo assim, é importante saber que os objetos de aprendizagem podem ser aplicados de forma bastante ampla e esta abrangência está intimamente ligada a sua forma de construção, que depende das intenções e objetivos planejados pelo professor e como serão realizadas as relações entre esses objetos e as atividades a serem realizadas pelos alunos.

Cabe ressaltar que a incorporação do Objeto de Aprendizagem ao processo de aprendizagem do aluno, não substitui ou minimiza as responsabilidades de um professor. $\mathrm{O}$ Objeto de Aprendizagem apenas fornece possibilidades de ampliar o repertório de instrumentos que possam contribuir para o processo de ensino e de aprendizagem. Segundo MELARÉ (2005, p. 74), “as tecnologias interativas aplicadas na educação permitem ampliar a pluralidade de abordagens, atender a diferentes estilos de aprendizagem e, desta forma, favorecer a aquisição de conhecimentos, competências e habilidades”.

Porém, elaborar um Objeto de Aprendizagem ou qualquer material didático que faça uso da TIC é um processo trabalhoso para o professor, que muitas vezes, não tem familiaridade com as TIC. Pelo estudo apresentado por Barreto et al. (2006), de 1996 a 2002, o número de dissertações e teses, que abordam a questão da Formação de Professores no uso de TIC é de 88 produções do Brasil. O que as autoras observaram é que de 2000 a 2002, os 
estudos voltados para esta área foram tomando mais espaço e, este fato, foi devido aos inúmeros investimentos governamentais em nível federal.

A preparação do professor, portanto, segundo, NUNES (2004, p. 2), exige muitas sessões para discussões "sobre o processo de ensino e aprendizagem e o quanto a disponibilidade de recursos dos mais diferentes tipos pode trazer de flexibilidade e ganhos na aprendizagem dos alunos devem ser realizadas", pois, o professor, dentro de sua estratégia de ensino, precisava visualizar neste recurso as possibilidades de mudanças nas interações que irão acontecer entre ele e seus alunos à medida que o objeto for inserido nestas relações, pesquisar por novas informações, recursos e suas possibilidades, bem como refletir sobre a utilização de novas ferramentas.

Além disso, também faz-se necessário saber que apenas a incorporação dos Objetos de Aprendizagem às práticas de ensino não representa garantias da "transformação efetiva e qualitativa nas práticas pedagógicas" (KONRATH et al., 2006, p. 1), pois, neste novo contexto, que pode ser estabelecido durante uma aula, há mudanças nas concepções sobre a função do professor no processo de ensino e de aprendizagem, explorando situações em sala de aula que façam com que os alunos interajam, troquem informações, debatam e raciocinem sobre os conteúdos a serem estudados. Desta forma, os repertórios de conhecimentos vão sendo adquiridos por meio da interação com a qual os alunos intervêm no seu ambiente e por meio das ferramentas que estão ali disponibilizadas.

Neste trabalho, entendemos que as TIC, dentro da aplicação na área de Educação, bem como a elaboração de materiais didáticos, também chamados de objetos de aprendizagem, são recursos didáticos informatizados, que representam meios pelos quais um professor poderá construir uma atividade ou tarefa com a intenção de inserir um recurso que possa mediar a interação entre: professor - conteúdo - aluno.

Sendo assim, um dos objetivos desta dissertação é explorar os recursos metodológicos que poderiam viabilizar a caracterização de práticas profissionais, sendo que tal caracterização poderia subsidiar a proposição de recursos didáticos.

Tanto as práticas profissionais, quanto o recurso didático foram analisados e propostos, respectivamente, admitindo-se como referência a Proposta Curricular do Estado de São Paulo e as matrizes de referência do SARESP. 


\section{A PROPOSTA CURRICULAR DO ESTADO DE SÃO PAULO E AS MATRIZES DE REFERÊNCIAS DO SARESP PARA O ENSINO FUNDAMENTAL DE MATEMÁTICA}

O Estado de São Paulo, seguindo as diretrizes advindas do MEC sobre a adequação das diretrizes às especificidades da realidade dos estados, elaborou a Proposta Curricular do Estado de São Paulo (GOVERNO DO ESTADO DE SÃO PAULO, 2008c), um documento com diretrizes que seguem as dos PCNs, mas que incorpora necessidades tidas pelos seus autores como próprias da realidade educacional paulista e que, se apresenta como um conjunto de orientações pedagógicas aos profissionais que integram a rede estadual paulista de ensino público. Esta publicação divide o Ensino Fundamental em Ciclo I ( $1^{\mathrm{a}}$ a $4^{\mathrm{a}}$ série) e Ciclo II ( $5^{\mathrm{a}}$ a $8^{\mathrm{a}}$ séries).

Com o intuito de subsidiar o ensino dos conteúdos curriculares mais relevantes a serem garantidos ao longo das quatro séries do Ciclo I do Ensino Fundamental é apresentado o documento “Orientações Curriculares do Estado de SP - Língua Portuguesa e Matemática" (GOVERNO DO ESTADO DE SÃO PAULO, 2008B). Outro propósito, segundo o próprio documento, é contribuir para a reflexão e discussão dos professores com a indicação do que os alunos deverão aprender, progressivamente, durante as quatro séries do Ciclo I.

Como medida de desempenho dos alunos que estudam o Ensino Fundamental e o Ensino Médio, o Estado de São Paulo criou seu Sistema de Avaliação de Rendimento Escolar - SARESP (GOVERNO DO ESTADO DE SÃO PAULO, 2009a), que constitui uma avaliação externa, com o objetivo de obter informações sobre a aprendizagem dos alunos da rede estadual de São Paulo.

\subsection{Orientações Curriculares para Ensino Fundamental - CICLO I}

O documento Orientações Curriculares documenta as expectativas de aprendizagem de Língua Portuguesa e Matemática dos alunos que se encontram entre as $1^{\mathrm{a}}$. e 4 . séries do Ensino Fundamental - Ciclo I. Para o presente estudo, o olhar para este documento voltou-se às expectativas apresentadas para a disciplina de Matemática e o papel do professor em sala de aula como mediador do processo de aprendizagem.

Segundo o documento, o professor deve "ser o mediador entre o conhecimento matemático e o aluno" (GOVERNO DO ESTADO DE SÃO PAULO, 2008b). Para que esta 
mediação ocorra, o documento ainda, de maneira sucinta, descreve no tópico Aprender e ensinar Matemática como deve ser o papel do Professor e o do Aluno, bem como as considerações que devem ser feitas pelo professor ao ensinar Matemática. Sendo assim, espera-se que o professor, como mediador do processo de aprendizagem, compreenda a matemática como uma ciência viva, conheça os conceitos e procedimentos matemáticos, bem como os procedimentos didáticos para ensiná-los.

Além dos conhecimentos técnicos específicos que estão envolvidos no processo de aprendizagem, o professor deve levar em consideração as características cognitivas, sociais e culturais dos alunos para, desta forma, compreender quais são obstáculos apresentados pelos alunos na aprendizagem da Matemática.

Sendo o papel do professor o de mediar, cabe ao aluno, então, o papel ativo, que foi denominado como agente da construção do conhecimento. A idéia de o aluno ser um agente de construção do conhecimento confere ao professor a tarefa de estimulá-lo a buscar o estabelecimento de conexões, ou seja, utilizar os conceitos e procedimentos aprendidos para resolver problemas. Além disso, o documento ainda propõe que a interação entre os alunos possibilita a ampliação do próprio pensamento.

A proposta das Expectativas da Aprendizagem para a Matemática quanto aos procedimentos e atitudes a serem desenvolvidos pelos alunos durante os quatro anos do Ensino Fundamental - Ciclo I e demonstrados ao final deste ciclo, abrangem objetivos gerais de aprendizagem, que descrevem alguns repertórios que os alunos devem apresentar ao final do Ciclo I. Os objetivos gerais apresentados no documento (GOVERNO DO ESTADO DE SÃO PAULO, 2008b) são sete, sendo eles:

(1) Compreender que os conhecimentos matemáticos são meios para entender a realidade;

(2) Utilizar os conhecimentos matemáticos para investigar e responder a questões elaboradas a partir de sua própria curiosidade;

(3) Observar aspectos quantitativos e qualitativos presentes em diferentes situações e estabelecer relações entre eles, utilizando conhecimentos relacionados aos números, às operações, às medidas, ao espaço e às formas, ao tratamento das informações;

(4) Resolver situação-problema a partir da interpretação de enunciados orais e escritos, desenvolvendo procedimentos para planejar, executar e checar soluções (formular hipóteses, fazer tentativas ou simulações), para comunicar 
resultados e compará-los com outros, validando ou não os procedimentos e as soluções encontradas;

(5) Comunicar-se matematicamente apresentando resultados precisos, argumentar sobre suas hipóteses, fazendo uso da linguagem oral e de representações matemáticas e estabelecendo relações entre elas;

(6) Sentir-se seguro para construir conhecimentos matemáticos, incentivando sempre os alunos na busca de soluções;

(7) Interagir com seus pares de forma cooperativa na busca de soluções para situações-problema, respeitando seus modos de pensar e aprendendo com eles.

Ainda neste documento, as expectativas de aprendizagem quanto aos conteúdos de Matemática estão organizadas e categorizadas em cinco grandes áreas, sendo elas: (1) Números; (2) Operações; (3) Espaço e forma; (4) Grandezas e medidas; (5) Tratamento da Informação. Essa organização proposta está agrupada por série do Ensino Fundamental Ciclo I. Porém, as expectativas são descritas em termos das medidas de desempenho esperadas pelos alunos, como demonstra a Tabela 1, que contém um recorte das Expectativas de Aprendizagem para Matemática da quarta (4 ${ }^{\mathrm{a}}$.) série do Ensino Fundamental - Ciclo I. Este recorte foi intencionalmente realizado, pois as análises realizadas neste trabalho focam este nível de escolaridade.

\begin{tabular}{lll} 
Conteúdos & Habilidades \\
\hline Números & - Compreender e utilizar as regras do sistema de numeração decimal. \\
& - Reconhecer e representar números racionais. \\
& - Explorar diferentes significados das frações em situações-problema: parte-todo, \\
& quociente e razão. \\
& - Escrever e comparar números racionais de uso freqüente, nas representações \\
& fracionária e decimal. \\
- & Identificar e produzir frações equivalentes. \\
\hline Operações & Compreender diferentes significados das operações envolvendo números \\
& naturais. \\
& Resolver adições e subtrações com números naturais, por meio de estratégias \\
& pessoais e do uso de técnicas operatórias convencionais. \\
& Resolver multiplicações e divisões com números naturais, por meio de estratégias \\
& pessoais e do uso de técnicas operatórias convencionais. \\
& Compreender diferentes significados da adição e subtração, envolvendo números \\
& racionais escritos na forma decimal. \\
& Resolver operações de adição e subtração de números racionais na forma \\
& decimal, por meio de estratégias pessoais e pelo uso de técnicas operatórias \\
& convencionais. \\
& Resolver problemas que envolvem o uso da porcentagem no contexto diário, \\
& como $10 \%, 20 \%, 25 \%, 50 \%$. \\
\hline
\end{tabular}




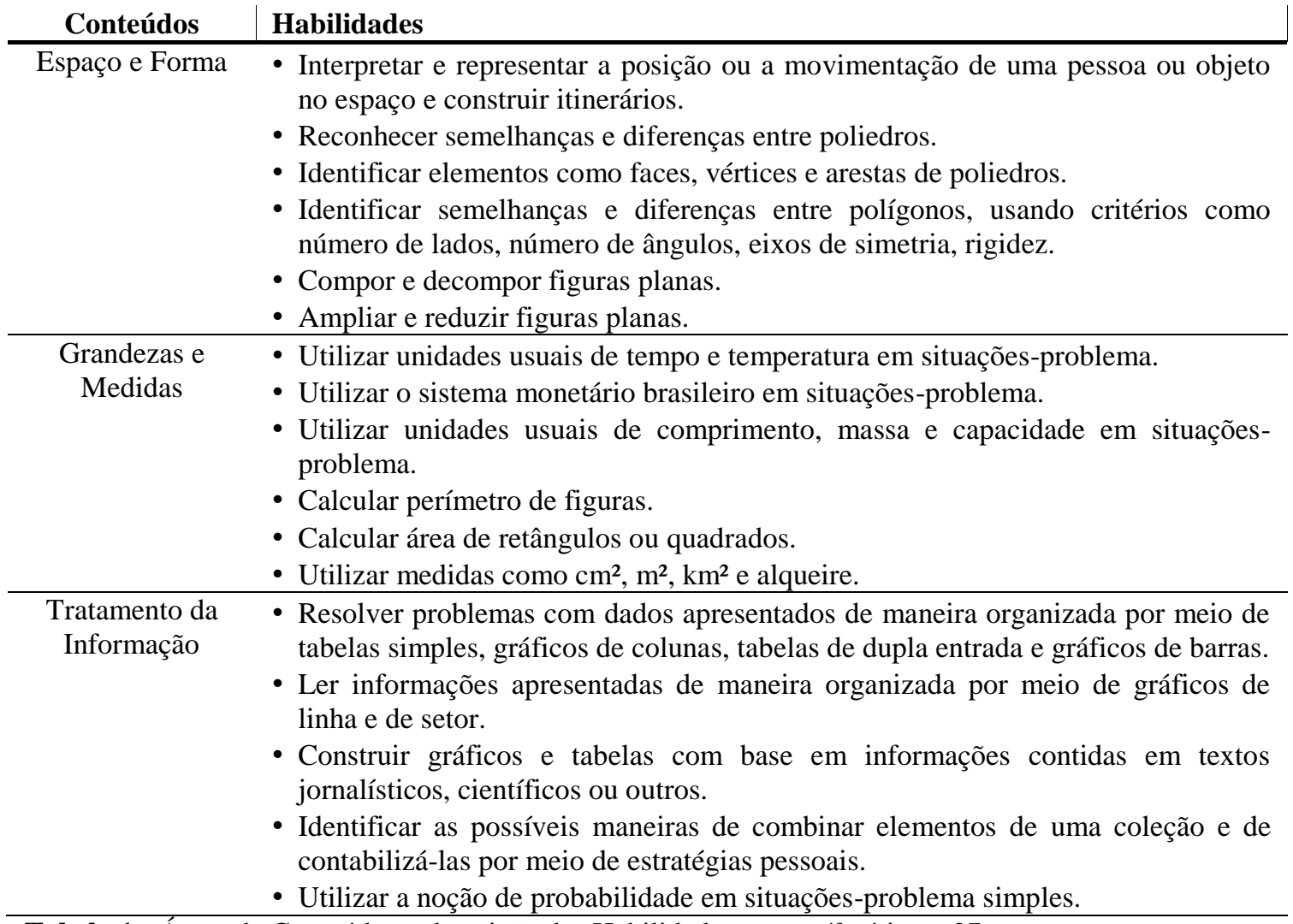

Tabela 1 - Áreas de Conteúdos e descrição das Habilidades para a $4^{\text {a }}$ série, p. 27.

\subsection{A Proposta Curricular do Ensino Fundamental - CICLO II}

A publicação da Proposta Curricular do Estado de São Paulo caracteriza a área curricular de Matemática, expõe os seus objetivos gerais, a organização curricular dos conteúdos e orientações didáticas.

Sobre a caracterização dos principais elementos da área curricular de Matemática para o Ensino Fundamental, a Proposta Curricular do Estado de São Paulo considera, apesar de utilizarem terminologia diferente, a exploração dos campos da Aritmética e da Álgebra, a sistematização do campo da Geometria, a interligação entre os campos da Aritmética, da Álgebra e da Geometria e as noções de Estatística, Probabilidade e Combinatória como possibilidade de coleta, organização, manipulação e interpretação de variáveis relacionadas a fenômenos da realidade.

Ainda de acordo com a publicação mencionada anteriormente, as atividades de Matemática devem priorizar práticas de resolução de problemas que envolvam contagem, medida, significados das operações e seleção de procedimentos, localização em espaços e identificação de formas, comparação e ordenação de quantidades, interpretação e expressão de 
resultados, escrita e leitura de símbolos. Além disso, devem proporcionar condições para o desenvolvimento de habilidades de análise e de reflexão sobre os múltiplos determinantes das relações de significado, bem como a expressão e a construção de instrumentos que ampliem, de modo progressivo, a competência de abstração, expressão e argumentação dos alunos.

De modo consistente com as caracterizações dos elementos desta área curricular no âmbito do Ensino Fundamental, na Proposta Curricular do Estado de São Paulo, a Matemática encontra-se articulada em quatro eixos: a) Números; b) Espaço e Forma; c) Grandezas e Medidas e d) Tratamento da Informação (GOVERNO DO ESTADO DE SÃO PAULO, 2008c). A Proposta Curricular do Estado de São Paulo propõem ainda para o Ciclo II, três pares complementares, que constituem três eixos norteadores da ação educacional: a) o eixo expressão/compreensão, b) o eixo $\operatorname{argumentação/decisão~} \quad$ e c) $\quad$ o eixo contextualização/abstração.

\begin{tabular}{|c|c|}
\hline Eixo & Descrição do Eixo \\
\hline Números & $\begin{array}{l}\text { - Ampliação da idéia do campo numérico por meio de situações significativas que } \\
\text { problematizem essa necessidade. } \\
\text { - Ao final do Ensino Fundamental, espera-se que o aluno seja capaz de reconhecer } \\
\text { e de operar no campo numérico real, o que constituirá a porta de entrada para } \\
\text { aprofundamentos, sistematizações e estabelecimento de novas relações no Ensino } \\
\text { Médio. }\end{array}$ \\
\hline $\begin{array}{c}\text { Geometria } \\
\text { (Espaço e Forma) }\end{array}$ & $\begin{array}{l}\text { - Reconhecimento, representação e classificação das formas planas e espaciais, } \\
\text { preferencialmente trabalhando em contextos concretos com as crianças de } 5^{\mathrm{a}} \text {. a } \\
6^{\mathrm{a}} \text {. séries, e com ênfase na articulação do raciocínio lógico-dedutivo nas } 7^{\mathrm{a}} \text {. e } 8^{\mathrm{a}} \text {. } \\
\text { séries. }\end{array}$ \\
\hline $\begin{array}{l}\text { Grandezas e } \\
\text { Medidas }\end{array}$ & $\begin{array}{l}\text { - É um eixo que pode favorecer a interdisciplinariedade, uma vez que sua ligação } \\
\text { com os eixos dos Números e da Geometria acontece quase que naturalmente, } \\
\text { tanto para o Ensino Fundamental, quanto para o Ensino Médio. }\end{array}$ \\
\hline $\begin{array}{l}\text { Tratamento da } \\
\text { Informação }\end{array}$ & $\begin{array}{l}\text { - Este campo estende-se para além das fronteiras da organização e análise de } \\
\text { dados. }\end{array}$ \\
\hline
\end{tabular}

Tabela 2 - Eixos temáticos da Proposta Curricular do Estado de São Paulo p. 45-47

Para os quatro primeiros eixos mencionados são preconizados, respectivamente: a) cálculo escrito e mental; b) exploração do espaço e percepção de formas descritiva e analiticamente; c) utilização de grandezas físicas, identificação de atributos a serem medidos e interpretação do significado da medida; e d) leitura, discussão e resolução de problemas. Os três eixos complementares mencionados pela Proposta Curricular do Estado de São Paulo contemplam comportamentos compatíveis com: a) o uso das diversas linguagens, b) análise e articulação das informações e relações disponíveis nos conteúdos curriculares e c) contextualização dos conteúdos estudados na realidade imediata e a capacidade de consideração de novas perspectivas, de novas potencialidades que ainda não existem. 
$\mathrm{Na}$ Proposta Curricular do Estado, ainda que não se encontre menção a modalidade de conteúdo curricular procedimental fazendo uso dessa terminologia, são especificadas competências a serem aprendidas que deverão ser expressas pelos alunos sob a forma de capacidades. Capacidades que são descritas como ações a serem desempenhadas pelos alunos.

\subsection{O Sistema de Avaliação do Rendimento Escolar do Estado De São Paulo - SARESP}

Considerando os aspectos estruturais mencionados anteriormente na descrição das propostas curriculares, com relativo consenso admite-se a necessidade de mecanismos que permitam avaliar o aproveitamento dos estudantes durante este período de escolaridade obrigatória. Sendo assim, as diretrizes curriculares da Secretaria de Estado de Educação de São Paulo orientam também as bases que compõem o Sistema de Avaliação do Rendimento Escolar do Estado de São Paulo - SARESP (2009a), cujo objetivo é avaliar o aproveitamento dos alunos durante o Ensino Fundamental e Médio. Ainda fazendo referência ao resultado obtido a partir do desempenho do aluno, o Estado realiza análises estatísticas que fornecem informações e elementos que o possibilita analisar o atual sistema de ensino e, também, pensar em reformas ou novas políticas educacionais.

Portanto, o SARESP tem a característica de ser uma avaliação externa e pode ser compreendido, na perspectiva da Análise do Comportamento, como um sistema que prevê consequências diferenciais (acerto ou erro), não imediatas (remotas) e arbitrárias (não naturais). Em outros termos, o SARESP encontra-se inserido numa política de educação institucional e de Estado, sendo sua característica principal atribuir uma nota, ou seja, reforço arranjado, não-natural (reforçadores "espúrios"; cf. Skinner, 1968; p.83) às manifestações comportamentais de habilidades e competências.

A primeira implantação do SARESP ocorreu em 1996 e, com exceção dos anos de 1999 e 2006, esta avaliação externa foi aplicada anualmente em milhares de estudantes da rede pública estadual. Os resultados obtidos sobre o rendimento escolar destes alunos, apresentados também sob a forma de estudos estatísticos e pedagógicos estão à disposição de educadores e gestores de ensino, bem como a todos os interessados.

Em tese, ao promover o acesso aos resultados, o Estado espera subsidiar, principalmente, professores no desenvolvimento do planejamento de ações que possibilitem a superação dos problemas identificados de aprendizagem e em novas proposições de situações de ensino, buscando estratégias pedagógicas mais eficazes com base no conhecimento do 
perfil dos alunos. Já para a gestão são reservadas as ações analíticas sobre os resultados que vão permitir apoiar as escolas e os professores com recursos, serviços e orientações.

Estima-se que se o SARESP for visto à luz de uma perspectiva somente política, social e econômica, levando-se em conta apenas seus resultados, esta avaliação não representará medidas, nem tampouco apresentará condições para que o professor disponha de boas contingências educacionais.

Porém, encarando o documento do SARESP numa perspectiva educacional e, entendendo que nessa perspectiva a descrição das habilidades e das competências delineia repertórios comportamentais válidos e importantes para inclusão do aluno ao modelo de sociedade em que vivemos atualmente, a análise de seus resultados, não se limitando a uma valorização do rendimento e desempenho do aluno, poderá fornecer ao professor contingências a partir das quais, ele poderá realizar uma programação ou planejamento de suas aulas, de forma a oportunizar condições e consequências adequadas às necessidades de seus alunos.

Ao longo de sua historia de aplicações, o SARESP vem sofrendo modificações, seguindo metodologias distintas, e, a partir de 2007, encontra-se nas mesmas métricas do exame nacional para a Educação Básica do Brasil - SAEB, atualmente Prova Brasil, o que tornam os resultados obtidos pelos alunos do Estado de São Paulo passíveis de comparação entre as duas avaliações externas.

As provas do SARESP são elaboradas com base em matrizes de referencias, ou seja, tabelas que especificam habilidades e competências a serem observadas nos alunos em cada série e disciplina. Pode-se entender, portanto, que esta proposta, embasada pela Proposta Curricular do Estado de São Paulo: Matemática, considera competências como referência de aprendizagem

\footnotetext{
Competências caracterizam modos de ser, raciocinar e interagir que podem ser depreendidos das ações e das tomadas de decisão em contextos de problemas, tarefas ou atividades. Graças a elas podemos inferir se a escola como instituição está cumprindo bem o papel que se espera dela no mundo de hoje. (GOVERNO DO ESTADO DE SÃO PAULO, 2008c; p. 14)
}

Assim, na dimensão discursiva, garante-se ao professor o direito de fomentar ações (desempenhos) distintas nos alunos sob a justificativa de que tais ações ou desempenhos são expressões de capacidades e/ou competências estimadas como imprescindíveis para determinada etapa (ou ciclo, ou ano, ou série) da escolarização. 
Para a Análise do Comportamento, uma habilidade ou competência é identificada mediante a um comportamento expresso (ação) por um aluno. Sendo assim, a caracterização diante das Matrizes do SARESP das aulas ministradas, realizadas neste trabalho, levou em conta o comportamento operante do aluno, que segundo SKINNER (2003, 64-75), são aqueles comportamentos que modificam o ambiente e essas modificações no ambiente levam, por sua vez, a modificações no comportamento subseqüente.

Admite-se que competências e capacidades são termos tratados com distinções em literatura específica e discutir a natureza dessas distinções certamente escapa ao escopo desta investigação. O interesse é mostrar que na Proposta Curricular do Estado de São Paulo, as intenções educativas devem expressar metas que, por sua vez, devem se referir à aquisições cujo desenvolvimento se pretende promover mediante a escolaridade. O documento oficial advoga uma interpretação epistemológica avessa àquela preconizada pelo Behaviorismo Radical e pela Análise do Comportamento, segundo a qual competências e capacidades são de natureza distinta daquilo que se admite se constituir em suas respectivas medidas, a saber, ações e desempenhos. Nestes termos, determinadas ações e desempenhos são estimados como medidas comportamentais de competências e capacidades, considerados como construtos comportamentais.

No documento do SARESP, são três Grupos de Competências que estruturam o sistema de avaliação. Em linguagem comportamental, podemos nos arriscar a dizer que estes grupos descrevem um repertório ou um conjunto de repertórios que conferem ao aluno um modo de se comportar, diante dos conteúdos previstos.

Os grupos descritos são:

(1) Grupo I: Competência para observar: este grupo descreve as habilidades, relacionadas aos conteúdos de Matemática, que fornecem as primeiras condições para que um aluno resolva um problema ou uma questão. Sendo assim, as habilidades são descritas utilizando termos, tais como: observar, identificar, descrever, localizar, diferenciar ou discriminar, constatar, reconhecer, indicar, apontar. Portanto, espera-se avaliar medidas fundamentais sobre a interpretação do aluno a respeito das informações que definem uma tarefa, um exercício ou questão.

(2) Grupo II: Competência para realizar: este grupo descreve habilidades que os alunos devem demonstrar para realizar procedimentos que os levem a tomadas de decisões. Os termos utilizados na descrição das habilidades são: classificar, seriar, ordenar, conservar, compor, decompor, fazer 
antecipações, entre outras, cujo objetivo é avaliar a capacidade do aluno em realizar um procedimento em resposta a uma questão;

(3) Grupo III: Competência para compreender: este grupo descreve habilidades, que envolvem pensamento proposicional ou combinatório, sendo os Grupos anteriormente descritos considerados meios pelos quais os alunos poderão desenvolver operações mentais mais complexas. Os termos utilizados neste grupo para descrever as habilidades são analisar fatos, acontecimentos ou possibilidades na perspectiva de seus princípios, padrões e valores, aplicar relações conhecidas em situações novas, entre outras.

Para cada Grupo de Competência, são descritas as habilidades e competências a serem avaliadas em termos de desempenho dos alunos nas avaliações. As Tabelas 4 e 5 mostram um recorte da descrição dessas habilidades e competências, distribuídas por Eixos Temáticos e Grupos de Competência.

Competências de Área 1: Desenvolver o raciocínio quantitativo e o pensamento funcional, isto é, o pensamento em termos de relações e a variedade de suas representações, incluindo as simbólicas, as algébricas, as gráficas, as tabulares e as geométricas.

\begin{tabular}{|c|c|c|c|}
\hline \multirow[b]{2}{*}{$\begin{array}{c}\text { Objetos do } \\
\text { conhecimento }\end{array}$} & \multicolumn{3}{|c|}{ COMPETÊNCIAS DO SUJEITO } \\
\hline & $\begin{array}{c}\text { Grupo I } \\
\text { Competências para } \\
\text { observar }\end{array}$ & $\begin{array}{c}\text { Grupo II } \\
\text { Competências para } \\
\text { realizar }\end{array}$ & $\begin{array}{c}\text { Grupo III } \\
\text { Competências para } \\
\text { compreender }\end{array}$ \\
\hline \multirow[t]{2}{*}{$\begin{array}{l}\text { Tema } 1- \\
\text { Números, } \\
\text { operações, } \\
\text { funções }\end{array}$} & $\begin{array}{l}\text { H1. Identificar a } \\
\text { localização de números } \\
\text { naturais na reta } \\
\text { numérica. }\end{array}$ & $\begin{array}{l}\text { H2. Relacionar a } \\
\text { escrita numérica às } \\
\text { regras do sistema } \\
\text { posicional de } \\
\text { numeração. }\end{array}$ & $\begin{array}{l}\text { H12. Resolver problemas que } \\
\text { envolvam a adição ou a subtração, } \\
\text { em situações relacionadas aos seus } \\
\text { diversos significados. }\end{array}$ \\
\hline & $\begin{array}{l}\text { H3. Escrever um } \\
\text { número natural pela } \\
\text { sua decomposição em } \\
\text { forma polinomial. }\end{array}$ & $\begin{array}{l}\text { H10. Calcular o } \\
\text { resultado de uma } \\
\text { adição ou subtração de } \\
\text { números naturais. }\end{array}$ & $\begin{array}{l}\text { H13. Resolver problemas que } \\
\text { envolvam a multiplicação e a } \\
\text { divisão, especialmente em } \\
\text { situações relacionadas à } \\
\text { comparação entre razões e à } \\
\text { configuração retangular. }\end{array}$ \\
\hline
\end{tabular}

Tabela 3 - Matriz de referência com a descrição das competências e habilidades para a Área 1 de Matemática da 4a. Série do Ensino Fundamental, p. 66.

Cabe ressaltar que os temas parametrizados pelo SARESP diferem dos temas das expectativas de aprendizagem para o Ensino Fundamental - Clico I, sendo considerados 
quatro temas (1) Números, operações, funções; (2) Espaço e forma; (3) Grandezas e medidas; (4) Tratamento da informação. De acordo com as expectativas de aprendizagem, os temas Números e Operações são desdobrados em conjuntos de habilidades distintos.

Competências de Área 1: Desenvolver o raciocínio quantitativo e o pensamento funcional, isto é, o pensamento em termos de relações e a variedade de suas representações, incluindo as simbólicas, as algébricas, as gráficas, as tabulares e as geométricas. Aplicar expressões analíticas para modelar e resolver problemas.

\begin{tabular}{|c|c|c|c|}
\hline \multirow[b]{2}{*}{$\begin{array}{l}\text { Objetos do } \\
\text { conhecimento }\end{array}$} & \multicolumn{3}{|c|}{ COMPETÊNCIAS DO SUJEITO } \\
\hline & $\begin{array}{c}\text { Grupo I } \\
\text { Competências para } \\
\text { observar }\end{array}$ & $\begin{array}{c}\text { Grupo II } \\
\text { Competências para } \\
\text { realizar }\end{array}$ & $\begin{array}{c}\text { Grupo III } \\
\text { Competências para } \\
\text { compreender }\end{array}$ \\
\hline $\begin{array}{c}\text { Tema 1: } \\
\text { Números, } \\
\text { operações, } \\
\text { funções } \\
\text { (racionais / } \\
\text { potenciação, } \\
\text { números reais, } \\
\text { expressões } \\
\text { algébricas, } \\
\text { equações, } \\
\text { gráficos, gráficos } \\
\text { cartesianos, } \\
\text { equações de } 2^{\circ} \\
\text { grau, funções) }\end{array}$ & $\begin{array}{l}\text { H2. Identificar fração } \\
\text { como representação que } \\
\text { pode estar associada a } \\
\text { diferentes significados. }\end{array}$ & $\begin{array}{l}\text { H10. Efetuar cálculos que } \\
\text { envolvam operações com } \\
\text { números racionais (adição, } \\
\text { subtração, multiplicação, } \\
\text { divisão, potenciação - } \\
\text { expoentes inteiros e } \\
\text { radiciação). }\end{array}$ & $\begin{array}{l}\text { H15. Resolver problemas } \\
\text { com números racionais } \\
\text { que envolvam as } \\
\text { operações (adição, } \\
\text { subtração, multiplicação, } \\
\text { divisão, potenciação e } \\
\text { radiciação). } \\
\text { H16. Resolver problemas } \\
\text { que envolvam } \\
\text { porcentagem. }\end{array}$ \\
\hline
\end{tabular}

Tabela 4 - Matriz de referência com a descrição das competências e habilidades para a Área 1 de Matemática da 8a. Série do Ensino Fundamental, p. 78.

Os resultados obtidos por meio das avaliações do SARESP são analisados em três níveis distintos: na própria escola, nas Diretorias de Ensino e em nível central. Para se chegar a esses resultados e, como consequência às análises, o SARESP tem dois instrumentos avaliativos, sendo um questionário do aluno, com o objetivo de obter um perfil familiar, acerca dos professores, da gestão da escola e, também, sobre sua participação nos projetos desenvolvidos junto à Secretaria de Estado da Educação, para verificar as possíveis interferências desses fatores na aprendizagem. O outro instrumento consiste na aplicação de provas para medir o desempenho dos alunos em leitura e 
escrita, uma delas constituída por 30 questões objetivas, tanto no Ensino Fundamental, quanto no Ensino Médio. A outra prova apresenta um tema para redação do tipo narrativo-descritivo para o Ensino Fundamental e do tipo dissertativo-argumentativo para o Ensino Médio. (SAZDJIAN, 2007; p. 2)

Antes de uma aplicação e da correção das provas do SARESP, os professores responsáveis participam de uma formação, realizada em nível central, regional e local, com atividades presenciais e videoconferências (à distância). Além disso, esses professores recebem manuais de orientação sobre os procedimentos adotados em cada etapa do SARESP.

Ainda segundo o documento do SARESP, o professor do ano subseqüente tem acesso ao desempenho de seus novos alunos para, assim, conhecer as precondições que os alunos irão apresentar em sua nova turma. Para isso, todo início de ano que segue a aplicação do SARESP, no período de planejamento escolar, os professores, juntamente com o coordenador pedagógico, são orientados a analisarem o desempenho dos alunos em cada questão, verificando em quais habilidades a média dos alunos ficou abaixo do índice esperado de desempenho. Com essa análise, é possível discutir estratégias a serem desenvolvidas e como conteúdos podem ser trabalhados.

Cabe mencionar, de particular relevância para a presente dissertação, que o SARESP fornece quantificação para os desempenhos que, supostamente, se constituiriam em medida comportamental de habilidades e competências.

No âmbito do modelo teórico da Análise do Comportamento caberia indagar se as contingencias planejadas pelo professor para o ensino de determinado conteúdo da área de Matemática, durante o ano letivo, teriam estabelecido os repertórios exigidos pelas questões de avaliação do SARESP. Em outros termos, os repertórios exigidos pelas questões do SARESP foram estabelecidos, durante o ano letivo, pelas práticas de ensino e de avaliação dispostas pelo professor? Com relação a determinados conteúdos da área de Matemática, quais são as práticas de ensino que poderiam sustentar correspondência com as competências e habilidades requeridas?

Nesta dissertação há uma descrição de estratégias metodológicas que objetivavam caracterizar as ações da professora em sala de aula e estima a extensão na qual tais práticas se constituíram em condição fornecedora de desempenhos dos alunos consistentes com as habilidades e competências preconizadas. 


\section{MÉTODO DA PESQUISA}

\subsection{Participantes}

Neste estudo serão analisadas aulas ministradas por dois professores - PMA e PRA - que lecionam no Ensino Fundamental, em escolas da rede pública estadual de uma cidade do interior do estado de São Paulo.

PRA é formado em Licenciatura Plena em Matemática, com especialização em Prática de Ensino e ministra aulas de matemática em uma oitava série. Atua há 14 anos no ensino particular, há 2 anos no ensino público estadual com vínculo efetivo e na escola em que ocorreu a coleta de dados há um ano e meio.

PMA possui curso de magistério e habilitação em Pedagogia e ministra aulas em uma quarta série. Atua há 23 anos no magistério público, mas não possui vínculo efetivo: inicialmente atuou como "eventual" e, em seguida, como "estável” há um ano e meio na escola onde foi realizada a coleta de dados.

\subsection{Material}

Para fins de análise, foram utilizados os registros em vídeos efetuados por SPARVOLI (2008). As condições de registro em vídeo foram aprovadas pelo Comitê de Ética em Pesquisa da Faculdade de Ciências da UNESP/Bauru, com a autorização da coordenação pedagógica das escolas onde ocorreram as sessões de coleta de dados e também com a autorização escrita dos pais e/ou responsáveis pelos alunos.

Os registros em vídeos foram efetuados entre os anos de 2006 e 2007, consecutivamente em uma estrutura de Unidades Didáticas tanto para PRA, quanto para PMA. O termo Unidade Didática compreende um conjunto de aulas ministradas de modo consecutivo, sem interrupção, sobre um determinado tema escolhido pelo professor.

Todas as sessões de filmagem foram realizadas nas próprias escolas, em horário regular das aulas de matemática ministradas por PMA e PRA.

Para a tabulação dos registros em vídeo, em termos dos conteúdos ministrados pelos professores e das respectivas competências envolvidas, serão utilizadas tabelas explicitadas a seguir, na seção de Procedimento. 


\subsection{Procedimentos de Descrição e Análise}

Os vídeos utilizados para análise nesta pesquisa consistiram em duas Unidades Didáticas ministradas por cada professora participante e gravadas por Sparvoli (2008). Os seguintes temas foram escolhidos pelas próprias professoras e representam cada unidade didática:

(1) Para PMA, os temas escolhidos foram: Leitura e Construção de Tabelas e Leitura e Construção de Gráficos, que representam, respectivamente, Unidade Didática 01 (UD - 01) e Unidade Didática 02 (UD - 02).

(2) Para PRA, os temas escolhidos foram: Teorema de Pitágoras: demonstração e interpretação e Aplicação do Teorema de Pitágoras, que representam, respectivamente, Unidade Didática 01 (UD - 01) e Unidade Didática 02 (UD - 02).

Os procedimentos de análise dos registros em vídeo foram subdivididos em quatro etapas, descritas a seguir.

\subsubsection{Etapa 1 - Caracterização das habilidades diante das práticas de ensino de professores}

Na Etapa 1, diante da exibição contínua e ininterrupta dos vídeos, a pesquisadora designou habilidades que possivelmente se constituiriam em objeto de ensino das práticas emitidas por cada professora. Assim, de acordo com ao tema selecionado e considerando o registro sequêncial das aulas, a pesquisadora designou, com base nas Matrizes de Referências do SARESP (GOVERNO DO ESTADO DE SÃO PAULO, 2009a), as habilidades, dentro dos respectivos grupos de competências que poderiam sustentar correspondências com as práticas de ensino das professoras.

Para auxiliar essa análise, as habilidades identificadas foram arranjadas em uma tabela, como o modelo abaixo mostra. 


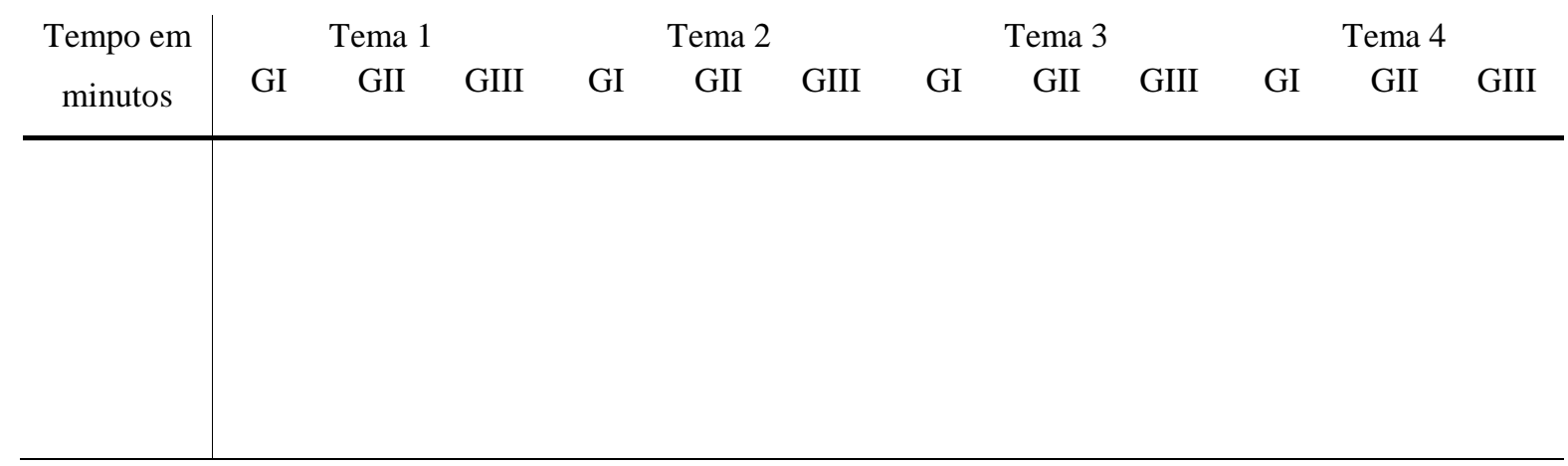

Tabela 5 - Instrumento 1 de análise: Tabela de Caracterização das Habilidades Associadas

A tabela 5 ilustra o instrumento utilizado na designação de habilidades correspondentes aos respectivos temas considerando intervalos, em minutos, do transcurso das aulas gravadas. Foram inseridas, no instrumento, cinco colunas. Na primeira coluna, a pesquisadora registrou o tempo, em minutos, no qual os desempenhos dos alunos possivelmente sustentaram correspondência com medidas comportamentais das habilidades vinculadas com os respectivos temas: Tema 1, Tema 2, Tema 3 ou Tema 4, conforme a Matriz do SARESP (GOVERNO DO ESTADO DE SÃO PAULO, 2009a). As habilidades foram inseridas nas próximas 4 colunas, que delimitam os 4 principais temas da disciplina de Matemática: Tema 1 - Números, operações, funções; Tema 2: Espaço e Forma; Tema 3: Grandezas e medidas; Tema 4: Tratamento da Informação. Para cada coluna de tema, foram inseridas mais 3 colunas, que localizam a habilidade associada dentro de cada um dos Grupos de Competência: GI - Competências para Observar; GII - Competências para Realizar; GIII Competências para Compreender.

O objetivo deste instrumento é permitir a caracterização dos desempenhos dos alunos nas aulas registradas em vídeos, utilizando como referência a Matriz do SARESP, o que poderá nos fornecer pistas sobre as práticas de ensino vinculadas com a produção das habilidades preconizadas.

A descrição e a caracterização das interações entre as condições de ensino e de oralização dispostas pelas professoras e as medidas de desempenho dos alunos em contato com tais condições, objetivavam ampliar a compreensão sobre as estratégias utilizadas por cada professora que se mostravam compatíveis com o desenvolvimento das competências propostas nos documentos oficiais considerados. Em acréscimo, investigou-se se a análise de tais tabulações poderia subsidiar a proposição de recursos didáticos igualmente vinculados com a obtenção de tais habilidades e competências. 


\subsubsection{Etapa 2 - Descrição das habilidades a partir das interações registradas e Análise das interações correspondentes às habilidades vinculadas}

Na Etapa 2, a pesquisadora elaborou um novo instrumento que deveria permitir o registro e a descrição das relações de interação entre as ações dos professores e dos alunos ocorridas durante as aulas registradas em vídeo, considerando a designação de habilidades realizada na etapa anterior. Cada interação foi descrita em tabelas, às quais chamamos de Unidades de Análises ou Hipóteses, cujo modelo foi exemplificado a seguir.

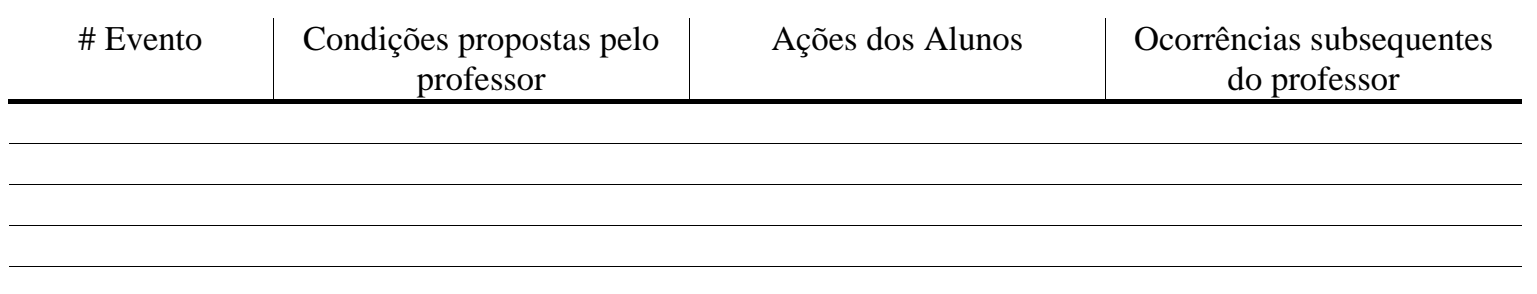

Tabela 6 - Instrumento 2 - Tabela Unidades de Análises ou Hipóteses

A tabela de Unidades de Análises ou Hipóteses foi criada com os objetivos de descrever e analisar, posteriormente, as possíveis relações de contingências de reforçamento ocorridas nas aulas registradas. Com isso, foi possível sistematizar a descrição das principais características das condições antecedentes, representadas pela coluna intitulada Condições propostas pelo professor, as Ações dos alunos em resposta a essas condições e as Ocorrências subsequentes do professor às respostas emitidas pelos alunos com a intenção de identificar como o professor desenvolve suas aulas de forma a possibilitar o desenvolvimento de determinadas habilidades e competências elencadas pela avaliação do SARESP, ou seja, as colunas Condições propostas pelo professor e Ocorrências subsequentes do professor sempre descrevem as ações do professor em relação à resposta dos alunos.

Esse instrumento foi utilizado para descrever as interações ocorridas entre os professores e os alunos sobre cada habilidade designada na Etapa 1. Com isso, é possível sistematizar uma sequência instrucional desempenhada pelos professores e, desta forma, conhecer as condições anteriores e posteriores às ações dos alunos, que caracterizam o contexto no qual medidas comportamentais das habilidades designadas pela pesquisadora foram emitidas. 


\subsubsection{Etapa 3 - Síntese das análises obtidas na Etapa 2}

Nesta etapa foi efetuada uma síntese com as principais características observadas na Etapa anterior. Essa síntese priorizou as frequências de ocorrências de repertórios das professoras e dos alunos nos registros efetuados.

\subsection{Procedimentos de Propostas para recursos didáticos informatizados}

Para o delineamento das propostas dos recursos didáticos informatizados foram percorridas três etapas, que visavam atingir o segundo objetivo que norteia esta pesquisa. Sendo assim, este procedimento foi estabelecido pela pesquisadora mediante aos resultados das análises obtidos nos procedimentos de descrição e análise realizados anteriormente. Diante da caracterização e das análises da prática de ensino das professoras, apoiadas na teoria analítico-comportamental, constatou-se ser necessário verificar possíveis subsídios para delineamentos de recursos didáticos informatizados, em termo de práticas de ensino e de material de apoio didático.

Esses recursos didáticos informatizados têm como objetivo prioritário fornecer aos professores novos meios para realizar as atividades com os alunos, de forma a prover instrumentos que viabilizem, dentro da estratégia de ensino elaborada pelo professor, o desenvolvimento dos repertórios de comportamentos esperados sob as perspectivas das habilidades e competências parametrizadas no Sistema de Avaliação de Rendimento do Estado de São Paulo (SARESP).

Para esta proposição/delineamento, será necessário o cumprimento de novas etapas para o procedimento de pesquisa, que seguem abaixo descritas.

\subsubsection{Etapa 1 - Descrever a programação do ensino das Unidades Didáticas}

O delineamento do recurso didático informatizado, neste trabalho, está intimamente relacionado às propostas de atividades elaboradas pelos professores, cujas Unidades Didáticas foram analisadas, ou seja, existe uma relação de dependência, que deverá ser justificada por estas análises. 
Sendo assim, cabe, antes de iniciar o delineamento de recursos, a descrição compreendida pela exibição dos vídeos da programação do plano de ensino utilizada pelas professoras em suas aulas como orientação para estabelecer a sequência dos conteúdos a serem tratados nos recursos.

Para isso, foram elencadas em tópicos, as principais ações efetuadas pelas professoras, como foram estabelecidas as condições de interação entre aluno e professor e os recursos utilizados (lousa, livro didático, caderno, materiais que o professor entregou para os alunos). O objetivo desta etapa é sistematizar o programa utilizado pelas professoras na busca de definir algumas variáveis observadas a partir da análise das interações. Essas variáveis serão utilizadas e descritas na Etapa 3, quando o protocolo do recurso for exposto.

\subsubsection{Etapa 2 - Elencar as características das práticas de ensino analisadas}

O delineamento dos recursos didáticos informatizados apresenta-se como consequência das análises realizadas sobre as Unidades Didáticas, as principais características identificadas das práticas de ensino para que o recurso seja elaborado de forma que possibilite o apoio das interações entre professor e aluno que poderiam garantir condições para a emissão de repertórios consistentes com as habilidades priorizadas.

\subsubsection{Etapa 3 - Delinear o recurso didático}

Mediante aos dados observados e descritos nas Etapas 1 e 2 deste procedimento, o protocolo abaixo será registrado com informações sobre o recurso a ser delineado. O modelo a seguir contém campos de dados, cujo objetivo é construir um plano de ensino.

Para Skinner (1968, p. 47), o primeiro passo para essa construção é definir o campo, ou seja, o tema do programa. Em seguida, elencar "termos técnicos, fatos, leis, princípios e casos". Planejando todos esses elementos de forma linear, onde um próximo passo apenas será acessado, se o anterior for respondido de maneira correta e a cada passo concluído pelo aluno, o recurso deverá emitir uma tela sobre o seu desempenho. 
Dados do Recurso didático informatizado

\begin{tabular}{l}
\hline Série/Ano: \\
\hline Disciplina: \\
\hline Título: \\
\hline Tema principal: \\
\hline Conteúdos ou conceitos envolvidos: \\
\hline Habilidades envolvidas: \\
\hline Objetivos do Recurso \\
\hline Conhecimentos prévios \\
\hline Tempo previsto: \\
\hline Tecnologias utilizadas: \\
\hline Resumo do Recurso:
\end{tabular}

Tabela 7 - Dados do Recurso didático informatizado

O preenchimento dos dados acima favorecerá o delineamento do recurso, de forma que seu planejamento "vá direto ao ponto" (Skinner, 1968; p. 47), ou seja, mantendo-se dentro das expectativas de aprendizagem. Ao preencher a tabela acima, o recurso será delineado em termos de telas e atividades.

Para este delineamento, a pesquisadora, tela a tela, deverá "desenhar" um roteiro que exemplifique as atividades, bem como, as situações de aprendizagem e os elementos que devem compor cada tela, como por exemplo, botões, links, imagens. Esse instrumento é conhecido como storyboard (roteiro) e determina quais serão os passos a serem percorridos pelo aluno para realizar uma atividade e como os conteúdos previstos na tabela de dados do recurso didático informatizado serão abordados.

Como parâmetro para determinar a abordagem dos conteúdos e os caminhos a serem percorridos pelo aluno, serão utilizadas as análises elaboradas nas Etapas 2 e 3 deste trabalho. 


\section{RESULTADOS: DESCRIÇÃO E ANÁLISE}

Nesta seção, os resultados obtidos com cada professora em cada unidade didática ministrada serão apresentados separadamente com o intuito de garantir o acesso mais organizado e direto com as propriedades relevantes das medidas obtidas.

\subsection{Resultados de PMA - UD - 01}

A Unidade Didática - 01 de PMA tem como tema principal a Leitura e Construção de Tabelas. Para desenvolver este tema, PMA propõe a seguinte atividade: "Vamos ler uma tabela usada por médicos, que indica quanto o menino e a menina costumam ter em média, de estatura (altura) e peso, de acordo com a idade."

\subsubsection{Etapa 1 - Caracterização das habilidades diante das práticas de ensino de professores}

\begin{tabular}{|c|c|c|c|c|c|c|c|c|c|c|c|c|}
\hline \multirow{2}{*}{$\begin{array}{c}\text { Tempo em } \\
\text { minutos }\end{array}$} & \multicolumn{3}{|c|}{ Tema 1} & \multicolumn{3}{|c|}{ Tema 2} & \multicolumn{3}{|c|}{ Tema 3} & \multicolumn{3}{|c|}{ Tema 4} \\
\hline & GI & GII & GIII & GI & GII & GIII & GI & GII & GIII & GI & GII & GIII \\
\hline $8 ’ 30$ & & & & & & & $\mathrm{H} 22$ & & & & & \\
\hline $10^{\prime} 55$ & & & & & & & & & & & & $\mathrm{H} 29$ \\
\hline $12^{\prime} 38$ & & & & & & & $\mathrm{H} 22$ & & & & & \\
\hline $12^{\prime} 48$ & & & & & & & & $\mathrm{H} 23$ & & & & \\
\hline $15 ' 26$ & & H10 & & & & & & & & & & \\
\hline $15^{\prime} 35$ & & & & & & & $\mathrm{H} 22$ & & & & & \\
\hline $16^{\prime} 08$ & & & & & & & & $\mathrm{H} 23$ & & & & \\
\hline $17^{\prime} 15$ & & & & & & & & & & & & $\mathrm{H} 29$ \\
\hline
\end{tabular}

Tabela 8 - Tabela de Caracterização das Habilidades - UD 01 - PMA

Ao assistir a Unidade Didática 01 de PMA, a pesquisadora vinculou as práticas de ensino e de avaliação observadas nas gravações com as habilidades inseridas na tabela acima. As habilidades relacionadas estão da seguinte forma descritas no SARESP (GOVERNO DO ESTADO DE SÃO PAULO, 2009a): 
- H10. Calcular o resultado de uma adição ou subtração de números naturais.

- H22. Reconhecer unidades de medida usuais de comprimento, de superfície, de capacidade, de tempo e de temperatura.

- H23. Estimar a medida de grandezas utilizando unidades de medida convencionais ou não.

- H29. Ler e/ou interpretar informações e dados apresentados em tabelas e construir tabelas.

Posta a tabela anterior, a seguir, foram descritas e analisadas as interações registradas considerando cada uma das habilidades vinculadas, levando em consideração a sequência na qual as interações ocorreram. No transcurso da aula, as exposições orais dos alunos e dos professores envolvidos nos episódios de gravação considerados foram destacadas em itálico.

\subsubsection{Etapa 2 - Descrição das habilidades a partir das interações registradas e Análise das interações correspondentes às habilidades vinculadas}

Habilidade: H22 - Reconhecer unidades de medida usuais de comprimento, de superfície, de capacidade, de tempo e de temperatura.

\begin{tabular}{|c|c|c|c|}
\hline \# Evento & $\begin{array}{c}\text { Condições propostas por } \\
\text { PMA }\end{array}$ & Ações dos Alunos & $\begin{array}{c}\text { Ocorrências subsequentes } \\
\text { do professor }\end{array}$ \\
\hline 1 & $\begin{array}{l}\text { PMA escreve na lousa a } \\
\text { atividade a ser } \\
\text { desenvolvida em aula e } \\
\text { distribui aos alunos uma } \\
\text { folha que contém duas } \\
\text { tabelas sobre o mesmo } \\
\text { tema: uma tabela com o } \\
\text { peso e a estatura de } \\
\text { meninos distribuídos por } \\
\text { idade e uma tabela com as } \\
\text { mesmas informações sobre } \\
\text { as meninas. PMA diz: } \\
\text { Quando nós vamos no } \\
\text { médico, desde que somos } \\
\text { pequenininhos, toda vez } \\
\text { que vai no médico, o que o }\end{array}$ & $\begin{array}{l}\text { Vários alunos respondem } \\
\text { oralmente: pesa e mede. }\end{array}$ & $\begin{array}{l}\text { Primeira coisa antes de } \\
\text { fazer o histórico médico } \\
\text {..., já pesa e mede a } \\
\text { criancinha. Por que será } \\
\text { que é feito isso? }\end{array}$ \\
\hline
\end{tabular}




\begin{tabular}{|c|c|c|c|}
\hline \# Evento & $\begin{array}{c}\text { Condições propostas por } \\
\text { PMA }\end{array}$ & Ações dos Alunos & $\begin{array}{c}\text { Ocorrências subsequentes } \\
\text { do professor }\end{array}$ \\
\hline & \multicolumn{3}{|l|}{ médico faz? } \\
\hline \multirow[t]{4}{*}{2} & \multirow{4}{*}{$\begin{array}{l}\text { Por que será que é feito } \\
\text { isso? }\end{array}$} & Um aluno responde & \multirow{4}{*}{$\begin{array}{l}\text { Você acha que é isso?, } \\
\text { PMA diz para o aluno e } \\
\text { continua: Mas não quando } \\
\text { ela nasce, quando ela } \\
\text { nasce também. Mas, } \\
\text { depois, toda vez que ela } \\
\text { vai no médico, ele pesa e } \\
\text { mede. }\end{array}$} \\
\hline & & $\begin{array}{l}\text { oralmente: Para ver } \\
\text { quantos ela nasce. }\end{array}$ & \\
\hline & & & \\
\hline & & $\begin{array}{l}\text { PMA interrompe o aluno } \\
\text { que começa a falar e dá } \\
\text { atenção a outro aluno, que } \\
\text { fala baixo o que achava } \\
\text { (como falou muito baixo, } \\
\text { não foi possível entender o } \\
\text { áudio). }\end{array}$ & \\
\hline 3 & $\begin{array}{l}\text { Mas, depois, toda vez que } \\
\text { ela vai no médico, ele pesa } \\
\text { e mede. }\end{array}$ & $\begin{array}{l}\text { Um aluno responde } \\
\text { oralmente: Para ver } a \ldots \\
\text { (áudio com problemas). }\end{array}$ & $\begin{array}{l}\text { PMA fala então: para ver } \\
\text { o peso e ... }\end{array}$ \\
\hline 4 & $\begin{array}{l}\text { PMA fala então: para ver } \\
\text { o peso e ... }\end{array}$ & $\begin{array}{l}\mathrm{E} \text { os alunos respondem } \\
\text { oralmente: } e \text { o tamanho! }\end{array}$ & $\begin{array}{l}\text { PMA: Ah lá! Para ver se a } \\
\text { criança ou ela está acima } \\
\text { do peso ou se ela está } \\
\text { abaixo do peso. }\end{array}$ \\
\hline 5 & $\begin{array}{l}\text { PMA: Ah lá! Para ver se a } \\
\text { criança está acima do } \\
\text { peso ou abaixo do peso. }\end{array}$ & $\begin{array}{l}\text { Um aluno responde } \\
\text { oralmente: ou se ela está } \\
\text { normal. }\end{array}$ & $\begin{array}{l}\text { PMA: Ou, se não, a } \\
\text { estatura: o tamanho dela, } \\
\text { se ela tem o tamanho } \\
\text { normal. }\end{array}$ \\
\hline 6 & $\begin{array}{l}\text { PMA: Ou, se não, a } \\
\text { estatura: o tamanho dela, } \\
\text { se ela tem o tamanho } \\
\text { normal. }\end{array}$ & $\begin{array}{l}\text { Um aluno responde } \\
\text { oralmente: saiu no jornal } \\
\text { que nasceu um menino lá } \\
\text { no México ... (áudio com } \\
\text { problemas). }\end{array}$ & $\begin{array}{l}\text { PMA: E agora tem } \\
\text { aparecido muito no jornal } \\
\text { criança que tem nascido } \\
\text { com muito mais peso, do } \\
\text { que é o geralmente ... } \\
\text { Então, aparece no jornal } \\
\text { criança que nasceu com } 5 \\
\text { quilos ou, às vezes, mais } \\
\text { de } 5 \text { quilos. E parece } \\
\text { também, criancinha, que } \\
\text { nasce o quê? }\end{array}$ \\
\hline 7 & $\begin{array}{l}\text { PMA: E parece também, } \\
\text { criancinha, que nasce o } \\
\text { que? }\end{array}$ & $\begin{array}{l}\text { Um aluno responde } \\
\text { oralmente: Magrina. }\end{array}$ & $\begin{array}{l}\text { PMA: Tem criança que } \\
\text { nasce bem pequininha, que } \\
\text { nasce, às vezes, que nem } \\
\text { pesa } 1 \text { quilo. Então, essa } \\
\text { tabela aqui é usada para } \\
\text { quê? O que leva em } \\
\text { conta? O que será que } \\
\text { está predominando na } \\
\text { tabela? O médico olha o } \\
\text { quê? }\end{array}$ \\
\hline
\end{tabular}

Tabela 9 - Tabela Unidades de Análises ou Hipóteses - H22 - PMA - UD - 01 


\section{Descrição e análise dos eventos registrados}

No evento \#1, PMA entregou, inicialmente, tabelas impressas aos alunos. Essas tabelas contêm colunas que identificam: idade, peso e estatura de meninos e meninas, em tabelas separadas. O modelo das tabelas entregues por PMA está inserido a seguir:

\begin{tabular}{|c|c|c|c|c|c|}
\multirow{2}{*}{ Idade } & \multicolumn{2}{|c|}{ Meninos } & \multirow{2}{*}{ Idade } & \multicolumn{2}{c|}{ Meninas } \\
\cline { 2 - 3 } \cline { 5 - 6 } & Peso $(\mathbf{K g})$ & Estatura $(\mathbf{c m})$ & & Peso $\mathbf{K g})$ & Estatura (cm) \\
\hline 6 & 21 & 116 & 6 & 19 & 115 \\
\hline 7 & 22 & 122 & 7 & 22 & 120 \\
\hline 8 & 25 & 127 & 8 & 25 & 126 \\
\hline 9 & 28 & 132 & 9 & 28 & 132 \\
\hline 10 & 31 & 137 & 10 & 33 & 138 \\
\hline 11 & 35 & 143 & 11 & 37 & 145 \\
\hline 12 & 40 & 150 & 12 & 41 & 151 \\
\hline 13 & 45 & 156 & 13 & 45 & 157 \\
\hline 14 & 51 & 163 & 14 & 50 & 160 \\
\hline
\end{tabular}

Tabela 10 - Modelo das Tabelas de Estatura e Peso de Meninas e Meninos - PMA - UD - 01

Ao entregar as tabelas, PMA, em sua ação subseqüente, explicita as unidades de medidas vinculadas às respostas dos alunos, ou seja, os temas peso e estatura são tratados em termos de ação do médico: pesa e mede.

No evento \#2, um aluno responde oralmente a questão de PMA, dizendo o seguinte: Para ver quantos ela nasce. Diante de uma questão colocada para a classe como um todo, sem designar um aluno específico, foram observadas várias respostas orais simultâneas produzindo uma situação de concorrência. PMA permaneceu em contato visual com um dos alunos que emitiu resposta oral para a sua indagação. Mesmo quando este último aluno finaliza sua fala, PMA dá sequência à sua aula, sem, contudo, expor para a sala a resposta emitida em voz baixa pelo aluno, tampouco sem explorar possíveis relações de controle de estímulo envolvidas nas respostas emitidas. Ainda neste segundo evento, os temas peso e estatura são tratados em termos de ação de um médico: pesa e mede.

No evento \#4, os alunos tentam responder oralmente sobre o mesmo assunto (pesa e mede), mas são interrompidos por PMA que começa a responder a questão levantada por ela no evento anterior, sendo que os alunos apenas complementam a resposta iniciada por PMA. Ao iniciar a resposta esperada dos alunos, PMA induz como eles devem complementá-la. Ainda neste evento, os temas peso e estatura são tratados em termos de ação do médico: pesa e mede. 
No evento \#5, PMA está oralmente descrevendo o por quê a tabela referida é utilizada por médicos. PMA utiliza uma prática de ensino centrada em seu comportamento verbal, mesmo assim, um aluno complementa, também de forma oral, o que PMA está explicando. Porém, ao dar continuidade à sua ação, PMA utiliza a fala do aluno para completar sua explicação, sem, contudo, voltar-se para o aluno e verificar o que ele entendeu como normal.

Nos próximos eventos, \#6 e \#7, um aluno interrompe a explicação de PMA, dizendo que leu em um jornal sobre o nascimento de uma criança com peso acima da média. PMA, então, aproveita o comentário do aluno e inicia uma nova explicação, dizendo que nos jornais é muito comum existir esse tipo de notícia e, dando continuidade, pergunta aos alunos de maneira geral, que além de crianças acima ou abaixo do peso, aparece também nos jornais que elas nascem o que? Um aluno responde de forma a continuar relacionando as informações ao peso da criança e diz: magrinha. PMA complementa a resposta oral do aluno, explicando que algumas crianças nascem bem pequenininhas e propõe novas indagações, fazendo com que os alunos voltem sua atenção às tabelas entregues no início da aula.

Em resumo, as várias tentativas orais dos alunos ocorreram diante de questões e de observações de PMA, também expostas oralmente. Embora tais interações evidenciem a participação dos alunos, as possíveis relações de contingências descritas mostram-se insuficientes para atestar se as tabelas e as interações estabelecem relações de controle sobre medidas comportamentais da $\mathrm{H} 22$.

A partir das ocorrências registradas para a caracterização da tabela 10 apresentada sobre a Habilidade H22, é possível perceber que diante de questões que exploram ou indagam dimensões diferentes das unidades de medida, foram produzidas respostas destituídas de função informativa sobre o reconhecimento de unidades de medidas pelos próprios alunos. Diante de tais respostas, foram registrados comentários de PMA nos quais ela menciona as unidades de medida, sem destacar o acréscimo que tais informações deveriam produzir nas respostas iniciais dos alunos.

Sendo assim, muito embora as interações entre PMA e os alunos priorizem a H22 do GI para o Tema 3, pode-se verificar que as condições (em particular, práticas educativas para explorar, induzir manifestações ou desenvolvimento dos repertórios relacionados com GI) proporcionadas por PMA parecem ter ocasionado medidas comportamentais distintas daquilo que poderia sustentar correspondências com a H22. Também pode percebe-se que as manifestações subsequentes às respostas dos alunos parecem carecer de função instrucional, que permitiria ampliar as possibilidades de aprimoramento das respostas, ou seja, carecem de 
esclarecimentos sobre as diferenças entre o que os alunos responderam e as respostas esperadas por PMA, sendo que também não há continuidade de um assunto iniciado anteriormente ou, se existe essa tentativa, as questões são elaboradas de maneira muito ampla e geral, não fornecendo pistas aos alunos sobre como e o quê analisar.

Habilidade: H29. Ler e/ou interpretar informações e dados apresentados em tabelas e construir tabelas.

\begin{tabular}{|c|c|c|c|}
\hline \# Evento & $\begin{array}{c}\text { Condições propostas por } \\
\text { PMA }\end{array}$ & Ações dos Alunos & $\begin{array}{c}\text { Ocorrências subsequentes } \\
\text { do professor }\end{array}$ \\
\hline 1 & $\begin{array}{l}\text { PMA: Então, essa tabela } \\
\text { aqui é usada para quê? O } \\
\text { que leva em conta? O que } \\
\text { será que está } \\
\text { predominando na tabela? } \\
\text { O médico olha o quê?? }\end{array}$ & $\begin{array}{l}\text { Alguns alunos respondem } \\
\text { oralmente: } a \text { idade. }\end{array}$ & $\begin{array}{l}\text { PMA: Pela idade da } \\
\text { criança, ele vai ver o } \\
\text { quanto que ele pesa e vai } \\
\text { vero quanto o quê? }\end{array}$ \\
\hline 2 & $\begin{array}{l}\text { PMA: Pela idade da } \\
\text { criança, ele vai ver o } \\
\text { quanto que ele pesa e vai } \\
\text { ver o quanto o quê?? }\end{array}$ & $\begin{array}{l}\text { Alguns alunos respondem } \\
\text { oralmente: mede. }\end{array}$ & $\begin{array}{l}\text { PMA: } O \text { das meninas e } \\
\text { dos meninos dá uma } \\
\text { olhadinha. Será que são } \\
\text { iguaiszinhos? }\end{array}$ \\
\hline 3 & $\begin{array}{l}\text { PMA: } O \text { das meninas e } \\
\text { dos meninos dá uma } \\
\text { olhadinha. Será que são } \\
\text { iguaiszinhos? }\end{array}$ & Os alunos respondem: não. & $\begin{array}{l}\text { PMA: Então tem } \\
\text { variações, tem idades que } \\
\text { até batem. Quem que sabe } \\
\text { ver aí uma idade que o } \\
\text { peso das duas ficou igual? }\end{array}$ \\
\hline 4 & $\begin{array}{l}\text { PMA: Então tem } \\
\text { variações, tem idades que } \\
\text { até batem. Quem que sabe } \\
\text { ver aí uma idade que o } \\
\text { peso das duas ficou igual? }\end{array}$ & $\begin{array}{l}\text { Alguns alunos respondem } \\
\text { oralmente: } 0,9,8,7 \text { anos. }\end{array}$ & $\begin{array}{l}\text { PMA: Aos } 8 \text { anos, as } \\
\text { meninas pesam } 25 \text { e os } \\
\text { meninos pesam } 25 \text {. As de } 9 \\
\text { também: } 28 \text { e 28. As de } 7 \\
\text { também. As de } 6 \text { anos tem } \\
\text { diferença. As meninas } \\
\text { pesam } 19 \text { e os meninos } \\
\text { vão pesar quanto? }\end{array}$ \\
\hline 5 & $\begin{array}{l}\text { PMA: As meninas pesam } \\
19 \text { e os meninos vão pesar } \\
\text { quanto? }\end{array}$ & $\begin{array}{l}\text { Alguns alunos respondem } \\
\text { oralmente: } 21 .\end{array}$ & $\begin{array}{l}\text { PMA: Agora, aqui na } \\
\text { estatura, o que é Estatura? }\end{array}$ \\
\hline 6 & $\begin{array}{l}\text { PMA: Agora, aqui na } \\
\text { estatura, o que é Estatura? }\end{array}$ & $\begin{array}{l}\text { Alguns alunos respondem } \\
\text { oralmente: Altura. }\end{array}$ & $\begin{array}{l}\text { PMA: Está na tabela } \\
\text { assim: que a medida está o } \\
\text { quê? }\end{array}$ \\
\hline
\end{tabular}

Tabela 11 - Tabela Unidades de Análises ou Hipóteses - H29 - PMA - UD - 01

\section{Descrição e análise dos eventos registrados}

Os alunos, no primeiro evento, respondem à PMA de forma a expressar a primeira informação disposta na tabela, que é a idade. A idade constitui a primeira coluna das tabelas 
entregues. Em consequência, PMA, sem fazer comentários sobre as respostas dos alunos, dá continuidade aos seus questionamentos. A questão elaborada por PMA acaba por interpretar os dados contidos na tabela.

No evento em sequência, \#2, os alunos respondem à PMA expressando oralmente o único dado que falta ser citado, que é a altura. PMA, neste momento, solicita que os alunos observem as informações contidas nas duas tabelas, alertando eles quanto à igualdade das informações entre meninos e meninos. PMA passa a colocar a análise para emissão de respostas de leitura da tabela a produção prévia das medidas consistentes com H22 de GI. A exploração, a estimulação, o enfoque de habilidades de grupos mais complexos (GIII), prescinde da manifestação de medidas de habilidade de grupos simples (GI).

Os questionamentos feitos por PMA como eventos subsequentes em \#2 induzem o aluno a responder exatamente o que ela previa, limitando, assim, outras possibilidades que dariam condições para que os alunos tivessem espaço para interpretar as informações contidas nas tabelas apresentadas.

Diante desta descrição, percebe-se que as respostas orais de leitura e/ou de interpretação de informações da tabela foram registradas diante de indagações nas quais PMA elaborou as análises comparativas (interpretações) entre as informações dispostas nas tabelas. São respostas de confirmação ou de acréscimo às análises de PMA; sendo que tais elaborações - efetuadas por PMA, poderiam ter se constituído em medidas da habilidade de GIII, que designam habilidade para compreender.

Embora se tratando, em tese, de uma habilidade de GIII, há intervenções de PMA nas quais a elaboração das análises e comparação entre medidas/informações são realizadas por PMA e solicita participação dos alunos na confirmação de tais análises.

PMA tem modo de estimular a ocorrência de habilidade de GIII no qual, aparentemente, parcela expressiva das medidas é emitida por PMA e não pelos alunos; sendo que as medidas produzidas pelos alunos adquirem uma função complementar. Portanto, pelas respostas emitidas pelos alunos, mediante aos estímulos de PMA, a aprendizagem das competências para compreender torna-se inconclusiva e evidenciam, de forma bastante frequente, o comportamento dos alunos em observarem apenas o dado solicitado, sem, contudo, percorrer as análises previamente realizadas por PMA, para chegar às conclusões cujas respostas seriam os dados expressos oralmente. 
Habilidade: H22 - Reconhecer unidades de medida usuais de comprimento, de superfície, de capacidade, de tempo e de temperatura.

\begin{tabular}{c|l|c|c} 
\# Evento & $\begin{array}{c}\text { Condições propostas por } \\
\text { PMA }\end{array}$ & Ações dos Alunos & $\begin{array}{c}\text { Ocorrências subsequentes } \\
\text { do professor }\end{array}$ \\
\hline 1 & PMA: Está na tabela Um aluno responde & PMA: Centímetro. Como \\
& $\begin{array}{c}\text { assim: que a medida estáo oralmente: 1 metro e 16. será que eu consigo } \\
\text { que? }\end{array}$ & Outro aluno: centímetros. & $\begin{array}{l}\text { transformar centímetros } \\
\text { em metros? Onde que } \\
\end{array}$ \\
& & & vemos um centímetro? \\
\hline
\end{tabular}

Tabela 12 - Tabela Unidades de Análises ou Hipóteses - H22 - PMA - UD - 01

\section{Descrição e análise dos eventos registrados}

PMA, então, inicia uma atividade para identificar a unidade de medida com a qual os dados da coluna Estatura foram inseridos na tabela. Dois alunos respondem à questão de PMA, de maneiras diferentes: o primeiro reconhece na tabela a unidade de medida centímetros $(\mathrm{cm})$ e o outro converte uma das medidas apresentadas em metros.

Neste registro, as respostas orais evidenciam o reconhecimento de unidade de medida, correspondente ao Grupo de Competência GI - Observar e a conversão da unidade apresentada na tabela, correspondente ao Grupo de Competência GII - Realizar diante da indagação direta e explícita de PMA. Mas, eventos subseqüentes exploram a ocorrência de outras habilidades (H23 - Estimar a medida de grandezas utilizando unidades de medida convencionais ou não) e não ressalta a correspondência entre a resposta emitida e a indagação inicialmente formulada. Direcionando sua prática desta forma, PMA prescinde de fornecer um feedback aos alunos que responderam a questão feita.

Quando as respostas definem as medidas comportamentais das habilidades de GI e GII, as ações subsequentes de PMA indagam sobre novas habilidades e não ressaltam correspondências entre as indagações iniciais que propiciariam a ocorrência das medidas comportamentais de GI. 
Habilidade: H23 - Estimar a medida de grandezas utilizando unidades de medida convencionais ou não.

\begin{tabular}{|c|c|c|c|}
\hline \# Evento & $\begin{array}{c}\text { Condições propostas por } \\
\text { PMA }\end{array}$ & Ações dos Alunos & $\begin{array}{c}\text { Ocorrências subsequentes } \\
\text { do professor }\end{array}$ \\
\hline 1 & $\begin{array}{l}\text { PMA: Centímetro. Como } \\
\text { será que eu consigo } \\
\text { transformar centímetros } \\
\text { em metros? Onde que } \\
\text { vemos um centímetro? }\end{array}$ & $\begin{array}{l}\text { Alguns alunos respondem } \\
\text { oralmente: Num metro. } \mathrm{Na} \\
\text { régua. }\end{array}$ & $\begin{array}{l}\text { PMA: Quanto que é } 1 \\
\text { centímetro? Geralmente, } \\
\text { onde vocês usam muito é a } \\
\text { régua. Pega a régua de } \\
\text { vocês. Essa régua de vocês } \\
\text { é de quantos centímetros? }\end{array}$ \\
\hline 2 & $\begin{array}{l}\text { PMA: Essa régua de vocês } \\
\text { é de quantos centímetros? }\end{array}$ & $\begin{array}{l}\text { Alguns alunos respondem } \\
\text { oralmente: } 50 \text { centímetros. } \\
\text { Eu tenho uma de } 20 \mathrm{~cm} \text {. } \\
30 \mathrm{~cm} \text {. }\end{array}$ & $\begin{array}{l}\text { PMA: A Dona X já } \\
\text { ensinou vocês a usarem a } \\
\text { régua. Não ensinou? Essa } \\
\text { partinha } \\
\text { pequenininha, o que é? } \\
\begin{array}{l}\text { Essas } \\
\text { pequenininhas. }\end{array}\end{array}$ \\
\hline 3 & $\begin{array}{l}\text { PMA: Essa partinha aqui } \\
\text { pequenininha, o que é? }\end{array}$ & $\begin{array}{l}\text { Alguns alunos respondem } \\
\text { oralmente: Centímetros. } \\
\text { Milímetros. }\end{array}$ & $\begin{array}{l}\text { PMA: Quantos } \\
\text { centímetros será que eu } \\
\text { preciso pegar para formar } \\
\text { um metro? }\end{array}$ \\
\hline 4 & $\begin{array}{l}\text { PMA: Quantos } \\
\text { centímetros será que eu } \\
\text { preciso pegar para formar } \\
\text { um metro? }\end{array}$ & $\begin{array}{l}\text { Alguns alunos respondem } \\
\text { oralmente: } 60, \quad 100 \\
\text { centímetros, } 1000,200 .\end{array}$ & $\begin{array}{l}\text { PMA: 100? Uma régua } \\
\text { mede quanto? }\end{array}$ \\
\hline 5 & $\begin{array}{l}\text { PMA: 100? Uma régua } \\
\text { mede quanto? }\end{array}$ & $\begin{array}{l}\text { Alguns alunos respondem } \\
\text { oralmente: } 30 . E u \text { tenho } \\
\text { uma de } 20 .\end{array}$ & $\begin{array}{l}\text { PMA: Pode pegar uma e } \\
\text { marcar. Se eu pegasse } \\
\text { uma régua, quanto que } \\
\text { tem aqui? }\end{array}$ \\
\hline 6 & $\begin{array}{l}\text { PMA: Pode pegar uma e } \\
\text { marcar. Se eu pegasse } \\
\text { uma régua, quanto que } \\
\text { tem aqui? }\end{array}$ & $\begin{array}{l}\text { Alguns alunos respondem } \\
\text { oralmente: } 1 \text { metro. } 30 \\
\text { centímetros }\end{array}$ & PMA: Deu um metro? \\
\hline 7 & PMA: Deu um metro? & $\begin{array}{l}\text { Alguns alunos respondem } \\
\text { oralmente: Não. }\end{array}$ & $\begin{array}{l}\text { PMA: Quanto que eu } \\
\text { tenho que pegar a mais? }\end{array}$ \\
\hline 8 & $\begin{array}{l}\text { PMA: Quanto que eu } \\
\text { tenho que pegar a mais? }\end{array}$ & $\begin{array}{l}\text { Alguns alunos respondem } \\
\text { oralmente: } 5 \mathrm{~cm} .200 \mathrm{~cm} \text {. } \\
\text { Mais 200. Mais duas } \\
\text { (réguas) e } 10 \mathrm{~cm} .\end{array}$ & $\begin{array}{l}\text { PMA: Então, vamos ver. } \\
\text { Se eu pegar mais } 30 \text {, } \\
\text { quanto que deu? }\end{array}$ \\
\hline 9 & $\begin{array}{l}\text { PMA: Então, vamos ver. } \\
\text { Se eu pegar mais } 30 \text {, } \\
\text { quanto que deu? }\end{array}$ & $\begin{array}{l}\text { Alguns alunos respondem } \\
\text { oralmente: Não deu um } \\
\text { metro ainda. Deu } 60 \\
\text { centímetros. }\end{array}$ & $\begin{array}{l}\text { PMA: Mais 30, quanto } \\
\text { que deu? }\end{array}$ \\
\hline 10 & $\begin{array}{l}\text { PMA: Mais 30, quanto } \\
\text { que deu? }\end{array}$ & $\begin{array}{l}\text { Alguns alunos respondem } \\
\text { oralmente: } 60 \text { centímetros. }\end{array}$ & PMA: Deu 1 metro? \\
\hline 11 & PMA: Deu 1 metro? & $\begin{array}{l}\text { Alguns alunos respondem } \\
\text { oralmente: Não. }\end{array}$ & $\begin{array}{l}\text { PMA: Quanto que eи pego } \\
\text { mais? }\end{array}$ \\
\hline 12 & $\begin{array}{l}\text { PMA: Quanto que eи pego } \\
\text { mais? }\end{array}$ & $\begin{array}{l}\text { Alguns alunos respondem } \\
\text { oralmente: } 1 \text { régua. } 30\end{array}$ & $\begin{array}{l}\text { PMA: Aluna } X \text { falou } 40 . \\
\text { Na régua tem } 40 ?\end{array}$ \\
\hline
\end{tabular}




\begin{tabular}{c|l|l|l} 
\# Evento & $\begin{array}{c}\text { Condições propostas por } \\
\text { PMA }\end{array}$ & \multicolumn{1}{|c|}{ Ações dos Alunos } & $\begin{array}{c}\text { Ocorrências subsequentes } \\
\text { do professor }\end{array}$ \\
\hline & & $\begin{array}{l}\text { centímetros. 40. Mais } 1 \\
\text { régua e 10 centímetros. }\end{array}$ \\
\hline 13 & PMA: Na régua tem 40? & $\begin{array}{l}\text { Alguns alunos respondem } \\
\text { oralmente: Não. }\end{array}$ & PMA: Quanto que tem? \\
\hline 14 & PMA: Quanto que tem? & $\begin{array}{l}\text { Alguns alunos respondem } \\
\text { oralmente: } 30 .\end{array}$ & $\begin{array}{l}\text { PMA: Então vamos pegar } \\
\text { mais 30. }\end{array}$ \\
\hline
\end{tabular}

\section{Descrição e análise dos eventos registrados}

No evento \#1, PMA inicia sua questão para fornecer um contexto ou uma justificativa sobre a questão elaborada e continua sua sessão de indagações com o seguinte: Onde vemos um centímetro?. Os alunos respondem a questão de maneira diversa. Porém, nenhuma das respostas é comentada por PMA. Em seguida, PMA utiliza uma régua como modelo e continua com suas indagações.

No evento \#2, PMA indaga a turma sobre quantos centímetros compõem a régua de cada um. Várias foram as respostas manifestadas. De acordo com as respostas, os alunos tinham réguas de comprimentos diferentes. A sequência de PMA foi relatar que os alunos já haviam aprendido a usar a régua, sem, contudo, comentar as respostas emitidas por eles.

No evento \#3, PMA, oralmente pergunta o que é a parte pequenininha e solicita a eles que digam o que significava aquela parte. Os alunos respondem de várias maneiras: centímetros, milímetros. PMA, ao escutar as respostas, fala: Isso e continua perguntando quantos centímetros seriam necessários para formar um metro. Mas, pelo registro de vídeo efetuado, a forma como a questão da parte pequenininha foi elaborada poderia gerar dúvidas sobre o que deveriam responder, já que não fica claro na passagem à qual divisão das medidas na régua PMA fazia referência.

No evento \#4, assumindo que os alunos compreenderam como observar na régua a medida de 1 centímetro, PMA solicita a eles que falem quantos centímetros são necessários para formar 1 metro. As respostas são diversas, algumas acompanhadas pela unidade de medida (centímetros), outras com ausência dela. Além disso, os valores referidos também foram destoantes: 60, 100 centímetros, 1000, 200. PMA não comenta as respostas mencionadas pelos alunos e não investiga como ou por quê eles chegaram a tais valores.

No evento \#5, ao perceber as respostas dos alunos, PMA volta a falar sobre o comprimento da régua e solicita que os alunos falem novamente o comprimento das réguas. 
Nesta observação, percebe-se que PMA pergunta sobre o comprimento da régua como se existisse apenas um único comprimento de 30 centímetros e isso pode ficar mais evidente a partir do próximo evento.

A partir do evento \#6, PMA utiliza como modelo uma régua de $30 \mathrm{~cm}$ para fazer somas sucessivas e, assim, formar 1 metro. Neste evento especificamente, PMA solicita aos alunos que marcassem, pelo que foi possível observar, o comprimento de 30 centímetros e também marcou o mesmo comprimento na lousa. Em subsequência, \#7, PMA pergunta novamente se o que foi marcado resultava em 1 metro. Para alguns alunos sim, para outros, não.

Diante da resposta não (\#8), PMA pergunta quantos centímetros a mais seriam necessários serem somados aos 30 centímetros, já obtidos. As respostas são diversas: $5 \mathrm{~cm}$, $200 \mathrm{~cm}$, mais 200, mais duas réguas e $10 \mathrm{~cm}$. Cabe a observação aqui, que PMA não levou em consideração que alguns alunos manifestaram, em eventos anteriores, ter réguas de outros comprimentos e não há menção, por parte de PMA, sobre o valor obtido até então.

PMA (\#9) induz os alunos a somarem ao valor anterior $(30 \mathrm{~cm})$ mais $30 \mathrm{~cm} \mathrm{e}$ pergunta qual o valor que obtiveram até então, marcando na lousa $30 \mathrm{~cm}$ em sequência à primeira marcação. Houve respostas expressas, como: Não deu um metro ainda e alguns alunos responderam $60 \mathrm{~cm}$. No evento \#10, PMA repete a mesma pergunta, para obter a mesma resposta: $60 \mathrm{~cm}$ (PMA não adiciona mais $30 \mathrm{~cm}$ aos $60 \mathrm{~cm}$ ). Em seguida (\#11), pergunta novamente aos alunos se obtiveram a medida de 1 metro. A resposta dos alunos foi não.

Nos próximos registros, \#12, \#13 e \#14, PMA pergunta novamente quanto ainda seria necessário adicionar à medida já obtida para formar 1 metro. Um dos alunos responde: 40 centímetros. PMA utiliza-se desta resposta, mas não comenta as demais, perguntando se na régua tem 40 centímetros. Os alunos respondem não. E PMA volta a perguntar qual o comprimento de uma régua. Os alunos respondem: 30.

Diante de distintas respostas ou medidas das estimativas, as práticas educativas concentraram ênfase em impor resolução com base no modelo nas medidas definidas por PMA, em restritas explorações das razões ou fatores que justificavam a proposição de respostas distintas das previstas.

Nas medidas de estimativa de GII, posicionamentos de PMA subseqüentes às participações dos alunos ignoram explorar as fontes ou as razões vinculados com a produção de respostas distintas das previstas. 
Habilidade: H10. Calcular o resultado de uma adição ou subtração de números naturais.

\begin{tabular}{|c|c|c|c|}
\hline \# Evento & $\begin{array}{c}\text { Condições propostas por } \\
\text { PMA }\end{array}$ & Ações dos Alunos & $\begin{array}{c}\text { Ocorrências subsequentes } \\
\text { do professor }\end{array}$ \\
\hline \multirow[t]{2}{*}{1} & PMA: $30+30 ?$ & $\begin{array}{ll}\text { Alunos } & \text { respondem } \\
\text { oralmente: } 60 . & \end{array}$ & PMA: $60+30 ?$ \\
\hline & PMA: $60+30 ?$ & $\begin{array}{ll}\text { Alunos } & \text { respondem } \\
\text { oralmente: } 90 . & \end{array}$ & PMA: 90 é um metro? \\
\hline
\end{tabular}

Tabela 14 - Tabela Unidades de Análises ou Hipóteses - H10 - PMA - UD - 01

\section{Descrição e análise dos eventos registrados}

Em sequência à atividade de calcular a medida de 1 metro, utilizando uma régua de $30 \mathrm{~cm}$, PMA realiza este evento de cálculo de adição, junto aos alunos, iniciando a sequência de adição novamente. Os alunos responderam os valores resultantes das adições citadas por PMA corretamente.

As respostas orais que expressam medidas de cálculo de GII são efetuadas com valores numéricos de parcelas informadas por PMA, ou seja, a resposta oral expressa em cálculo genérico, não necessariamente está vinculada com a compreensão das relações entre o cálculo e suas origens ou justificativas dentro do conteúdo estudado. Sendo assim, PMA estimula a manifestação de medidas comportamentais de GII, sem, contudo, vincular os cálculos (dimensões dos conteúdos; por exemplo, valores das parcelas) com dimensões do conteúdo em estudo.

Habilidade: H22. Reconhecer unidades de medida usuais de comprimento, de superfície, de capacidade, de tempo e de temperatura.

\begin{tabular}{|c|c|c|c|}
\hline \# Evento & $\begin{array}{c}\text { Condições propostas por } \\
\text { PMA }\end{array}$ & Ações dos Alunos & $\begin{array}{c}\text { Ocorrências subsequentes } \\
\text { do professor }\end{array}$ \\
\hline 1 & PMA: 90 é um metro? & $\begin{array}{l}\text { Alunos respondem } \\
\text { oralmente: Não. }\end{array}$ & $\begin{array}{l}\text { PMA: Quanto falta, } \\
\text { então? }\end{array}$ \\
\hline 2 & $\begin{array}{l}\text { PMA: Quanto falta, } \\
\text { então? }\end{array}$ & \begin{tabular}{llr} 
Alunos & \multicolumn{2}{c}{ respondem } \\
oralmente: & mais $\quad 10$ \\
centímetros. & &
\end{tabular} & $\begin{array}{l}\text { PMA: } \quad \text { Mais } \\
\text { centímetros. Então, isso } \\
\text { aqui é 1 metro. Então, eu } \\
\text { posso por } 1 \text { metro ou o } \\
\text { que? }\end{array}$ \\
\hline 3 & $\begin{array}{l}\text { PMA: Então, isso aqui (na } \\
\text { lousa, PMA desenha uma } \\
\text { reta) é } 1 \text { metro. Então, eu }\end{array}$ & $\begin{array}{l}\text { Alunos } \\
\text { oralmente: } \\
\text { centímetros }\end{array}$ & $\begin{array}{l}\text { PMA: Então, na tabela } \\
\text { está em forma de } \\
\text { centímetros. Olha aí no }\end{array}$ \\
\hline
\end{tabular}




\begin{tabular}{ll}
\hline posso por l metro ou o & primeiro das meninas está \\
que? & $115 \mathrm{~cm}$ [PMA solicita que \\
& os alunos olhem a primeira \\
& linha da coluna Estatura \\
& referente às meninas da \\
& tabela entregue \\
& inicialmente]. Quanto em \\
& metros isso significa? \\
\hline
\end{tabular}

Tabela 15 - Tabela Unidades de Análises ou Hipóteses - H22 - PMA - UD - 01

\section{Descrição e análise dos eventos registrados}

Após a atividade de adição, em que obtiveram o valor de $90 \mathrm{~cm}$. PMA (evento \#1) questiona os alunos se $90 \mathrm{~cm}$ é um metro. A resposta dos alunos foi não e complementaram a questão seguinte (evento \#2) dizendo que faltava $10 \mathrm{~cm}$ para completar um metro.

No último evento, PMA escreve 1 metro na lousa e pergunta para os alunos sobre qual outra maneira poderia expressar a mesma medida. Eles respondem: 100 centímetros. Como sequência desta atividade, PMA volta a observar as tabelas entregues.

As respostas orais dos alunos emitiram reconhecimento de unidades de medidas, estas foram expressas diante de indagação diretivas ou explícitas que solicitaram quantificação de medidas. A manifestação subseqüente de PMA não explora a compreensão de um número maior de alunos, sobre os raciocínios (variáveis de controle) possivelmente relacionados com a emissão das respostas pelos alunos acima explicitados.

Diante das respostas corretas, PMA prescinde de explorar possíveis relações de controle, ou seja, quais seriam os fatores ou variáveis que determinaram as respostas previstas.

Habilidade: H23. Estimar a medida de grandezas utilizando unidades de medida convencionais ou não.

\begin{tabular}{|c|c|c|c|}
\hline \# Evento & $\begin{array}{c}\text { Condições propostas por } \\
\text { PMA }\end{array}$ & Ações dos Alunos & $\begin{array}{l}\text { Ocorrências subsequentes } \\
\text { do professor }\end{array}$ \\
\hline 1 & $\begin{array}{l}\text { PMA diz: Então, na tabela } \\
\text { está em forma de } \\
\text { centímetros. Olha aí no } \\
\text { primeiro das meninas está } \\
115 \mathrm{~cm} \text {. Quanto em metros } \\
\text { isso significa? }\end{array}$ & $\begin{array}{l}\text { Um aluno respondeu: } 1 \\
\text { metro e } 15 \text { centímetros. }\end{array}$ & $\begin{array}{l}\text { PMA diz: Um metro } e \\
\text { quinze centímetros. } \\
\text { Um aluno interroimpe } \\
\text { PMA e diz que só cresceu } \\
5 \mathrm{~cm} \text { em um ano. }\end{array}$ \\
\hline 2 & $\begin{array}{l}\text { PMA diz: você acha } \\
\text { pouco? E continua: O que } \\
\text { acontece? Tem idade que }\end{array}$ & $\begin{array}{l}\text { Vários alunos respondem: } \\
\text { 160. } 3 \text { centímetros. }\end{array}$ & $\begin{array}{l}\text { PMA diz: } 3 \mathrm{~cm} \text {. Depois, } \\
\text { quando chega lá pelos } 15 \text {, } \\
16 \text { e } 17 \text { é quando a }\end{array}$ \\
\hline
\end{tabular}




\begin{tabular}{|c|c|c|c|}
\hline \# Evento & $\begin{array}{c}\text { Condições propostas por } \\
\text { PMA }\end{array}$ & Ações dos Alunos & $\begin{array}{l}\text { Ocorrências subsequentes } \\
\text { do professor }\end{array}$ \\
\hline & $\begin{array}{l}\text { crescemos menos e idade } \\
\text { que crescemos mais. Olha } \\
\text { de } 13 \text { para } 14 \text { anos. } \\
\text { Quantos centimetros } \\
\text { cresceu? }\end{array}$ & & $\begin{array}{l}\text { criança cresce mais. } \\
\text { Então, aqui nós temos } \\
\text { duas tabelas. Será que nós } \\
\text { poderíamos formar uma } \\
\text { tabela só? }\end{array}$ \\
\hline
\end{tabular}

Tabela 16 - Tabela Unidades de Análises ou Hipóteses - H23 - PMA - UD - 01

\section{Descrição e análise dos eventos registrados}

Ao voltar a falar sobre a tabela, PMA lembra os alunos que na tabela as estaturas estão no formato de $\mathrm{cm}$, ainda que PMA não tenha expressado a palavra estatura, havia apenas uma coluna na qual a unidade de medida $\mathrm{cm}$ estava incluída nas duas tabelas da atividade. Em seguida, pergunta aos alunos quanto $115 \mathrm{~cm}$ equivalem em metros. Um aluno responde 1 metro e $15 \mathrm{~cm}$.

PMA, então, diz que existem idades nas quais crescemos mais e outras menos e, em seguida, solicita aos alunos que observem as idades 13 e 14 anos e pergunta qual a diferença entre as estaturas registradas na tabela das meninas. Um aluno respondem 160 (que representa a estatura total de uma das idades) e outro responde $3 \mathrm{~cm}$. PMA repete $3 \mathrm{~cm}$ e diz que quando a criança chega às idades entre 15 e 17 anos é que crescem mais. Neste ponto, PMA já começa a fazer uma análise dos dados contidos na tabela, sem, contudo, criar condições para que os alunos realizem tal atividade. Ao dizer isso, PMA inicia um novo questionamento.

Os alunos emitem respostas orais de estimativas para indagações objetivas de PMA. Em relação aos posicionamentos (práticas) de PMA subseqüentes a tais respostas dos alunos, caberia destacar dois aspectos:

(1) Induzidas ou motivadas pela indagação de PMA ocorreram duas respostas, sendo que nos comentários subseqüentes de PMA ignorou a resposta incorreta, prescindindo de qualquer exploração sobre possíveis influencias de determinantes para tal resposta (distinta da prevista);

(2) PMA elabora novas interpretações sobre dados das tabelas. Este tipo de comportamento (a) limita a elaboração de interpretações pelos próprios alunos; (b) mostra-se inconclusivo quanto à função de produzir condições adequadas para as quais os próprios alunos poderiam elabor/fornecer a interpretação sobre os dados das tabelas. 
Habilidade: H29. Ler e/ou interpretar informações e dados apresentados em tabelas e construir tabelas.

\begin{tabular}{|c|c|c|c|}
\hline \# Evento & $\begin{array}{c}\text { Condições propostas por } \\
\text { PMA }\end{array}$ & Ações dos Alunos & $\begin{array}{l}\text { Ocorrências subsequentes } \\
\text { do professor }\end{array}$ \\
\hline 1 & $\begin{array}{l}\text { PMA diz: Então, aqui nós } \\
\text { temos duas tabelas. Será } \\
\text { que nós poderíamos } \\
\text { formar uma tabela só? }\end{array}$ & $\begin{array}{l}\text { Vários alunos respondem: } \\
\text { Não. Dá. }\end{array}$ & $\begin{array}{l}\text { PMA diz: Como eu faria } \\
\text { isso? }\end{array}$ \\
\hline 2 & $\begin{array}{l}\text { PMA diz: Como eu faria } \\
\text { isso? }\end{array}$ & $\begin{array}{l}\text { Vários alunos respondem: } \\
\text { Cortar no meio. Colocar a } \\
\text { tabela das meninas } \\
\text { embaixo da tabela dos } \\
\text { meninos. }\end{array}$ & $\begin{array}{l}\text { PMA diz: Um aluno diz } \\
\text { para colocar uma tabela } \\
\text { embaixo da outra. Alguém } \\
\text { tem uma outra idéia? }\end{array}$ \\
\hline 3 & $\begin{array}{l}\text { PMA diz: Um aluno diz } \\
\text { para colocar uma tabela } \\
\text { embaixo da outra. Alguém } \\
\text { tem uma outra idéia? }\end{array}$ & $\begin{array}{l}\text { Um aluno responde: } \\
\text { Colocar a tabela dos } \\
\text { meninos embaixo } \\
\text { tabela das meninas. }\end{array}$ & $\begin{array}{l}\text { PMA diz: Sem colocar } \\
\text { embaixo. }\end{array}$ \\
\hline 4 & $\begin{array}{l}\text { PMA diz: Sem colocar } \\
\text { embaixo. }\end{array}$ & $\begin{array}{l}\text { Um aluno responde: } \\
\text { Misturando. }\end{array}$ & $\begin{array}{l}\text { PMA diz: Misturando de } \\
\text { que jeito? }\end{array}$ \\
\hline 5 & $\begin{array}{l}\text { PMA diz: Misturando de } \\
\text { que jeito? }\end{array}$ & $\begin{array}{l}\text { Vários alunos respondem: } \\
\text { Aí coloca o peso dos } \\
\text { meninos no peso das } \\
\text { meninas. }\end{array}$ & $\begin{array}{l}\text { PMA diz: Ele falou para } \\
\text { misturar os meninos com } \\
\text { as meninas. Alguém tem } \\
\text { uma outra idéia? }\end{array}$ \\
\hline 6 & $\begin{array}{l}\text { PMA diz: Ele falou para } \\
\text { misturar os meninos com } \\
\text { as meninas. Alguém tem } \\
\text { uma outra idéia? }\end{array}$ & $\begin{array}{l}\text { Vários alunos respondem: } \\
\text { Juntar os dois. }\end{array}$ & $\begin{array}{l}\text { PMA diz: Ao juntar os } \\
\text { dois, fazer de que jeito? }\end{array}$ \\
\hline 7 & $\begin{array}{l}\text { PMA diz: Ao juntar os } \\
\text { dois, fazer de que jeito? }\end{array}$ & $\begin{array}{l}\text { Vários alunos respondem: } \\
\text { Tira um. Colocar do lado } \\
\text { [O aluno não explica sua } \\
\text { ideia. Mas, o que se } \\
\text { entende é colocar uma } \\
\text { tabela ao lado da outra]. }\end{array}$ & $\begin{array}{l}\text { PMA diz: A aluna X falou } \\
\text { para tirar do lado. Alguém } \\
\text { tem outra idéia? Que } \\
\text { outro jeito poderia fazer? } \\
\text { Existe um outro jeito? }\end{array}$ \\
\hline 8 & $\begin{array}{l}\text { PMA diz: Que outro jeito } \\
\text { poderia fazer? Existe um } \\
\text { outro jeito? }\end{array}$ & $\begin{array}{l}\text { Vários alunos respondem: } \\
\text { Tira um. Em Cima. }\end{array}$ & $\begin{array}{l}\text { PMA diz: Agora eu vou } \\
\text { fazer uma pergunta. Para } \\
\text { eu comparar os meninos } \\
\text { com as meninas, é melhor } \\
\text { colocar em cima/embaixo } \\
\text { ou do lado? }\end{array}$ \\
\hline 9 & $\begin{array}{l}\text { PMA diz: Para eu } \\
\text { comparar os meninos com } \\
\text { as meninas, é melhor } \\
\text { colocar em cima/embaixo } \\
\text { ou do lado? }\end{array}$ & $\begin{array}{l}\text { Um aluno responde: } D o \\
\text { lado. }\end{array}$ & $\begin{array}{l}\text { PMA diz: Por que do } \\
\text { lado? }\end{array}$ \\
\hline 10 & $\begin{array}{l}\text { PMA diz: Por que do } \\
\text { lado? }\end{array}$ & $\begin{array}{l}\text { Um aluno responde: } \\
\text { Porque sim! } \\
\text { Outros alunos dizem que é } \\
\text { em cima e outros que é do } \\
\text { lado, mas não respondem a } \\
\text { questão de PMA. }\end{array}$ & $\begin{array}{l}\text { PMA diz: Então, ela } \\
\text { pergunta: } O \quad \text { que } \\
\text { comparar? }\end{array}$ \\
\hline 11 & PMA diz: & Um aluno & PMA diz: Se eu quisesse \\
\hline
\end{tabular}




\begin{tabular}{|c|c|c|c|}
\hline \# Evento & $\begin{array}{c}\text { Condições propostas por } \\
\text { PMA }\end{array}$ & Ações dos Alunos & $\begin{array}{c}\text { Ocorrências subsequentes } \\
\text { do professor }\end{array}$ \\
\hline & $\begin{array}{l}\text { comparar uma tabela com } \\
\text { a outra? }\end{array}$ & $\begin{array}{l}\text { Comparar é ver a } \\
\text { diferença entre as tabelas. }\end{array}$ & $\begin{array}{l}\text { comparar o peso e a } \\
\text { altura dos meninos e das } \\
\text { meninas, ficaria melhor } \\
\text { colocar as tabelas: em } \\
\text { cima, embaixo ou ao lado? }\end{array}$ \\
\hline 12 & $\begin{array}{l}\text { PMA diz: Se eu quisessem } \\
\text { comparar o peso e a } \\
\text { altura dos meninos e das } \\
\text { meninas, ficaria melhor } \\
\text { colocar as tabelas: em } \\
\text { cima, embaixo ou ao lado? }\end{array}$ & $\begin{array}{l}\text { Alguns alunos respondem: } \\
\text { Do lado. }\end{array}$ & $\begin{array}{l}\text { PMA diz: Por que do } \\
\text { lado? }\end{array}$ \\
\hline 13 & $\begin{array}{l}\text { PMA diz: Por que do } \\
\text { lado? }\end{array}$ & $\begin{array}{l}\text { Um aluno respondeu: } \\
\text { Porque dá para comparar } \\
\text { mais. }\end{array}$ & $\begin{array}{l}\text { PMA diz: E se eu fosse } \\
\text { colocar uma do lado da } \\
\text { outra, teria alguma coisa } \\
\text { que eu poderia tirar? }\end{array}$ \\
\hline 14 & $\begin{array}{l}\text { PMA diz: E se eu fosse } \\
\text { colocar uma do lado da } \\
\text { outra, teria alguma coisa } \\
\text { que eu poderia tirar? }\end{array}$ & $\begin{array}{l}\text { Alguns dizem não. Outros } \\
\text { dizem sim. } \\
\text { Uma aluna disse a idade. }\end{array}$ & $\begin{array}{l}\text { PMA diz: Daria para tirar } \\
\text { as meninas [O que PMA } \\
\text { quis dizer é se seria } \\
\text { possível retirar a coluna da } \\
\text { idade das meninas]? }\end{array}$ \\
\hline 15 & $\begin{array}{l}\text { PMA diz: Daria para tirar } \\
\text { as meninas? }\end{array}$ & Alguns alunos: Sim. & $\begin{array}{l}\text { PMA diz: Quem pegasse } \\
\text { essa tabela, sem conhecer } \\
\text { a tabela, como saberia que } \\
\text { essa tabela era das } \\
\text { meninas? }\end{array}$ \\
\hline 16 & $\begin{array}{l}\text { PMA diz: Quem pegasse } \\
\text { essa tabela, sem conhecer } \\
\text { a tabela, como saberia que } \\
\text { essa tabela era das } \\
\text { meninas? }\end{array}$ & $\begin{array}{l}\text { Uma aluna responde: } A \\
\text { idade, } P M A .\end{array}$ & $\begin{array}{l}\text { PMA diz: Uma aluna } \\
\text { falou que daria para tirar } \\
\text { a idade. Da onde tiraria a } \\
\text { idade? }\end{array}$ \\
\hline 17 & $\begin{array}{l}\text { PMA diz: Uma aluna } \\
\text { falou que daria para tirar } \\
\text { a idade. Da onde tiraria a } \\
\text { idade? }\end{array}$ & $\begin{array}{l}\text { A idade dos meninos. } \\
\text { Tiraria a idade dos } \\
\text { meninos e juntaria tudo } \\
\text { numa tabela só. }\end{array}$ & $\begin{array}{l}\text { PMA diz: Dá pra fazer } \\
\text { isso? }\end{array}$ \\
\hline 18 & $\begin{array}{l}\text { PMA diz: Dá pra fazer } \\
\text { isso? }\end{array}$ & $\begin{array}{l}\text { Alguns alunos respondem: } \\
\text { Não. }\end{array}$ & $\begin{array}{l}\text { PMA diz: Por que você } \\
\text { acha que não dá? }\end{array}$ \\
\hline 19 & $\begin{array}{l}\text { PMA diz: Por que você } \\
\text { acha que não dá? }\end{array}$ & $\begin{array}{l}\text { Alguns alunos respondem: } \\
\text { Não tira nada, então. }\end{array}$ & $\begin{array}{l}\text { PMA diz: Não dá para } \\
\text { tirar a idade. Aluna X, } \\
\text { explica por que não dá } \\
\text { para tirar a idade. } \\
\text { PMA desenha na lousa. } \\
\text { Primeiro desenha a tabela } \\
\text { das meninas: colunas peso } \\
\text { e estatura. Em seguida, } \\
\text { diz: E se eu fosse colocar } \\
\text { a outra tabela do lado, o } \\
\text { que eu colocaria? }\end{array}$ \\
\hline 20 & $\begin{array}{l}\text { PMA desenha na lousa. } \\
\text { Primeiro desenha a tabela } \\
\text { das meninas: colunas peso }\end{array}$ & $\begin{array}{l}\text { Alguns alunos respondem: } \\
\text { Menino. } \\
\text { Outro aluno diz: seria }\end{array}$ & $\begin{array}{l}\text { PMA diz: Seria melhor } \\
\text { colocar a idade no meio? } \\
\text { Mas, o que eu colocaria }\end{array}$ \\
\hline
\end{tabular}




\begin{tabular}{|c|c|c|c|}
\hline \# Evento & $\begin{array}{c}\text { Condições propostas por } \\
\text { PMA }\end{array}$ & Ações dos Alunos & $\begin{array}{l}\text { Ocorrências subsequentes } \\
\text { do professor }\end{array}$ \\
\hline & $\begin{array}{l}\text { e estatura. Em seguida, } \\
\text { diz: E se eu fosse colocar } \\
\text { a outra tabela do lado, o } \\
\text { que eu colocaria? }\end{array}$ & $\begin{array}{l}\text { melhor colocar a idade no } \\
\text { meio dos dois. }\end{array}$ & $\begin{array}{l}\text { aqui do lado? Meninos, } \\
\text { peso e estatura. Em } \\
\text { seguida, PMA escreve os } \\
\text { dados referentes à primeira } \\
\text { linha, preenchendo todas } \\
\text { as colunas da tabela das } \\
\text { meninas e da tabela dos } \\
\text { meninos. E continua } \\
\text { oralmente: o aluno X falou } \\
\text { assim: e a idade dos } \\
\text { meninos? Da pra mim } \\
\text { saber? }\end{array}$ \\
\hline 21 & $\begin{array}{l}\text { PMA diz: o aluno X falou } \\
\text { assim: e a idade dos } \\
\text { meninos? Dá pra mim } \\
\text { saber? }\end{array}$ & $\begin{array}{l}\text { Vários alunos falam ao } \\
\text { mesmo tempo, o que } \\
\text { prejudicou o áudio. }\end{array}$ & $\begin{array}{l}\text { PMA diz: Daí, vai seguir } \\
\text { mesma idade do que? }\end{array}$ \\
\hline 22 & $\begin{array}{l}\text { PMA diz: Daí, vai seguir } \\
\text { mesma idade do que? }\end{array}$ & $\begin{array}{l}\text { Alguns alunos respondem: } \\
\text { Das meninas. }\end{array}$ & $\begin{array}{l}\text { PMA diz: Das meninas. } \\
\text { Daí o Aluno X falou para } \\
\text { colocar a idade no meio } \\
\text { da tabela. O que vocês } \\
\text { acham? Ficou melhor ou } \\
\text { pior para ver a tabela? }\end{array}$ \\
\hline 23 & $\begin{array}{l}\text { PMA diz: Das meninas. } \\
\text { Daí o Aluno X falou para } \\
\text { colocar a idade no meio } \\
\text { da tabela. O que vocês } \\
\text { acham? Ficou melhor ou } \\
\text { pior para ver a tabela? }\end{array}$ & $\begin{array}{l}\text { Alguns alunos respondem: } \\
\text { Pior. Outros: Melhor. }\end{array}$ & $\begin{array}{l}\text { PMA diz: Vocês acham } \\
\text { que aqui no meio ficaria } \\
\text { pior. Quem sabe explicar? } \\
\text { Vocês falaram que aqui no } \\
\text { meio ficaria pior, mas por } \\
\text { que ficaria pior? }\end{array}$ \\
\hline 24 & $\begin{array}{l}\text { PMA diz: Vocês acham } \\
\text { que aqui no meio ficaria } \\
\text { pior. Quem sabe explicar? } \\
\text { Vocês falaram que aqui no } \\
\text { meio ficaria pior, mas por } \\
\text { que ficaria pior? }\end{array}$ & $\begin{array}{l}\text { Uma aluna fala que } \\
\text { poderia confundir com o } \\
\text { peso. }\end{array}$ & $\begin{array}{l}\text { PMA diz: Ela falou que } \\
\text { poderia confundir com o } \\
\text { peso. Não sei. O que vocês } \\
\text { acham? }\end{array}$ \\
\hline 25 & $\begin{array}{l}\text { PMA diz: Ela falou que } \\
\text { poderia confundir com o } \\
\text { peso. Não sei. O que vocês } \\
\text { acham? }\end{array}$ & $\begin{array}{l}\text { Um aluno diz: Ah PMA } \\
\text { deixa assim mesmo. } \\
\text { Uma aluna responde: Se } \\
\text { colocasse no meio ficaria } \\
\text { separada. }\end{array}$ & $\begin{array}{l}\text { PMA diz: Ficaria } \\
\text { separado? Então, vocês } \\
\text { acham que fica melhor } \\
\text { aonde? Aqui ou aqui? [e } \\
\text { aponta na lousa a primeira } \\
\text { coluna e o meio da tabela] }\end{array}$ \\
\hline 26 & $\begin{array}{l}\text { PMA diz: } \text { Ficaria } \\
\text { separado? Então, vocês } \\
\text { acham que fica melhor } \\
\text { aonde? Aqui ou aqui? }(e \\
\text { aponta na lousa a } \\
\text { primeira coluna e a } \\
\text { segunda coluna) }\end{array}$ & $\begin{array}{l}\text { Alguns alunos falam no } \\
\text { meio. }\end{array}$ & $\begin{array}{l}\text { PMA diz: Aluna } X \text {, onde } \\
\text { você acha que ficaria } \\
\text { melhor? }\end{array}$ \\
\hline 27 & $\begin{array}{l}\text { PMA diz: Aluna X, onde } \\
\text { você acha que ficaria } \\
\text { melhor? }\end{array}$ & $\begin{array}{l}\text { A aluna responde: } N a \\
\text { frente. Porque dá para ver } \\
\text { melhor. }\end{array}$ & $\begin{array}{l}\text { PMA diz: Ela falou que dá } \\
\text { pra ver melhor aqui assim } \\
\text { oh [e percorre com a mão }\end{array}$ \\
\hline
\end{tabular}




\begin{tabular}{|c|c|c|c|}
\hline \# Evento & $\begin{array}{c}\text { Condições propostas por } \\
\text { PMA }\end{array}$ & Ações dos Alunos & $\begin{array}{c}\text { Ocorrências subsequentes } \\
\text { do professor }\end{array}$ \\
\hline & & & $\begin{array}{l}\text { uma das linhas da tabela]. } \\
\text { Depois, continua: Então, } \\
\text { agora, vocês pegam e } \\
\text { recortam as duas tabelas } \\
\text { separadas. }\end{array}$ \\
\hline 28 & $\begin{array}{l}\text { PMA diz: Então, agora, } \\
\text { vocês pegam e recortam as } \\
\text { duas tabelas separadas. } \\
\text { A tabela do meu quadro é } \\
\text { a tabela todinha, pegando } \\
\text { a tabela das meninas, dos } \\
\text { meninos. PMA mostra } \\
\text { uma tabela em tamanho } \\
\text { maior que representa como } \\
\text { os alunos devem compor a } \\
\text { união das duas tabelas. }\end{array}$ & $\begin{array}{l}\text { Um aluno pergunta: } P M A \text {, } \\
\text { posso tirar a idade dele? }\end{array}$ & $\begin{array}{l}\text { PMA diz: Primeiro corta, } \\
\text { depois ... Os alunos estão } \\
\text { discutindo como cortar as } \\
\text { tabelas e o áudio com a } \\
\text { fala de PMA ficou } \\
\text { prejudicado. } \\
\text { Um aluno levanta, vai até } \\
\text { PMA e faz uma pergunta. } \\
\text { PMA então diz para a } \\
\text { turma: O aluno X está } \\
\text { perguntando se é para } \\
\text { cortar aqui no meio. É } \\
\text { para cortar aqui no meio? } \\
\text { [e mostra, utilizando a } \\
\text { folha do aluno, o meio da } \\
\text { folha]. }\end{array}$ \\
\hline 29 & $\begin{array}{l}\text { PMA diz: } O \text { aluno X está } \\
\text { perguntando se é para } \\
\text { cortar aqui no meio. É } \\
\text { para cortar aqui no meio? }\end{array}$ & Um aluno responde: é. & $\begin{array}{l}\text { PMA diz: Como que é pra } \\
\text { cortar? }\end{array}$ \\
\hline 30 & $\begin{array}{l}\text { PMA diz: Como que é pra } \\
\text { cortar? }\end{array}$ & Nenhum aluno responde. & $\begin{array}{l}\text { PMA diz: } O \text { que está em } \\
\text { volta é isso daqui e isso } \\
\text { daqui [apontando para a } \\
\text { folha de papel voltada para } \\
\text { a turma nas sobras em } \\
\text { branco em torno das } \\
\text { tabelas]. }\end{array}$ \\
\hline \multirow[t]{2}{*}{31} & $\begin{array}{l}\text { PMA estava na frente da } \\
\text { sala. }\end{array}$ & $\begin{array}{l}\text { Um aluno pergunta: cola } \\
\text { no caderno PMA? }\end{array}$ & $\begin{array}{l}\text { PMA diz: Não, espera um } \\
\text { pouco. }\end{array}$ \\
\hline & & & $\begin{array}{l}\text { PMA, pega dois exemplos } \\
\text { de tabelas recortadas de } \\
\text { maneiras diferentes e diz: } \\
\text { Tem gente perguntando se } \\
\text { é para deixar assim ou } \\
\text { assim [cada modelo estava } \\
\text { em uma das mãos]. Como } \\
\text { é pra deixar? }\end{array}$ \\
\hline 32 & $\begin{array}{l}\text { PMA, pega dois exemplos } \\
\text { de tabelas recortadas de } \\
\text { maneiras diferentes e diz: } \\
\text { Tem gente perguntando se } \\
e ́ \text { para deixar assim ou } \\
\text { assim [cada modelo estava }\end{array}$ & $\begin{array}{l}\text { Alguns alunos apontam } \\
\text { para a mão direita de } \\
\text { PMA. }\end{array}$ & $\begin{array}{l}\text { Em seguida, PMA levanta } \\
\text { a mão direita e esquerda, } \\
\text { dizendo: assim [levanta a } \\
\text { mão direita] ou assim } \\
\text { [levanta a mão esquerda]. }\end{array}$ \\
\hline
\end{tabular}




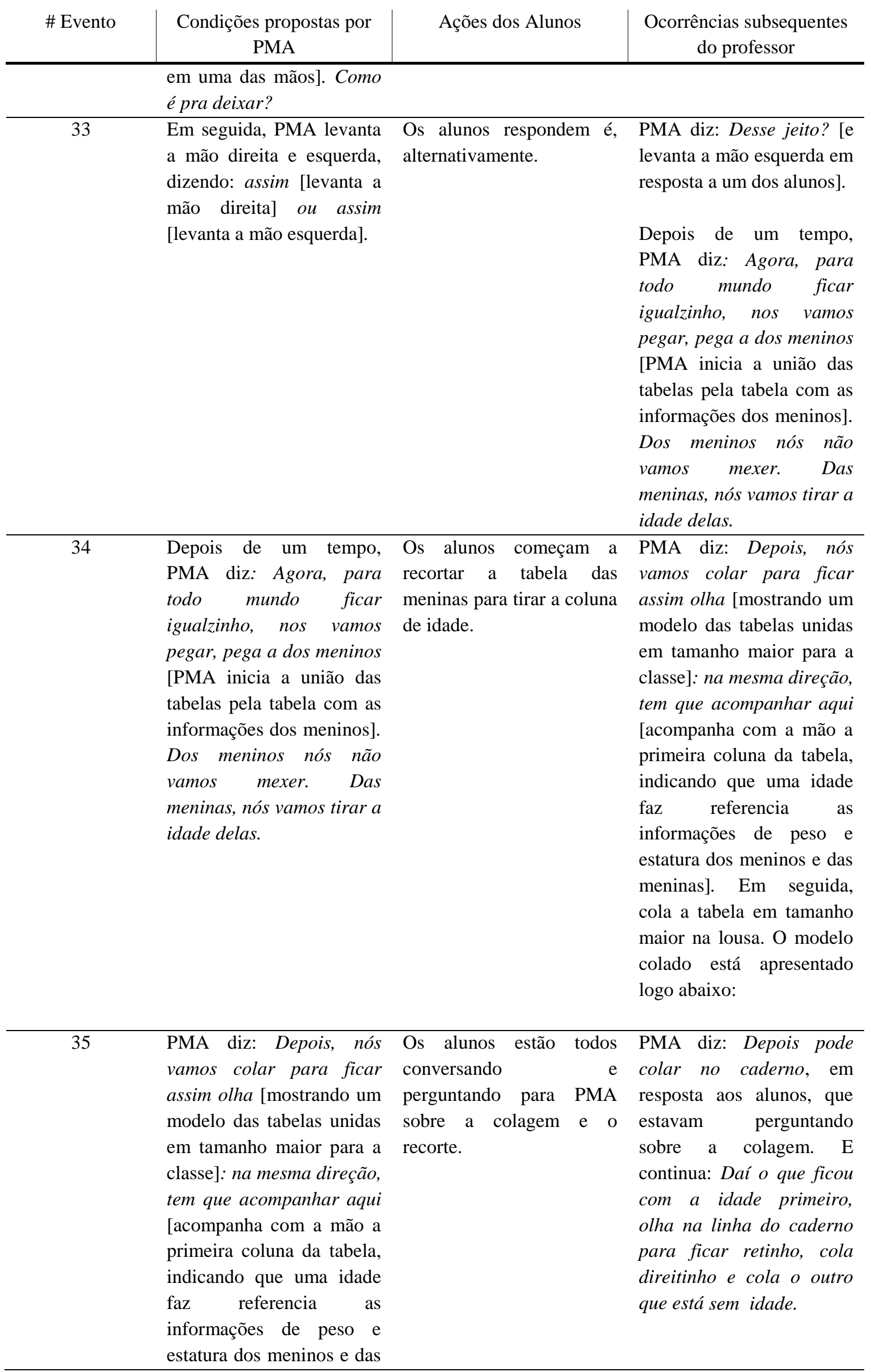




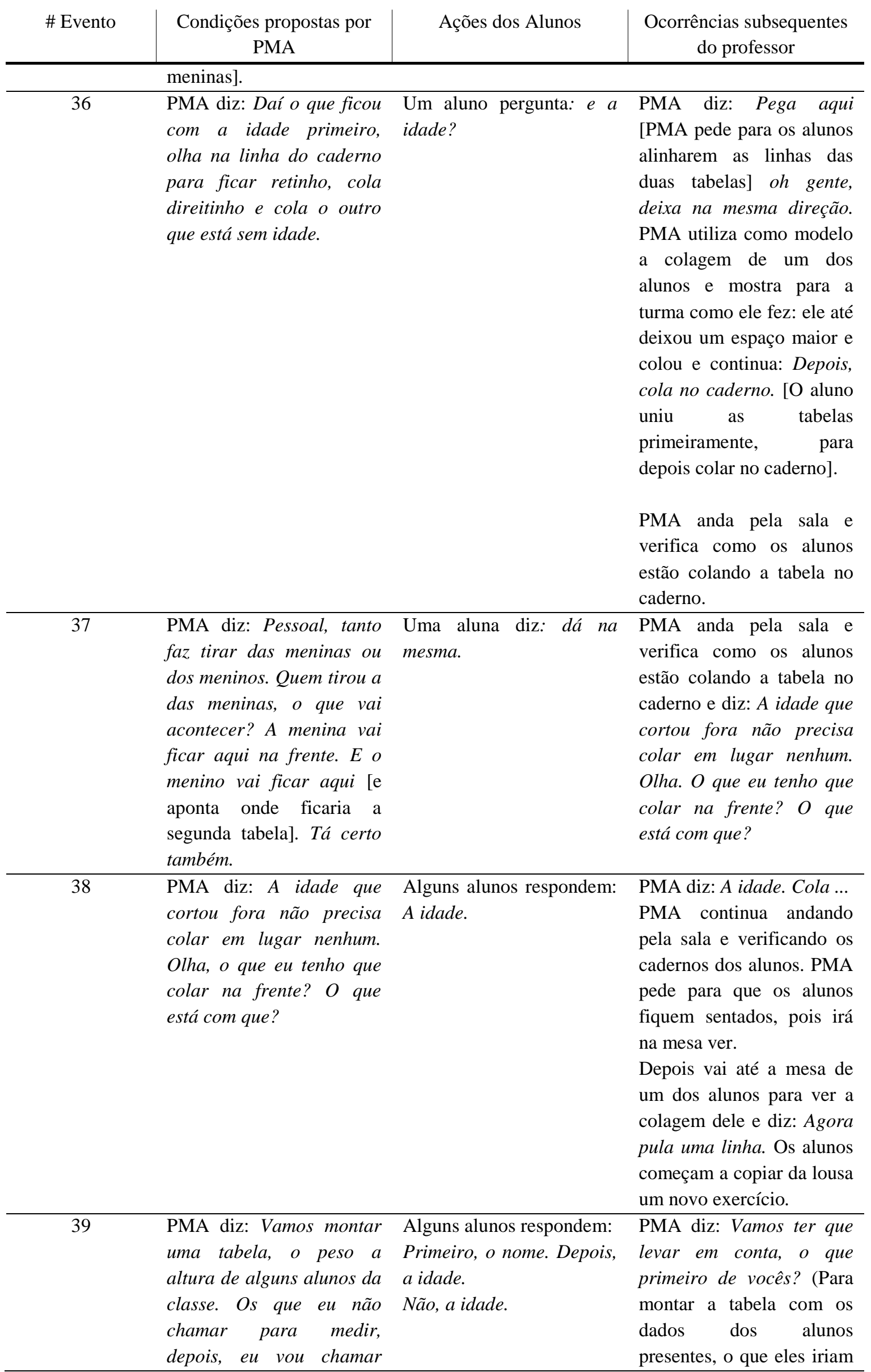




\begin{tabular}{|c|c|c|c|}
\hline \# Evento & $\begin{array}{c}\text { Condições propostas por } \\
\text { PMA }\end{array}$ & Ações dos Alunos & $\begin{array}{c}\text { Ocorrências subsequentes } \\
\text { do professor }\end{array}$ \\
\hline & $\begin{array}{l}\text { todo mundo. Só para não } \\
\text { ficar muito difícil para } \\
\text { olhar isso depois nós } \\
\text { vamos pegar só de alguns } \\
\text { meninos e de algumas } \\
\text { meninas. Só que eu quero } \\
\text { acrescentar mais um dado. } \\
\text { O que eu quero que não } \\
\text { tinha na outra tabela? o } \\
\text { nome do aluno. Onde } \\
\text { devemos colocar o nome? } \\
\text { Primeiro o nome ou a } \\
\text { idade? }\end{array}$ & & $\begin{array}{l}\text { levar em } \quad \text { conta } \\
\text { primeiramente) }\end{array}$ \\
\hline 40 & $\begin{array}{l}\text { PMA diz: Vamos ter que } \\
\text { levar em conta, o que } \\
\text { primeiro de vocês? } \\
\text { O primeiro que vou olhar } \\
\text { é a idade de vocês. O que } \\
\text { fica mais fácil colocar } \\
\text { primeiro, então? }\end{array}$ & $\begin{array}{l}\text { Alguns alunos respondem: } \\
\text { A idade. }\end{array}$ & $\begin{array}{l}\text { PMA diz: Depois da } \\
\text { idade, eu vou colocar o } \\
\text { que? }\end{array}$ \\
\hline 41 & $\begin{array}{l}\text { PMA diz: Depois da } \\
\text { idade, eu vou colocar o } \\
\text { que? }\end{array}$ & $\begin{array}{l}\text { Alguns alunos respondem: } \\
\text { Idade. }\end{array}$ & $\begin{array}{l}\text { PMA diz: Depois eu vou } \\
\text { colocar o quê? }\end{array}$ \\
\hline 42 & $\begin{array}{l}\text { PMA diz: Depois eu vou } \\
\text { colocar o que? }\end{array}$ & $\begin{array}{l}\text { Alguns alunos respondem: } \\
\text { Meninos! }\end{array}$ & $\begin{array}{l}\text { PMA diz: Meninos } \\
\text { Meninas, depois o quê? }\end{array}$ \\
\hline 43 & $\begin{array}{l}\text { PMA diz: Meninos } e \\
\text { Meninas, depois o que? }\end{array}$ & $\begin{array}{l}\text { Alguns alunos respondem: } \\
\text { O nome. }\end{array}$ & PMA diz: Depois o quê?? \\
\hline 44 & PMA diz: Depois o que? & $\begin{array}{l}\text { Alguns alunos respondem: } \\
\text { O peso. }\end{array}$ & PMA diz: E depois? \\
\hline \multirow[t]{2}{*}{45} & PMA diz: E depois? & $\begin{array}{l}\text { Alguns alunos respondem: } \\
\text { A estatura. }\end{array}$ & $\begin{array}{l}\text { PMA diz: A estatura em } \\
\text { cm. E, depois nas meninas } \\
\text { a mesma coisa. } \\
\text { Quando montar a tabela, } \\
\text { deixar espaço suficiente } \\
\text { entre as colunas tanto dos } \\
\text { meninos, quanto das } \\
\text { meninas para poder } \\
\text { escrever. }\end{array}$ \\
\hline & & & $\begin{array}{l}\text { Em seguida, PMA anda } \\
\text { pela sala de aula para } \\
\text { verificar como os alunos } \\
\text { estão elaborando a tabela. }\end{array}$ \\
\hline 46 & $\begin{array}{l}\text { PMA chama uma Aluna X } \\
\text { para começar a preencher } \\
\text { a tabela e pergunta: } \\
\text { Quantos anos aluna X? }\end{array}$ & $\begin{array}{llll}\text { Aluna } & \mathrm{X} & \text { responde: } & 10 \\
\text { anos. } & & & \\
\end{array}$ & $\begin{array}{l}\text { PMA diz: A aluna X tem } \\
10 \text { anos. Dá certo colocar } \\
\text { aqui? [e aponta para a } \\
\text { primeira linha da tabela, } \\
\text { que já está preenchida com } \\
\text { os dados de um menino de } \\
10 \text { anos] }\end{array}$ \\
\hline
\end{tabular}




\begin{tabular}{|c|c|c|c|}
\hline \# Evento & $\begin{array}{c}\text { Condições propostas por } \\
\text { PMA }\end{array}$ & Ações dos Alunos & $\begin{array}{c}\text { Ocorrências subsequentes } \\
\text { do professor }\end{array}$ \\
\hline 47 & $\begin{array}{l}\text { PMA diz: A aluna } X \text { tem } \\
10 \text { anos. Dá certo colocar } \\
\text { aqui? [e aponta para a } \\
\text { primeira linha da tabela, } \\
\text { que já está preenchida com } \\
\text { os dados de um menino de } \\
10 \text { anos] }\end{array}$ & $\begin{array}{l}\text { Um aluno responde: dá. } \\
\text { Outro aluno diz: coloca } \\
\text { embaixo PMA. }\end{array}$ & $\begin{array}{l}\text { PMA diz: Ela é menina, } \\
\text { ela tem 10 anos, posso } \\
\text { colocar ela aqui? } \\
\text { [apontando para a parte da } \\
\text { tabela com as colunas das } \\
\text { meninas] }\end{array}$ \\
\hline 48 & $\begin{array}{l}\text { PMA diz: Ela é menina, } \\
\text { ela tem 10 anos, posso } \\
\text { colocar ela aqui? } \\
\text { [apontando para a parte da } \\
\text { tabela com as colunas das } \\
\text { meninas] }\end{array}$ & Um aluno responde: pode. & $\begin{array}{l}\text { PMA escreve a idade da } \\
\text { aluna X na coluna } \\
\text { correspondente } \\
\text { primeira linha e diz: Agora } \\
\text { o peso. }\end{array}$ \\
\hline 49 & PMA diz: Agora o peso. & $\begin{array}{l}\text { A aluna } \mathrm{X} \text { responde } \mathrm{o} \\
\text { peso. }\end{array}$ & $\begin{array}{l}\text { PMA escreve o peso na } \\
\text { coluna correspondente na } \\
\text { lousa e continua: vamos } \\
\text { ver a altura e com uma fita } \\
\text { métrica. Começa a medir a } \\
\text { aluna X. Neste momento, } \\
\text { PMA chama outra aluna } \\
\text { para auxiliar a verificação. }\end{array}$ \\
\hline 50 & $\begin{array}{l}\text { Neste momento, PMA } \\
\text { chama outra aluna para } \\
\text { auxiliar a verificação. }\end{array}$ & $\begin{array}{l}\text { A aluna responde, mas } \\
\text { outros alunos estão } \\
\text { falando também e não é } \\
\text { possível escutar a resposta } \\
\text { da aluna. }\end{array}$ & $\begin{array}{l}\text { PMA diz: Ela disse que a } \\
\text { aluna X tem } 1 \text { metro e } 40 . \\
\text { Então, quanto que dá em } \\
\text { cm? }\end{array}$ \\
\hline 51 & $\begin{array}{l}\text { PMA diz: Ela disse que a } \\
\text { aluna X tem } 1 \text { metro e } 40 . \\
\text { Então, quanto que dá em } \\
\text { cm? }\end{array}$ & Os alunos não respondem. & $\begin{array}{l}\text { PMA diz: } 140 \mathrm{~cm} \text {. Escreve } \\
\text { na lousa o valor da altura } \\
\text { na coluna correspondente } \\
\text { e continua: Agora um } \\
\text { menino. Tem algum } \\
\text { menino que tem menos de } \\
10 \text { anos? Tem alguém } \\
\text { menos que } 9 \text { ? }\end{array}$ \\
\hline 52 & $\begin{array}{l}\text { PMA diz: Agora um } \\
\text { menino. Tem algum } \\
\text { menino que tem menos de } \\
10 \text { anos? Tem alguém } \\
\text { menos que 9? }\end{array}$ & $\begin{array}{l}\text { Vários alunos dizem que } \\
\text { tem } 10 \text { anos. Um aluno } \\
\text { responde que tem } 9 \text { anos. }\end{array}$ & $\begin{array}{l}\text { PMA diz: Você sabe seu } \\
\text { peso? Quantos anos você } \\
\text { tem? }\end{array}$ \\
\hline 53 & $\begin{array}{l}\text { PMA diz: Quantos anos } \\
\text { você tem? }\end{array}$ & O aluno responde: 9 & $\begin{array}{l}\text { PMA diz: Quanto você } \\
\text { pesa? }\end{array}$ \\
\hline 54 & $\begin{array}{l}\text { PMA diz: Quanto você } \\
\text { pesa? }\end{array}$ & O aluno responde. & $\begin{array}{l}\text { PMA mede o aluno e } \\
\text { solicita que outra aluna vá } \\
\text { até a frente e diga a } \\
\text { estatura do aluno. }\end{array}$ \\
\hline 55 & $\begin{array}{l}\text { PMA mede o aluno e } \\
\text { solicita que outra aluna vá } \\
\text { até a frente e diga a } \\
\text { estatura do aluno. }\end{array}$ & $\begin{array}{l}\text { A aluna responde, mas } \\
\text { outros alunos estão } \\
\text { falando também e não é } \\
\text { possível escutar a resposta } \\
\text { da aluna. }\end{array}$ & $\begin{array}{l}\text { PMA diz: } 1 \text { metro e } 37 \mathrm{~cm} \text {. } \\
\text { Quanto que dá em metros? }\end{array}$ \\
\hline
\end{tabular}




\begin{tabular}{|c|c|c|c|}
\hline \# Evento & $\begin{array}{c}\text { Condições propostas por } \\
\text { PMA }\end{array}$ & Ações dos Alunos & $\begin{array}{c}\text { Ocorrências subsequentes } \\
\text { do professor }\end{array}$ \\
\hline 56 & $\begin{array}{l}\text { PMA diz: } 1 \text { metro e } 37 \mathrm{~cm} \text {. } \\
\text { Quanto que dá em metros? }\end{array}$ & Nenhum aluno responde. & $\begin{array}{l}\text { PMA diz: } 1 \text { metro e } 37 \mathrm{~cm} \text {. } \\
\text { Quem tem } 9 \text { anos? Não } \\
\text { tem nenhuma menina que } \\
\text { tem } 9 \text { anos? [as meninas } \\
\text { que têm } 9 \text { anos não sabem } \\
\text { quanto pesa]. E continua: } \\
\text { A aluna X tem } 10 \text { anos. Eu } \\
\text { vou poder colocar ela } \\
\text { aqui? [aponta para a } \\
\text { segunda linha, que foi } \\
\text { iniciada com um menino } \\
\text { de } 9 \text { anos]. }\end{array}$ \\
\hline 57 & $\begin{array}{l}\text { PMA diz: A aluna } X \text { tem } \\
10 \text { anos. Eu vou poder } \\
\text { colocar ela aqui? [aponta } \\
\text { para a segunda linha, que } \\
\text { foi iniciada com um } \\
\text { menino de } 9 \text { anos]. }\end{array}$ & $\begin{array}{l}\text { Alguns alunos respondem: } \\
\text { Não. }\end{array}$ & $\begin{array}{l}\text { PMA diz: Por que? } \\
\text { Porque aqui é só a idade } \\
\text { de } 9 . \\
\text { PMA desenha uma nova } \\
\text { linha e escreve a idade da } \\
\text { aluna X (esta é a terceira } \\
\text { linha da tabela) }\end{array}$ \\
\hline 58 & $\begin{array}{l}\text { PMA diz: Quanto você } \\
\text { pesa? }\end{array}$ & A aluna responde. & $\begin{array}{l}\text { PMA escreve o valor do } \\
\text { peso da aluna e mede sua } \\
\text { altura com a ajuda de outra } \\
\text { aluna. }\end{array}$ \\
\hline 59 & $\begin{array}{l}\text { PMA escreve o valor do } \\
\text { peso da aluna e mede sua } \\
\text { altura com a ajuda de outra } \\
\text { aluna. }\end{array}$ & $\begin{array}{l}\text { A aluna responde, mas } \\
\text { outros alunos estão } \\
\text { falando também e não é } \\
\text { possível escutar a resposta } \\
\text { da aluna. }\end{array}$ & $\begin{array}{l}\text { PMA diz: } 1 \text { metro e } 35 \mathrm{~cm} \text {. } \\
\text { Quanto que dá em metros? } \\
135 \mathrm{~cm} \text {. Qual é o menino } \\
\text { que tem } 10 \text { anos? E ela } \\
\text { preenche as colunas } \\
\text { referentes aos dados dos } \\
\text { meninos, na mesma linha } \\
\text { da aluna anterior que tinha } \\
10 \text { anos. }\end{array}$ \\
\hline
\end{tabular}

Tabela 17 - Tabela Unidades de Análises ou Hipóteses - H29 - PMA - UD - 01

\section{Descrição e análise dos eventos registrados}

Diante dos eventos dispostos anteriormente foi possível constatar algumas características reincidentes no desempenho de PMA no contexto da disposição de condições de ensino, tanto quando em ações subsequientes aos desempenhos ou respostas dos alunos.

Em termos das condições que antecedem os desempenhos selecionados dos alunos para a $\mathrm{H} 29$, pode-se constatar que, praticamente durante todo o período compreendido pelos eventos selecionados, PMA forneceu questões e induziu oralmente a participação dos alunos sem, contudo, explicitar os objetivos que justificavam as alterações ou modificações solicitadas nos modos de apresentação dos resultados. Em outros termos, os alunos foram 
reincidentemente indagados sobre propostas de alterações nas tabelas sem que tais solicitações fossem acompanhadas das justificativas para tais modificações, em particular, em termos dos problemas ou limitações dos modos de apresentação de dados já discutidos anteriormente na aula.

Por sua vez, quanto às ações de PMA que foram subseqüentes aos desempenhos ou respostas dos alunos, três aspectos devem ser destacados:

- O primeiro aspecto diz respeito sobre as ações de PMA ao discutir as respostas fornecidas pelos alunos. Suas ações subsequentes prescindem de esclarecer sobre os objetivos das alterações ou modificações solicitadas nas tabelas. Além disso, as respostas fornecidas são comentadas de modo seletivo sem o estabelecimento de vínculos ou de análises comparativas entre as respostas fornecidas e as justificativas ou mesmo as respostas previstas.

- Como segundo aspecto, cabe mencionar que, diante de posicionamentos ou respostas antagônicas e excludentes fornecidos pelos alunos, PMA, ora explorava de modo seletivo uma das respostas, ora estimulava a participação de outros alunos (isso pode ser observado entre os eventos \#24 e \#27) e, por fim, algumas vezes, oralizava novas questões. Todas estas operações prescindiam da exploração dos fatores ou variáveis que poderiam justificar respostas antagônicas.

- Por fim, como terceiro aspecto, pode-se constatar que, diante da ausência da emissão de respostas previstas/esperada dos alunos, PMA dispôs para os alunos tais respostas.

\subsubsection{Etapa 3 - Síntese das análises obtidas na Etapa 2 da UD - 01 de PMA}

Diante da Proposta Curricular do Estado de São Paulo para o Ensino Fundamental - Ciclo I, PMA em sua proposta de atividade, desconsiderando o como foram realizadas as interações registradas durante a análise das aulas, aborda alguns dos conteúdos que oportunizam aos alunos desenvolverem habilidades e competências previstas na matriz da proposta curricular: resolver problemas com dados apresentados de maneira organizada por meio de tabelas simples, gráficos de colunas, tabelas de dupla entrada e gráficos de barras. Embora a atividade, diante do que foi registrado em vídeo, tenha como objetivo a resolução 
de problemas com dados apresentados de maneira organizada por meio de tabelas de simples. Adiante, seguem as análises das interações de PMA promovidas aos alunos.

As interações registradas nas aulas da UD-01 de PMA evidenciaram de modo reincidente, alguns aspectos da prática de ensino de PMA, tais como: a independência de suas ações em relação à obtenção de medidas sobre os desempenhos dos alunos; a utilização de estratégias orais em questionamentos muito gerais; a criação de condições favoráveis para a manifestação de repertórios de comportamentos para a cópia; medidas de desempenho relacionadas aos resultados sem a preocupação com as fontes de controle de estímulo; insistência em determinados questionamentos que ignoraram a ausência de repertórios dos alunos para responder as questões; atividades que privilegiaram as interações professor-aluno somente.

Assim, nos eventos nos quais ocorreram respostas dos alunos, independentemente se estas eram divergentes ou corretas, para questionamentos expostos por PMA, ela prosseguiu nas explicações orais sem explorar, contudo, os possíveis fatores relacionados com a determinação das respostas emitidas, muitas vezes, enfatizando uma resolução com base em um modelo definido por ela mesma. Além disso, pode-se observar no vídeo registrado, que ao colocar para a turma um questionamento, duas ocorrências foram reincidentes: ou os mesmos alunos respondiam a questão ou ela mesma o fazia isso.

Quando uma resposta correta foi emitida, PMA prescindiu de explorar tal ocorrência, introduzindo indagações que conduziram os alunos a novas habilidades, ou seja, não ressaltava correspondências entre as indagações iniciais que propiciariam a ocorrência das medidas comportamentais esperadas.

Observou-se também que as ações de PMA subsequentes às respostas dos alunos careciam de função instrucional, que permitiria ampliar as possibilidades de aprimoramento das respostas, ou seja, carecem de esclarecimentos sobre as diferenças entre o que os alunos responderam e as respostas esperadas por PMA. Além disso, em algumas interações foi constatado que atividades desenvolvidas não necessariamente estavam vinculadas aos conteúdos em estudo de forma clara, uma vez que PMA prescinde de esclarecer os objetivos da sequência instrucional elaborada para o plano de ensino.

PMA introduziu outros assuntos em sequências de interações, cujas interações anteriores elaboradas prescindiram de oportunidade para que o aluno descrevesse como e por quê emitiu determinadas respostas.

As respostas emitidas pelos alunos, durante tais interações, também seguiram um padrão de emissão que as caracterizam como respostas de confirmação ou de acréscimo às 
análises de PMA. Com isso, pela caracterização de alguns dos episódios tratados aqui, nos quais alguns são descritos como habilidades de GIII, no qual espera-se que o aluno demonstre a Competência para Compreender, PMA prescinde de elaborar um contexto que permita tal demonstração por parte do aluno. As condições criadas por PMA, que puderam ser observadas no vídeo, mostram que ela expõe a atividade, fixa um prazo para a realização da mesma e a corrige na lousa. Tais condições privilegiaram a cópia do colega ou da lousa, a emissão de respostas diretivas e objetivas, pois em muitas ocasiões a atividade era construída em conjunto e, portanto, prescindiram de oportunizar ao aluno que realizasse a análise.

A construção da tabela em conjunto expõe outra característica da prática de ensino de PMA: os alunos forneciam dados, enquanto PMA criava a tabela. Com isso, a medida de desempenho produzida nos alunos foi a cópia e a reprodução de respostas produzidas por PMA na resolução dos exercícios.

Cabe mencionar ainda, que PMA descreveu, comentou, selecionou as respostas que seriam exploradas e, muitas vezes, dispôs para os alunos tais respostas, independentemente da emissão de respostas pelos alunos que poderiam indicar a necessidade de tais ações ou mesmo de ações distintas daquelas emitidas por PMA.

Deste modo, ao prescindir de esclarecer sobre os objetivos e as funções instrucionais das atividades com as tabelas, explorando as alterações e modificações elaboradas e as respostas emitidas pelos alunos, é evidente que as interações registradas nas aulas da UD - 01 praticamente ignoram procedimentos por meio dos quais PMA poderia obter medidas dos possíveis efeitos de suas ações sobre os repertórios previstos para os respectivos conteúdos curriculares. 


\subsection{RESULTADOS DE PMA - UD - 02}

A Unidade Didática - 02 de PMA tem como tema principal a Leitura e Construção de Gráficos. Para desenvolver este tema, PMA propõe a seguinte atividade: "Serviço Metereológico: Levando em conta o serviço metereológico de Bauru no decorrer do dia 01/04 à 07/04 obtivemos os seguintes dados:"

\subsubsection{Etapa 1 - Caracterização das habilidades diante das práticas de ensino de PMA}

\begin{tabular}{|c|c|c|c|c|c|c|c|c|c|c|c|c|}
\hline \multirow{2}{*}{$\begin{array}{c}\text { Tempo de } \\
\text { Vídeo }\end{array}$} & \multicolumn{3}{|c|}{ Tema 1} & \multicolumn{3}{|c|}{ Tema 2} & \multicolumn{3}{|c|}{ Tema 3} & \multicolumn{3}{|c|}{ Tema 4} \\
\hline & GI & GII & GIII & GI & GII & GIII & GI & GII & GIII & GI & GII & GIII \\
\hline $06^{\prime} 00$ & & & & & & & & & & & & $\mathrm{H} 30$ \\
\hline 7’11 & & & & H17 & & & & & & & & \\
\hline $11 ’ 23$ & & & & & & & $\mathrm{H} 22$ & & & & & \\
\hline 13 '52 & & & & & & & & & & & & $\mathrm{H} 30$ \\
\hline $40 ’ 10$ & & & & & & & & & & & & $\mathrm{H} 29$ \\
\hline $75 ’ 24$ & & & & & & & & & & & & $\mathrm{H} 30$ \\
\hline
\end{tabular}

Tabela 18 - Tabela de Caracterização das Habilidades - UD 02 - PMA

Ao assistir a Unidade Didática 02 de PMA, a pesquisadora vinculou as práticas de ensino e de avaliação observadas nas gravações com as habilidades inseridas na tabela acima. As habilidades relacionadas estão da seguinte forma descritas no SARESP (GOVERNO DO ESTADO DE SÃO PAULO, 2009a):

- H17. Descrever a localização e a movimentação de pessoas ou objetos no espaço, em diversas representações gráficas, dando informações sobre pontos de referência e utilizando o vocabulário de posição (direita/esquerda, acima/abaixo, entre, em frente/atrás).

- H22. Reconhecer unidades de medida usuais de comprimento, de superfície, de capacidade, de tempo e de temperatura.

- H29. Ler e/ou interpretar informações e dados apresentados em tabelas e construir tabelas.

- H30. Ler e/ou interpretar informações e dados apresentados em gráficos e construir gráficos (particularmente gráficos de colunas).

Posta a tabela acima, a seguir, foram descritas e analisadas as interações registradas considerando cada uma das habilidades vinculadas, levando em consideração a sequência na qual as interações ocorreram. No transcurso da aula, as exposições orais dos 
alunos e dos professores envolvidos nos episódios de gravação considerados foram destacadas em itálico.

\subsubsection{Etapa 2 - Descrição das habilidades a partir das interações registradas e Análise das interações correspondentes às habilidades vinculadas}

Habilidade: H30. Ler e/ou interpretar informações e dados apresentados em gráficos e construir gráficos (particularmente gráficos de colunas).

\begin{tabular}{|c|c|c|c|}
\hline \# Evento & $\begin{array}{c}\text { Condições propostas por } \\
\text { PMA }\end{array}$ & Ações dos Alunos & $\begin{array}{c}\text { Ocorrências subsequentes } \\
\text { do professor }\end{array}$ \\
\hline 1 & $\begin{array}{l}\text { PMA distribui para cada } \\
\text { aluno um mapa com dados } \\
\text { metereológicos do Estado } \\
\text { de São Paulo recortado de } \\
\text { várias edições de um } \\
\text { mesmo jornal a todos os } \\
\text { alunos e inicia: Quem já } \\
\text { ouviu falar sobre o Serviço } \\
\text { metereológico? }\end{array}$ & $\begin{array}{l}\text { Um aluno respondeu: No } \\
\text { jornal e no jornal que } \\
\text { passa na } T V \text {. }\end{array}$ & $\begin{array}{l}\text { PMA: Que mapa é este, } \\
\text { que aparece no recorte do } \\
\text { jornal? }\end{array}$ \\
\hline 2 & $\begin{array}{l}\text { PMA: Que mapa é este, } \\
\text { que aparece no recorte do } \\
\text { jornal? }\end{array}$ & $\begin{array}{l}\text { Vários alunos respondem: } \\
\text { São Paulo. }\end{array}$ & $\begin{array}{l}\text { PMA: É o mapa do estado } \\
\text { de São Paulo. Aqui tem } \\
\text { algumas cidades que } \\
\text { pertencem ao estado de } \\
\text { SP. Tem duas cidades em } \\
\text { destaque no recorte. Quais } \\
\text { são elas? }\end{array}$ \\
\hline
\end{tabular}

Tabela 19 - Tabela Unidades de Análises ou Hipóteses - H30 - PMA - UD - 02

\section{Descrição e análise dos eventos registrados}

No evento \#1, PMA entregou a cada um dos alunos um recorte de jornal, com o mapa do Estado de São Paulo e os dados sobre o clima em determinadas regiões e cidades do estado em dias diferentes, como mostra a figura a seguir: 


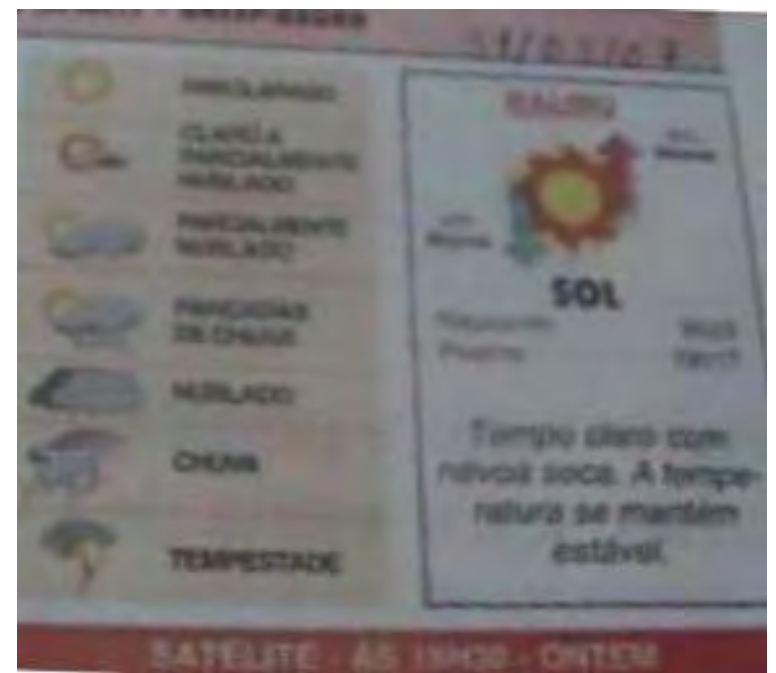

Figura 3 - Exemplo da Legenda do Mapa do Serviço Metereológico, dia 31/03/2007

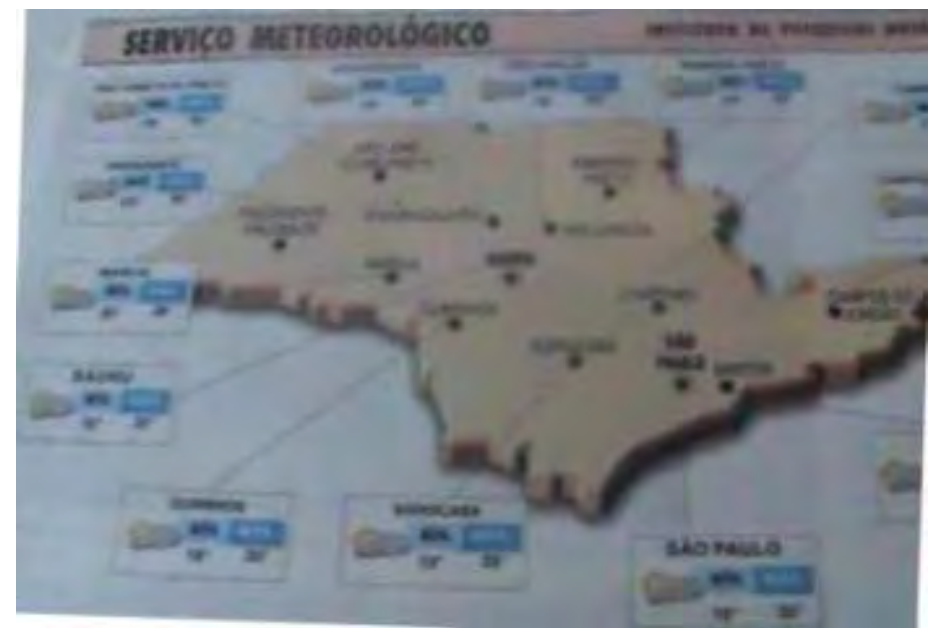

Figura 4 - Exemplo do Mapa do Serviço Metereológico, dia 31/03/2007

Ao entregar esse recorte de jornal, PMA pergunta à classe, de maneira geral, se alguém já conhecia o que significava o Serviço Metereológico. Em seguida, mediante ao mapa entregue aos alunos, apenas um aluno responde PMA, dizendo que já viu no Jornal e também no Jornal da televisão. Em seguida, PMA introduz um novo assunto, perguntando que mapa representava a figura que os alunos estavam vendo no recorte entregue. Um aluno responde que é o mapa de São Paulo. PMA concorda com a resposta do aluno e, subsequentemente, diz que existem algumas cidades que pertencem ao Estado de São Paulo, complementando que são duas cidades em destaques e quais seriam elas.

PMA, neste episódio, elabora questões indutivas, que restringem a exploração pelos alunos sobre as características da ilustração, impondo aos alunos a sua interpretação do Mapa. 
Habilidade: H17. Descrever a localização e a movimentação de pessoas ou objetos no espaço, em diversas representações gráficas, dando informações sobre pontos de referência e utilizando o vocabulário de posição (direita/esquerda, acima/abaixo, entre, em frente/atrás).

\begin{tabular}{|c|c|c|c|}
\hline \# Evento & $\begin{array}{c}\text { Condições propostas por } \\
\text { PMA }\end{array}$ & Ações dos Alunos & $\begin{array}{c}\text { Ocorrências subsequentes do } \\
\text { professor }\end{array}$ \\
\hline 1 & $\begin{array}{l}\text { PMA: É o mapa do estado } \\
\text { de São Paulo. Aqui tem } \\
\text { algumas cidades que } \\
\text { pertencem ao estado de } \\
\text { SP. Tem duas cidades em } \\
\text { destaque no recorte. Quais } \\
\text { são elas? }\end{array}$ & \begin{tabular}{lr} 
Alguns & \multicolumn{2}{c}{ alunos } \\
respondem: Bauru $e$ \\
São Paulo.
\end{tabular} & PMA: Onde está Bauru? \\
\hline 2 & PMA: Onde está Bauru? & $\begin{array}{l}\text { Um aluno responde: } N o \\
\text { Centro. }\end{array}$ & PMA: Todo mundo achou? \\
\hline 3 & $\begin{array}{l}\text { PMA: Todo mundo } \\
\text { achou? }\end{array}$ & $\begin{array}{l}\text { Um aluno responde: } E u \\
\text { não achei. } \\
\text { Uma aluna responde ao } \\
\text { aluno: No centro! } \\
\text { (PMA: deixa ele } \\
\text { achar!) }\end{array}$ & $\begin{array}{l}\text { PMA: O dia que eu recortei o } \\
\text { mapa do jornal, cada um tem } \\
\text { uma data diferente. Esse } \\
\text { mapa tem uma legenda. Que } \\
\text { legenda é essa? }\end{array}$ \\
\hline
\end{tabular}

Tabela 20 - Tabela Unidades de Análises ou Hipóteses - H17 - PMA - UD - 02

\section{Descrição e análise dos eventos registrados}

Em sequência ao questionamento iniciado anteriormente descrito, PMA pergunta quais são as duas cidades em destaque no recorte de cada um dos alunos. Alguns deles respondem Bauru e São Paulo. Subsequentemente, PMA pergunta aos alunos onde está localizada a cidade de Bauru.

Um aluno responde que Bauru está no centro do mapa. Sem comentar a resposta do aluno, PMA faz uma referência a toda turma, perguntando se todos haviam encontrado o local onde Bauru está situada no mapa. Um aluno diz que não encontrou e uma aluna responde a ele: está no centro! Neste momento, PMA interrompe a aluna e pede para que ela deixe o outro aluno encontrar o local sozinho. Ao interromper a aluna, PMA inicia um novo tema sobre o mapa.

PMA utiliza nos eventos registrados aqui questões diretivas e objetivas, o que produz respostas pontuais e específicas dos alunos. Em consequência às respostas emitidas pelos alunos, PMA não elabora posicionamentos que subsidiem as respostas já emitidas no desenvolvimento de novas respostas que contextualize os conteúdos em uma sequência instrucional. Além disso, prescinde de descrição e de investigação de relações de controle, 
que são as causas que ocasionaram a emissão da resposta, possivelmente relacionadas com a resposta emitida.

Habilidade: H30. Ler e/ou interpretar informações e dados apresentados em gráficos e construir gráficos (particularmente gráficos de colunas).

\begin{tabular}{|c|c|c|c|}
\hline \# Evento & $\begin{array}{c}\text { Condições propostas por } \\
\text { PMA }\end{array}$ & Ações dos Alunos & $\begin{array}{l}\text { Ocorrências subsequentes do } \\
\text { professor }\end{array}$ \\
\hline 1 & $\begin{array}{l}\text { PMA: O dia que eu } \\
\text { recortei o mapa do jornal, } \\
\text { cada um tem uma data } \\
\text { diferente. Esse mapa tem } \\
\text { uma legenda. Que legenda } \\
\text { é essa? }\end{array}$ & $\begin{array}{l}\text { Um aluno respondeu em } \\
\text { voz baixa. Não foi } \\
\text { possível escutá-lo. }\end{array}$ & $\begin{array}{l}\text { PMA solicita ao aluno que } \\
\text { responda alto. Mas, por } \\
\text { fim pergunta: Você acha } \\
\text { que é temperatura aqui? }\end{array}$ \\
\hline 2 & $\begin{array}{l}\text { PMA solicita que ele } \\
\text { responda alto. Mas, por } \\
\text { fim pergunta: Você acha } \\
\text { que é temperatura aqui? }\end{array}$ & $\begin{array}{l}\text { Outro aluno da } \text { sala } \\
\text { responde em voz alta: } \\
\text { Depende do dia que } \\
\text { mostra, se vai estar sol. }\end{array}$ & $\begin{array}{l}\text { PMA: É como estará o } \\
\text { tempo. Se tem um solzinho, } \\
\text { o que significa? PMA lê a } \\
\text { legenda junto aos alunos. } \\
\text { PMA descreve } \\
\text { graficamente cada símbolo } \\
\text { contido na legenda (Figura } \\
\text { 3) para os alunos e } \\
\text { pergunta aos alunos o que } \\
\text { significa cada um deles, } \\
\text { esperando que os alunos } \\
\text { lessem a descrição ao lado } \\
\text { de cada símbolo. Como } \\
\text { resposta, os alunos leram a } \\
\text { legenda apresentada na } \\
\text { tabela. Depois de ler todos } \\
\text { os símbolos com os } \\
\text { alunos, PMA fala sobre } \\
\text { um risquinho e pergunta: } \\
\text { o que tem no pedacinho } \\
\text { em que está escrito Bauru } \\
\text { e um risquinho? (Figura 4) }\end{array}$ \\
\hline
\end{tabular}

\section{Descrição e análise dos eventos registrados}

Após reconhecer a localização da Cidade de Bauru no mapa entregue aos alunos, PMA inicia a leitura dos dados contidos no recorte. Para isso, PMA diz que cada aluno da turma recebeu um mapa com uma data diferente. Em seguida, observa que o mapa contém uma legenda e pergunta aos alunos que legenda era aquela apresentada no recorte de cada um 
deles. Um aluno responde a questão e PMA solicita que ele responda em voz alta. Mas, o interrompe e finaliza o evento com a seguinte questão: você acha que é temperatura aqui?

$\mathrm{Na}$ sequência dos registros, outro aluno responde em voz alta dizendo que "Depende do dia que mostra, se vai estar sol". Essa resposta, na observação realizada pela pesquisadora, não responde a pergunta que iniciou tal ação do aluno. Porém, PMA parte desta resposta para iniciar um novo contexto de interpretação da legenda apresentada no mapa. PMA faz uma leitura da legenda, apresentando os símbolos e o que cada um deles diz a respeito da temperatura, se estará sol, se o dia será nublado, entre outros símbolos descritos por PMA.

Sendo assim, o que foi observado nestes eventos é que as respostas emitidas pelos alunos são pontuais e expressam informações em dimensão complementar sobre o conteúdo estudado. A pergunta de PMA que evoca tais respostas é antecedida por descrição e elaboração verbais de PMA que envolvem competências importantes. Ao efetuar tais elaborações, PMA elimina as possibilidades de os alunos emitirem respostas ou comportamentos consistentes com as habilidades envolvidas, restringindo a amplitude daqueles repertórios explorados com as práticas disponibilizadas.

Habilidade: H22. Reconhecer unidades de medida usuais de comprimento, de superfície, de capacidade, de tempo e de temperatura.

\begin{tabular}{c|l|l|l|l} 
\# Evento & \multicolumn{2}{|c|}{$\begin{array}{c}\text { Condições propostas por } \\
\text { PMA }\end{array}$} & Ações dos Alunos & $\begin{array}{c}\text { Ocorrências subsequentes do } \\
\text { professor }\end{array}$ \\
\hline \multirow{2}{*}{1} & PMA: É como estará o & Alguns & alunos & PMA: Só tem a temperatura \\
& tempo. O que tem no respondem: É a mínima e máxima? \\
& pedacinho em que está temperatura da mínima e & \\
& escrito Bauru e um máxima. & & \\
& risquinho?
\end{tabular}

Tabela 22 - Tabela Unidades de Análises ou Hipóteses - H22 - PMA - UD - 02

\section{Descrição e análise dos eventos registrados}

Após descrever os símbolos contidos na legenda do mapa, PMA questiona a turma sobre o que está escrito em um quadro localizado ao lado do nome da cidade de Bauru (neste mapa, há um indicativo em quadro da temperatura máxima e mínima do dia). Este quadro será nomeado pela pesquisadora como quadro de previsão metereológica para referências posteriores. Alguns alunos respondem que é "a temperatura mínima e máxima". 
Sem explorar ou apresentar feedback sobre a resposta dos alunos, PMA questiona a turma se no quadro apresentado ao lado do nome da cidade de Bauru existem apenas as informações de temperatura mínima e máxima.

Neste evento, PMA não tem uma ação subsequente que permita explorar de forma mais ampla e geral as dimensões possíveis da situação estimadora apresentada. Isso fica evidente pela resposta dos alunos, que se configura em reconhecimentos objetivos e direcionados por PMA da leitura de informações já impressas no mapa.

Habilidade: H30. Ler e/ou interpretar informações e dados apresentados em gráficos e construir gráficos (particularmente gráficos de colunas).

\begin{tabular}{|c|c|c|c|}
\hline \# Evento & $\begin{array}{c}\text { Condições propostas por } \\
\text { PMA }\end{array}$ & Ações dos Alunos & $\begin{array}{c}\text { Ocorrências subsequentes do } \\
\text { professor }\end{array}$ \\
\hline 1 & $\begin{array}{lcc}\text { PMA: Só } & \text { tem } & a \\
\text { temperatura } & \text { mínima } & e \\
\text { máxima? } & & \\
\text { mand }\end{array}$ & $\begin{array}{l}\text { Um aluno responde: Não. } \\
\text { Tem uma legenda } \\
\text { também. }\end{array}$ & PMA: $O$ que mais tem? \\
\hline 2 & PMA: $O$ que mais tem? & $\begin{array}{l}\text { Um aluno responde, mas } \\
\text { em voz baixa, que } \\
\text { somente PMA registra } \\
\text { sua resposta. }\end{array}$ & $\begin{array}{l}\text { PMA: Não, eu falei somente } \\
\text { no risquinho de Bauru, o que } \\
\text { que tem aí dentro? Está } \\
\text { escrito Bauru e o que que tem } \\
\text { aí dentro? }\end{array}$ \\
\hline 3 & $\begin{array}{l}\text { PMA: Não, eu falei } \\
\text { somente no risquinho de } \\
\text { Bauru, o que que tem aí } \\
\text { dentro? Está escrito Bauru } \\
\text { e o que que tem aí dentro? }\end{array}$ & $\begin{array}{l}\text { Um aluno responde: } A \\
\text { legenda. } \text { Tem uma } \\
\text { nuvenzinha. }\end{array}$ & $\begin{array}{l}\text { PMA: Tem como vai estar o } \\
\text { tempo, ensolarado, nublado } \\
\text { ou chuvoso e tem a } \\
\text { temperatura mínima e } \\
\text { máxima. } \\
\text { O que a mínima e máxima? }\end{array}$ \\
\hline
\end{tabular}

Tabela 23 - Tabela Unidades de Análises ou Hipóteses - H30 - PMA - UD - 02

\section{Descrição e análise dos eventos registrados}

Quando alguns alunos respondem que no quadro correspondente à cidade de Bauru no mapa apresenta as temperaturas máximas e mínimas, PMA pergunta para a turma quais outras informações estão contidas neste mesmo quadro. O objetivo é que os alunos façam o relacionamento do símbolo apresentado no quadro e a sua descrição na legenda. PMA pergunta se só tem temperatura máxima e mínima. Um dos alunos responde dizendo que não, pois verificou que há mais informações neste quadro. Outro aluno diz que no quadro é apresentada uma legenda, o que nos permite observar a falta de compreensão sobre o que o símbolo e a legenda representavam, pois ele apenas cita "legenda". PMA prescinde de discutir 
com os alunos que responderam à sua primeira questão e, na sequência, continua indagando a turma sobre o que mais eles vêem no quadro. Outro aluno responde a questão, mas PMA se posiciona contrária à resposta emitida (provavelmente, em decorrência da resposta de PMA ao aluno, pode-se concluir que ele direcionou sua leitura para outro local do mapa) e refaz a pergunta, solicitando aos alunos que observem somente o "risquinho de Bauru" (existe um seguimento de reta, riscado em preto, que une, numa extremidade, o local de Bauru no mapa e, na outra extremidade, o quadro que faz referencias às previsões metereológicas do dia).

Alguns alunos insistem na mesma resposta: legenda. Porém, um deles chega a resposta que PMA previa: "Tem uma nuvenzinha". Em seguida, PMA faz o relacionamento entre o símbolo citado pelo aluno e a legenda apresentada: “Tem como vai estar o tempo [...], tem a temperatura mínima e máxima”. Ao finalizar a interpretação/relacionamento entre os símbolos dos quadros de previsão metereológica e a legenda, PMA questiona a turma sobre o que representam as temperaturas mínima e máxima.

Nos eventos retratados acima, verificou-se que as respostas orais sustentam restritas interpretações, ou seja, a leitura do material fornecido não se mostra eficiente para produzir as respostas de interpretação de informações gráficas expressas nas ilustrações utilizadas. Diante das respostas emitidas, PMA expõe oralmente as respostas previstas, prescindindo de produzir um contexto no qual o aluno tenha possibilidades de expor seu entendimento sobre o conteúdo e, assim, permitir uma re-elaboração da prática de ensino a fim de ampliar os repertórios de análise das informações pelos alunos.

Habilidade: H22. Reconhecer unidades de medida usuais de comprimento, de superfície, de capacidade, de tempo e de temperatura.

\begin{tabular}{|c|c|c|c|}
\hline \# Evento & $\begin{array}{c}\text { Condições propostas por } \\
\text { PMA }\end{array}$ & Ações dos Alunos & $\begin{array}{l}\text { Ocorrências subsequentes do } \\
\text { professor }\end{array}$ \\
\hline 1 & $\begin{array}{l}\text { PMA: Tem como vai estar } \\
o \text { tempo, ensolarado, } \\
\text { nublado ou chuvoso e tem } \\
\text { a temperatura mínima } e \\
\text { máxima. } \\
\text { o que a mínima e } \\
\text { máxima? }\end{array}$ & $\begin{array}{l}\text { Uma aluna responde em } \\
\text { voz baixa o que ela } \\
\text { entende por temperatura } \\
\text { máxima. }\end{array}$ & $\begin{array}{l}\text { PMA pergunta para ela: você } \\
\text { acha que a mínima é? }\end{array}$ \\
\hline 2 & $\begin{array}{l}\text { PMA pergunta para ela: } \\
\text { você acha que a mínima } \\
e ́ ?\end{array}$ & $\begin{array}{l}\text { A aluna responde: } A \\
\text { mínima? É menos. }\end{array}$ & PMA: Menos, o que? \\
\hline 3 & PMA: Menos, o que? & $\begin{array}{l}\text { A aluna responde: Menos } \\
\text { chuva, menos frio, quer } \\
\text { dizer mais chuva. }\end{array}$ & PMA: E o que é o máximo? \\
\hline
\end{tabular}




\begin{tabular}{|c|c|c|c|}
\hline \# Evento & $\begin{array}{c}\text { Condições propostas por } \\
\text { PMA }\end{array}$ & Ações dos Alunos & $\begin{array}{c}\text { Ocorrências subsequentes do } \\
\text { professor }\end{array}$ \\
\hline 4 & $\begin{array}{l}\text { PMA: } E \text { o que } \quad e^{\prime} \quad \text { } \\
\text { máximo? }\end{array}$ & $\begin{array}{l}\text { Outro aluno responde: } \\
\text { Sol. Mais calor, mais } \\
\text { frio. }\end{array}$ & $\begin{array}{l}\text { PMA: O aluno falou: a } \\
\text { mínima é assim: quanto mais } \\
\text { baixa a temperatura, fica mais } \\
\text { calor ou mais frio? }\end{array}$ \\
\hline 5 & $\begin{array}{l}\text { PMA: } O \text { aluno falou: a } \\
\text { mínima é assim: quanto } \\
\text { mais baixa a temperatura, } \\
\text { fica mais calor ou mais } \\
\text { frio? }\end{array}$ & $\begin{array}{l}\text { Um aluno responde: } \\
\text { Mais frio. }\end{array}$ & $\begin{array}{l}\text { PMA: } E \text { conforme a } \\
\text { temperatura vai ficando mais } \\
\text { alta, o número maior, a } \\
\text { máxima. Vai ficando mais o } \\
\text { que? }\end{array}$ \\
\hline 6 & $\begin{array}{l}\text { PMA: E conforme a } \\
\text { temperatura vai ficando } \\
\text { mais alta, o número maior, } \\
\text { a máxima. Vai ficando } \\
\text { mais o que? }\end{array}$ & $\begin{array}{l}\text { Um aluno responde: } \\
\text { Calor. }\end{array}$ & $\begin{array}{l}\text { PMA: Mais calor. O que será } \\
\text { que é isso daqui que fica ao } \\
\text { lado do número? O que é isso } \\
\text { daqui? }\end{array}$ \\
\hline 7 & $\begin{array}{l}\text { PMA: Mais calor. O que } \\
\text { será que é isso daqui que } \\
\text { fica ao lado do número? O } \\
\text { que é isso daqui? }\end{array}$ & $\begin{array}{l}\text { Um aluno responde: } \\
\text { Símbolo do grau }\end{array}$ & PMA: Que simboliza o que? \\
\hline 8 & $\begin{array}{l}\text { PMA: Que simboliza o } \\
\text { que? }\end{array}$ & $\begin{array}{l}\text { Um aluno responde: } O \\
\text { grau. }\end{array}$ & $\begin{array}{l}\text { PMA: Então, aqui a mínima e } \\
\text { máxima, em Bauru, no meu } \\
\text { Mapa, que foi do dia } 13 / 03, \text { a } \\
\text { mínima foi } 21^{\circ} \text { C e a máxima } \\
\text { deu } 32^{\circ} \text { C. Cada dia pode } \\
\text { mudar, a mínima e a máxima. } \\
\text { Ela tem variações. Então, } \\
\text { aqui está falando assim: } \\
\text { levando em conta o serviço } \\
\text { metereológico de Bauru, no } \\
\text { decorrer do dia: } 01 / 04 \text { a } \\
\text { 07/04, podemos ver os } \\
\text { seguintes dados. }\end{array}$ \\
\hline
\end{tabular}

Tabela 24 - Tabela Unidades de Análises ou Hipóteses - H22 - PMA - UD - 02

\section{Descrição e análise dos eventos registrados}

Ao introduzir a pergunta sobre o que são ou que representam as temperaturas mínimas e máximas em uma previsão metereológica, PMA tem como objetivo, observado pela pesquisadora a partir das ocorrências no vídeo das aulas ministradas, identificar a unidade de medida utilizada nos quadros de previsão metereológica. Sendo assim, uma aluna responde em voz baixa para PMA o que entende por temperatura máxima, essa resposta foi também observada mediante a ação subsequente de PMA, que complementa a resposta da aluna com a questão sobre o que ela achava que significava a temperatura mínima. A aluna, então, responde que é menos. 
Diante da resposta "menos", PMA questiona o que significa menos. A aluna continua: "menos chuva, menos frio, quer dizer mais chuva". PMA, embora diante de uma resposta insuficiente, retoma a pergunta sobre o que significa a temperatura máxima. Neste ponto, cabe a observação acerca do que PMA tenta realizar: há uma inversão sobre o entendimento da aluna sobre o que significa "menos", nos termos de temperatura mínima. A descrição dada pela aluna corresponde melhor à temperatura máxima que à mínima. Porém, PMA não contextualiza sua questão subsequente, o que fornece um ponto de distanciamento instrucional entre os conceitos que PMA objetiva nestes eventos. Um aluno então responde: Sol. Mais calor, mais frio. PMA aliou a resposta emitida pelo aluno a outra questão, na tentativa de esclarecer as respostas antagônicas (observação da pesquisadora): quanto mais baixa a temperatura, fica mais calor ou mais frio? Um aluno responde que fica mais frio. PMA retoma a questão da temperatura máxima e os alunos respondem que quanto mais alta a temperatura, "vai ficando mais calor".

PMA aceita essa resposta como correta e questiona a turma sobre o símbolo localizado ao lado do número da temperatura. Um aluno responde que é o "Símbolo do Grau". PMA, em sua ação subseqüente, prescinde de explorar o que significa o "símbolo do grau" no desenvolvimento das respostas emitidas pelos alunos. Sendo assim, PMA interpreta o quadro de previsão metereológica de Bauru, tomando como base o mapa que estava em suas mãos e inicia uma nova atividade.

As descrições para os eventos aqui registrados demonstram que as respostas orais dos alunos são incompletas, muitas vezes antagônicas e, em alguns casos, seguidas por repetição de PMA. O que se constata, diante de tais respostas dos alunos, é que PMA prescinde de ressaltar as respostas emitidas, explorando as possíveis relações de controle, cujas quais levaram os alunos a emitirem tais respostas, sejam elas incompletas ou antagônicas.

Habilidade: H30. Ler e/ou interpretar informações e dados apresentados em gráficos e construir gráficos (particularmente gráficos de colunas).

\begin{tabular}{|c|c|c|c|}
\hline \# Evento & $\begin{array}{c}\text { Condições propostas por } \\
\text { PMA }\end{array}$ & Ações dos Alunos & $\begin{array}{l}\text { Ocorrências subsequentes do } \\
\text { professor }\end{array}$ \\
\hline 1 & $\begin{array}{l}\text { PMA: Então, aqui está } \\
\text { falando assim: levando em } \\
\text { conta o } \quad \text { serviço } \\
\text { metereológico de Bauru, } \\
\text { no decorrer do dia: } 01 / 04\end{array}$ & $\begin{array}{l}\text { Um aluno falou que } \\
\text { estava com o dia } 31 / 03 \text {. } \\
\text { O aluno que tinha o } \\
\text { Mapa com a data } 01 / 04 \text {, }\end{array}$ & $\begin{array}{l}\text { PMA: Eu já sei que vou levar } \\
\text { em conta qual cidade? }\end{array}$ \\
\hline
\end{tabular}




\begin{tabular}{|c|c|c|c|}
\hline \# Evento & $\begin{array}{c}\text { Condições propostas por } \\
\text { PMA }\end{array}$ & Ações dos Alunos & $\begin{array}{l}\text { Ocorrências subsequentes do } \\
\text { professor }\end{array}$ \\
\hline & $\begin{array}{l}\text { a 07/04, podemos ver os } \\
\text { seguintes dados. Quem } \\
\text { está com o mapinha do dia } \\
\text { 01/04? }\end{array}$ & falou com PMA. & \\
\hline 2 & $\begin{array}{l}\text { PMA: Eu já sei que vou } \\
\text { levar em conta qual } \\
\text { cidade? }\end{array}$ & $\begin{array}{l}\text { O aluno responde: } \\
\text { Bauru. }\end{array}$ & $\begin{array}{l}\text { PMA: Então, eu não preciso } \\
\text { colocar Bauru. O que está aí } \\
\text { Aluno X? Tira Bauru e como é } \\
\text { que está o tempo? Olha na } \\
\text { legenda (Figura 3) e me fala. }\end{array}$ \\
\hline 3 & $\begin{array}{l}\text { PMA: Então, eu não } \\
\text { preciso colocar Bauru. O } \\
\text { que está aí Aluno X? Tira } \\
\text { Bauru e como é que está o } \\
\text { tempo? Olha na legenda } \\
\text { (Figura 3) e me fala. }\end{array}$ & $\begin{array}{l}\text { O aluno responde: Qual } \\
\text { que é a temperatura que } \\
\text { vai estar no dia } \\
\text { primeiro? }\end{array}$ & $\begin{array}{l}\text { PMA: Então, é isso que eu } \\
\text { quero ver se você consegue. } \\
\text { Olha na legenda e me fala. } \\
\text { Achou Bauru? }\end{array}$ \\
\hline 4 & $\begin{array}{l}\text { Então, é isso que eu quero } \\
\text { ver se você consegue. } \\
\text { Olha na legenda e me fala. } \\
\text { Achou Bauru? }\end{array}$ & O aluno responde: Sim. & $\begin{array}{l}\text { PMA: E agora, como está? O } \\
\text { tempo, como está? }\end{array}$ \\
\hline 5 & $\begin{array}{l}\text { PMA: E agora, como } \\
\text { está? O tempo, como está? }\end{array}$ & $\begin{array}{l}\text { O aluno responde: Não } \\
\text { entendi. }\end{array}$ & $\begin{array}{l}\text { PMA: Não o tempo não. } \\
\text { Como está o tempo? Está } \\
\text { nublado, } \\
\text { ensolarado? }\end{array}$ \\
\hline 6 & $\begin{array}{l}\text { PMA: Não o tempo não. } \\
\text { Como está o tempo? Está } \\
\text { nublado, } \\
\text { ensolarado? }\end{array}$ & $\begin{array}{l}\mathrm{O} \text { aluno responde: } \\
\text { Parcialmente } \\
\text { nublado. }\end{array}$ & $\begin{array}{l}\text { PMA: Como é parcialmente } \\
\text { nublado? }\end{array}$ \\
\hline 7 & $\begin{array}{l}\text { PMA: } \quad \text { Como } \\
\text { parcialmente } \\
\text { nublado? }\end{array}$ & $\begin{array}{l}\text { O aluno responde: } U m a \\
\text { nuvem branca com } \\
\text { solzinho. }\end{array}$ & $\begin{array}{l}\text { PMA: Uma nuvemzinha e o } \\
\text { sol. } \\
\text { PMA desenha o símbolo na } \\
\text { lousa e continua, dizendo: } O \\
\text { que mais tem aí Aluno X? }\end{array}$ \\
\hline 8 & $\begin{array}{l}\text { PMA: Uma nuvemzinha e } \\
\text { o sol. } \\
\text { PMA desenha o símbolo } \\
\text { na lousa e continua, } \\
\text { dizendo: } O \text { que mais tem } \\
\text { aí Aluno } X \text { ? }\end{array}$ & O aluno não responde. & $\begin{array}{l}\text { PMA: Só tem o tempo? O que } \\
\text { mais que tem? Tem duas } \\
\text { temperaturas. Qual que tem? } \\
\text { A primeira é mínima ou } \\
\text { máxima? }\end{array}$ \\
\hline 9 & $\begin{array}{l}\text { Só tem o tempo? O que } \\
\text { mais que tem? Tem duas } \\
\text { temperaturas. Qual que } \\
\text { tem? A primeira é mínima } \\
\text { ou máxima? }\end{array}$ & $\begin{array}{l}\text { O aluno responde: } \\
\text { Mínima. }\end{array}$ & PMA: Quanto é a mínima? \\
\hline 10 & PMA: Quanto é a mínima? & O aluno responde: 24 . & $\begin{array}{l}\text { PMA: A mínima é 24? Onde } \\
\text { você olha? A mínima é essa } \\
\text { ou essa? }\end{array}$ \\
\hline \multirow[t]{2}{*}{11} & $\begin{array}{l}\text { PMA: A mínima é } 24 ? \\
\text { Onde você olha? A mínima } \\
\text { é essa ou essa? }\end{array}$ & O aluno responde: 19 & $\begin{array}{l}\text { PMA: Presta atenção! Você } \\
\text { tem que olhar Bauru! }\end{array}$ \\
\hline & & & PMA escreve no quadro da \\
\hline
\end{tabular}




\begin{tabular}{|c|c|c|c|}
\hline \# Evento & $\begin{array}{c}\text { Condições propostas por } \\
\text { PMA }\end{array}$ & Ações dos Alunos & $\begin{array}{l}\text { Ocorrências subsequentes do } \\
\text { professor }\end{array}$ \\
\hline & & & $\begin{array}{l}\text { lousa } 19 \text { e continua: } E \quad o \\
\text { máximo? }\end{array}$ \\
\hline \multirow[t]{2}{*}{12} & $\begin{array}{l}\text { PMA: Presta atenção! } \\
\text { Você tem que olhar Bauru! }\end{array}$ & \multirow[t]{2}{*}{ O aluno responde: 32 . } & PMA diz: 32 graus. \\
\hline & $\begin{array}{l}\text { PMA escreve no quadro da } \\
\text { lousa } 19 \text { e continua: } E \text { o } \\
\text { máximo? }\end{array}$ & & $\begin{array}{l}\text { Em seguida, escreve no } \\
\text { quadro na lousa: } 32 \text { e } \\
\text { continua: Aqui eu esqueci de } \\
\text { colocar uma coisa. O que eu } \\
\text { esqueci de colocar? }\end{array}$ \\
\hline 13 & $\begin{array}{l}\text { PMA diz: Aqui eи esqueci } \\
\text { de colocar uma coisa. O } \\
\text { que eu esqueci de colocar? }\end{array}$ & $\begin{array}{l}\text { O aluno } \\
\text { Bauru. }\end{array}$ & $\begin{array}{l}\text { PMA diz: Não. Eu falei que } \\
\text { tudo era Bauru. O que } \\
\text { esqueci? Eu deixei de } \\
\text { propósito ne ninguém } \\
\text { percebeu. O que foi? }\end{array}$ \\
\hline 14 & $\begin{array}{l}\text { PMA diz: Não. Eu falei } \\
\text { que tudo era Bauru. O que } \\
\text { esqueci? Eu deixei de } \\
\text { propósito e ninguém } \\
\text { percebeu. O que foi? }\end{array}$ & $\begin{array}{l}\text { Vários alunos } \\
\text { respondem: } \\
\text { Nuvem com chuvinha. } \\
\text { Bauru. } \\
\text { Não sei. }\end{array}$ & $\begin{array}{l}\text { percebeu. O que foi? } \\
\text { PMA, então diz: } O \text { dia, gente! } \\
\text { Dia 01/04. Depois do dia } \\
\text { primeiro, que dia vem? }\end{array}$ \\
\hline 15 & $\begin{array}{l}\text { PMA, então diz: O dia, } \\
\text { gente! Dia 01/04. Depois } \\
\text { do dia primeiro, que dia } \\
\text { vem? }\end{array}$ & $\begin{array}{l}\text { Vários alunos respondem: } \\
\text { Dia } 2 .\end{array}$ & $\begin{array}{l}\text { PMA diz: Dia 2. Quem está } \\
\text { com o mapa do dia 2? }\end{array}$ \\
\hline 16 & $\begin{array}{l}\text { PMA diz: Dia 2. Quem está } \\
\text { com o mapa do dia } 2 ?\end{array}$ & $\begin{array}{l}\text { O aluno com o recorte } \\
\text { correspondente ao dia } 2 \\
\text { respondeu. }\end{array}$ & $\begin{array}{l}\text { e PMA diz: Como está o } \\
2 \text { tempo? }\end{array}$ \\
\hline 17 & $\begin{array}{l}\text { PMA diz: Como está o } \\
\text { tempo? }\end{array}$ & $\begin{array}{l}\text { O aluno responde: } \\
\text { Ensolarado. }\end{array}$ & $\begin{array}{l}\text { PMA diz: Ensolarado? } \\
\text { Onde que você está } \\
\text { olhando? Você está } \\
\text { olhando Bauru? Onde está } \\
\text { Bauru? }\end{array}$ \\
\hline 18 & $\begin{array}{l}\text { PMA diz: Ensolarado? } \\
\text { Onde que você está } \\
\text { olhando? Você está } \\
\text { olhando Bauru? Onde está } \\
\text { Bauru? }\end{array}$ & O aluno não responde. & $\begin{array}{l}\text { PMA diz: Olha direito, } \\
\text { você olha aqui (e indica o } \\
\text { mapa) e não aponta nada. }\end{array}$ \\
\hline 19 & $\begin{array}{l}\text { PMA diz: Olha direito, } \\
\text { você olha aqui (e indica o } \\
\text { mapa) e não aponta nada. }\end{array}$ & $\begin{array}{ll}\mathrm{O} \text { aluno } & \text { encontra } \mathrm{e} \\
\text { responde: } & \text { parcialmente } \\
\text { nublado. } & \\
& \end{array}$ & $\begin{array}{l}\text { e PMA diz: Parcialmente } \\
\text { e nublado. PMA desenha o } \\
\text { símbolo na lousa e } \\
\text { continua: } E \text { a mínima } \\
\text { quantofoi? }\end{array}$ \\
\hline 20 & $\begin{array}{l}\text { PMA diz: Parcialmente } \\
\text { nublado. PMA desenha o } \\
\text { símbolo na lousa e } \\
\text { continua: E a mínima } \\
\text { quanto foi? }\end{array}$ & $\begin{array}{l}\mathrm{O} \text { aluno encontra } \\
\text { responde: } 18 .\end{array}$ & $\begin{array}{l}\text { e PMA escreve no quadro } \\
\text { desenhado na lousa a } \\
\text { temperatura mínima e } \\
\text { continua: E a máxima? }\end{array}$ \\
\hline 21 & $\begin{array}{l}\text { PMA escreve no quadro } \\
\text { desenhado na lousa a } \\
\text { temperatura mínima e } \\
\text { continua: E a máxima? }\end{array}$ & $\begin{array}{l}\text { O aluno encontra } \\
\text { responde: } 31 \text {. }\end{array}$ & $\begin{array}{l}\text { e PMA escreve no quadro } \\
\text { desenhado na lousa a } \\
\text { temperatura máxima. Neste } \\
\text { momento, PMA anda pela }\end{array}$ \\
\hline
\end{tabular}




\begin{tabular}{|c|c|c|c|}
\hline \# Evento & $\begin{array}{c}\text { Condições propostas por } \\
\text { PMA }\end{array}$ & Ações dos Alunos & $\begin{array}{l}\text { Ocorrências subsequentes do } \\
\text { professor }\end{array}$ \\
\hline & & & $\begin{array}{l}\text { sala, para ver como os } \\
\text { alunos estão copiando os } \\
\text { quadros da lousa. }\end{array}$ \\
\hline 22 & $\begin{array}{l}\text { PMA escreve no quadro } \\
\text { desenhado na lousa a } \\
\text { temperatura máxima. Neste } \\
\text { momento, PMA anda pela } \\
\text { sala, para ver como os } \\
\text { alunos estão copiando os } \\
\text { quadros da lousa. }\end{array}$ & $\begin{array}{l}\text { Enquanto PMA anda pela } \\
\text { sala, uma aluna pergunta: } \\
\text { Como olha o tempo? }\end{array}$ & $\begin{array}{l}\text { PMA diz: Olha aqui, onde } \\
\text { está Bauru? O que é isso } \\
\text { daqui, onde eu olho? PMA } \\
\text { está atendendo uma aluna } \\
\text { individualmente, e os } \\
\text { apontamentos "aqui" são } \\
\text { feitos diretamente no } \\
\text { recorte da aluna. }\end{array}$ \\
\hline 23 & $\begin{array}{l}\text { PMA diz: Olha aqui, onde } \\
\text { está Bauru? O que é isso } \\
\text { daqui, onde eu olho? PMA } \\
\text { está atendendo uma aluna } \\
\text { individualmente, e os } \\
\text { apontamentos "aqui" são } \\
\text { feitos diretamente no } \\
\text { recorte da aluna. }\end{array}$ & $\begin{array}{l}\text { A aluna responde: Aqui! A } \\
\text { aluna está apontando em } \\
\text { seu recorte as informações. }\end{array}$ & $\begin{array}{l}\text { PMA diz: Então, aqui, } \\
\text { onde que eu olho. Qual que } \\
\text { é igual aqui? PMA está } \\
\text { atendendo uma aluna } \\
\text { individualmente, e os } \\
\text { apontamentos "aqui" são } \\
\text { feitos diretamente no } \\
\text { recorte da aluna. }\end{array}$ \\
\hline 24 & $\begin{array}{l}\text { PMA diz: Então, aqui, } \\
\text { onde que eu olho. Qual que } \\
\text { é igual aqui? PMA está } \\
\text { atendendo uma aluna } \\
\text { individualmente, e os } \\
\text { apontamentos "aqui" são } \\
\text { feitos diretamente no } \\
\text { recorte da aluna. }\end{array}$ & $\begin{array}{l}\text { A aluna responde: Aqui! A } \\
\text { aluna está apontando em } \\
\text { seu recorte as informações. }\end{array}$ & $\begin{array}{l}\text { PMA diz: Então, olha aqui } \\
\text { e pronto. Com isso, PMA } \\
\text { finaliza o atendimento a } \\
\text { aluna e volta-se para a sala: } \\
\text { Depois do dia 2, que dia } \\
\text { que vem? }\end{array}$ \\
\hline 25 & $\begin{array}{l}\text { PMA diz: Então, olha aqui } \\
\text { e pronto. Com isso, PMA } \\
\text { finaliza o atendimento a } \\
\text { aluna e volta-se para a sala: } \\
\text { Depois do dia 2, que dia } \\
\text { que vem? }\end{array}$ & $\begin{array}{l}\text { Vários alunos respondem: } \\
3 \text {. }\end{array}$ & $\begin{array}{l}\text { PMA diz: Achou Bauru? } \\
\text { Como está o tempo? }\end{array}$ \\
\hline 26 & $\begin{array}{l}\text { PMA diz: Achou Bauru? } \\
\text { Como está o tempo? }\end{array}$ & $\begin{array}{l}\text { O aluno com o recorte } \\
\text { correspondente ao dia } 3 \\
\text { responde: Parcialmente } \\
\text { Nublado. }\end{array}$ & $\begin{array}{l}\text { PMA diz: Parcialmente } \\
\text { Nublado. PMA desenha o } \\
\text { símbolo correspondente na } \\
\text { lousa e continua: Qual o } \\
\text { mínimo? }\end{array}$ \\
\hline 27 & $\begin{array}{l}\text { PMA diz: Parcialmente } \\
\text { Nublado. PMA desenha o } \\
\text { símbolo correspondente na } \\
\text { lousa e continua: Qual o } \\
\text { mínimo? }\end{array}$ & $\begin{array}{l}\text { O aluno responde: } 20 . \\
\text { Outro aluno diz: Já tem } \\
\text { mais uma? Vai fazer da } \\
\text { aula inteira? }\end{array}$ & $\begin{array}{l}\text { PMA escreve no quadro da } \\
\text { lousa a temperatura mínima } \\
\text { e diz: E o máximo? }\end{array}$ \\
\hline 28 & $\begin{array}{l}\text { PMA escreve no quadro da } \\
\text { lousa a temperatura mínima } \\
\text { e diz: E o máximo? }\end{array}$ & O aluno responde: 33 . & $\begin{array}{l}\text { PMA escreve no quadro da } \\
\text { lousa a temperatura } \\
\text { máxima e diz: Depois, dia } \\
\text { 4. Onde está Bauru? Segue } \\
\text { a flexinha, o risquinho. } \\
\text { Como está o tempo? Olha } \\
\text { bem. Qual que é igual esse }\end{array}$ \\
\hline
\end{tabular}




\begin{tabular}{|c|c|c|c|}
\hline \# Evento & $\begin{array}{c}\text { Condições propostas por } \\
\text { PMA }\end{array}$ & Ações dos Alunos & $\begin{array}{l}\text { Dcorrências subsequentes do } \\
\text { professor }\end{array}$ \\
\hline & & & $\begin{array}{l}\text { aqui (pediu ao aluno que } \\
\text { olhasse o símbolo)? O que } \\
\text { está escrito aí? }\end{array}$ \\
\hline 29 & $\begin{array}{l}\text { PMA escreve no quadro da } \\
\text { lousa a temperatura } \\
\text { máxima e diz: Depois, dia } \\
\text { 4. Onde está Bauru? Segue } \\
\text { a flexinha, o risquinho. } \\
\text { Como está o tempo? Olha } \\
\text { bem. Qual que é igual esse } \\
\text { aqui (pediu ao aluno que } \\
\text { olhasse o símbolo)? O que } \\
\text { está escrito aí? }\end{array}$ & $\begin{array}{l}\text { O aluno responde: } \\
\text { Parcialmente Nublado. }\end{array}$ & $\begin{array}{l}\text { PMA diz: Continuou } \\
\text { Parcialmente Nublado. Em } \\
\text { seguida, desenha o símbolo } \\
\text { no quadro da lousa e diz: } \\
\text { Qual que é o mínimo e o } \\
\text { máximo? A mínima quanto } \\
\text { que é? }\end{array}$ \\
\hline 30 & $\begin{array}{l}\text { PMA diz: Continuou } \\
\text { Parcialmente Nublado. Em } \\
\text { seguida, desenha o símbolo } \\
\text { no quadro da lousa e diz: } \\
\text { Qual que é o mínimo e o } \\
\text { máximo? A mínima quanto } \\
\text { que é? }\end{array}$ & O aluno responde: 19. & $\begin{array}{l}\text { PMA escreve no quadro da } \\
\text { lousa a temperatura mínima } \\
\text { e diz: E o máximo? }\end{array}$ \\
\hline 31 & $\begin{array}{l}\text { PMA escreve no quadro da } \\
\text { lousa a temperatura mínima } \\
\text { e diz: E o máximo? }\end{array}$ & O aluno responde: 33 . & $\begin{array}{l}\text { PMA escreve no quadro da } \\
\text { lousa a temperatura } \\
\text { máxima diz: Depois do dia } \\
\text { 4, que dia que vem? }\end{array}$ \\
\hline 32 & $\begin{array}{l}\text { PMA escreve no quadro da } \\
\text { lousa a temperatura } \\
\text { máxima diz: Depois do dia } \\
\text { 4, que dia que vem? }\end{array}$ & $\begin{array}{l}\text { Vários alunos respondem: } \\
5 .\end{array}$ & $\begin{array}{l}\text { PMA pergunta: Como está } \\
\text { o tempo? }\end{array}$ \\
\hline 33 & $\begin{array}{l}\text { PMA pergunta: Como está } \\
\text { o tempo? }\end{array}$ & $\begin{array}{l}\mathrm{O} \text { aluno com o recorte } \\
\text { referente ao dia } 5 \text { responde: } \\
\text { Pancadas de Chuva. }\end{array}$ & $\begin{array}{l}\text { Assim que o aluno } \\
\text { responde, PMA desenha o } \\
\text { símbolo no quadro da lousa } \\
\text { e pergunta: Quanto que foi } \\
\text { a mínima? }\end{array}$ \\
\hline 34 & $\begin{array}{l}\text { Assim que o aluno } \\
\text { responde, PMA desenha o } \\
\text { símbolo no quadro da lousa } \\
\text { e pergunta: Quanto que foi } \\
\text { a mínima? }\end{array}$ & O aluno responde: 18. & $\begin{array}{l}\text { Assim que o aluno } \\
\text { responde, PMA escreve a } \\
\text { temperatura mínima no } \\
\text { quadro da lousa e pergunta: } \\
\text { E o máximo? }\end{array}$ \\
\hline 35 & $\begin{array}{l}\text { Assim que o aluno } \\
\text { responde, PMA escreve a } \\
\text { temperatura mínima no } \\
\text { quadro da lousa e pergunta: } \\
\text { E o máximo? }\end{array}$ & $\mathrm{O}$ aluno responde: 30 & $\begin{array}{l}\text { Assim que o aluno } \\
\text { responde, PMA escreve a } \\
\text { temperatura máxima no } \\
\text { quadro da lousa e pergunta: } \\
\text { Depois do dia 5? }\end{array}$ \\
\hline 36 & $\begin{array}{l}\text { Assim que o aluno } \\
\text { responde, PMA escreve a } \\
\text { temperatura máxima no } \\
\text { quadro da lousa e pergunta } \\
\text { Depois do dia 5? }\end{array}$ & $\begin{array}{l}\text { Alguns alunos respondem: } \\
\text { Vem } 6 .\end{array}$ & $\begin{array}{l}\text { PMA pergunta ao aluno } \\
\text { com } \quad \text { o } \\
\text { correspondente ao dia 6: } \\
\text { Olha aí [é o mapa dele] } \\
\text { como está o tempo? }\end{array}$ \\
\hline 37 & $\begin{array}{lcr}\text { PMA } & \text { pergunta } & \text { ao } \\
\text { com } & \text { o } & \text { recorte }\end{array}$ & $\begin{array}{l}\text { O aluno responde: } \\
\text { Pancadas de Chuva }\end{array}$ & $\begin{array}{llll}\text { Assim que } & \text { o } & \text { aluno } \\
\text { responde, PMA } & \text { desenha o }\end{array}$ \\
\hline
\end{tabular}




\begin{tabular}{|c|c|c|c|}
\hline \# Evento & $\begin{array}{c}\text { Condições propostas por } \\
\text { PMA }\end{array}$ & Ações dos Alunos & $\begin{array}{l}\text { Ocorrências subsequentes do } \\
\text { professor }\end{array}$ \\
\hline & $\begin{array}{l}\text { correspondente ao dia 6: } \\
\text { Olha aí [é o mapa dele] } \\
\text { como está o tempo? }\end{array}$ & & $\begin{array}{l}\text { símbolo no quadro da lousa } \\
\text { e pergunta: Quanto que foi } \\
\text { a mínima? }\end{array}$ \\
\hline 38 & $\begin{array}{l}\text { Assim que o aluno } \\
\text { responde, PMA escreve a } \\
\text { temperatura mínima no } \\
\text { quadro da lousa e pergunta: } \\
\text { Quanto que foi a mínima? }\end{array}$ & O aluno responde: 18 & $\begin{array}{l}\text { Assim que o aluno } \\
\text { responde, PMA escreve a } \\
\text { temperatura máxima no } \\
\text { quadro da lousa e pergunta: } \\
\text { E o máximo? }\end{array}$ \\
\hline 39 & $\begin{array}{l}\text { Assim que o aluno } \\
\text { responde, PMA escreve a } \\
\text { temperatura máxima no } \\
\text { quadro da lousa e pergunta: } \\
\text { E o máximo? }\end{array}$ & O aluno responde: 32 & $\begin{array}{l}\text { Assim que o aluno } \\
\text { responde, PMA escreve a } \\
\text { temperatura máxima no } \\
\text { quadro da lousa e pergunta: } \\
\text { O último que é dia? }\end{array}$ \\
\hline 40 & $\begin{array}{l}\text { Assim que o aluno } \\
\text { responde, PMA escreve a } \\
\text { temperatura máxima no } \\
\text { quadro da lousa e pergunta: } \\
\text { O último que é dia? }\end{array}$ & $\begin{array}{l}\text { Alguns alunos respondem: } \\
07 / 04\end{array}$ & $\begin{array}{l}\text { PMA pergunta: Como está } \\
\text { o tempo? }\end{array}$ \\
\hline 41 & $\begin{array}{l}\text { PMA pergunta: Como está } \\
\text { o tempo? }\end{array}$ & $\begin{array}{l}\text { O aluno responde: } \\
\text { Pancadas de Chuva }\end{array}$ & $\begin{array}{l}\text { Assim que o aluno } \\
\text { responde, PMA desenha o } \\
\text { símbolo no quadro da lousa } \\
\text { e pergunta: Quanto que foi } \\
\text { a mínima? }\end{array}$ \\
\hline 42 & $\begin{array}{l}\text { Assim que o aluno } \\
\text { responde, PMA desenha o } \\
\text { símbolo no quadro da lousa } \\
\text { e pergunta: Quanto que foi } \\
\text { a mínima? }\end{array}$ & O aluno responde: 17 & $\begin{array}{l}\text { Assim que o aluno } \\
\text { responde, PMA escreve a } \\
\text { temperatura máxima no } \\
\text { quadro da lousa e pergunta: } \\
\text { E a máxima? }\end{array}$ \\
\hline 43 & $\begin{array}{l}\text { Assim que o aluno } \\
\text { responde, PMA escreve a } \\
\text { temperatura máxima no } \\
\text { quadro da lousa e pergunta: } \\
\text { E a máxima? }\end{array}$ & O aluno responde: 28 & $\begin{array}{l}\text { PMA escreve no quadro da } \\
\text { lousa a temperatura } \\
\text { máxima e anda pela sala } \\
\text { para ver o caderno dos } \\
\text { alunos. Depois, diz: Então, } \\
\text { vamos ver, quantos dados } \\
\text { eu tenho em cada um } \\
\text { desses? (cada quadro que } \\
\text { PMA desenhou na lousa) }\end{array}$ \\
\hline
\end{tabular}

Tabela 25 - Tabela Unidades de Análises ou Hipóteses - H30 - PMA - UD - 02

\section{Descrição e análise dos eventos registrados}

PMA, ao finalizar a apresentação do conteúdo impresso no recorte de jornal entregue aos alunos, inicia uma nova atividade, com o objetivo de trabalhar a construção de um quadro que consiste em agrupar os dados sobre a previsão metereológica de cada data, como exemplifica a Figura 5: 


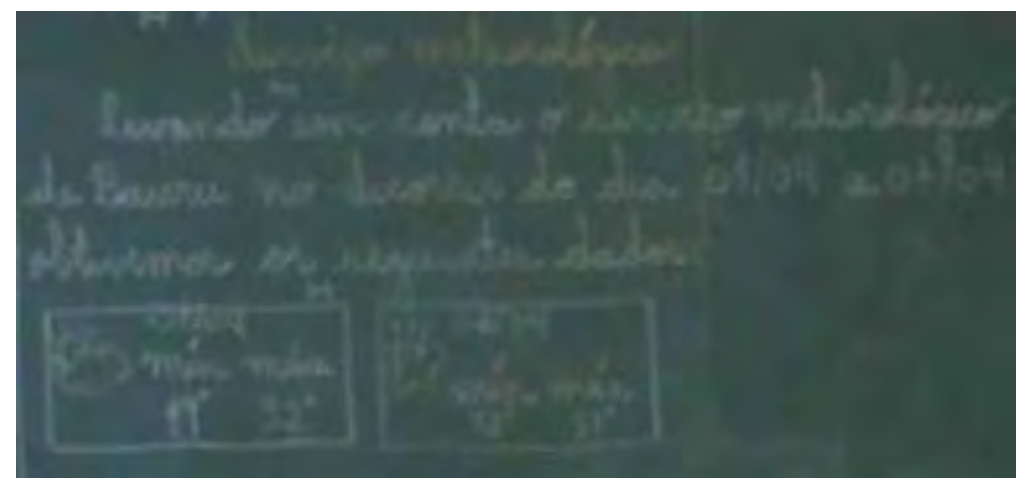

Figura 5 - Exemplo dos quadros que são montados por PMA na lousa.

Sendo assim, PMA propõe criar um quadro com os dados da previsão metereológica para cada data entre os dias 01/04 a 07/04. Em sequência, PMA solicita que o aluno com o recorte referente ao dia 01/04 leia as informações sobre a previsão de tempo e pergunta qual cidade levará em conta para construir o primeiro quadro. $\mathrm{O}$ aluno responde Bauru. Em seguida, PMA questiona o aluno sobre as condições do tempo em Bauru, no dia selecionado (01/04). O aluno responde com outra questão: "qual que é a temperatura que vai estar no dia primeiro?", mesmo PMA anteriormente dizendo que a resposta esperada poderia ser obtida da leitura da legenda.

Diante da questão do aluno, PMA confirma que é justamente o que gostaria que ele identificasse em seu mapa e, mesmo diante da questão do aluno, persiste na mesma orientação: ler a legenda. Com isso, o episódio se repete nos eventos \#4 e \#5, até que o aluno diz que não entendeu. Somente nos eventos \#6 e \#7, o aluno demonstra compreender o que PMA esperava como resposta, porém, sua compreensão se deu a partir de exemplos citados por PMA na elaboração de sua questão: “Está nublado, chuvoso, ensolarado?”. Em seguida, o aluno volta a sua atenção para a legenda e responde: "Parcialmente nublado".

No evento subseqüente (\#7), PMA elabora a seguinte questão para o aluno: "Como é parcialmente nublado?", diante da resposta do aluno e da ação subsequente de PMA, que desenha na lousa o símbolo referente à condição de tempo parcialmente nublado, é possível concluir que o aluno identificou corretamente o símbolo e que a resposta esperada por PMA para sua indagação era a descrição do mesmo.

Ao identificar o símbolo que representa as condições de tempo, PMA questiona novamente ao aluno sobre " $O$ que mais tem ẩ'. O aluno não responde à questão. Sobre o silêncio do aluno, várias hipóteses podem ser consideradas, sendo que uma delas poderia ser a não localização, por parte do aluno, das informações esperadas como resposta. Diante do 
silêncio do aluno, PMA induz a interpretação esperada por parte do mesmo: "Só tem o tempo? O que mais que tem? Tem duas temperaturas. Qual que tem? A primeira é mínima ou máxima?". Quando PMA localiza para o aluno a informação esperada, o aluno responde objetivamente: "Mínima". Cabem aqui novas hipóteses sobre a aprendizagem do aluno: (1) o aluno compreendeu o que significa temperatura mínima; (2) o aluno comportou-se de forma respondente às indagações de PMA; (3) o aluno utilizou o repertório disponível naquele momento para chegar à conclusão de que a resposta esperada era o termo mínima.

Porém, nos eventos subseqüentes (\#10 a 12), o aluno emite respostas apenas objetivas, cujas interpretações que poderiam levá-lo a desenvolver o repertório de comportamentos para observar foram realizadas por PMA. Esse episódio é mantido nos eventos posteriores. Com isso, é inconclusiva a aprendizagem do aluno sobre a interpretação dos dados por ele oralizados. Algumas das hipóteses que aqui podem ser elencadas são: (1) o aluno, mediante elaboração da interpretação das informações por PMA, compreendeu o caminho a ser percorrido para obter a resposta; (2) obteve a resposta diante de comportamentos evocados às indagações de PMA.

Portanto, a análise desta sequência de interação entre a prática de PMA e as respostas dos alunos indica a manutenção de um padrão no qual o procedimento do quadro ocorre mediante a produção de respostas discretas e pontuais dos alunos sobre questões específicas formuladas por PMA acerca de informações dispostas no material gráfico.

Nos eventos registrados aqui para a Habilidade H30, que preconiza a leitura e/ou a interpretação de informações contidas em gráficos, percebe-se que PMA tem uma prática de ensino, na qual ela subsidia o aluno com a interpretação esperada, restando a ele o papel de responder (evocar ou reconhecer), preencher, completar as interpretações previamente realizadas pela mesma.

Sendo assim, são várias as elaborações verbais de PMA sobre a interpretação e a leitura das legendas que mostraram-se condições insuficientes para garantir a leitura pelo aluno diante das instruções fornecidas por PMA.

Com isso, o que foi possível observar é que as respostas ocorrem mediante a exposição de alternativas por PMA, quando é possibilitado ao aluno escolher um dos itens ou complementar a falta de algum deles. Porém, ele não responde diante das indagações que PMA solicitava. Além disso, há ausência da nomeação da unidade de medida de temperatura, que poderia abordar outra habilidade descrita no SARESP - H22. Porém, não é conclusiva, dentro das práticas de ensino de PMA, se este era o foco de aprendizagem almejado, durante os registros aqui realizados. 
Como condição/práticas para o preenchimento em conjunto com os alunos dos quadros, PMA expõe indagações cujas respostas exigiriam a leitura de informações dispostas no material gráfico distribuídos aos alunos. As respostas dos alunos às indagações formuladas por PMA sugerem que:

(1) Restrições no controle que as instruções dispostas nas indagações exerciam sobre o comportamento de ler as informações dos alunos. Diante de questões que expressam indagações sobre propriedades ou informações do material gráfico, PMA prescinde de explicitação de dimensões que deveriam orientar as respostas dos alunos. Acertos consecutivos neste padrão de interações orais não justificariam a supressão progressiva de determinadas orientações para ampliar a busca mais autônoma pelas respostas ou informações necessárias para o preenchimento do quadro.

(2) Restrições no controle que a montagem dos quadros exercia sobre as informações fornecidas separadamente pelos alunos, ou seja, as práticas tornaram prováveis, de modo instável, respostas dos alunos que preenchiam os quadros sequêncialmente. Contudo, indagações que exigiam respostas sobre dimensões dos quadros produziram as mesmas respostas emitidas diante de indagações que exigiam a localização direta de informações no material gráfico disponível.

De modo complementar a tais análises, as respostas são pontuais e descrevem os conteúdos estudados, ou seja, quando as indagações foram expostas de modo conciso, sem explicitação de dimensões específicas do material gráfico, as respostas não apenas eram distintas do previsto, mas sugeriam relações de controle distintas daqueles estimados como predominantes por PMA. As respostas corretas ocorreram diante de questões que, oralmente, "orientam" os alunos, de modo direto e explícito, sobre as dimensões que devem ser consideradas para a emissão das respostas.

Em termos da análise da sequência na qual ocorreram tais interações, nitidamente a necessidade das "orientações orais na indagação" sugere restrições das práticas anteriores para estabelecer as relações de controle desejadas. Indagações elaboradas pelos alunos, contudo, sugerem que a emissão de tais respostas pontuais, não significa, de modo uniforme, que todos os alunos estejam respondendo de acordo com as relações de controle previstas. Indagação dos alunos e não as respostas dos alunos acabaram se constituindo em condições para modelagem, via interações orais, de relação de controle desejados, quando são as 
indagações explicitadas pelos alunos e não as respostas que impõem intervenção para modelagem de relação de controle. As respostas estão sendo admitidas, possivelmente, de modo incorreto, como critérios de relação de controle desejados.

Habilidade: H29. Ler e/ou interpretar informações e dados apresentados em tabelas e construir tabelas.

\begin{tabular}{|c|c|c|c|}
\hline \# Evento & Condições propostas por PMA & Ações dos Alunos & $\begin{array}{l}\text { Ocorrências subsequentes do } \\
\text { professor }\end{array}$ \\
\hline 1 & $\begin{array}{l}\text { PMA escreve no quadro da } \\
\text { lousa a temperatura máxima e } \\
\text { anda pela sala para ver o } \\
\text { caderno dos alunos. Depois, diz: } \\
\text { Então, vamos ver, quantos } \\
\text { dados eu tenho em cada um } \\
\text { desses? (cada quadro que PMA } \\
\text { desenhou na lousa) }\end{array}$ & $\begin{array}{l}\text { Vários alunos respondem } \\
\text { ao mesmo tempo: Dois. } \\
\text { Quatro. Três. }\end{array}$ & $\begin{array}{l}\text { PMA pergunta: Quem falou } \\
\text { dois? Quais são os dois? }\end{array}$ \\
\hline 2 & $\begin{array}{l}\text { PMA pergunta: Quem falou } \\
\text { dois? Quais são os dois? }\end{array}$ & $\begin{array}{l}\text { Um dos alunos responde: } \\
\text { Mínima e Máxima. }\end{array}$ & $\begin{array}{l}\text { PMA diz: } O \text { aluno falou que } \\
\text { tem a mínima e a máxima. } O \\
\text { Aluno X falou que aqui tem } \\
\text { dois dados: mínima e máxima. } \\
\text { A Aluna A falou que tem } 4 \\
\text { dados. Quais são os } 4 \text { dados? }\end{array}$ \\
\hline 3 & $\begin{array}{l}\text { PMA diz: } O \text { aluno falou que } \\
\text { tem a mínima e a máxima. } O \\
\text { Aluno X falou que aqui tem dois } \\
\text { dados: mínima e máxima. A } \\
\text { Aluna A falou que tem } 4 \text { dados. } \\
\text { Quais são os } 4 \text { dados? }\end{array}$ & $\begin{array}{l}\text { Outro aluno responde: } A \\
\text { mínima, máxima e o dia. }\end{array}$ & $\begin{array}{l}\text { PMA diz: Só que o dia é um } \\
\text { só. Mas, só se tem a mínima, a } \\
\text { máxima, o dia, o mês. Mas, o } \\
\text { dia e mês é o mesmo. Só tem } \\
\text { esses dados? }\end{array}$ \\
\hline 4 & $\begin{array}{l}\text { PMA diz: Só que o dia é um só. } \\
\text { Mas, só se tem a mínima, a } \\
\text { máxima, o dia, o mês. Mas, o } \\
\text { dia e mês é o mesmo. Só tem } \\
\text { esses dados? }\end{array}$ & $\begin{array}{l}\text { Outro aluno diz: Tem o } \\
\text { solzinho ali. }\end{array}$ & $\begin{array}{l}\text { PMA diz: Como que está o } \\
\text { tempo: se está chuvoso, } \\
\text { ensolarado, nublado. Então, } \\
\text { quantos dados têm aqui? o } \\
\text { dia, como que tava o tempo, o } \\
\text { mínimo e o máximo. Cada } \\
\text { retângulo na lousa tem } 4 \\
\text { dados. Pelo dia, o que eu } \\
\text { tenho? Eu tenho três } \\
\text { informações. Tenho como está } \\
\text { o tempo, a temperatura } \\
\text { mínima a máxima. Qual será } \\
\text { o primeiro dado que preciso } \\
\text { colocar na tabela? }\end{array}$ \\
\hline 5 & $\begin{array}{l}\text { PMA diz: Qual será o primeiro } \\
\text { dado que preciso colocar na } \\
\text { tabela? }\end{array}$ & Um aluno diz: $O$ dia. & $\begin{array}{l}\text { PMA diz: Olha lá já teve } \\
\text { gente que descobriu. Pode ser } \\
\text { o dia e o mês. Qual é o } \\
\text { primeiro dia? }\end{array}$ \\
\hline 6 & $\begin{array}{l}\text { MA diz: Olha lá já teve gente } \\
\text { que descobriu. Pode ser o dia e } \\
\text { o mês. Qual é o primeiro dia? }\end{array}$ & Um aluno diz: $01 / 04$ & $\begin{array}{l}\text { PMA diz: Quais são os outros } \\
\text { dados que preciso colocar na } \\
\text { tabela? }\end{array}$ \\
\hline
\end{tabular}




\begin{tabular}{|c|c|c|c|}
\hline \# Evento & Condições propostas por PMA & Ações dos Alunos & $\begin{array}{c}\text { Ocorrências subsequentes do } \\
\text { professor }\end{array}$ \\
\hline 7 & $\begin{array}{l}\text { PMA diz: Quais são os outros } \\
\text { dados que preciso colocar na } \\
\text { tabela? }\end{array}$ & $\begin{array}{l}\text { O aluno chama PMA em } \\
\text { sua mesa para tirar } \\
\text { dúvidas. A pergunta foi } \\
\text { feita em voz baixa. }\end{array}$ & $\begin{array}{l}\text { PMA diz: Não sei. O que seria } \\
\text { a legenda? E o tempo? Você } \\
\text { acha que é temperatura? Esse } \\
\text { tempo você colocaria de que } \\
\text { jeito? [Aluno e PMA } \\
\text { apontando para o caderno } \\
\text { dele, pois ela está atendendo } \\
\text { ele individualmente] }\end{array}$ \\
\hline 8 & $\begin{array}{l}\text { PMA diz: Não sei. O que seria } \\
\text { a legenda? E o tempo? Você } \\
\text { acha que é temperatura? Esse } \\
\text { tempo você colocaria de que } \\
\text { jeito? }\end{array}$ & $\begin{array}{l}\text { O aluno continua: } A \\
\text { temperatura? }\end{array}$ & $\begin{array}{l}\text { PMA pergunta: Que } \\
\text { temperatura? }\end{array}$ \\
\hline 9 & $\begin{array}{l}\text { PMA pergunta: Que } \\
\text { temperatura? }\end{array}$ & $\begin{array}{l}\mathrm{O} \text { mesmo aluno } \\
\text { responde: } A \text { mínima } e \\
\text { máxima. }\end{array}$ & $\begin{array}{l}\text { PMA: Como você colocaria a } \\
\text { mínima e máxima? }\end{array}$ \\
\hline 10 & $\begin{array}{l}\text { PMA: Como você colocaria a } \\
\text { mínima e máxima? }\end{array}$ & $\begin{array}{l}\text { O mesmo aluno responde } \\
\text { novamente: Não sei. }\end{array}$ & $\begin{array}{l}\text { PMA: Como você poderia } \\
\text { colocar ao invés de colocar } \\
\text { assim? [Aluno e PMA } \\
\text { apontando para o caderno } \\
\text { dele, pois ela está atendendo } \\
\text { ele individualmente] }\end{array}$ \\
\hline 11 & $\begin{array}{l}\text { PMA: Como você } \\
\text { colocar ao invés de colocar } \\
\text { assim? [Aluno e PMA } \\
\text { apontando para o caderno dele, } \\
\text { pois ela está atendendo ele } \\
\text { individualmente] }\end{array}$ & $\begin{array}{l}\text { O mesmo aluno responde } \\
\text { novamente: } \\
\text { Temperatura. }\end{array}$ & $\begin{array}{l}\text { PMA pergunta: Temperatura } \\
\text { o que? Quantas Temperaturas } \\
\text { eu tenho? [Aluno e PMA } \\
\text { apontando para o caderno } \\
\text { dele, pois ela está atendendo } \\
\text { ele individualmente] }\end{array}$ \\
\hline 12 & $\begin{array}{l}\text { PMA pergunta: Temperatura o } \\
\text { que? Quantas Temperaturas eu } \\
\text { tenho? [Aluno e PMA } \\
\text { apontando para o caderno dele, } \\
\text { pois ela está atendendo ele } \\
\text { individualmente] }\end{array}$ & $\begin{array}{l}\text { O mesmo aluno responde } \\
\text { novamente: } 7 \text {. }\end{array}$ & $\begin{array}{l}\text { PMA: } 7 ? \text { Eu tenho } 7 \\
\text { temperaturas? }\end{array}$ \\
\hline 13 & $\begin{array}{l}\text { PMA: } 7 ? \quad E u \quad \text { tenho } 7 \\
\text { temperaturas? }\end{array}$ & $\begin{array}{l}\text { O aluno responde então: } \\
2\end{array}$ & PMA pergunta: Quais são? \\
\hline 14 & PMA pergunta: Quais são? & $\begin{array}{l}\text { O aluno responde: } A \\
\text { mínima e máxima. }\end{array}$ & $\begin{array}{l}\text { PMA diz: Então! Você vai } \\
\text { colocar o que? [Aluno e PMA } \\
\text { apontando para o caderno } \\
\text { dele, pois ela está atendendo } \\
\text { ele individualmente] }\end{array}$ \\
\hline 15 & $\begin{array}{l}\text { PMA diz: Então! Você vai } \\
\text { colocar o que? [Aluno e PMA } \\
\text { apontando para o caderno dele, } \\
\text { pois ela está atendendo ele } \\
\text { individualmente] }\end{array}$ & $\begin{array}{l}\text { O aluno responde: } \\
\text { Temperatura máxima. }\end{array}$ & $\begin{array}{l}\text { PMA diz: Ao invés de por a } \\
\text { legenda, porque aqui é a } \\
\text { legenda do que? Então, como } \\
\text { que chama? O que representa } \\
\text { essa legenda? [Aluno e PMA } \\
\text { apontando para o caderno } \\
\text { dele, pois ela está atendendo } \\
\text { ele individualmente] }\end{array}$ \\
\hline 16 & PMA diz: Ao invés de por a & O aluno responde: Está & PMA: Então, seria condições \\
\hline
\end{tabular}




\begin{tabular}{|c|c|c|c|}
\hline \# Evento & Condições propostas por PMA & Ações dos Alunos & $\begin{array}{l}\text { Ocorrências subsequentes do } \\
\text { professor }\end{array}$ \\
\hline & $\begin{array}{l}\text { legenda, porque aqui é a } \\
\text { legenda do que? Então, como } \\
\text { que chama? O que representa } \\
\text { essa legenda? }\end{array}$ & nublado. & $\begin{array}{l}\text { do tempo. Aqui você põe a } \\
\text { legenda e não dá pra saber o } \\
\text { que é. [Aluno e PMA } \\
\text { apontando para o caderno } \\
\text { dele, pois ela está atendendo } \\
\text { ele individualmente] }\end{array}$ \\
\hline 17 & $\begin{array}{lll}\text { PMA pergunta: No dia } & 01 / 04, \\
\text { você só } & \text { tinha } & \text { essas } \\
\text { informações? } & & \\
\end{array}$ & $\begin{array}{l}\text { Um aluno responde: } \\
\text { Tinha mais. }\end{array}$ & $\begin{array}{l}\text { PMA pergunta: Quais são as } \\
\text { outras? }\end{array}$ \\
\hline 18 & $\begin{array}{l}\text { PMA pergunta: Quais são as } \\
\text { outras? }\end{array}$ & $\begin{array}{l}\text { Um aluno responde: } \\
\text { Temperatura. }\end{array}$ & $\begin{array}{l}\text { PMA pergunta: Onde você vai } \\
\text { colocar isso? }\end{array}$ \\
\hline 19 & $\begin{array}{l}\text { PMA pergunta: Onde você vai } \\
\text { colocar isso? }\end{array}$ & $\begin{array}{l}\text { O aluno mostra no } \\
\text { caderno. }\end{array}$ & $\begin{array}{l}\text { PMA diz: Aí, o que você vai } \\
\text { colocar aí? E agora que mais } \\
\text { você tem? } \\
\text { PMA chama uma aluna na } \\
\text { lousa para preencher a tabela. }\end{array}$ \\
\hline 20 & $\begin{array}{l}\text { PMA chama uma aluna na lousa } \\
\text { para preencher a tabela. }\end{array}$ & $\begin{array}{l}\text { A aluna preenche a } \\
\text { tabela na lousa referente } \\
\text { ao dia } 01 / 04 \text {. }\end{array}$ & $\begin{array}{l}\text { PMA diz que um aluno } \\
\text { preencheu a coluna das } \\
\text { Condições do Tempo com o } \\
\text { símbolo ou o texto escrito e } \\
\text { termina dizendo que não há } \\
\text { diferença entre os tipos de } \\
\text { dados, pois representam a } \\
\text { mesma coisa. Outro aluno vai } \\
\text { até a lousa. }\end{array}$ \\
\hline 21 & $\begin{array}{l}\text { PMA dita ao aluno que está na } \\
\text { lousa os dados para } \\
\text { preenchimento da tabela. }\end{array}$ & $\begin{array}{l}\text { O aluno escreve os dados } \\
\text { referentes ao dia 02/04. }\end{array}$ & $\begin{array}{l}\text { Novamente, PMA dita e } \\
\text { pergunta aos alunos sobre as } \\
\text { informações que devem ser } \\
\text { preenchidas nas colunas da } \\
\text { tabela. }\end{array}$ \\
\hline 22 & $\begin{array}{l}\text { PMA fala sobre a legenda, } \\
\text { dizendo que, para quem } \\
\text { preencheu a tabela com o } \\
\text { símbolo nas condições de } \\
\text { tempo, deveria escrever uma } \\
\text { legenda para que quem fosse ver } \\
\text { a tabela soubesse o que cada } \\
\text { símbolo significa. PMA toma o } \\
\text { caderno de uma aluna como } \\
\text { exemplo e diz que ela escreveu } \\
\text { a legenda. }\end{array}$ & & $\begin{array}{l}\text { PMA escreve na lousa a } \\
\text { próxima atividade a ser } \\
\text { realizada com a tabela, que é } \\
\text { montar um gráfico da } \\
\text { temperatura máxima. Essa } \\
\text { atividade é individual. }\end{array}$ \\
\hline
\end{tabular}

Tabela 26 - Tabela Unidades de Análises ou Hipóteses - H29 - PMA - UD - 02

\section{Descrição e análise dos eventos registrados}

Ao escrever os quadros sobre as condições de temperatura por data na lousa, PMA pergunta aos alunos quantos dados foram inseridos dentro de cada um deles. Os alunos 
respondem enumerando os dados de maneiras diferentes. PMA, então, evoca respostas dos alunos na tentativa de fazê-los descrever quais tipos de dados foram inseridos em cada quadro, no entendimento dos alunos, que responderam a questão.

Até o evento \#3, os alunos identificam três dados: a temperatura mínima, temperatura máxima e data. PMA induz, a partir dessas respostas, os alunos a observarem o símbolo que identifica o clima. Em seguida, faz a interpretação dos dados contidos nos quadros, dizendo aos alunos que cada quadro continha a data, as condições do tempo e as temperaturas mínimas e máximas.

Diante dessas respostas, PMA propõe uma nova atividade: criar uma tabela a partir dos conjuntos de informações contidos nos quadros (cada quadro será uma linha da tabela). O modelo utilizado foi transcrito a seguir:

\begin{tabular}{|c|c|c|c|}
\hline Dia & $\begin{array}{c}\text { Condições do } \\
\text { Tempo }\end{array}$ & Mínima & Máxima \\
\hline & & & \\
\hline
\end{tabular}

Tabela 27 - Modelo da tabela criada em aula - PMA

Em seguida, PMA desenha na lousa uma tabela com quatro colunas e, oralmente, orienta os alunos a preencherem a tabela em seus cadernos individualmente, enquanto anda pela sala de aula para fornecer instruções individuais.

A partir do evento \#20, PMA solicita a alguns alunos que preencham os dados por linha na lousa. Porém, PMA dita os dados que os alunos devem preencher e os alunos que sentem dificuldades em preenchê-las no caderno de forma individual, copiam a tabela da lousa.

O registro desses eventos mostra o mesmo padrão de interação já observado em análises anteriores: as respostas emitidas e que sustentam correspondências com a construção de tabelas ocorrem mediante questões específicas e pontuais, elaboradas por PMA.

Habilidade: H30. Ler e/ou interpretar informações e dados apresentados em gráficos e construir gráficos (particularmente gráficos de colunas).

\begin{tabular}{c|l|c|c} 
\# Evento & $\begin{array}{c}\text { Condições propostas por } \\
\text { PMA }\end{array}$ & Ações dos Alunos & $\begin{array}{c}\text { Ocorrências subsequentes do } \\
\text { professor }\end{array}$ \\
\hline 1 & PMA escreve na lousa a & Uma aluna pergunta: & PMA diz: Cada um pode fazer \\
& próxima atividade a ser & Pode fazer o gráfico na & do jeito que quiser e tem que \\
& realizada com a tabela, que & horizontal? & levar em conta a temperatura \\
& é montar um gráfico da & máxima. E não sei mais o quê \\
\hline
\end{tabular}




\begin{tabular}{|c|c|c|c|}
\hline \# Evento & $\begin{array}{c}\text { Condições propostas por } \\
\text { PMA }\end{array}$ & Ações dos Alunos & $\begin{array}{c}\text { Ocorrências subsequentes do } \\
\text { professor }\end{array}$ \\
\hline & $\begin{array}{l}\text { temperatura máxima. Essa } \\
\text { atividade é individual. }\end{array}$ & & $\begin{array}{l}\text { que vocês têm que levar em } \\
\text { consideração. Tem que levar } \\
\text { em consideração duas coisas: } \\
\text { a temperatura máxima e mais } \\
\text { uma coisa. }\end{array}$ \\
\hline 2 & $\begin{array}{l}\text { PMA diz: Cada um pode } \\
\text { fazer do jeito que quiser e } \\
\text { tem que levar em conta a } \\
\text { temperatura máxima. E } \\
\text { não sei mais o quê que } \\
\text { vocês têm que levar em } \\
\text { consideração. Tem que } \\
\text { levar em consideração } \\
\text { duas coisas: } a \\
\text { temperatura máxima e } \\
\text { mais uma coisa. }\end{array}$ & $\begin{array}{l}\text { Uma aluna diz: Ele não } \\
\text { sabe fazer, vai copiar do } \\
\text { livro. }\end{array}$ & $\begin{array}{l}\text { PMA diz: Copiar do livro? } \\
\text { Ele tem que tentar. Se a gente } \\
\text { não tenta, não pode falar que } \\
\text { não conseguiu. Só depois de } \\
\text { tentar, se não conseguiu tudo } \\
\text { bem. } \\
\text { PMA anda pela sala para ver } \\
\text { como os alunos estão criando } \\
\text { o gráfico. }\end{array}$ \\
\hline 3 & $\begin{array}{l}\text { PMA anda pela sala para } \\
\text { ver como os alunos estão } \\
\text { criando o gráfico. }\end{array}$ & $\begin{array}{l}\text { Um aluno pulou uma das } \\
\text { temperaturas máximas, } \\
\text { mas fez o gráfico de } \\
\text { barras corretamente, } \\
\text { levando em consideração } \\
\text { o dia e a temperatura } \\
\text { máxima daquele dia. }\end{array}$ & $\begin{array}{l}\text { PMA diz a ele que faltou uma } \\
\text { temperatura máxima e que ele } \\
\text { precisava prestar atenção. } \\
\text { Depois, continua: } O \text { que você } \\
\text { vai por aqui? Depois aqui? }\end{array}$ \\
\hline 4 & $\begin{array}{l}\text { PMA diz a ele que faltou } \\
\text { uma temperatura máxima } \\
\text { e que ele precisava prestar } \\
\text { atenção. Depois, continua: } \\
\text { O que você vai por aqui? } \\
\text { Depois aqui? }\end{array}$ & $\begin{array}{l}\text { O aluno respondeu em } \\
\text { voz baixa. }\end{array}$ & $\begin{array}{l}\text { Neste momento, PMA está na } \\
\text { carteira de outro aluno. PMA } \\
\text { diz: Isso é só a temperatura. } \\
\text { Aonde você vai por a } \\
\text { temperatura? E o outro? }\end{array}$ \\
\hline 5 & $\begin{array}{l}\text { Neste momento, PMA está } \\
\text { na carteira de outro aluno. } \\
\text { PMA diz: Isso é só a } \\
\text { temperatura. Aonde você } \\
\text { vai por a temperatura? E } \\
\text { o outro? }\end{array}$ & $\begin{array}{l}\text { O aluno está mostrando o } \\
\text { que fez no caderno e } \\
\text { falando com PMA. }\end{array}$ & $\begin{array}{l}\text { PMA diz: Um você vai por } \\
\text { isso (parece que PMA está } \\
\text { conversando com o aluno } \\
\text { sobre a temperatura). E o } \\
\text { outro? }\end{array}$ \\
\hline 6 & $\begin{array}{l}\text { PMA diz: Um você vai por } \\
\text { isso (parece que PMA está } \\
\text { conversando com o alunos } \\
\text { sobre a temperatura). E o } \\
\text { outro? }\end{array}$ & $\begin{array}{l}\text { O aluno continua } \\
\text { mostrando o que fez no } \\
\text { caderno e falando com } \\
\text { PMA. }\end{array}$ & $\begin{array}{l}\text { PMA diz: Você tem que ver } \\
\text { onde colocar. Dos dois jeitos } \\
\text { está certo. }\end{array}$ \\
\hline 7 & $\begin{array}{l}\text { PMA diz: Você tem que } \\
\text { ver onde colocar. Dos dois } \\
\text { jeitos está certo. }\end{array}$ & $\begin{array}{l}\text { O aluno está falando com } \\
\text { PMA em voz baixa. }\end{array}$ & $\begin{array}{l}\text { PMA pergunta: Mas, o que } \\
\text { você vai colocar no gráfico? } \\
\text { O que você tem que colocar } \\
\text { no gráfico? o que está } \\
\text { faltando colocar no gráfico? } \\
\text { A temperatura o que? }\end{array}$ \\
\hline 8 & $\begin{array}{l}\text { PMA pergunta: Mas, o que } \\
\text { você vai colocar no } \\
\text { gráfico? O que você tem } \\
\text { que colocar no gráfico? O }\end{array}$ & O aluno não responde. & $\begin{array}{lcr}\text { PMA } & \text { diz: } & \text { Temperatura } \\
\text { máxima. } & \text { Onde você vai } \\
\text { colocar } & \text { a temperatura } \\
\text { máxima? } & \text { Tem uns que estão }\end{array}$ \\
\hline
\end{tabular}




\begin{tabular}{|c|c|c|c|}
\hline \# Evento & $\begin{array}{c}\text { Condições propostas por } \\
\text { PMA }\end{array}$ & Ações dos Alunos & $\begin{array}{c}\text { Ocorrências subsequentes do } \\
\text { professor }\end{array}$ \\
\hline & $\begin{array}{l}\text { que está faltando colocar } \\
\text { no gráfico? A temperatura } \\
\text { o que? }\end{array}$ & & terminando. \\
\hline 9 & $\begin{array}{l}\text { PMA diz: Temperatura } \\
\text { máxima. Onde você vai } \\
\text { colocar a temperatura } \\
\text { máxima? Tem uns que } \\
\text { estão terminando. }\end{array}$ & $\begin{array}{l}\text { Um aluno responde: } E u \\
\text { terminei. }\end{array}$ & $\begin{array}{l}\text { PMA: Vai até onde? Tá vendo } \\
\text { como você conseguiu? Presta } \\
\text { atenção, só a gente tentando } \\
\text { fazer, é que vamos conseguir. } \\
\text { Dá pra fazer de dois jeitos o } \\
\text { gráfico. Aluno X, dizpra gente } \\
\text { o que você colocou aqui } \\
\text { embaixo. }\end{array}$ \\
\hline 10 & 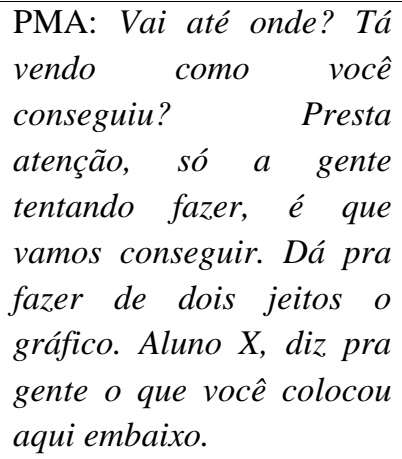 & $\begin{array}{l}\text { O aluno } \mathrm{X} \text { responde: } \mathrm{Os} \\
\text { números! }\end{array}$ & $\begin{array}{l}\text { PMA: Presta atenção. Ele } \\
\text { colocou aqui embaixo os } \\
\text { números. Em seguida, PMA } \\
\text { chama o aluno até a lousa para } \\
\text { que ele escreva a temperatura } \\
\text { máxima do dia 01/04. Depois, } \\
\text { chama a próxima aluna para } \\
\text { preencher a temperatura } \\
\text { máxima do dia 02/04. }\end{array}$ \\
\hline 11 & $\begin{array}{l}\text { PMA: Presta atenção. Ele } \\
\text { colocou aqui embaixo os } \\
\text { números. Em seguida, } \\
\text { PMA chama o aluno até a } \\
\text { lousa para que ele escreva } \\
\text { a temperatura máxima do } \\
\text { dia 01/04. Depois, chama a } \\
\text { próxima aluna para } \\
\text { preencher a temperatura } \\
\text { máxima do dia } 02 / 04 \text {. }\end{array}$ & $\begin{array}{l}\text { A aluna escreve na lousa } \\
\text { a temperatura do dia } \\
\text { 02/04, criando o gráfico } \\
\text { de barras na horizontal. }\end{array}$ & $\begin{array}{l}\text { PMA pergunta se a aluna } \\
\text { acertou para toda a turma. }\end{array}$ \\
\hline 12 & $\begin{array}{l}\text { PMA pergunta se a aluna } \\
\text { acertou para toda a turma. }\end{array}$ & $\begin{array}{l}\text { Alguns alunos falaram } \\
\text { sim e outros, que não. }\end{array}$ & $\begin{array}{l}\text { PMA, então, continua } \\
\text { chamando os alunos para } \\
\text { desenhar as barras do gráfico } \\
\text { referentes às temperaturas, dia } \\
\text { por dia. }\end{array}$ \\
\hline
\end{tabular}

Tabela 28 - Tabela Unidades de Análises ou Hipóteses - H30 - PMA - UD - 02

\section{Descrição e análise dos eventos registrados}

Após criar a tabela, PMA propõe a criação de um gráfico, com a seguinte atividade: Monte um gráfico levando em conta a temperatura máxima obtida durante o dia 01/04 até 07/04. Esse gráfico é do tipo Gráfico de Barras (Colunas), no qual o eixo X foi representado pela data e o eixo Y pela temperatura, como exemplifica a imagem a seguir: 


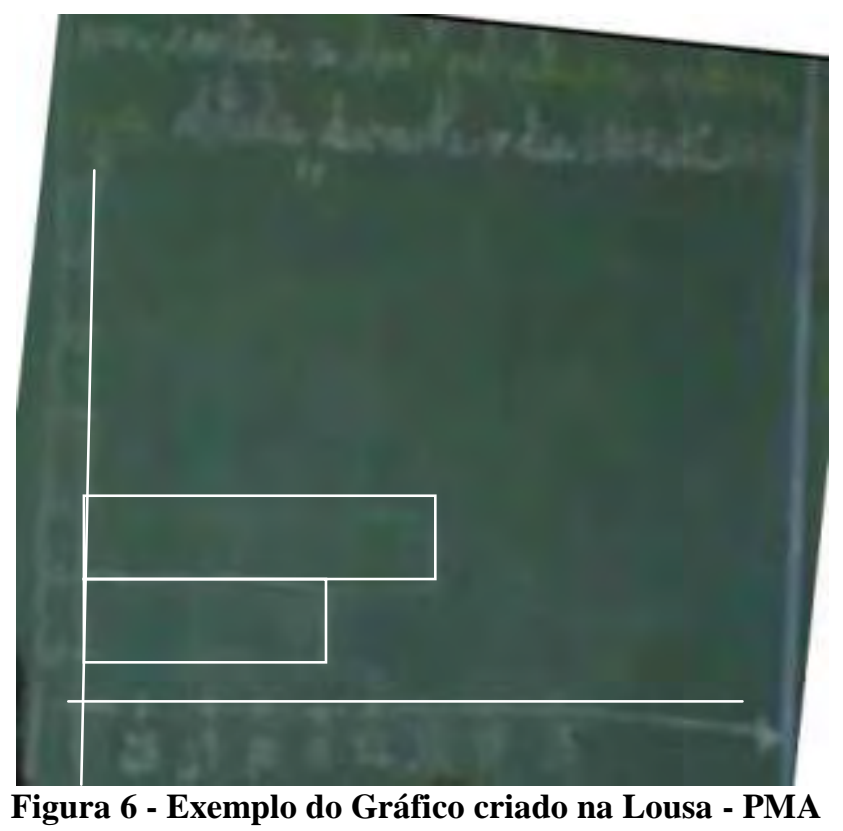

PMA solicita para que os alunos utilizem a temperatura máxima no eixo Y.

Enquanto os alunos construíam o gráfico no caderno, PMA andava pela sala de aula para atendê-los individualmente e, a partir do evento \# 10, após ter desenhado os eixos do gráfico na lousa, solicita que alguns alunos desenhem a barra referente à temperatura máxima das datas, nas sequências dos dias entre 01 e 07 de abril.

Mediante aos registros efetuados para esta habilidade, foram identificadas duas respostas dos alunos privilegiadas:

(1) A resposta de construção/elaboração de um sistema gráfico, ou seja, de plotar os dados da tabela em um eixo cartesiano;

(2) A resposta de descrever as variáveis expressas nos eixos X e Y do gráfico.

As práticas de ensino de PMA mesclaram condições que exigiam as duas respostas de modo praticamente simultâneo. Porém, as interações registradas parecem indicar uma relativa independência entre ambas. Isto posto é importante destacar dois aspectos sobre as práticas de ensino de PMA:

(1) As condições ou práticas dispostas para emissão de duas respostas previstas prescindiam da exploração de relatos dos alunos que pudessem sugerir ou indicar descrições das informações que seriam expressas no gráfico preenchido, ou seja, a análise seqüencial das interações permite constatar que as práticas de PMA prescindem de avaliação que permitissem descrever o produto final do gráfico preenchido em termos das informações às quais PMA 
daria acesso, em outros termos, de avaliação que permitiriam os alunos relatar o objetivo da construção do gráfico considerando as informações que o mesmo tornaria acessível. Caracterização por indagações sucessivas sobre informações pontuais tornando difícil de avaliar em que extensão tal padrão de interação garantiu aos alunos informações sobre os objetivos do gráfico.

(2) A ausência de respostas descritivas das informações dispostas em um dos eixos do gráfico, diante de questões que solicitava o nome de tal variável e, não os objetivos do gráfico em termos das informações que se tornariam acessíveis, ocasionou a produção de respostas previstas por PMA e não alteração no modo de perguntar.

\subsubsection{Etapa 3 - Síntese das análises obtidas na Etapa 2 da UD - 02 de PMA}

Novamente, diante da Proposta Curricular do Estado de São Paulo para o Ensino Fundamental - Ciclo I, PMA em sua proposta de atividade, independentemente das condições favorecidas nas interações registradas durante a análise das aulas, aborda alguns dos conteúdos que oportunizam aos alunos desenvolverem habilidades e competências previstas na matriz da proposta curricular relacionadas à resolução construção de gráfico. Adiante, seguem as análises das interações de PMA promovidas aos alunos.

As interações registradas para UD - 02 mostram que PMA expõe oralmente a atividade a ser realizada e que, praticamente, todas as condições criadas para as interações ocorreram entre professor e aluno.

Reincidentemente, é possível observar que, embora em outro contexto de atividade, as práticas de ensino de PMA utilizam as mesmas estratégias já registradas na UD01, evidenciando um padrão de comportamento da professora que cria condições favoráveis aos alunos a emitirem comportamentos predominantemente sob a forma de respostas orais e escritas para indagações formuladas pela professora.

O que foi possível observar é que durante a análise, nos três grandes passos da atividade, sendo (a) o agrupamento dos dados no mapa em quadros; (b) a construção das tabelas, mediante aos quadros; (c) a construção do gráfico, PMA elabora as análises que deveriam ser feitas pelos alunos, deixando a eles a tarefa de localizar dados e ditá-los. Com isso, nas interações registradas ficou evidente que a estratégia de PMA estava focada em elaborações de questões que direcionaram os alunos para as dimensões estimadas relevantes 
pela professora, o que restringiu a exploração pelos alunos sobre as características da ilustração fornecida e, por sua vez, impôs a eles, a interpretação de PMA. Sendo assim, PMA elimina as possibilidades de os alunos emitirem respostas ou comportamentos consistentes com as habilidades envolvidas, restringindo a amplitude daqueles repertórios explorados com as práticas disponibilizadas. Novamente, PMA prescinde de descrição e de investigação de relação de controle possivelmente relacionadas com a resposta emitida, sendo esta correta ou não.

Ainda pelos registros das interações, é evidente que as condições de participação dos alunos são restritas: eles têm a função de ditar os dados para PMA, que cria tanto o quadro, quanto a tabela na lousa, o que também evidencia a cópia posterior e contingente ao término da exposição/ resolução dos exercícios por PMA. Diante deste contexto, PMA prescindiu de medidas de compreensão que poderiam sugerir controles adicionais para o comportamento de copiar.

Deste modo, ao restringir as condições de participação dos alunos e favorecer o fornecimento das soluções dos exercícios, é evidente que as interações registradas nas aulas da UD - 02 tornam os procedimentos utilizados por PMA inconclusivos no que diz respeito às medidas dos possíveis efeitos de suas ações sobre os repertórios previstos para os respectivos conteúdos curriculares. 


\subsection{Resultados de PRA - UD - 01}

A Unidade Didática - 01 de PRA tem como tema principal a Teorema de Pitágoras: demonstração e interpretação.

\subsubsection{Etapa 1 - Caracterização das habilidades diante das práticas de ensino de PRA}

\begin{tabular}{|c|c|c|c|c|c|c|c|c|c|c|c|c|}
\hline \multirow{2}{*}{$\begin{array}{l}\text { Tempo em } \\
\text { minutos }\end{array}$} & \multicolumn{3}{|c|}{ Tema 1} & \multicolumn{3}{|c|}{ Tema 2} & \multicolumn{3}{|c|}{ Tema 3} & \multicolumn{3}{|c|}{ Tema 4} \\
\hline & GI & GII & GIII & GI & GII & GIII & GI & GII & GIII & GI & GII & GIII \\
\hline $1 ’ 30$ & & & & & & & & H39 & & & & \\
\hline 9'44 & & & H19 & & & & & & & & & \\
\hline $11{ }^{\prime} 40$ & & & & & $\mathrm{H} 24$ & & & & & & & \\
\hline 13 '27 & & & H19 & & & & & & & & & \\
\hline
\end{tabular}

Tabela 29 - Tabela de Caracterização das Habilidades - UD 01 - PRA

Ao assistir a Unidade Didática 01 de PRA, a pesquisadora vinculou as práticas de ensino e de avaliação observadas nas gravações com as habilidades inseridas na tabela 29. As habilidades relacionadas estão da seguinte forma descritas no SARESP (GOVERNO DO ESTADO DE SÃO PAULO, 2009a):

- H19. Resolver problemas que envolvam equações do $2^{\circ}$ grau.

- H24. Identificar propriedades de triângulos pela comparação de medidas de lados e ângulos.

- H39. Resolver problemas que envolvam o cálculo de área de figuras planas.

Posta a tabela 29, a seguir, foram descritas e analisadas as interações registradas considerando cada uma das habilidades vinculadas, levando em consideração a sequência na qual as interações ocorreram. No transcurso da aula, as exposições orais dos alunos e dos professores envolvidos nos episódios de gravação considerados foram destacadas em itálico. 


\subsubsection{Etapa 2 - Descrição das habilidades a partir das interações registradas e Análise das interações correspondentes às habilidades vinculadas}

Habilidade: H39. Resolver problemas que envolvam o cálculo de área de figuras planas.

\begin{tabular}{|c|c|c|c|}
\hline \# Evento & Condições propostas por PRA & Ações dos Alunos & $\begin{array}{l}\text { Eventos ou Ocorrências } \\
\text { subsequentes do professor }\end{array}$ \\
\hline 1 & $\begin{array}{l}\text { PRA desenha, na lousa, duas } \\
\text { malhas quadriculadas formando } \\
\text { o ângulo reto e diz: A situação } \\
\text { ideal é essa: um quadrado de } 8 \\
\text {... }\end{array}$ & $\begin{array}{l}\text { Um aluno complementa: } \\
\text { por } 8 \text {. }\end{array}$ & $\begin{array}{l}\text { PRA diz: Por } 8 \text {. E o outro } \\
\text { quadrado de } 6 . \text { Muito } \\
\text { bem! Isso é a primeira } \\
\text { coisa que você tem, } \\
\text { desenhar esse quadrado e } \\
\text { esse e depois, ligar o } \\
\text { vértice desse com esse. Aí, } \\
\text { eu pedi para que vocês } \\
\text { recortassem } \\
\text { quadrado esse } \\
\text { recortassem aqui } e \\
\text { quadrado. o que vocês } \\
\text { fizeram com isso daqui? } \\
\text { Esse aqui... }\end{array}$ \\
\hline
\end{tabular}

Figura 7 - Exemplo do modelo utilizado por PRA

\begin{tabular}{llll}
\hline PRA diz: O que vocês fizeram Um aluno: colocou em & PRA diz: Colocou esse \\
& com isso daqui? Recortou ... cima do triangulo. & aqui colocamos aqui. \\
& Esse aqui e recortasse esse & & Então, vamos ver se o meu \\
& quadrado [PRA faz referência & & vai dar aqui. Foi mais ou \\
& aos quadrados rosa e amarelo & & menos isso que aconteceu? \\
& acima exemplificado] & Foi? Ficou assim? \\
\hline
\end{tabular}

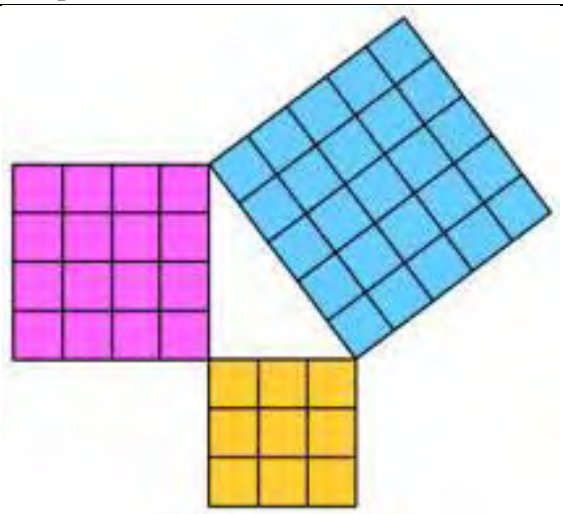

Figura 8 - Exemplo do modelo alterado, depois dos recortes - PRA

$\begin{array}{lll}\text { PRA diz: Foi mais ou menos Um aluno: Foi. } & \text { PRA diz: Aí, esse aqui, o } \\ \text { isso que aconteceu? Foi? Ficou } & \text { que vamos fazer com ele? } \\ \text { assim? } & \end{array}$




\begin{tabular}{c|l|c} 
\# Evento & Condições propostas por PRA & Ações dos Alunos \\
\hline 4 & $\begin{array}{l}\text { PRA diz: Aí, esse aqui, o que } \\
\text { vamos fazer com ele? }\end{array}$
\end{tabular}

Eventos ou Ocorrências subsequentes do professor

PRA diz: A tira ficou com 2 por 6. A tira tinha 6 de comprimento e 2 de largura. Aí, nós colocamos uma tira aqui. [Aqui, refere-se a lateral do quadrado formado sob a base da hipotenusa] $E a$ outra tira?

\begin{tabular}{|c|c|c|c|}
\hline 5 & $\begin{array}{l}\text { PRA diz: A tira ficou com } 2 \text { por } \\
\text { 6. A tira tinha } 6 \text { de comprimento } \\
e \quad 2 \text { de largura. Aí, nós } \\
\text { colocamos uma tira aqui. [Aqui, } \\
\text { refere-se a lateral do quadrado } \\
\text { formado sob a base da } \\
\text { hipotenusa] E a outra tira? }\end{array}$ & $\begin{array}{l}\text { Um aluno responde: Lá em } \\
\text { cima. }\end{array}$ & $\begin{array}{l}\text { PRA diz: Lá em cima. A } \\
\text { outra tira que sobrou nos } \\
\text { cortamos, } 4 \text { quadradinhos } \\
\text { separados. Os de } 4 \text { nos } \\
\text { colocamos aqui [e mostra } \\
\text { na lousa o vértice à direita } \\
\text { do quadrado formado], e o } \\
\text { outro que ficou } 2 x 4 \text {, } \\
\text { colocamos aqui. Os dois } \\
\text { quadrados que vocês } \\
\text { tinham, sobrou algum } \\
\text { pedacinho parafora? }\end{array}$ \\
\hline 6 & $\begin{array}{l}\text { PRA diz: Lá em cima. A outra } \\
\text { tira que sobrou nos cortamos, } 4 \\
\text { quadradinhos separados. Os de } \\
4 \text { nos colocamos aqui [e mostra } \\
\text { na lousa o vértice à direita do } \\
\text { quadrado formado], e o outro } \\
\text { que ficou } 2 \times 4 \text {, colocamos aqui. } \\
\text { Os dois quadrados que vocês } \\
\text { tinham, sobrou algum } \\
\text { pedacinho parafora? }\end{array}$ & $\begin{array}{l}\text { Alguns alunos respondem: } \\
\text { Não. }\end{array}$ & $\begin{array}{l}\text { PRA diz que os dois } \\
\text { quadrados (os que formam } \\
\text { o ângulo reto) estão } \\
\text { contidos na terceira malha, } \\
\text { que forma a hipotenusa. } \\
\text { Em seguida, conta todos } \\
\text { os quadrados contidos na } \\
\text { malha, cujo lado } \\
\text { representava a hipotenusa. } \\
\text { Depois disso, conta os } \\
\text { quadrados das outras duas } \\
\text { malhas e continua: O } \\
\text { quadrado cor-de-rosa não } \\
\text { modificou. Então, aqui tem } \\
64 \text { quadradinhos cor-de- } \\
\text { rosa. E aqui tem } 36 \\
\text { quadradinhos amarelos. } \\
\text { Ao todo, está dando 100. } \\
\text { Se eu contar aqui 1, 2, } 3, \ldots \\
9 \text { ? }\end{array}$ \\
\hline 7 & $\begin{array}{l}\text { Depois disso, conta os } \\
\text { quadrados das outras duas } \\
\text { malhas e continua: } O \text { quadrado } \\
\text { cor-de-rosa não modificou. } \\
\text { Então, aqui tem } 64 \\
\text { quadradinhos cor-de-rosa. E } \\
\text { aqui tem 36 quadradinhos } \\
\text { amarelos. Ao todo, está dando } \\
\text { 100. Se eu contar aqui } 1,2,3, \ldots \\
9 ?\end{array}$ & $\begin{array}{l}\text { Alguns alunos respondem: } \\
10 .\end{array}$ & $\begin{array}{l}\text { PRA diz: Se eu contar } \\
\text { aqui } 1,2,3, \ldots 9 ?\end{array}$ \\
\hline 8 & $\begin{array}{l}\text { PRA diz: Se eu contar aqui } 1,2 \text {, } \\
3, \ldots 9 \text { ? }\end{array}$ & $\begin{array}{l}\text { Alguns alunos respondem: } \\
10 .\end{array}$ & PRA: $10 \times 10 ?$ \\
\hline 9 & PRA: $10 \times 10 ?$ & $\begin{array}{l}\text { Alguns alunos respondem: } \\
100 .\end{array}$ & 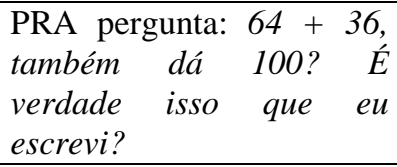 \\
\hline 10 & PRA pergunta: $64+36$, também & Alguns alunos respondem: & PRA: $10 \times 10$, eu posso \\
\hline
\end{tabular}




\begin{tabular}{|c|c|c|c|}
\hline \# Evento & Condições propostas por PRA & Ações dos Alunos & $\begin{array}{l}\text { Eventos ou Ocorrências } \\
\text { subsequentes do professor }\end{array}$ \\
\hline & $\begin{array}{l}\text { dá 100? É verdade isso que eu } \\
\text { escrevi? }\end{array}$ & $\dot{E}$. & escrever assim: $10^{2} ?$ \\
\hline 11 & $\begin{array}{l}\text { PRA: } 10 \times 10 \text {, eu posso escrever } \\
\text { assim: } 10^{2} \text { ? }\end{array}$ & $\begin{array}{l}\text { Alguns alunos respondem: } \\
\text { Pode. }\end{array}$ & $\begin{array}{l}\text { PRA: } 64 \text {, veio daqui, } 8 \times 8 \text {. } \\
36 \text {, veio daqui: } 6 \times 6 \text {. Oito } \\
\text { vezes Oito eu posso } \\
\text { escrever assim? Oito ao } \\
\text { quadrado? }\end{array}$ \\
\hline 12 & $\begin{array}{l}\text { PRA: } 64 \text {, veio daqui, } 8 \times 8.36 \text {, } \\
\text { veio daqui: } 6 x \text {. Oito vezes } \\
\text { Oito eu posso escrever assim? } \\
\text { Oito ao quadrado? }\end{array}$ & $\begin{array}{l}\text { Alguns alunos respondem: } \\
\text { Pode. }\end{array}$ & $\begin{array}{l}\text { PRA: } 6 \times 6 \text {, pode escrever } \\
6 \text { ao quadrado? }\end{array}$ \\
\hline 13 & $\begin{array}{l}\text { PRA: } 6 \times 6 \text {, pode escrever } 6 \text { ao } \\
\text { quadrado? }\end{array}$ & $\begin{array}{l}\text { Alguns alunos respondem: } \\
\text { Pode. }\end{array}$ & $\begin{array}{l}\text { PRA diz: Isso é o Teorema } \\
\text { de Pitágoras. Foi isso que } \\
\text { Pitágoras descobriu que } \\
\text { funciona em todo } \\
\text { triângulo retângulo. Como } \\
\text { eu sei que esse triângulo é } \\
\text { retângulo? Como eu } \\
\text { construí na malha } \\
\text { quadriculada, o ângulo do } \\
\text { cantinho do quadrado é? }\end{array}$ \\
\hline 14 & $\begin{array}{l}\text { PRA diz: Isso é o Teorema de } \\
\text { Pitágoras. Foi isso que } \\
\text { Pitágoras descobriu que } \\
\text { funciona em todo triângulo } \\
\text { retângulo. Como eu sei que esse } \\
\text { triângulo é retângulo? Como eu } \\
\text { construí na malha } \\
\text { quadriculada, o ângulo do } \\
\text { cantinho do quadrado é? }\end{array}$ & $\begin{array}{l}\text { Alguns alunos respondem: } \\
90 \text { graus. }\end{array}$ & $\begin{array}{l}\text { PRA diz: Então, está } \\
\text { garantido que o triângulo, } \\
\text { esse triângulo branco, ele } \\
\text { é triângulo retângulo. E o } \\
\text { que é que eu descobri? } \\
\text { Essa medida que é 6, se eu } \\
\text { elevar ao quadrado e } \\
\text { somar. Vai dar a mesma } \\
\text { coisa da medida que eu } \\
\text { nem sabia quanto que era } \\
e \text { quando eu colei, eu } \\
\text { descobri era lo. Esse } \\
\text { quadrado e esse aqui, } \\
\text { quando somados, vão dar } \\
\text { o valor da medida de } \\
\text { loxlo. Essa foi a } \\
\text { descoberta da Pitágoras. }\end{array}$ \\
\hline 15 & $\begin{array}{l}\text { PRA diz: Então, está garantido } \\
\text { que o triângulo, esse triângulo } \\
\text { branco, ele é triângulo } \\
\text { retângulo. E o que é que eu } \\
\text { descobri? Essa medida que é } 6 \text {, } \\
\text { se eu elevar ao quadrado e } \\
\text { somar. Vai dar a mesma coisa } \\
\text { da medida que eu nem sabia } \\
\text { quanto que era e quando eu } \\
\text { colei, eu descobri era 10. Esse } \\
\text { quadrado e esse aqui, quando } \\
\text { somados, vão dar o valor da } \\
\text { medida de 10xlo. Essa foi a } \\
\text { descoberta da Pitágoras. }\end{array}$ & $\begin{array}{l}\text { Um aluno pergunta: } P R A \text {, } \\
\text { eu consigo descobrir o } \\
q u \hat{e} ?\end{array}$ & $\begin{array}{l}\text { PRA responde: Isso aqui } \\
\text { faz você descobrir o que? } \\
\text { Esse aqui é o triângulo } \\
\text { retângulo, essa medida } \\
\text { aqui é três, essa medida } \\
\text { aqui é quatro, eu não sei } \\
\text { quanto é essa. Eu quero } \\
\text { saber. Descobre essa } \\
\text { medida para mim. } \\
\text { PRA explica a sentença do } \\
\text { Teorema de Pitágoras e } \\
\text { continua: O que eu faço } \\
\text { agora para substituir? } \\
\text { Isso aqui tem cara do quêe } \\
\text { que a gente já conhece? }\end{array}$ \\
\hline
\end{tabular}

Tabela 30 - Tabela Unidades de Análises ou Hipóteses - H39 - PRA - UD - 01 


\section{Descrição e análise dos eventos registrados}

PRA inicia a aula desenhando na lousa três malhas quadriculadas para demonstrar o Teorema de Pitágoras, por meio do cálculo de área das malhas desenhadas. Após terminar o desenho na lousa, PRA conta junto aos alunos quantos quadrados formavam cada malha desenhada, sem, contudo, associar os valores encontrados com o conceito de área.

Como parte da demonstração iniciada, PRA, então, pergunta à turma se os números obtidos nas contagens poderiam ser expressos em potência de 2, todos concordam (embora os alunos concordassem, na observação, não fica claro se eles compreenderam o por quê os números obtidos poderiam ser expressos desta forma - cálculo da área dos quadrados). Em seguida, PRA elabora a interpretação do Teorema de Pitágoras, dizendo que "isso" é o Teorema de Pitágoras, que "funciona" para todos os triângulos retângulos. Em seguida, PRA induz os alunos a identificarem o ângulo reto formado no triângulo retângulo.

Enquanto expõe oralmente a explicação, PRA elabora o raciocínio; realizando a interpretação para as ilustrações de modo independente de qualquer certificação de que os alunos estão acompanhando a observação de PRA em termos dos mesmos aspectos.

Ao finalizar sua explicação, um aluno pergunta o que se consegue descobrir com o Teorema de Pitágoras? Embora, na demonstração, PRA tenha completado a explicação sobre o cálculo dos lados do triângulo retângulo formado, parece não ter fícado claro para o aluno, que existe uma regularidade, ou seja, uma sentença que permitirá o mesmo cálculo dos lados do triângulo retângulo $\left(\mathrm{a}^{2}=\mathrm{b}^{2}+\mathrm{x}^{2}\right)$.

Diante da questão do aluno, PRA direciona sua explicação de forma a interpretar, pelo e para o aluno, o Teorema de Pitágoras. Com isso, as ações exibidas por PRA mostraram-se incompatíveis com repertórios de ensino que poderiam desenvolver comportamentos nos alunos que possibilitassem a interpretação e a generalização, ou seja, as respostas que, segundo PRA, consistiriam em medidas comportamentais de compreensão esperada dos alunos. Posto a sentença na lousa, PRA pergunta aos alunos qual o tipo de sentença foi representada (a resposta prevista era de $2^{\circ} \mathrm{Grau}$ ).

De acordo com os registros das contingências realizados como tratamento da habilidade observada, é possível verificar que as respostas dos alunos foram restritas a confirmações e informações de características que fornecem subsídios para a elaboração oral de interpretações sobre as propriedades de figuras geométricas por PRA.

Ainda que as respostas dos alunos sugiram o acompanhamento das interpretações realizadas por PRA, não fica claro se eles realmente conseguiram identificar as mesmas 
propriedades que PRA mencionou. Tal evidência pode ser observada mediante a questão posta por um dos alunos: "PRA, eu consigo descobrir o quê??". Perante esta questão, é possível supor que PRA prescindiu de esclarecimentos sobre os seus objetivos, ou seja, não foram expostas aos alunos informações prévias a respeito das motivações, justificativas para tais narrativas. Além disso, a indagação do aluno sugere que possivelmente seria necessário que PRA tomasse algumas ações que o levasse a ser capaz de relatar as propriedades de figuras geométricas, tais como:

(a) Fornecer explicitação sobre o problema que justificariam os cálculos e as descrições;

(b) Investigar os domínios, pelos alunos, dos repertórios relacionados com habilidades de GI, Tema I, como H19. Resolver problemas que envolvam equações do $2^{\circ}$ grau.

Habilidade: H19. Resolver problemas que envolvam equações do $2^{\circ}$ grau.

\begin{tabular}{|c|c|c|c|}
\hline \# Evento & $\begin{array}{c}\text { Condições propostas por } \\
\text { PRA }\end{array}$ & Ações dos Alunos & $\begin{array}{c}\text { Ocorrências subsequentes } \\
\text { do professor }\end{array}$ \\
\hline 1 & $\begin{array}{l}\text { PRA diz: } O \text { que eu faço } \\
\text { agora para substituir? } \\
\text { Isso aqui [aponta para a } \\
\text { lousa a equação] tem cara } \\
\text { do quê que a gente já } \\
\text { conhece? }\end{array}$ & $\begin{array}{l}\text { Um aluno responde: } \\
\text { Equação. }\end{array}$ & $\begin{array}{l}\text { PRA diz: Equação. De que } \\
\text { grau? }\end{array}$ \\
\hline 2 & $\begin{array}{l}\text { PRA diz: Equação. De que } \\
\text { grau? }\end{array}$ & $\begin{array}{l}\text { Um aluno responde: Do } \\
\text { segundo. }\end{array}$ & $\begin{array}{l}\text { PRA diz: Por que é de } \\
\text { segundo? }\end{array}$ \\
\hline 3 & $\begin{array}{l}\text { PRA diz: Por que é de } \\
\text { segundo? }\end{array}$ & 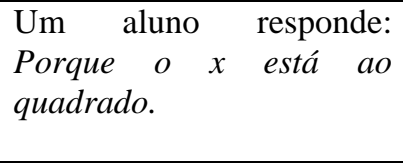 & $\begin{array}{l}\text { PRA confirma: Porque o } X \\
\text { está ao quadrado. Então, } \\
\text { vamos lá. Quatro ao } \\
\text { quadrado? }\end{array}$ \\
\hline 4 & $\begin{array}{l}\text { PRA confirma: Porque o } X \\
\text { está ao quadrado. Então, } \\
\text { vamos lá. Quatro ao } \\
\text { quadrado? }\end{array}$ & Um aluno responde: 16. & $\begin{array}{l}\text { PRA pergunta: } E \text { três ao } \\
\text { quadrado? Três vezes } \\
\text { três? }\end{array}$ \\
\hline 5 & $\begin{array}{l}\text { PRA pergunta: E três ao } \\
\text { quadrado? Três vezes } \\
\text { três? }\end{array}$ & Um aluno responde: 9. & $\begin{array}{l}\text { PRA pergunta: Quanto é } \\
16 \text { mais 9? }\end{array}$ \\
\hline 6 & $\begin{array}{l}\text { PRA pergunta: Quanto é } \\
16 \text { mais 9? }\end{array}$ & Um aluno responde: 25 . & $\begin{array}{l}\text { PRA diz: 25. E agora, que } \\
\text { pergunta que eu faço? }\end{array}$ \\
\hline 7 & $\begin{array}{l}\text { PRA diz: 25. E agora, que } \\
\text { pergunta que eu faço? }\end{array}$ & $\begin{array}{l}\text { Um aluno responde: Qual } \\
\text { a raiz quadrada de 25? }\end{array}$ & $\begin{array}{l}\text { PRA diz: Ou melhor, qual } \\
\text { é o número que elevado ao } \\
\text { quadrado dá } 25 ? \text { E aí, a } \\
\text { gente tem duas } \\
\text { possibilidades } \\
\text { respostas: mais ou menos? }\end{array}$ \\
\hline 8 & $\begin{array}{l}\text { PRA diz: Ou melhor, qual } \\
\text { é o número que elevado ao } \\
\text { quadrado dá } 25 ? \text { E aí, a } \\
\text { gente tem duas } \\
\text { possibilidades de } \\
\text { respostas: mais ou menos? }\end{array}$ & Um aluno responde: 5 . & $\begin{array}{l}\text { PRA: Só que a gente está } \\
\text { falando de triângulos. Já } \\
\text { viram um triângulo } \\
\text { medindo -5 centímetros? } \\
\text { Então, aqui, eu só } \\
\text { considero o } 5 \text { positivo. A }\end{array}$ \\
\hline
\end{tabular}




\begin{tabular}{c|c|cc} 
\# Evento & $\begin{array}{c}\text { Condições propostas por } \\
\text { PRA }\end{array}$ & Ações dos Alunos & $\begin{array}{c}\text { Ocorrências subsequentes } \\
\text { do professor }\end{array}$ \\
\hline & $\begin{array}{l}\text { resposta negativa não } \\
\text { serve. }\end{array}$ \\
\hline
\end{tabular}

Tabela 31 - Tabela Unidades de Análises ou Hipóteses - H19 - PRA - UD - 01

\section{Descrição e análise dos eventos registrados}

Posto a sentença na lousa, PRA pergunta aos alunos qual o tipo de sentença foi representada. Os alunos, de forma complementar e gradual às indagações de PRA, respondem que é uma equação de segundo grau. Em seguida, PRA resolve a equação. Suas indagações exigem respostas complementares dos alunos com relação aos valores correspondentes a cada elemento que formava a equação.

Diante dos registros, é possível observar que PRA adota uma prática que mantém medidas inconclusivas sobre se os alunos emitiriam as respostas solicitadas na ausência da narração efetuada por PRA.

Habilidade: H 24 - Identificar propriedades de triângulos pela comparação de medidas de lados e ângulos.

\begin{tabular}{|c|c|c|c|}
\hline \# Evento & $\begin{array}{c}\text { Condições propostas por } \\
\text { PRA }\end{array}$ & Ações dos Alunos & $\begin{array}{l}\text { Ocorrências subsequentes } \\
\text { do professor }\end{array}$ \\
\hline 1 & $\begin{array}{l}\text { PRA desenha outro } \\
\text { triângulo retângulo na } \\
\text { lousa, com as medidas de } \\
\text { um dos catetos e da } \\
\text { hipotenusa e pergunta: } O \\
\text { que aconteceu? Inverteu ... } \\
\text { X }\end{array}$ & $\begin{array}{l}\text { Um aluno responde: } O X \text {. } \\
O X \text { no lugar do } 20 \text {. }\end{array}$ & $\begin{array}{l}\text { PRA diz: } O 20 \text { eu sei } \\
\text { agora eu quero saber o } \\
\text { que eu não sei. Isso aqui, } \\
\text { nós vamos começar a dar } \\
\text { os nomes para essas } \\
\text { coisas. Num triângulo } \\
\text { retângulo qualquer, nós } \\
\text { vamos batizar os nomes } \\
\text { dos lados do triângulo. Os } \\
\text { dois lados que formam o } \\
\text { angulo de } 90 \text { graus } \\
\text { chamam de? }\end{array}$ \\
\hline 2 & $\begin{array}{l}\text { PRA diz: O } 20 \text { eu sei e } \\
\text { agora eu quero saber o } \\
\text { que eu não sei. Isso aqui, } \\
\text { nós vamos começar a dar } \\
\text { os nomes para essas } \\
\text { coisas. Num triângulo } \\
\text { retângulo qualquer, nós } \\
\text { vamos batizar os nomes } \\
\text { dos lados do triângulo. Os } \\
\text { dois lados que formam o } \\
\text { ângulo de } 90 \text { graus } \\
\text { chamam de? }\end{array}$ & $\begin{array}{l}\text { Alguns alunos respondem: } \\
\text { Catetos. }\end{array}$ & $\begin{array}{l}\text { PRA: Catetos. E esse aqui, } \\
\text { que é o lado maior do } \\
\text { triângulorângulo } \\
\text { [mostrando a hipotenusa } \\
\text { na lousa], esse se chama? }\end{array}$ \\
\hline
\end{tabular}




\begin{tabular}{|c|c|c|c|}
\hline \# Evento & $\begin{array}{c}\text { Condições propostas por } \\
\text { PRA }\end{array}$ & Ações dos Alunos & $\begin{array}{c}\text { Ocorrências subsequentes } \\
\text { do professor }\end{array}$ \\
\hline 3 & $\begin{array}{l}\text { PRA: Catetos. E esse aqui, } \\
\text { que é o lado maior do } \\
\text { triângulorato retângulo } \\
\text { [mostrando a hipotenusa } \\
\text { na lousa], esse se chama? }\end{array}$ & $\begin{array}{l}\text { Alguns alunos respondem: } \\
\text { Hipotenusa. [Os alunos } \\
\text { respondem, depois que } \\
\text { PRA escreveu na lousa a } \\
\text { resposta]. }\end{array}$ & $\begin{array}{l}\text { PRA diz: Hipotenusa. Diz } \\
\text { que a hipotenusa ao } \\
\text { quadrado é igual ao cateto } \\
\text { quadrado mais o outro } \\
\text { cateto ao quadrado. } \\
\text { Então, vamos voltar: quem } \\
\text { é a hipotenusa e quem é o } \\
\text { cateto? }\end{array}$ \\
\hline
\end{tabular}

Tabela 32 - Tabela Unidades de Análises ou Hipóteses - H24 - PRA - UD - 01

\section{Descrição e análise dos eventos registrados}

PRA inicia uma nova atividade, desenhando outro triângulo retângulo na lousa. Ao finalizar o desenho, PRA pergunta a turma o que aconteceu? Os alunos respondem que aparece um X no lugar de 20. Em seguida, PRA orienta oralmente os alunos a reconhecerem os lados do triângulo retângulo posto na lousa. Porém, PRA toma ações reincidentes de um padrão de interação: descreve as dimensões relevantes da situação estimuladora e solicita respostas complementares ou confirmatórias que deixa dúvidas sobre as condições e probabilidades adequadas para os alunos efetuarem as descrições elaboradas por PRA na ausência das condições diante das quais eles se comportaram. Em outras palavras, as ações de PRA não permitem afirmar que as respostas dos alunos seriam observadas na ausência dos questionamentos que ela efetuou.

Habilidade: H19. Resolver problemas que envolvam equações do $2^{\circ}$ grau.

\begin{tabular}{|c|c|c|c|}
\hline \# Evento & $\begin{array}{c}\text { Condições propostas por } \\
\text { PRA }\end{array}$ & Ações dos Alunos & $\begin{array}{l}\text { Ocorrências subsequentes } \\
\text { do professor }\end{array}$ \\
\hline 1 & $\begin{array}{l}\text { PRA diz: Então, vamos } \\
\text { voltar: quem } \quad \text { é } \\
\text { hipotenusa e quem } \\
\text { cateto? }\end{array}$ & $\begin{array}{l}\text { Alguns alunos respondem: } \\
\text { A hipotenusa é } 20 .\end{array}$ & $\begin{array}{l}\text { PRA continua: Então, eu } \\
\text { troco } 20 \text { no lugar do a. } \\
\text { Um cateto é x e o outro é } \\
16 ?\end{array}$ \\
\hline 2 & $\begin{array}{l}\text { PRA continua: Então, eu } \\
\text { troco } 20 \text { no lugar do a. } \\
\text { Um cateto é x e o outro é } \\
16 ?\end{array}$ & $\begin{array}{l}\text { Alguns alunos respondem: } \\
\text { Sim. }\end{array}$ & $\begin{array}{l}\text { PRA diz: Então aqui tanto } \\
\text { faz. O que eu faço agora? } \\
20 \text { ao quadrado }=400 . X \\
\text { ao quadrado continua. } 16 \\
\text { ao quadrado }=256 . \text { O que } \\
\text { eu faço agora? }\end{array}$ \\
\hline 3 & $\begin{array}{l}\text { PRA diz: Então aqui tanto } \\
\text { faz. O que eu faço agora? } \\
20 \text { ao quadrado }=400 . X \\
\text { ao quadrado continua. } 16 \\
\text { ao quadrado }=256 . \text { O que } \\
\text { eu faço agora? }\end{array}$ & $\begin{array}{l}\text { Um aluno responde: } \\
\text { Separa a letra de número. }\end{array}$ & $\begin{array}{l}\text { PRA diz: Separo letra de } \\
\text { número. De que jeito? }\end{array}$ \\
\hline 4 & PRA diz: Separo letra de & continua & PRA: $O$ \\
\hline
\end{tabular}




\begin{tabular}{|c|c|c|c|}
\hline \# Evento & $\begin{array}{c}\text { Condições propostas por } \\
\text { PRA }\end{array}$ & Ações dos Alunos & $\begin{array}{c}\text { Ocorrências subsequentes } \\
\text { do professor }\end{array}$ \\
\hline & número. De que jeito? & $\begin{array}{l}\text { respondendo: } \quad X \quad \text { ao } \\
\text { quadrado é igual ... }\end{array}$ & positivo? \\
\hline 5 & $\begin{array}{l}\text { PRA: } O \text { que estava } \\
\text { positivo? }\end{array}$ & $\begin{array}{l}\text { Alguns alunos respondem: } \\
\text { Negativo. }\end{array}$ & PRA: 256 continua ... \\
\hline 6 & PRA: 256 continua ... & Um aluno responde: - 400. & $\begin{array}{l}\text { PRA: -X quadrado é igual } \\
\text { a }-144 . \quad \text { Como o } X \\
\text { quadrado está negativo, eu } \\
\text { multiplico por -1. X } \\
\text { quadrado é igual a } 144 . \\
\text { Que pergunta eu faço } \\
\text { agora? }\end{array}$ \\
\hline 7 & $\begin{array}{l}\text { PRA: -X quadrado é igual } \\
\text { a -144. Como o } X \\
\text { quadrado está negativo, eu } \\
\text { multiplico por - } 1 . \quad X \\
\text { quadrado é igual a } 144 . \\
\text { Que pergunta eu faço } \\
\text { agora? }\end{array}$ & $\begin{array}{l}\text { Um aluno responde: Que } \\
\text { número elevado é igual a } \\
144 \text { ? }\end{array}$ & $\begin{array}{l}\text { PRA confirma: Que } \\
\text { número elevado é igual a } \\
144 \text { ? Mais } 12 \text { ou menos } \\
12 \text { ? Como é um número de } \\
\text { medida, só o }+12 \text {. }\end{array}$ \\
\hline 8 & $\begin{array}{l}\text { PRA desenha na lousa três } \\
\text { triângulos retângulos. Dois } \\
\text { deles são iguais aos já } \\
\text { vistos pelos alunos, na } \\
\text { aula anterior. O outro é } \\
\text { diferente. E prossegue: } \\
\text { Calcule X em cada caso. } \\
\text { Um cateto é } 4 \text { e o outro é } \\
\text { 3. Quero saber quanto é a } \\
\text { hipotenusa. Então, vou } \\
\text { colocar na Lei de } \\
\text { Pitágoras: } a^{2}=b^{2}+c^{2} \text {. } \\
\text { PRA faz a substituição dos } \\
\text { valores na sentença e } \\
\text { escreve a observação, de } \\
\text { que uma medida nunca é } \\
\text { negativa, dizendo: Aqui, } \\
\text { eu inverti a situação, } \\
\text { tenho a hipotenusa, tenho } \\
\text { um cateto e quero saber o } \\
\text { outro cateto. }\end{array}$ & $\begin{array}{l}\text { Um aluno sai da sala de } \\
\text { aula. }\end{array}$ & $\begin{array}{l}\text { PRA diz: Perdendo a } \\
\text { explicação é complicado. } \\
10 \text { ao quadrado é igual a } 6 \\
\text { ao quadrado mais } x \text { ao } \\
\text { quadrado. } \\
\text { PRA dita a como a } \\
\text { sentença do Teorema de } \\
\text { Pitágoras deve ter suas } \\
\text { variáveis substituídas: } 100 \\
=36+X^{2} . X \text { de um lado, } \\
\text { número do outro. } \\
\text { PRA dita a sentença } \\
\text { novamente: }-X^{2}=36-100 \text {. } \\
\text { Os dois ficaram negativos, } \\
\text { multiplica por }-1 . \\
\text { PRA dita a sentença } \\
\text { novamente: } X^{2}=100-36 . \\
X^{2}=64 . X=+ \text { ou }-8 . \\
\text { Não usamos valor } \\
\text { negativo, pois } \\
\text { trabalhamos com medidas, } \\
\text { apenas } 8 \text { positivo. }\end{array}$ \\
\hline 9 & $\begin{array}{l}\text { PRA dita a sentença } \\
\text { novamente: } X^{2}=100-36 . \\
X^{2}=64 . X=+ \text { ou }-8 . \\
\text { Não usamos valor } \\
\text { negativo, } \quad \text { pois } \\
\text { trabalhamos com medidas, } \\
\text { apenas } 8 \text { positivo. }\end{array}$ & $\begin{array}{l}\text { Um aluno pergunta: Por } \\
\text { que PRA? }\end{array}$ & $\begin{array}{l}\text { PRA responde: Você já viu } \\
\text { uma medida menor que } 0 \text { ? } \\
\text { PRA explica em voz baixa } \\
\text { e continua: } O \text { que } \\
\text { aconteceu aqui? PRA } \\
\text { explica o próximo } \\
\text { problema: } a^{2}=2^{2}+4^{2} \text {, } \\
\text { isso é igual a } a^{2}=4+16 . \\
\text { Então, a hipotenusa é } \\
\text { igual a } X^{2}=20 . \text { Muita } \\
\text { gente vai falar assim: ixi, } \\
\text { não tem raiz. A, gente não } \\
\text { tem raiz? }\end{array}$ \\
\hline 10 & $\begin{array}{l}\text { PRA explica o próximo } \\
\text { problema: } a^{2}=2^{2}+4^{2}, \\
\text { isso é igual a } a^{2}=4+16 . \\
\text { Então, a hipotenusa é } \\
\text { igual a } X^{2}=20 . \text { Muita }\end{array}$ & $\begin{array}{l}\text { Alguns alunos respondem: } \\
\text { Exata. }\end{array}$ & $\begin{array}{l}\text { PRA confirma: Exata. } \\
\text { Existe raiz quadrada de } \\
20 ?\end{array}$ \\
\hline
\end{tabular}




\begin{tabular}{|c|c|c|c|}
\hline \# Evento & $\begin{array}{c}\text { Condições propostas por } \\
\text { PRA } \\
\end{array}$ & Ações dos Alunos & $\begin{array}{l}\text { Ocorrências subsequentes } \\
\text { do professor }\end{array}$ \\
\hline & $\begin{array}{l}\text { gente vai falar assim: ixi, } \\
\text { não tem raiz. A, gente não } \\
\text { tem raiz? }\end{array}$ & & \\
\hline 11 & $\begin{array}{l}\text { PRA confirma: Exata. } \\
\text { Existe raiz quadrada de } \\
20 ?\end{array}$ & Os alunos não respondem. & $\begin{array}{l}\text { PRA continua: Existe. É } \\
\text { um número irracional. } \\
\text { Lembra o número } \\
\text { irracional? A gente não } \\
\text { consegue escrever com } \\
\text { casas depois da vírgula. A } \\
\text { gente deixa indicado. }\end{array}$ \\
\hline 12 & $\begin{array}{l}\text { PRA escreve exercícios na } \\
\text { lousa referente ao } \\
\text { Teorema de Pitágoras e } \\
\text { diz: Semana passada, } \\
\text { vimos que a relação dos } \\
\text { lados de um triângulo } \\
\text { retângulo funciona. Dando } \\
\text { de A o nome da } \\
\text { hipotenusa, que é o lado } \\
\text { maior do retângulo. B e C, } \\
\text { que são os catetos. Essa } \\
\text { medida elevada ao } \\
\text { quadrado é igual a soma } \\
\text { das outras duas medidas } \\
\text { elevadas ao quadrado. E, } \\
\text { agora, vocês tem } 5 \\
\text { situações para que vocês } \\
\text { descubram o valor de X } \\
\text { em cada uma delas. É } \\
\text { para vocês utilizarem essa } \\
\text { relação (Pitágoras) nessas } \\
\text { situações. Então, por } \\
\text { exemplo, a primeira coisa, } \\
\text { é identificar A, que é a } \\
\text { hipotenusa. Quem é A } \\
\text { hipotenusa aqui? }\end{array}$ & $\begin{array}{l}\text { Uma aluna aponta para o } \\
\text { lado que representa a } \\
\text { hipotenusa, em uma das } \\
\text { situações desenhadas por } \\
\text { PRA na lousa, falando que } \\
\text { é o valor } 10 \text {. }\end{array}$ & PRA pergunta: $e B$ e $C$ ? \\
\hline 13 & PRA pergunta: $e B$ e $C$ ? & A aluna responde: 6 e $X$. & $\begin{array}{l}\text { PRA continua: Um é } 6 \text { e } \\
\text { outro é X. Independe, } \\
\text { qualquer um. Aqui } \\
\text { (próximo exercício), que é } \\
\text { a hipotenusa? }\end{array}$ \\
\hline 14 & $\begin{array}{l}\text { PRA continua: Um é } 6 \text { e } \\
\text { outro é X. Independe, } \\
\text { qualquer um. Aqui } \\
\text { (próximo exercício), que é } \\
\text { a hipotenusa? }\end{array}$ & Os alunos falam: $E^{\prime} o X$. & $\begin{array}{l}\text { PRA confirma: É o X. } 12 \text { e } \\
9 \text { são os catetos. Sempre o } \\
\text { mesmo raciocínio. Podem } \\
\text { fazer com os colegas. Eu } \\
\text { vou dar o tempo. São } \\
14: 10 \text {, vou dar até 14:30. } \\
20 \text { minutos dá tempo. }\end{array}$ \\
\hline 15 & $\begin{array}{l}\text { PRA confirma: É o } X .12 \text { e } \\
9 \text { são os catetos. Sempre o } \\
\text { mesmo raciocínio. Podem } \\
\text { fazer com os colegas. Eu } \\
\text { vou dar o tempo. São } \\
\text { 14:10, vou dar até 14:30. } \\
20 \text { minutos dá tempo. }\end{array}$ & $\begin{array}{l}\text { Alguns alunos fazem o } \\
\text { exercício com os colegas, } \\
\text { outros individualmente. }\end{array}$ & $\begin{array}{l}\text { A PRA está sentada em } \\
\text { sua cadeira, fazendo a } \\
\text { chamada. }\end{array}$ \\
\hline 16 & $\begin{array}{l}\text { A PRA está sentada em } \\
\text { sua cadeira, fazendo a } \\
\text { chamada. }\end{array}$ & $\begin{array}{lcc}\text { Uma aluna pergunta } & \text { a } \\
\text { PRA algo } & \text { sobre } & \text { o } \\
\text { exercício, em voz baixa. }\end{array}$ & $\begin{array}{lr}\text { PRA } & \text { responde } \\
\text { afirmativamente } & \text { e } \\
\text { continua sentada em } & \text { sua } \\
\end{array}$ \\
\hline
\end{tabular}




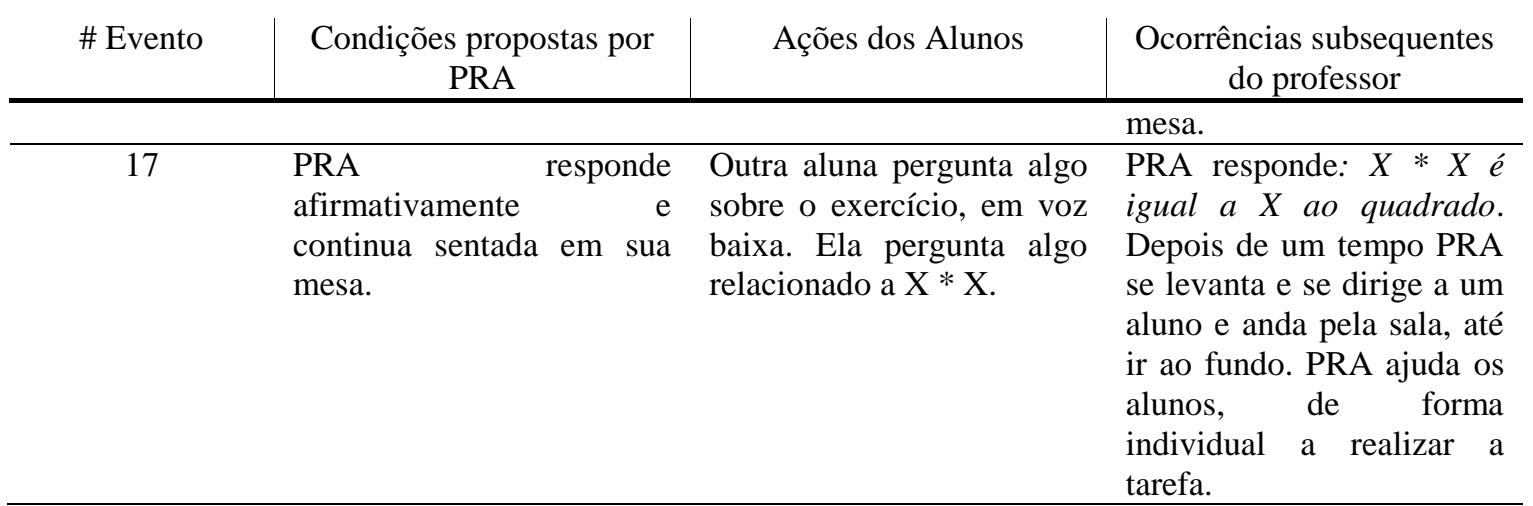

Tabela 33 - Tabela Unidades de Análises ou Hipóteses - H19 - PRA - UD - 01

\section{Descrição e análise dos eventos registrados}

PRA, pela observação dos eventos registrados acima, foca as tarefas dos alunos na construção e resolução de exercícios sobre o Teorema de Pitágoras. Porém, ainda nesta observação foram identificadas ações relacionadas à resolução de uma equação de $2^{\circ}$ Grau, uma vez que PRA prescinde de retomar o Teorema durante a resolução.

As respostas dos alunos gradualmente passam da confirmação de elaboração de PRA para descrição de atividades em função das modificações nas questões elaboradas. Apesar das alterações nos tipos de indagação formuladas por PRA, ainda é possível constatar as descrições de elaboração relacionadas com as respostas desejadas.

Diante deste registro, é inconclusivo o que justificaria PRA manter a descrição oral dos raciocínios, uma vez que, o aluno a partir de tal mudança de contexto, talvez, prosseguiria com os cálculos, prescindindo das narrativas de PRA.

Ao finalizar o primeiro exercício, PRA escreve na lousa mais três exercícios (a partir de \#8) sobre o Teorema de Pitágoras, sendo que no primeiro cálculo o valor encontrado para o cateto é racional. Na sequência, PRA introduz o cálculo de uma hipotenusa, utilizando valores que resultaram um número irracional.

Porém, pelos registros acima, verifica-se que PRA praticamente repete todas as informações prévias da resolução da equação de segundo grau referente ao Teorema de Pitágoras, o que, novamente, torna inconclusivo o desenvolvimento de tal Habilidade pelos alunos, uma vez que PRA: (1) utiliza estratégias que narram e impõem a resolução dos exercícios apresentados; (2) mantém a estratégia de elaboração narrativa, que induz o aluno à resposta.

A partir deste registro de interações, foi observado que a prática de PRA de fornecer a resposta diante do silêncio dos alunos, parece cumprir a função de manter os alunos 
demasiadamente sem responder de modo antecipado nas indagações referentes à resolução dos exercícios.

Ao finalizar os três exercícios, PRA escreve mais cinco na lousa (a partir de \#12) para que os alunos resolvam individualmente. Nos eventos percorridos, foi observado que como padrão de interação proporcionado entre os indivíduos presentes na sala de aula, as respostas dos alunos consiste em identificar dimensões das nomeações elaboradas por PRA.

Diante dos registros, ainda mostra-se inconclusivo se os alunos teriam adquirido habilidades correspondentes com a elaboração das descrições sugeridas por PRA na ausência da "dica" por ela fornecida.

\subsubsection{Etapa 3 - Síntese das análises obtidas na Etapa 2 da UD - 01 de PRA}

Diante da Proposta Curricular do Estado de São Paulo para o Ensino Fundamental - Ciclo II, PRA em sua proposta de atividade, independentemente das condições favorecidas nas interações registradas durante a análise das aulas, abordou alguns dos conteúdos que deveriam permitir aos alunos desenvolverem habilidades e competências previstas na matriz da proposta curricular relacionadas ao Teorema de Pitágoras. Adiante, seguem as análises das interações de PMA promovidas aos alunos.

Pelos registros das interações da UD - 01 de PRA, fica evidente o comportamento de PRA em duas dimensões:

(a) A primeira relacionada às suas práticas de ensino em oferecer restritas condições de participação aos alunos, bem como restritas investigações sobre os pré-requisitos dos alunos, ou seja, prescindiu de ter uma medida do que os alunos "sabem fazer", em que condições "eles fazem o exercício" e que comportamentos podem ser observados que garantiriam que eles aprenderam a fazer um exercício.

(b) A segunda relacionada ao seu planejamento de ensino, que segundo os registros na tabela de Caracterização das Habilidades, privilegia as Competências de Grupo III, que caracterizam as competências para compreender. Porém, diante de suas práticas, essas habilidades acabam por representar competências para realizar, uma vez que as condições de interação mostram que as análises que poderiam se constituir em medida comportamental de compreensão foram realizadas por PRA. 
Diante dos passos percorridos por PRA, coube aos alunos a função de repetir o repertório diante de situações estimuladoras propostas por PRA, que apresentou um modelo (áreas) para compreensão do Teorema. Mas, não deu continuidade a este modelo, estabelecendo assim, relações com os cálculos propostos. Com isso, é inconclusivo, se na ausência de tais estimulações, os alunos realmente conseguiriam identificar ou reconhecer as propriedades do conteúdo curricular previsto.

O contexto elaborado por PRA restringe-se a demonstração de exemplos, exercícios resolvidos na lousa por ela mesma e uma avaliação (prova), que continha os mesmos exercícios resolvidos em sala de aula. Novamente, pela observação realizada pela pesquisadora, significativas parcelas dos desempenhos emitidos pelos alunos foram registradas diante da prática de PRA que não confirmam se os alunos igualmente emitiram tais desempenhos na ausência das práticas.

O efeito da interação de PRA com os alunos, embora as respostas dos mesmos forneçam apenas pistas sobre o que foi aprendido, parecem relacionados com condições de ensino que PRA forneceu: ditar regras, escrever os exercícios na lousa e, depois, resolvê-los para que os alunos copiem. Essas condições de ensino registram como resultado alunos que podem descrever regras, mas que possivelmente não executam procedimentos que lhes permitam resolver os exercícios. Para concluir sobre a questão do desempenho do aluno, seria necessária a identificação de correspondência entre propriedades dos desempenhos dos alunos e características das condições de ensino fornecidas, porém, pela análise, isso não foi constatado.

\subsection{Resultados de PRA - UD - 02}

A Unidade Didática - 02 de PRA tem como tema principal a atividade Aplicação do Teorema de Pitágoras.

\subsubsection{Etapa 1 - Caracterização das habilidades diante das práticas de ensino de PRA}

\begin{tabular}{c|ccccccccccccc}
$\begin{array}{c}\text { Tempo em } \\
\text { minutos }\end{array}$ & \multicolumn{3}{|c}{ Tema 1 } & \multicolumn{4}{c}{ Tema } & \multicolumn{4}{c}{ Tema 3} & \multicolumn{4}{c}{ Tema 4} \\
\hline 01 '50 & GII & GIII & GI & GII & GIII & GI & GII & GIII & GI & GII & GIII \\
\hline
\end{tabular}

Tabela 34 - Tabela de Caracterização das Habilidades - UD 02 - PRA 
Ao assistir a Unidade Didática 02 de PRA, a pesquisadora considerou a H36 como vinculada com as práticas de ensino observadas. A habilidade vinculada está da seguinte forma descrita no SARESP (GOVERNO DO ESTADO DE SÃO PAULO, 2009a):

- H36. Resolver problemas em diferentes contextos, que envolvam as relações métricas dos triângulos retângulos. (Teorema de Pitágoras).

Posta a tabela 34, foram descritas e analisadas as interações registradas considerando cada uma das habilidades vinculadas, levando em consideração a sequência na qual as interações ocorreram. No transcurso da aula, as exposições orais dos alunos e dos professores envolvidos nos episódios de gravação considerados foram destacadas em itálico.

\subsubsection{Etapa 2 - Descrição das habilidades a partir das interações registradas e Análise das interações correspondentes às habilidades vinculadas}

Habilidade: H36. Resolver problemas em diferentes contextos, que envolvam as relações métricas dos triângulos retângulos. (Teorema de Pitágoras).

\begin{tabular}{|c|c|c|c|}
\hline \# Evento & $\begin{array}{c}\text { Condições propostas por } \\
\text { PRA }\end{array}$ & Ações dos Alunos & $\begin{array}{c}\text { Ocorrências subsequentes } \\
\text { do professor }\end{array}$ \\
\hline 1 & $\begin{array}{l}\text { PRA diz: A hipotenusa no } \\
\text { quadro é igual a } B \text { ao } \\
\text { quadrado mais } C \text { ao } \\
\text { quadrado? }\end{array}$ & $\begin{array}{l}\text { Alunos } \text { e } \text { PRA falam } \\
\text { juntos: B ao quadrado } \\
\text { mais } C \text { ao quadrado. } \\
\text { Sim. }\end{array}$ & $\begin{array}{l}\text { PRA diz: A soma do } \\
\text { quadrado dos dois catetos. } \\
\text { Até ontem, dado um } \\
\text { triângulo (e escreve X } \\
\text { para a hipotenusa e os } \\
\text { valores } 4 \text { e } 3 \text { em cada um } \\
\text { dos catetos). Quem vai ser } \\
\text { o valor de X? }\end{array}$ \\
\hline 2 & PRA: Qual é o valor de X? & $\begin{array}{l}\text { Alunos e PRA falam } \\
\text { juntos: } x \text { ao quadrado é } \\
\text { igual a } 4 \text { ao quadrado } \\
\text { mais } 3 \text { ao quadrado. }\end{array}$ & PRA: $16+9 ?$ \\
\hline 3 & PRA: $16+9 ?$ & Alguns alunos: $X=5$ & $\begin{array}{l}\text { PRA: E agora, se eu } \\
\text { falasse para vocês: onde } \\
\text { um cateto mede } 6 \text { e o outro } \\
\text { mede 8. Qual o valor da } \\
\text { hipotenusa? Isso é um } \\
\text { probleminha. Precisa } \\
\text { fazero triângulo? }\end{array}$ \\
\hline 4 & $\begin{array}{l}\text { PRA: E agora, se eu } \\
\text { falasse para vocês: onde } \\
\text { um cateto mede } 6 \text { e o outro } \\
\text { mede 8. Qual o valor da } \\
\text { hipotenusa? Isso é um } \\
\text { probleminha. Precisa } \\
\text { fazero triângulo? }\end{array}$ & $\begin{array}{l}\text { Alguns alunos respondem: } \\
\text { Sim, outros: Não. }\end{array}$ & $\begin{array}{lrr}\text { PRA: } & \text { Precisar, } & \text { não } \\
\text { precisa. } & \text { Mas } & a \\
\text { visualização ajuda. PRA } & \\
\text { desenha o triângulo e, } \\
\text { junto aos alunos, escreve a } \\
\text { sentença e resolve o valor } \\
\text { da hipotenusa. }\end{array}$ \\
\hline 5 & PRA: Tem uma escada de & Um aluno responde: $\dot{E} a$ & PRA diz: É parecido com \\
\hline
\end{tabular}




\begin{tabular}{|c|c|c|c|}
\hline \# Evento & $\begin{array}{c}\text { Condições propostas por } \\
\text { PRA }\end{array}$ & Ações dos Alunos & $\begin{array}{l}\text { Ocorrências subsequentes } \\
\text { do professor }\end{array}$ \\
\hline & $\begin{array}{lll}5 & \text { metros } & d e \\
\text { comprimento/altura, } & \\
\text { encostada } & \text { na parede de } \\
\text { uma casa. O pé da escada } \\
\text { está a } & 2 \text { metros de }\end{array}$ & sombra. & $\begin{array}{l}\text { a sombra. A sombra são os } \\
2 \text { metros. Mas, eu quero } \\
\text { saber a altura da parede } \\
\text { (aponta na lousa qual é a } \\
\text { medida prevista). }\end{array}$ \\
\hline
\end{tabular}

Pergunta: qual é a altura

da parede?

Em seguida, PRA utiliza a sentença do Teorema de Pitágoras e substitui os valores e diz: $5^{2}=2^{2}+x^{2}$. Que é igual a $x$, igual a raiz de 21. A raiz de 21 não é exata. A raiz de 25 é 5. A raiz de 16 é quatro. Por aproximação a raiz de 21 é 4 vírgula alguma coisa.

\begin{tabular}{|c|c|c|c|}
\hline 6 & $\begin{array}{l}\text { Em seguida, PRA utiliza a } \\
\text { sentença do Teorema de } \\
\text { Pitágoras e substitui os } \\
\text { valores e diz: } 5^{2}=2^{2}+x^{2} \text {. } \\
\text { Que é igual a } x \text {, igual a } \\
\text { raiz de } 21 . \text { A raiz de } 21 \\
\text { não é exata. A raiz de } 25 \text { é } \\
5 . \text { A raiz de } 16 \text { é quatro. } \\
\text { Por aproximação a raiz de } \\
21 \text { é } 4 \text {, alguma coisa. }\end{array}$ & Um aluno responde: 4,2 . & $\begin{array}{l}\text { PRA diz: } 4,5 * 4,5= \\
\text { 20,25. Até que é razoável. } \\
\text { Então, a altura da parede } \\
\text { é aproximadamente } 4,5 \text {. } \\
\text { Agora, os exercícios que } \\
\text { vou passar não vão mais } \\
\text { trazer prontinho o } \\
\text { desenho. Vocês vão ter } \\
\text { que ler a história e montar } \\
\text { a visualização. Vocês vão } \\
\text { ter várias situações, } \\
\text { algumas terão o desenho e } \\
\text { outras vocês terão que } \\
\text { desenhar. }\end{array}$ \\
\hline 7 & $\begin{array}{l}\text { PRA: Agora, os exercícios } \\
\text { que vou passar não vai } \\
\text { mais trazer prontinho o } \\
\text { desenho. Vocês vão ter } \\
\text { que ler a história e montar } \\
\text { a visualização. Vocês vão } \\
\text { ter várias situações, } \\
\text { algumas terão o desenho e } \\
\text { outras vocês terão que } \\
\text { desenhar. Em seguida, } \\
\text { solicita aos alunos que } \\
\text { abram o material e dita: } \\
\text { problema 1, problema 2, } \\
\text { problema 3. Para começar, } \\
\text { são esses três problemas. } \\
\text { PRA pede para copiar o } \\
\text { desenho do último } \\
\text { problema no caderno. }\end{array}$ & $\begin{array}{l}\text { Os alunos fazem os } \\
\text { exercícios } \\
\text { individualmente. } \\
\text { Alguns alunos resolvem } \\
\text { juntos os problemas. }\end{array}$ & $\begin{array}{l}\text { PRA anda pela sala e } \\
\text { atende os } \\
\text { individualmente. Depois, } \\
\text { começa a escrever na } \\
\text { lousa. }\end{array}$ \\
\hline 8 & $\begin{array}{l}\text { PRA anda pela sala e } \\
\text { atende os alunos } \\
\text { individualmente. Depois, } \\
\text { começa a escrever na } \\
\text { lousa. }\end{array}$ & $\begin{array}{l}\text { Os alunos copiam o que } \\
\text { PRA está escrevendo na } \\
\text { lousa. }\end{array}$ & $\begin{array}{l}\text { PRA explica que na figura } \\
\text { há dois triângulos } \\
\text { retângulos, um em cima do } \\
\text { outro. Sendo que o X não } \\
\text { é mais a hipotenusa } \\
\text { (explica o problema } 4 \text {, } \\
\text { desenhando na lousa) e } \\
\text { diz: Por enquanto é isso. } \\
\text { Mandem bala nesses }\end{array}$ \\
\hline
\end{tabular}




\begin{tabular}{|c|c|c|c|}
\hline \# Evento & $\begin{array}{c}\text { Condições propostas por } \\
\text { PRA }\end{array}$ & Ações dos Alunos & $\begin{array}{c}\text { Ocorrências subsequentes } \\
\text { do professor }\end{array}$ \\
\hline & & & $\begin{array}{l}\text { exercícios. É bom cada um } \\
\text { tentar fazer sozinho. }\end{array}$ \\
\hline 9 & $\begin{array}{l}\text { PRA explica que na figura } \\
\text { há dois triângulos } \\
\text { retângulos, um em cima do } \\
\text { outro. Sendo que o X não } \\
\text { é mais a hipotenusa } \\
\text { (explica o problema } 4 \text { em } \\
\text { desenho) e diz: Por } \\
\text { enquanto é isso. Mandem } \\
\text { bala nesses exercícios. É } \\
\text { bom cada um tentar fazer } \\
\text { sozinho. }\end{array}$ & $\begin{array}{l}\text { Os alunos voltam a } \\
\text { resolver os exercícios } \\
\text { individualmente. }\end{array}$ & $\begin{array}{l}\text { PRA continua narrando } \\
\text { uma história para os } \\
\text { alunos e, depois, diz: } O \\
\text { enunciado dizia que: Em } \\
\text { um triângulo, os dois } \\
\text { maiores lados medem } 12 \text { e } \\
\text { l3. Então, } \\
\text { obrigatoriamente, } 13 \text { é a } \\
\text { hipotenusa. PRA resolve o } \\
\text { problema. O próximo, diz: } \\
\text { um cateto é } 6, \quad a \\
\text { hipotenusa é 12, quero } \\
\text { saber o outro cateto. PRA } \\
\text { narra a sentença. }\end{array}$ \\
\hline 10 & $\begin{array}{l}\text { PRA continua narrando } \\
\text { uma história para os } \\
\text { alunos e, depois, diz: } O \\
\text { enunciado dizia que: Em } \\
\text { um triângulo, os dois } \\
\text { maiores lados medem } 12 \text { e } \\
\text { l3. Então, } \\
\text { obrigatoriamente, } 13 \text { é a } \\
\text { hipotenusa. PRA resolve o } \\
\text { problema. O próximo, diz: } \\
\text { um cateto é } 6, \quad \text { a } \\
\text { hipotenusa é } 12, \text { quero } \\
\text { saber o outro cateto. PRA } \\
\text { narra a sentença. }\end{array}$ & $\begin{array}{l}\text { Um aluno dita os valores } \\
\text { ao quadrado para PRA. }\end{array}$ & $\begin{array}{l}\text { PRA fatora a raiz quadrada } \\
\text { obtida da última sentença. } \\
\text { PRA resolve o problema } 4 \text {, } \\
\text { pois uma aluna pede. X = } \\
2 \sqrt{2} \mathrm{x}^{2}+(2 \mathrm{x})^{2}=10^{2} . \text { PRA } \\
\text { pede apenas os valores } \\
\text { para os alunos, dizendo } \\
10^{2} \text { é igual a ...? E } \\
\text { responde a questão. } \\
\text { PRA resolve mais um } \\
\text { problema, onde existem x } \\
\text { e y em dois triângulos e } \\
\text { diz: Primeiro triângulo: } x \\
\text { é hipotenusa. }\end{array}$ \\
\hline 11 & $\begin{array}{l}\text { PRA resolve mais um } \\
\text { problema, onde existem } \mathrm{x} \\
\text { e y em dois triângulos } \mathrm{e} \\
\text { diz: Primeiro triângulo: } x \\
\text { é hipotenusa. }\end{array}$ & $\begin{array}{l}\text { Um aluno responde: } x^{2}= \\
4^{2}+3^{2} \text {. Outro diz: Está } \\
\text { errado. }\end{array}$ & $\begin{array}{l}\text { PRA diz: } x^{2}=4^{2}+1^{2} \text {. Esse } \\
\text { é } o X \text {, dá pra achar o } Y \text { ? } \\
Y^{2}=\sqrt{5}+3^{2} . \text { Dúvidas, } \\
\text { pessoal? }\end{array}$ \\
\hline 12 & $\begin{array}{l}\text { PRA diz: } x^{2}=4^{2}+1^{2} \text {.Esse } \\
\text { é o } X \text {, dá pra achar o } Y \text { ? } \\
Y^{2}=\sqrt{5}+3^{2} . \text { Dúvidas, } \\
\text { pessoal? }\end{array}$ & $\begin{array}{l}\text { Alguns alunos respondem: } \\
\text { Não. }\end{array}$ & $\begin{array}{l}\text { PRA continua explicando } \\
\text { o exercício, completando: } \\
\text { Tem que enxergar dois } \\
\text { triângulos aqui. Consegue } \\
\text { enxergar um? Você só } \\
\text { enxerga esse triângulo } \\
\text { aqui. } X^{2}=2^{2}+1^{2} \text {. Então, } x \\
=\sqrt{5} \text {. No lugar de X vou } \\
\text { escrever raiz de } 5 . \text { E como } \\
\text { é que fica esse? Esse é um } \\
\text { quadrado com a diagonal } \\
\text { que chamei de X. Posso } \\
\text { olhar dessa parte de baixo } \\
\text { aqui do triângulo? Cateto } \\
\text { 4, cateto 4, hipotenusa X. }\end{array}$ \\
\hline 13 & $\begin{array}{l}\text { PRA continua explicando } \\
\text { o exercício, completando: } \\
\text { Tem que enxergar dois } \\
\text { triângulos aqui. Consegue } \\
\text { enxergar um? Você só } \\
\text { enxerga esse triângulo }\end{array}$ & $\begin{array}{l}\text { Alunos concordam com } \\
\text { uma avaliação no dia } \\
\text { seguinte. }\end{array}$ & $\begin{array}{l}\text { PRA escreve na lousa mais } \\
\text { dois exercícios e pede para } \\
\text { os alunos resolverem (eles } \\
\text { devem } \\
\text { individualmente). }\end{array}$ \\
\hline
\end{tabular}




\begin{tabular}{|c|c|c|c|}
\hline \# Evento & $\begin{array}{c}\text { Condições propostas por } \\
\text { PRA }\end{array}$ & Ações dos Alunos & $\begin{array}{c}\text { Ocorrências subsequentes } \\
\text { do professor }\end{array}$ \\
\hline & $\begin{array}{l}\text { aqui. } X^{2}=2^{2}+1^{2} \text {. Então, } x \\
=\sqrt{5} \text {. No lugar de } X \text { vou } \\
\text { escrever raiz de } 5 . \text { E como } \\
\text { é que fica esse? Esse é um } \\
\text { quadrado com a diagonal } \\
\text { que chamei de X. Posso } \\
\text { olhar dessa parte de baixo } \\
\text { aqui do triângulo? Cateto } \\
4, \text { cateto } 4 \text {, hipotenusa X. } \\
\text { PRA avisa os alunos que } \\
\text { haverá avaliação no dia } \\
\text { seguinte. }\end{array}$ & & $\begin{array}{l}\text { Depois de um tempo, PRA } \\
\text { pergunta: Aluno } X, \text { fez } \\
\text { todos? }\end{array}$ \\
\hline 14 & $\begin{array}{l}\text { PRA escreve na lousa mais } \\
\text { dois exercícios e pede para } \\
\text { os alunos resolverem (eles } \\
\text { devem fazer } \\
\text { individualmente). }\end{array}$ & $\mathrm{O}$ aluno responde: $F i z$. & $\begin{array}{l}\text { PRA diz: Então como é } \\
\text { que começa o primeiro? }\end{array}$ \\
\hline & $\begin{array}{l}\text { Depois de um tempo, PRA } \\
\text { pergunta: Aluno } X, \text { fez } \\
\text { todos? }\end{array}$ & & \\
\hline 15 & $\begin{array}{l}\text { PRA diz: Então como é } \\
\text { que começa o primeiro? }\end{array}$ & O aluno responde: $X^{2}=$ & $\begin{array}{l}\text { PRA diz: } O \text { primeiro } \\
\text { exercício dá } x=9 . \text { E esse? } \\
\text { [PRA dita todas as } \\
\text { equações dos exercícios.] }\end{array}$ \\
\hline 16 & $\begin{array}{l}\text { PRA diz: } O \text { primeiro } \\
\text { exercício dá } x=9 . \text { E esse? } \\
\text { [PRA dita todas as } \\
\text { equações dos exercícios.] }\end{array}$ & $\begin{array}{l}\mathrm{O} \text { aluno responde: } X^{2}+1^{2} \\
=\text { raiz quadrada de } 17\end{array}$ & $\begin{array}{l}\text { PRA diz: } X^{2}+1=17, \\
\text { então, } x=\text { raiz de } 16 . X= \\
\text { 4. Próximo exercício: os } \\
\text { lados do triângulo medem } \\
7,25,24 . \text { Para que o } \\
\text { triângulo seja retângulo } \\
\text { tem que ser de acordo com } \\
\text { o Teorema de Pitágoras. } \\
25 \text { é hipotenusa, } 24 \text { e } 7 \\
\text { são os catetos. Como eu } \\
\text { sei que } 25 \text { é a hipotenusa? }\end{array}$ \\
\hline 17 & $\begin{array}{l}\text { PRA diz: } X^{2}+1=17, \\
\text { então, } x=\text { raiz de } 16 . X= \\
\text { 4. Próximo exercício: os } \\
\text { lados do triângulo medem } \\
7,25,24 . \text { Para que o } \\
\text { triângulo seja retângulo } \\
\text { tem que ser de acordo com } \\
o \text { Teorema de Pitágoras. } \\
25 \text { é hipotenusa, } 24 \text { e } 7 \\
\text { são os catetos. Como eu } \\
\text { sei que } 25 \text { é a hipotenusa? }\end{array}$ & O aluno responde: Maior. & $\begin{array}{l}\text { PRA diz: É o maior. Para } \\
\text { funcionar, tem que } \\
\text { funcionar o teorema. } 25^{2}= \\
24^{2}+7^{2} \text {. É um triângulo } \\
\text { retângulo, pois existe } \\
\text { igualdade. }\end{array}$ \\
\hline 18 & $\begin{array}{l}\text { É o próximo dia, quando } \\
\text { haverá a avaliação. PRA } \\
\text { conta até } 3 \text { para a classe } \\
\text { ficar em silêncio e escreve } \\
\text { na lousa as questões da } \\
\text { avaliação. }\end{array}$ & $\begin{array}{l}\text { Os alunos copiam em } \\
\text { silêncio. }\end{array}$ & $\begin{array}{l}\text { PRA diz: Sobre o primeiro } \\
\text { exercício, não tem nem o } \\
\text { que falar. São } 4 \text { triângulos } \\
\text { retângulos, em alguns } \\
\text { faltam a hipotenusa e } \\
\text { outros o cateto. } \\
\text { Aqui, é um triângulo } \\
\text { retângulo, mas tem algo } \\
\text { especial. Aqui, tem uma } \\
\text { figura parecida com a } \\
\text { daquele dia, formada por }\end{array}$ \\
\hline
\end{tabular}




\begin{tabular}{|c|c|c|c|}
\hline \# Evento & $\begin{array}{c}\text { Condições propostas por } \\
\text { PRA }\end{array}$ & Ações dos Alunos & $\begin{array}{c}\text { Ocorrências subsequentes } \\
\text { do professor }\end{array}$ \\
\hline & & & $\begin{array}{l}\text { um retângulo e um } \\
\text { triângulo. } \\
\text { Três: num retângulo, a } \\
\text { hipotenusa mede } 15 \text { e o } \\
\text { cateto mede 12, quanto } \\
\text { mede o outro cateto? } \\
\text { Então, faz o desenhinho e } \\
\text { coloca as coisas no lugar } \\
\text { certo. } \\
\text { O quarto: Uma escada tem } \\
5 \text { metros de comprimento e } \\
\text { está apoiada no topo do } \\
\text { muro. O pé da escada está } \\
\text { a } 3 \text { metros de distância da } \\
\text { base do muro. Qual é a } \\
\text { altura do muro? Podem } \\
\text { olhar no caderno. }\end{array}$ \\
\hline 19 & $\begin{array}{l}\text { PRA diz: Essas são as } \\
\text { questões, valem 5. Podem } \\
\text { olhar no caderno. }\end{array}$ & $\begin{array}{l}\text { Os alunos fazem } \\
\text { exercícios. }\end{array}$ & - \\
\hline
\end{tabular}

Tabela 35 - Tabela Unidades de Análises ou Hipóteses - H36 - PRA - UD - 02

\section{Descrição e análise dos eventos registrados}

PRA inicia a aula retomando o Teorema de Pitágoras com os alunos, desenhando um triângulo retângulo na lousa e solicitando que os alunos calculem o valor de $X$, que no dado triângulo, representa a hipotenusa. Nesta sequência de cálculos, os alunos seguem a elaboração de PRA, respondendo diretamente os valores previstos como resposta.

Em seguida, PRA modifica o contexto e, oralmente, expõe um novo exercício, sem, contudo, desenhar o triângulo retângulo na lousa. Sua próxima questão recai sobre a necessidade ou não de realizar o desenho do triângulo. Alguns alunos respondem que sim, outros que não e PRA complementa dizendo que a visualização ajuda a resolver o problema. Neste momento, PRA desenha o triângulo retângulo na lousa e resolve o exercício, desenvolvendo o mesmo tipo de interação: os alunos complementam suas elaborações.

No próximo exercício, PRA utiliza como contexto uma escada encostada na parede de uma casa e solicita aos alunos que encontrem a altura desta parede. De mesmo modo, os alunos participam da resolução do exercício complementando as elaborações de PRA. Ao finalizar essa sequência, PRA inicia uma nova atividade, que contém 5 exercícios, que foram resolvidos individualmente. No momento da correção, PRA elaborou os exercícios na lousa, oralizando as decisões que deveriam ser tomadas nas resoluções e solicitando aos 
alunos que respondessem questões diretas, como por exemplo, "Como eu sei que 25 é a hipotenusa?".

A avaliação realizada na aula subsequente era composta por 4 exercícios, que correspondiam aos exercícios realizados anteriormente em sala de aula.

\subsubsection{Etapa 3 - Síntese das análises obtidas na Etapa 2 da UD - 02 de PRA}

As interações registradas nas aulas da UD2 de PRA evidenciaram, de modo reincidente, a independência de suas ações em relação à obtenção de medidas sobre os desempenhos dos alunos. Assim, nos eventos nos quais ocorreram respostas divergentes dos alunos para questionamentos expostos por PRA, ela prosseguiu nas explicações orais com demonstrações sem explorar possíveis fatores relacionados com a determinação das respostas divergentes.

Além disso, em praticamente todas as descrições e comentários sobre os exercícios propostos, bem como sobre as respectivas resoluções, as ações de PRA prescindiram de avaliações prévias sobre possíveis efeitos das interações anteriores sobre os desempenhos previstos.

Em outros termos, PRA descreveu, comentou, demonstrou e, muitas vezes, solucionou os exercícios, independentemente da emissão de respostas pelos alunos que poderiam indicar a necessidade de tais ações ou mesmo de ações distintas daquelas emitidas por PRA.

Deste modo, a reincidência de tal independência entre as ações de PRA e as medidas de desempenho dos alunos salienta, na realidade, que as interações registradas nas aulas da UD - 02 praticamente ignoram procedimentos por meio dos quais PRA poderia obter medidas dos possíveis efeitos de suas ações sobre os repertórios previstos para os respectivos conteúdos curriculares. 


\section{RESULTADOS: ELABORAÇÃO DE PROPOSTAS PARA RECURSOS DIDÁTICOS INFORMATIZADOS}

"Há trabalho mais importante a ser feito, no qual as relações da professora com o aluno não podem ser duplicadas por um aparelho mecânico. Os recursos instrumentais só virão melhorar estas relações insubstituíveis." (SKINNER, 1968; p.25)

Para Skinner (1968, p. 98), a criança narra um vídeo que assistiu ou um livro leu com detalhes. Isso pode nos fornecer pistas sobre seu comportamento, que nos parece natural: "um amor ao saber" ou "sede inerente de aprender". Para ele, ainda, é necessário aproveitar esse "dote natural" para inserir o aluno em contextos sobre os quais deve realmente aprender.

Porém, existem dificuldades práticas, quando nos referimos a "contextos", pois apenas uma parte do que é o mundo real (Skinner, 1968, p. 98), mesmo contando com recursos, que naquela época limitavam-se a fitas de cinema, televisão e, atualmente, os computadores e a Internet, pode ser realmente trazido para dentro da sala de aula. Críticas daquela época, ainda hoje, parecem ser realidade na sala de aula: a prática excessivamente verbal da educação clássica mostra que o aluno não aprende simplesmente dizendo a ele o que fazer. É necessário, segundo Skinner $(1968,99)$, o "reforço positivo". O aluno, em uma aula planejada com o apoio de recursos como a lousa, o livro didático e nas interações verbais com o professor, ouve, olha, mas nem sempre as contingências que levaria ao surgimento do comportamento almejado pelo professor são programadas e reprogramadas (elaboradas ou reelaboradas) ao longo de uma aula. Porém, o professor

por não ter sido ensinado a olhar para condições ambientais que produzem alunos desinteressados, que se esquivam e fogem da escola, o professor não identifica suas próprias ações como parte importante da explicação dos comportamentos dos alunos. Perde assim, a chance de alterar essas condições e de ver alterações acontecerem em seus alunos. (SPARVOLI, 2008; p. 144-145)

Nesta seção, serão apresentadas as propostas elaboradas para os recursos didáticos informatizados, levando em consideração as análises realizadas na seção anterior deste trabalho, com a intenção de propor uma programação que forneça as condições consideradas importantes nas interações dos alunos com o professor e o material didático, diante da fundamentação teórica que norteia o desenvolvimento deste trabalho.

Portanto, serão apresentadas duas propostas para recursos didáticos informatizados, sendo uma para PMA e outra para PRA. 


\subsection{Recurso didático informatizado para PMA}

PMA, nas duas Unidades Didáticas (UD) analisadas neste trabalho, ministrou conteúdos referentes a temas complementares, sendo a UD - 01 planejada sob o tema Leitura e Construção de Tabelas e a UD - 02 sob o tema Leitura e Construção de Gráficos.

Para o delineamento da proposta para recurso didático informatizado, devido à proximidade dos temas ministrados e também às características da prática de ensino de PMA identificadas a partir das análises, a pesquisadora decidiu em elaborar um recurso, que será apresentado nos próximos tópicos.

A pesquisadora considerou que os materiais didáticos elencados e utilizados por PMA em suas aulas ministradas estão de acordo com as habilidades e competências sugeridas no SARESP. Sendo assim, foi eleita a atividade apresentada na UD-01, que utilizou como material didático a tabela a seguir:

\begin{tabular}{|c|c|c|c|c|c|}
\multirow{2}{*}{ Idade } & \multicolumn{2}{|c|}{ Meninos } & \multirow{2}{*}{ Idade } & \multicolumn{2}{c|}{ Meninas } \\
\cline { 2 - 3 } \cline { 5 - 5 } & Peso (Kg) & Estatura (cm) & & Peso (Kg) & Estatura (cm) \\
\hline 6 & 21 & 116 & 6 & 19 & 115 \\
\hline 7 & 22 & 122 & 7 & 22 & 120 \\
\hline 8 & 25 & 127 & 8 & 25 & 126 \\
\hline 9 & 28 & 132 & 9 & 28 & 132 \\
\hline 10 & 31 & 137 & 10 & 33 & 138 \\
\hline 11 & 35 & 143 & 11 & 37 & 145 \\
\hline 12 & 40 & 150 & 12 & 41 & 151 \\
\hline 13 & 45 & 156 & 13 & 45 & 157 \\
\hline 14 & 51 & 163 & 14 & 50 & 160 \\
\hline
\end{tabular}

Tabela 36 - Modelo das Tabelas de Estatura e Peso de Meninas e Meninos - PMA - UD - 01

\subsubsection{Etapa 4.1 - Descrever a programação do ensino das UDs}

De acordo com as análises realizadas, a programação do ensino planejada por PMA em sua Unidade Didática (UD) - 01 apresenta o seguinte plano, identificado nos registros em vídeo:

\begin{tabular}{|c|c|c|}
\hline Ações de PMA - UD01 & $\begin{array}{c}\text { Descrição das Habilidades - } \\
\text { SARESP }\end{array}$ & $\begin{array}{l}\text { Interações favorecidas e } \\
\text { Recursos providos }\end{array}$ \\
\hline $\begin{array}{l}\text { 1. Tema e atividade da aula } \\
\text { escritos na lousa: construção } \\
\text { de tabelas; } \\
\text { 2. Exposição oral sobre duas }\end{array}$ & $\begin{array}{l}\text { - } \quad \text { De \#1 a \#3, PMA expõe a } \\
\text { atividade a ser realizada. } \\
\text { - } \quad \text { Em \#4, PMA inicia a atividade, } \\
\text { abordando a habilidade H22 (GI). }\end{array}$ & $\begin{array}{l}\text { Todas as interações foram } \\
\text { realizadas entre professor e } \\
\text { aluno, sendo que a atividade } \\
\text { era individual. }\end{array}$ \\
\hline
\end{tabular}




\begin{tabular}{|c|c|c|c|}
\hline 4. & $\begin{array}{l}\text { tabelas contendo medidas de } \\
\text { peso e estatura considerados } \\
\text { com padrão por idades, } \\
\text { sendo uma para meninos e } \\
\text { outra para meninas; } \\
\text { Distribuição de cópias das } \\
\text { tabelas para os alunos lerem; } \\
\text { Exposição oral e escrita, na } \\
\text { lousa, de exemplos de } \\
\text { conversão de unidades de } \\
\text { medida; } \\
\text { Proposição de uma só tabela } \\
\text { que comparassem as medidas } \\
\text { por sexo, questionamentos } \\
\text { dirigidos aos alunos sobre a } \\
\text { melhor forma para construir } \\
\text { a nova tabela; } \\
\text { Construção na lousa, pela } \\
\text { professora, da tabela } \\
\text { proposta com os dados das } \\
\text { tabelas distribuídas }\end{array}$ & $\begin{array}{l}\text { Em \#5, PMA percorre uma } \\
\text { sequência que se inicia com ações } \\
\text { que fornecem condições para o } \\
\text { desenvolvimento da habilidade } \\
\text { H29 (GIII), voltando para H22 } \\
\text { (GI), depois para H23(GII) e, em } \\
\text { seguida, H10 (GII). Neste } \\
\text { percurso, PMA inicia a proposição } \\
\text { da elaboração da nova tabela } \\
\text { (H29), porém, volta para o } \\
\text { reconhecimento e estimativa de } \\
\text { medidas de unidade, relacionadas } \\
\text { na tabela, principalmente, sobre a } \\
\text { estatura (cm), chegando a realizar } \\
\text { cálculos de adição para que os } \\
\text { alunos compreendessem a } \\
\text { conversão de medidas, neste caso, } \\
\text { de cm para m. } \\
\text { Em \#6, PMA volta a criar } \\
\text { condições que favorecem o } \\
\text { desenvolvimento da H29 (GIII). }\end{array}$ & $\begin{array}{l}\text { - O aluno deveria utilizar as } \\
\text { tabelas entregues e, quando } \\
\text { recortá-las, colá-las no } \\
\text { caderno. } \\
\text { - } \quad \text { PMA utiliza exposição oral } \\
\text { e escrita na lousa para } \\
\text { explicar e resolver a } \\
\text { atividade. }\end{array}$ \\
\hline
\end{tabular}

Quadro 1 - Programação do Ensino - PMA - UD-01

Já para a Unidade Didática (UD) - 02 de PMA foi observada a seguinte programação do ensino:

\begin{tabular}{|c|c|c|}
\hline Ações de PMA - UD02 & $\begin{array}{c}\text { Descrição das Habilidades - } \\
\text { SARESP }\end{array}$ & $\begin{array}{l}\text { Interações favorecidas e } \\
\text { Recursos providos }\end{array}$ \\
\hline $\begin{array}{l}\text { 1. Tema e atividade da aula } \\
\text { escritos na lousa: Leitura de } \\
\text { Gráficos; } \\
\text { 2. Distribuição de um recorte } \\
\text { de jornal que traz um mapa } \\
\text { meteorológico do estado de } \\
\text { São Paulo para cada aluno; } \\
\text { 2. Localização das cidades de } \\
\text { São Paulo e Bauru; } \\
\text { 4. Exposição oral das legendas } \\
\text { do mapa; }\end{array}$ & 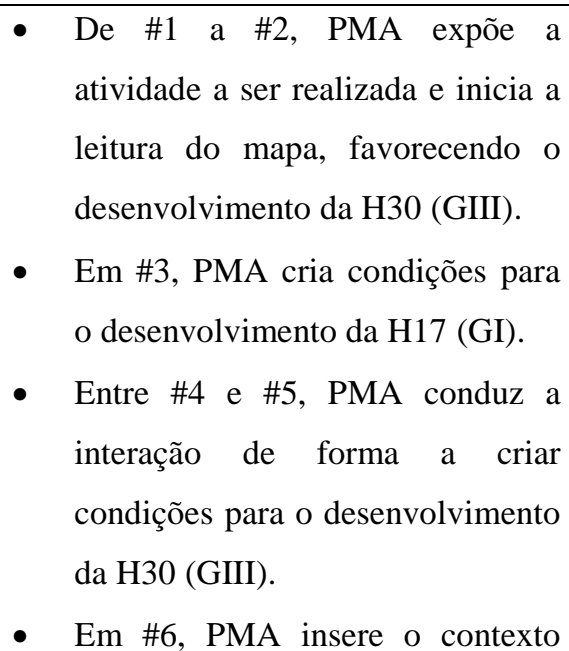 & 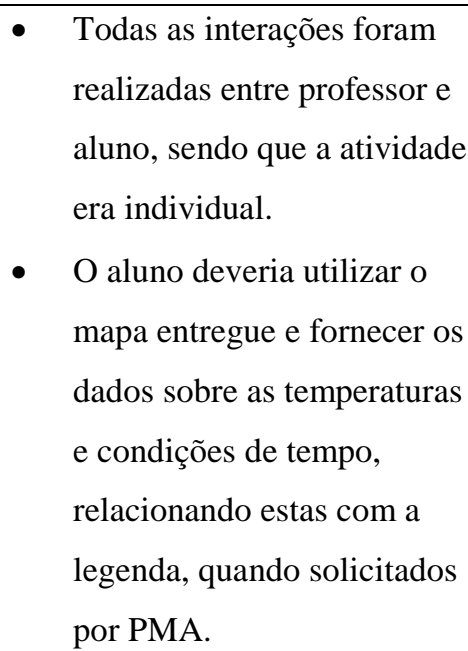 \\
\hline
\end{tabular}




\begin{tabular}{|c|c|c|}
\hline $\begin{array}{l}\text { 5. Identificação dos elementos } \\
\text { que compõem o quadro de } \\
\text { previsão de temperatura de } \\
\text { Bauru; } \\
\text { 6. Explicação sobre o que são } \\
\text { as temperaturas máximas e } \\
\text { mínimas; } \\
\text { 7. dentificação } \\
\text { temperaturas em Graus } \\
\text { Celsius; } \\
\text { Construção de quadros para } \\
\text { reunir os dados de cada } \\
\text { recorte entre as datas } 01 / 04 \text { a } \\
\text { 07/04. } \\
\text { Construção de uma tabela } \\
\text { com dados sobre temperatura } \\
\text { mínima e máxima, utilizando } \\
\text { os dados agrupados nos } \\
\text { quadros já construídos. } \\
\text { os dados das temperaturas } \\
\text { máximas por data. }\end{array}$ & $\begin{array}{l}\text { para o desenvolvimento de outra } \\
\text { habilidade: H22 (GI), quando } \\
\text { explica as temperaturas. } \\
\text { - De \#7 a \#10, PMA tem ações que } \\
\text { poderiam favorecer } \\
\text { desenvolvimento das habilidades } \\
\text { do Grupo III - Competências para } \\
\text { compreender, retomando a H30 } \\
\text { (GIII) e incluindo no processo a } \\
\text { H29 (GIII). }\end{array}$ & $\begin{array}{l}\text { - PMA utiliza exposição oral } \\
\text { e escrita na lousa para } \\
\text { explicar e resolver a } \\
\text { atividade. }\end{array}$ \\
\hline
\end{tabular}

Quadro 2 - Programação do Ensino - PMA - UD-02

\subsubsection{Etapa 4.2 - Elencar as principais características das Práticas de Ensino analisadas}

De acordo com as análises das Unidades Didáticas de PMA, embora ambas tenham temas diferentes, porém, complementares, foi possível observar características reincidentes nas práticas de ensino e avaliação registradas, sendo que algumas delas também foram observadas por SPARVOLI (2008):

1. Fornecimento de respostas corretas;

2. Independência de suas ações em relação à obtenção de medidas sobre os desempenhos dos alunos;

3. Utilização de estratégias orais em questionamentos muito gerais; 
4. Criação de condições favoráveis para a manifestação de repertórios de comportamentos para a cópia;

5. Medidas de desempenho relacionadas aos resultados sem a preocupação com as fontes de controle de estímulo;

6. Insistência em determinados questionamentos que ignoraram a ausência de repertórios dos alunos para responder as questões;

7. Ausência de vocabulário inteligível.

As características da prática de ensino de PMA acima colocadas forneceram dados para o planejamento dos recursos, de modo que, estes recursos, ainda que dependam da ação do professor para sua aplicação e avaliação, possam oferecer condições que ampliam as possibilidades de emissão de repertórios consistentes com as habilidades priorizadas.

\subsubsection{Etapa 4.3 - Delinear o recurso didático informatizado}

Devido às reincidências das características de desempenho de PMA em interações com os alunos e em termos da utilização dos materiais disponíveis, bem com dos conteúdos abordados em suas aulas, a pesquisadora escolheu sistematizar apenas um recurso didático informatizado.

Abaixo, está posta a tabela com os dados sobre o recurso didático. Alguns desses dados são provenientes das análises realizadas das aulas registradas em vídeo, outros dados são frutos da pesquisa deste trabalho.

Dados do Recurso didático informatizado

\begin{tabular}{ll}
\hline Série/Ano: & Ensino Fundamental - Ciclo I $4^{\mathrm{a}} / 5^{\circ}$ \\
\hline Disciplina: & Matemática \\
\hline Título: & A tabela do Médico! \\
\hline Tema principal: & Tratamento da Informação. \\
\hline Conteúdos ou conceitos envolvidos: & Leitura e Construção de Tabelas \\
\hline Habilidades envolvidas: & Habilidades do Grupo III - Competências para \\
& Compreender: \\
& $\bullet \quad$ H29. Ler e/ou interpretar informações e dados \\
& $\quad$ apresentados em tabelas e construir tabelas. \\
\hline Objetivos do Recurso & $\bullet \quad$ Interpretar informações e dados representados em tabela. \\
\hline Conhecimentos prévios & Habilidades do Grupo I - Competências para Observar: \\
\hline
\end{tabular}


- H22. Reconhecer unidades de medida usuais de comprimento, de superfície, de capacidade, de tempo e de temperatura.

Habilidades do Grupo II - Competências para Realizar:

- H23. Estimar a medida de grandezas utilizando unidades de medida convencionais ou não.

Habilidades do Grupo III - Competências para

Compreender:

- H26. Resolver problemas significativos utilizando unidades de medida padronizadas como $\mathrm{km} / \mathrm{m} / \mathrm{cm} / \mathrm{mm}$, $\mathrm{kg} / \mathrm{g} / \mathrm{mg}, 1 / \mathrm{ml}$.

\section{Habilidade não registrada:}

- $\quad$ Reconhecer/identificar uma tabela.

\begin{tabular}{ll}
\hline Tempo previsto: & 50 minutos. \\
\hline Tecnologias utilizadas: & Este recurso será desenvolvido, utilizando a ferramenta Adobe \\
& Macromedia Flash, que exige a instalação de um plug-in, \\
& disponível na Internet, no endereço: \\
\hline Resumo do Recurso: & O aluno irá interagir com uma tela de apresentação e uma \\
& tela inicial contendo textos e ilustrações (duas \\
& personagens) que descrevem a atividade a ser realizada. \\
& Na primeira tela, o aluno poderá escolher a personagem \\
& que “conduzirá” a atividade para com ele. Já a segunda \\
& tela, introduzirá a atividade. \\
& Nas telas seguintes serão apresentadas algumas situações \\
& para que o aluno as responda, analisando a tabela \\
& mostrada na atividade. A cada novo conjunto de \\
& informação apresentada uma resposta será requisitada do \\
aluno. Sempre que a resposta não for correta, ela não será & fixada e o aluno terá que fazer outra tentativa.
\end{tabular}

Tabela 37 - Recurso didático informatizado - PMA

De acordo com as análises realizadas, entendemos que PMA, em suas aulas ministradas, tinha como objetivo o desenvolvimento/a aquisição das habilidades e competências associadas ao Tema 4: Tratamento da Informação.

Desta forma, elegemos algumas das habilidades, descritas para o Tema 3: Grandezas e medidas, como habilidades que já foram adquiridas, ou seja, de Conhecimentos prévios, pois o assunto tratado na atividade remete o aluno às habilidades relacionadas ao tema 3. Sendo assim, como Conhecimentos Prévios, inserimos na Tabela 37, as habilidades 
que os alunos deverão apresentar ao longo do desenvolvimento da atividade proposta. Essas habilidades, ainda, estão relacionadas aos três grupos de competência: Observar, Realizar e Compreender.

Com isso, o plano de ensino que norteou o planejamento do recurso toma como ponto de partida que os alunos tem condições de emitir os repertórios consistentes com as habilidades relacionadas ao Tema 3, fazemos apenas uma recapitulação ou resumo sobre estes conteúdos, como forma de feedback, caso sejam verificadas respostas incorretas em determinadas situações propostas.

Este tipo de planejamento também poderá fornecer informações a PMA que a façam retomar, em sala de aula, os conteúdos previstos para o Tema 3, em novas elaborações e programações das contingências.

\section{O planejamento do recurso didático informatizado}

É importante observar que as telas apresentadas no recurso elaborado foram redigidas com terminologias em níveis crescentes de complexidade. Assim, a linguagem e os termos utilizados deveriam proporcionar condições para que o aluno emitisse os comportamentos desejados sem necessitar de acesso a outras fontes de informação. Cabe ressaltar que as telas específicas disponibilizaram "links" para acesso à informações estimadas relevantes para garantir a emissão dos comportamentos previstos. Como em uma montagem de apresentação em PowerPoint, são inseridas imagens e textos. Por se tratar de um trabalho voltado para o Ensino Fundamental - Ciclo I é interessante que o conteúdo seja apresentado com cores e movimentos, bem como em uma elaboração de texto adequada ao aluno de $4^{\mathrm{a}}$ série $/ 5^{\circ}$ ano.

A primeira tela do recurso apresenta duas personagens com as quais o aluno poderá interagir. Sendo assim, o recurso permite que ele escolha, clicando sobre a imagem da personagem, com qual delas ele deseja realizar a atividade. 


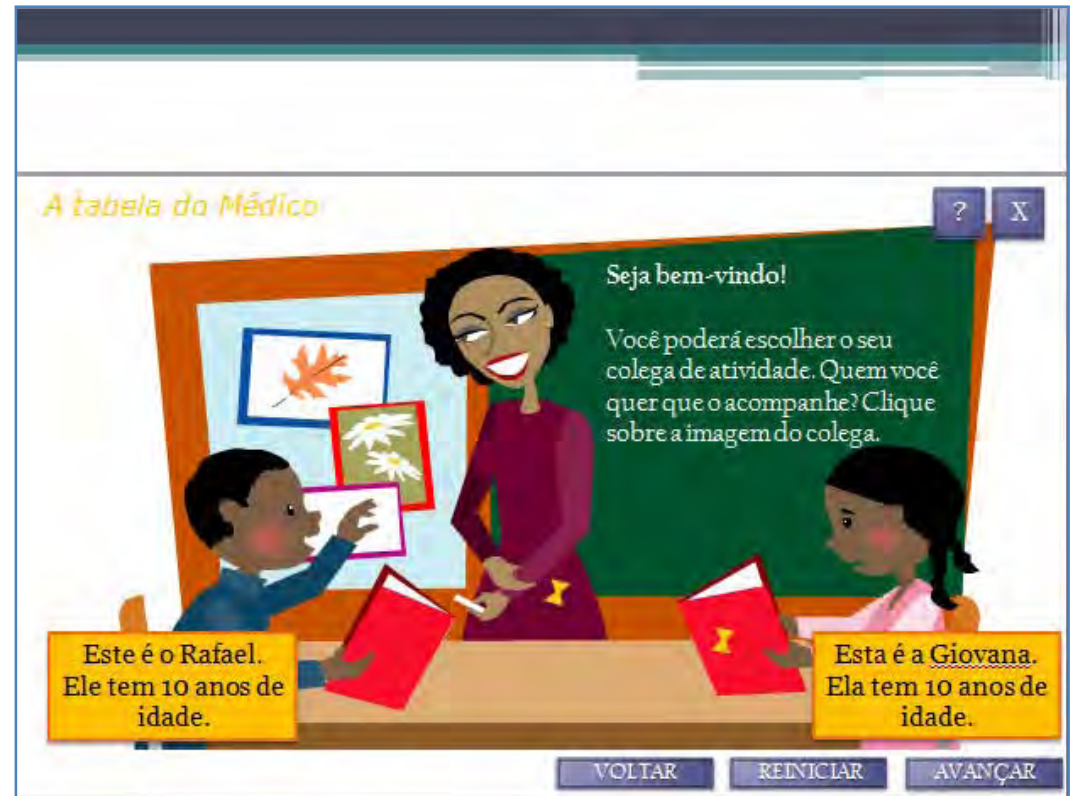

Figura 9 - Tela 1 - Recurso didático informatizado - PMA

Para exemplificar o uso do recurso e como ele foi delineado, foi utilizada a personagem Rafael. Com isso, o recurso apresentará as atividades com questões relacionadas às colunas dos dados dos meninos. Caso o aluno escolha a personagem Giovana, o recurso inverteria a ordem de apresentação das colunas para que o aluno interaja, inicialmente, com os dados referentes às colunas das meninas.

Ao clicar sobre a imagem do colega de atividade, a próxima tela será exibida e a personagem "pergunta" qual o nome do aluno. A caixa azul exemplifica o espaço para que o aluno digite seu nome. 


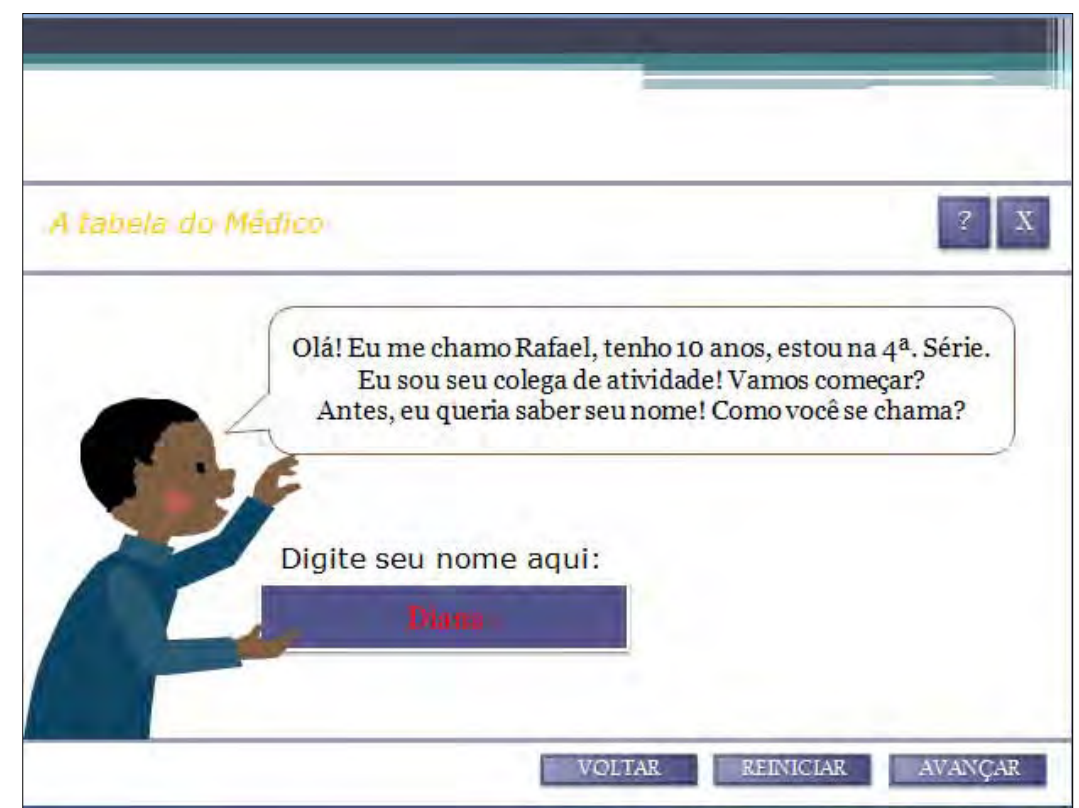

Figura 10 - Tela 2 - Recurso didático informatizado - PMA

A personagem sempre chamará o aluno que realiza a interação com o recurso pelo nome. Para exemplificar, foi inserido o nome Diana, que ficará em vermelho para indicar que é apenas um exemplo. Assim que o aluno digitar seu nome, ele deverá clicar em Avançar.

$\mathrm{Na}$ tela seguinte, a personagem iniciar a proposição de uma atividade para leitura: Diana, eu tive uma aula de Educação Física e, minha professora me falou que preciso praticar mais esportes. Só que eu não sei muito bem o por quê! Você poderia me ajudar? Preciso estudar a tabela na lousa: O aluno poderá manter-se nesta tela o tempo necessário para ler a tabela apresentada. Quando ele considerar que leu a tabela, poderá clicar no botão Avançar. 


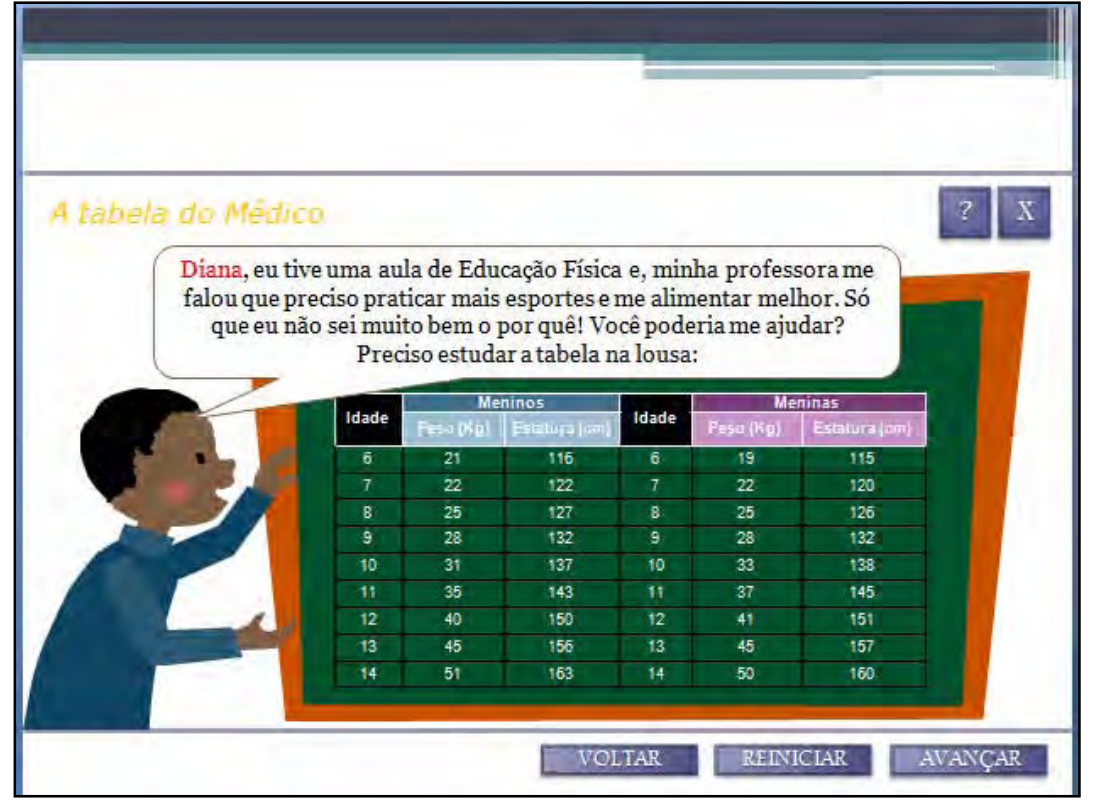

Figura 11 - Tela 3 - Recurso didático informatizado - PMA

Na tela seguinte, a personagem apresenta a seguinte atividade: Diana, essa é a tabela que a minha professora de Educação Física me mostrou. Será que você consegue encontrar as informações sobre minha idade? Quando achar, clique na bolina ao lado da linha:

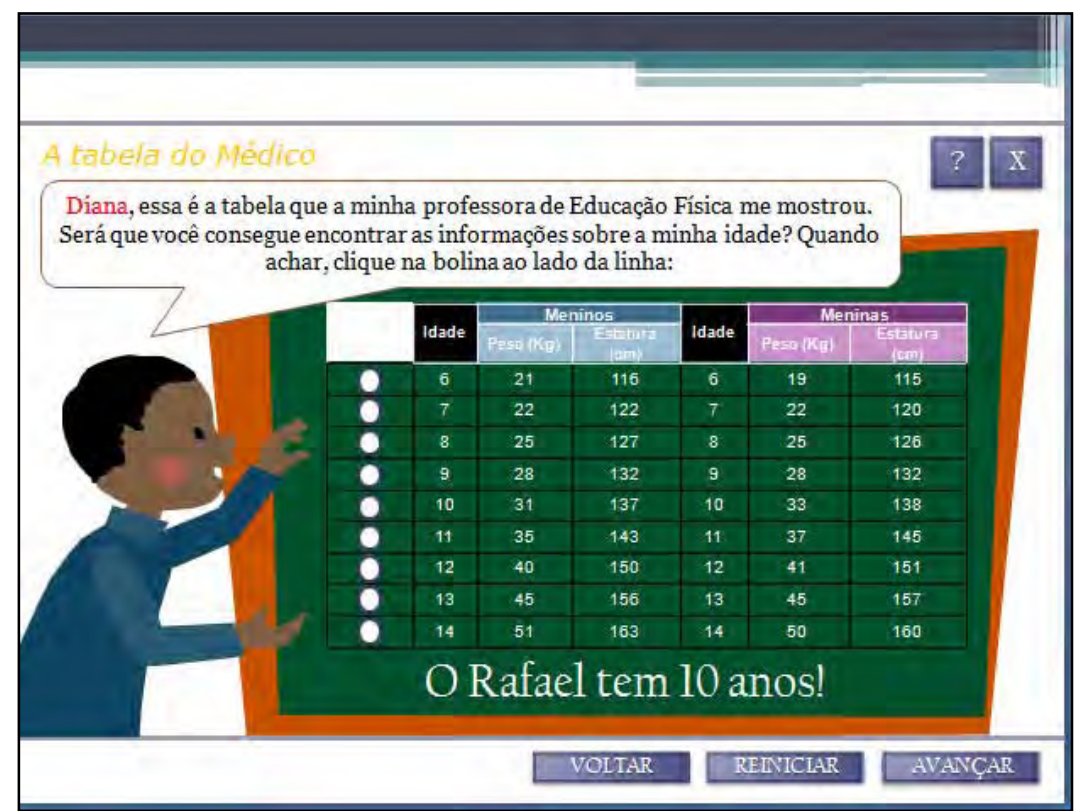

Figura 12 - Tela 4 - Recurso didático informatizado - PMA

Com isso, o aluno começa suas ações de interação com o recurso. Antes de iniciar a construção propriamente dita da tabela, o aluno percorrerá um caminho que priorizará 
primeiramente o entendimento de uma tabela, com o que se espera fornecer subsídios para a construção da mesma.

PMA, diante das análises, inicia a atividade com a turma pela análise da tabela entregue. Porém, o que foi verificado é que a resposta, bem como o entendimento sobre os repertórios dos alunos para responder as questões, configuraram ações que: ou foram realizadas por PMA ou mostraram-se independentes em relação à obtenção de medidas sobre os desempenhos dos alunos.

A proposta desta tela é que o aluno aponte, na tabela exibida, qual a linha da tabela que contém os dados correspondentes à idade de 10 anos. Ainda que esta atividade tenha seu planejamento muito próximo do planejamento identificado pelas análises das aulas ministradas, acredita-se que a mudança do meio pela qual a mesma ocorre, bem como o planejamento que prioriza a ação do aluno, poderão interferir de maneira a modificar como as interações entre aluno - conteúdo - professor acontecem.

Nesta tela, o aluno deverá compor a resposta (Skinner, 1964; p. 31) para escolher entre as alternativas apresentadas, sendo que para compor, será necessário que o aluno lembre-se de informações anteriormente fornecidas: a personagem tem 10 alunos e é masculino. O aluno terá duas oportunidades para responder corretamente a questão. Caso contrário, o recurso o direcionará a uma revisão sobre Tabela.

Na primeira tentativa, o feedback para o aluno será mostrado da seguinte forma:

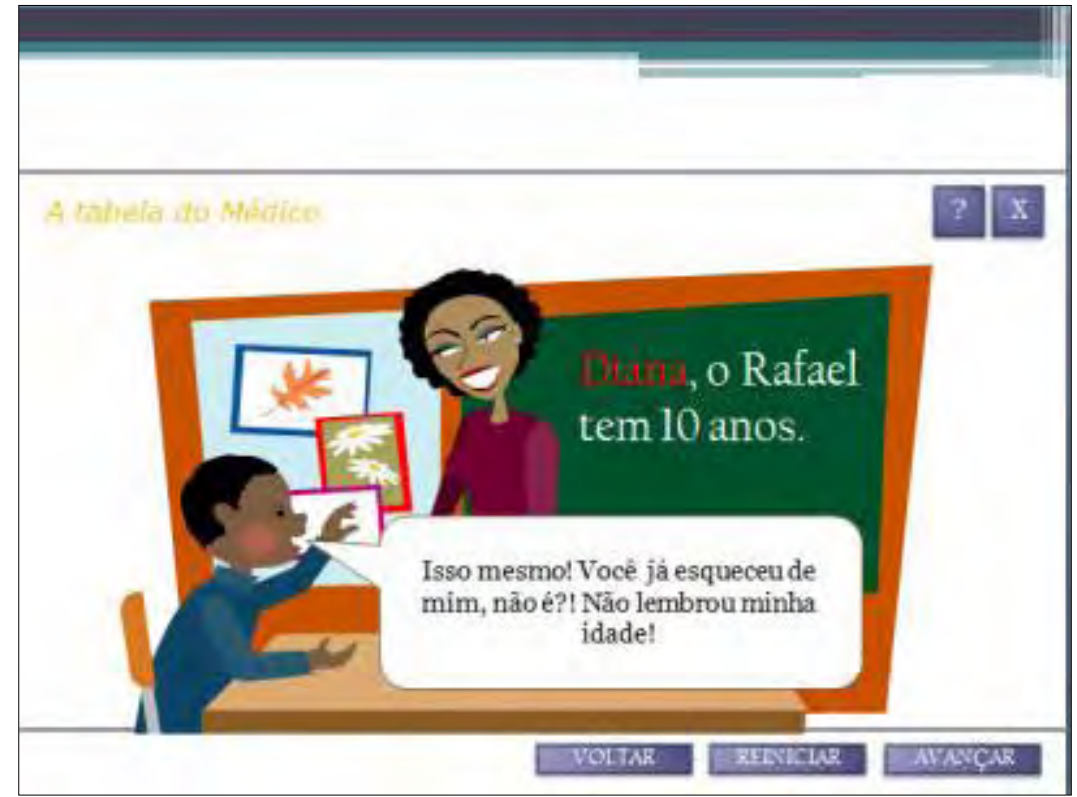

Figura 13 - Tela de Feedback - Recurso didático informatizado - PMA 
$\mathrm{Na}$ segunda tentativa, o recurso redirecionará o aluno à tela de revisão sobre Tabela. A tela que será exibida está exemplificada a seguir:

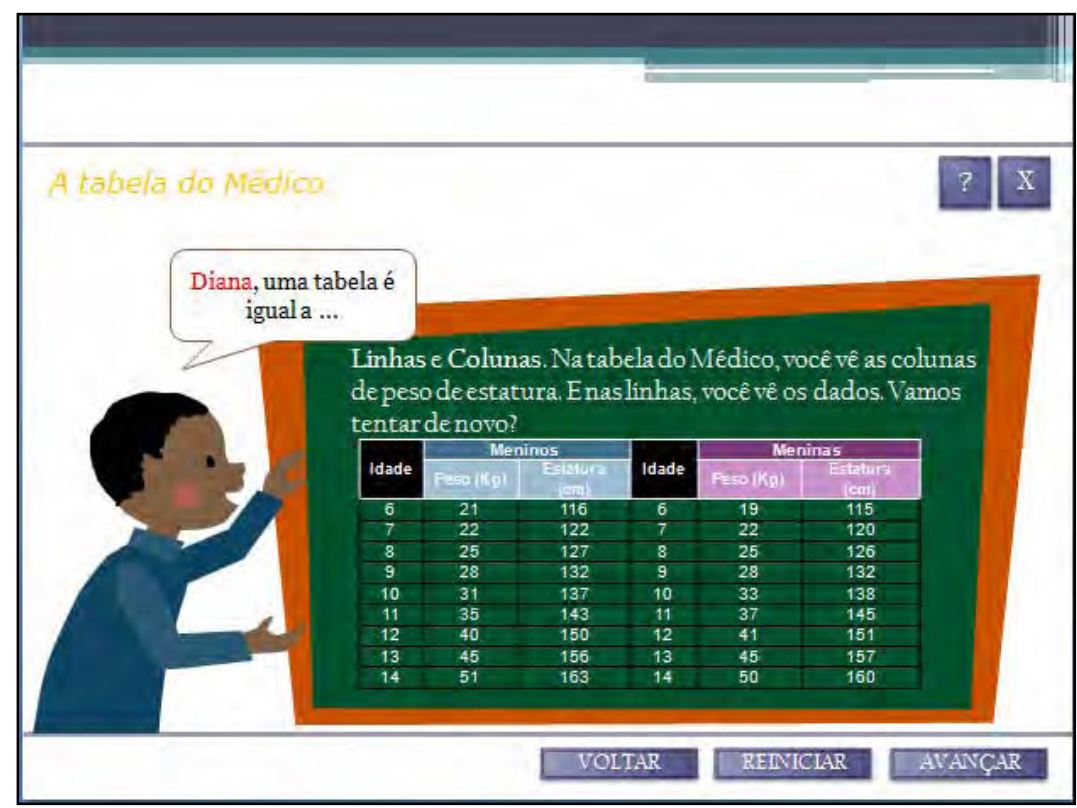

Figura 14 - Tela de Revisão sobre Tabela - Recurso didático informatizado - PMA

Na tela da Figura 14, o aluno deverá acompanhar a explicação que será animada em passo-a-passo, iniciando pela linha, como mostra a sequência de figuras a seguir:

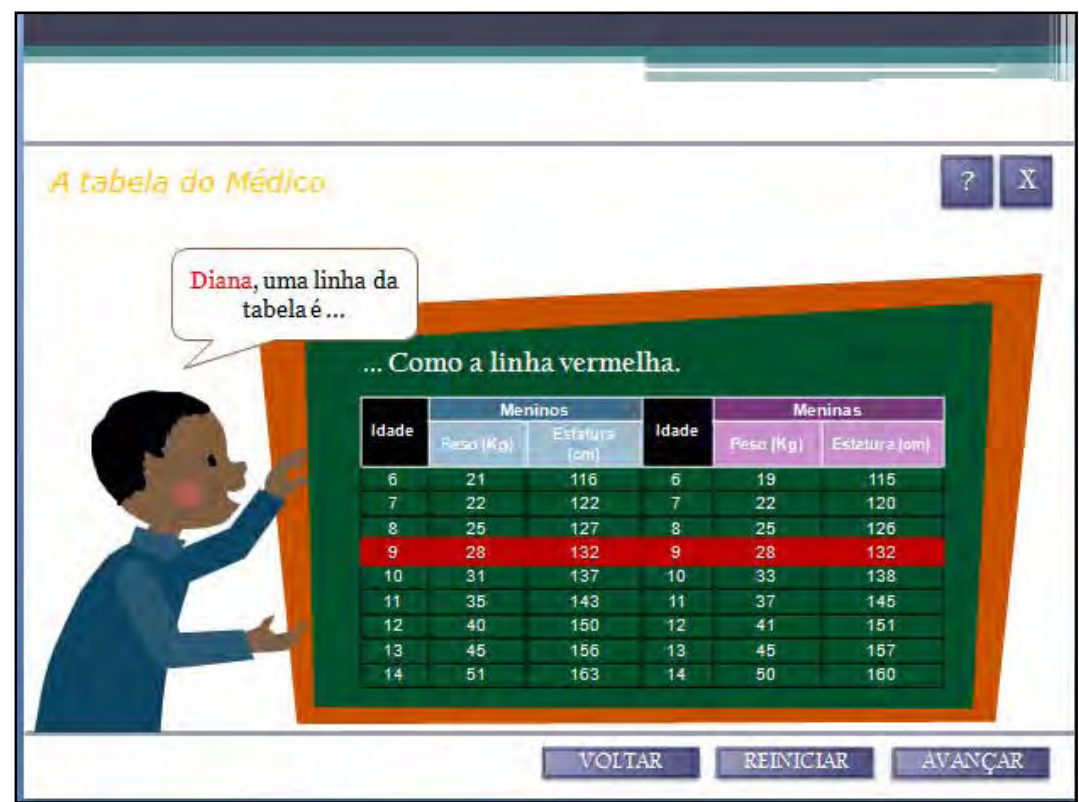

Figura 15 - Tela de Revisão sobre Tabela: Linha - Recurso didático informatizado - PMA 


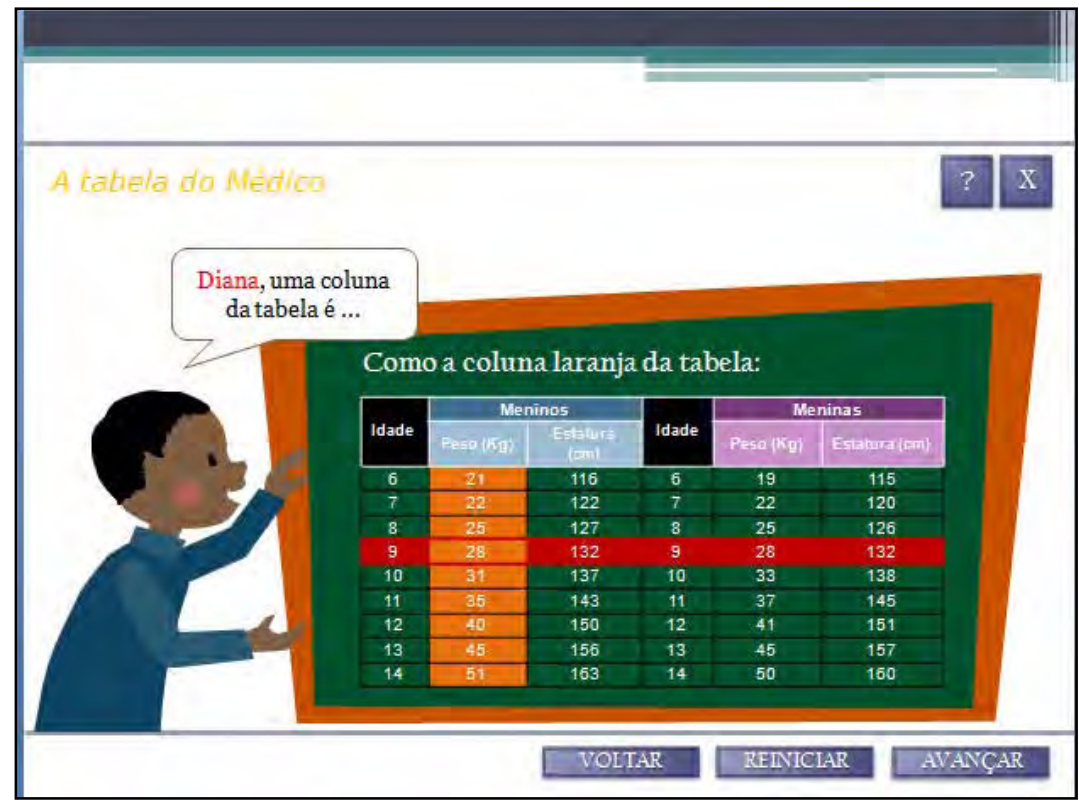

Figura 16 - Tela de Revisão sobre Tabela: Coluna - Recurso didático informatizado - PMA

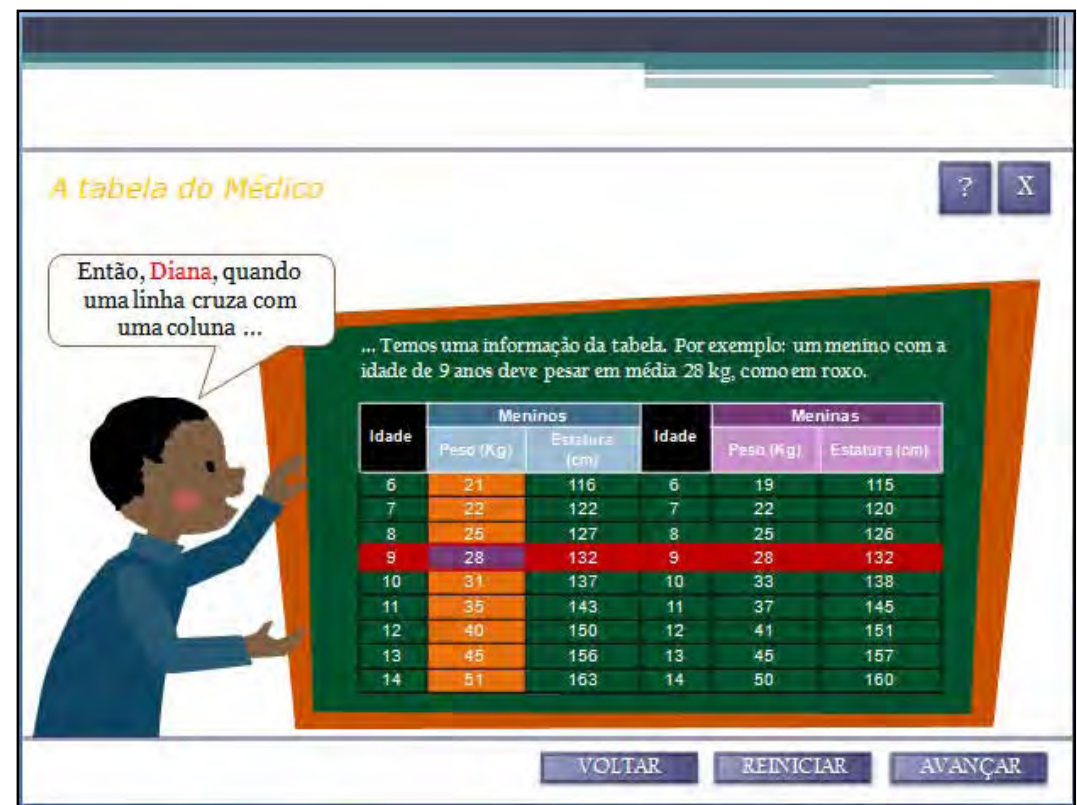

Figura 17 - Tela de Revisão sobre Tabela: Exemplo - Recurso didático informatizado - PMA

O recurso apresenta um resumo sobre o conceito de Tabela, que não explora a construção e a interpretação da mesma neste resumo. PMA, ao perceber recorrência dos comportamentos dos alunos durante a interação dele com o recurso, pode propor novas atividades, realizadas em sala de aula ou não, que explorem a construção de tabelas. O recurso não tem como objetivo esgotar as possibilidades, mas apresentar um exemplo. Uma das possibilidades de uso deste recurso seria como atividade posterior a aulas ministradas em sala 
de aula sobre este tema. Ao finalizar a apresentação do resumo sobre Tabela, o recurso retorna para a atividade apresentada na Figura 12, no qual o aluno deve encontrar a linha com as informações de um menino de 10 anos.

Quando o aluno selecionar a linha correspondente à idade de 10 anos, o recurso foi programado para apresentar a seguinte consequencia imediata à resposta emitida:

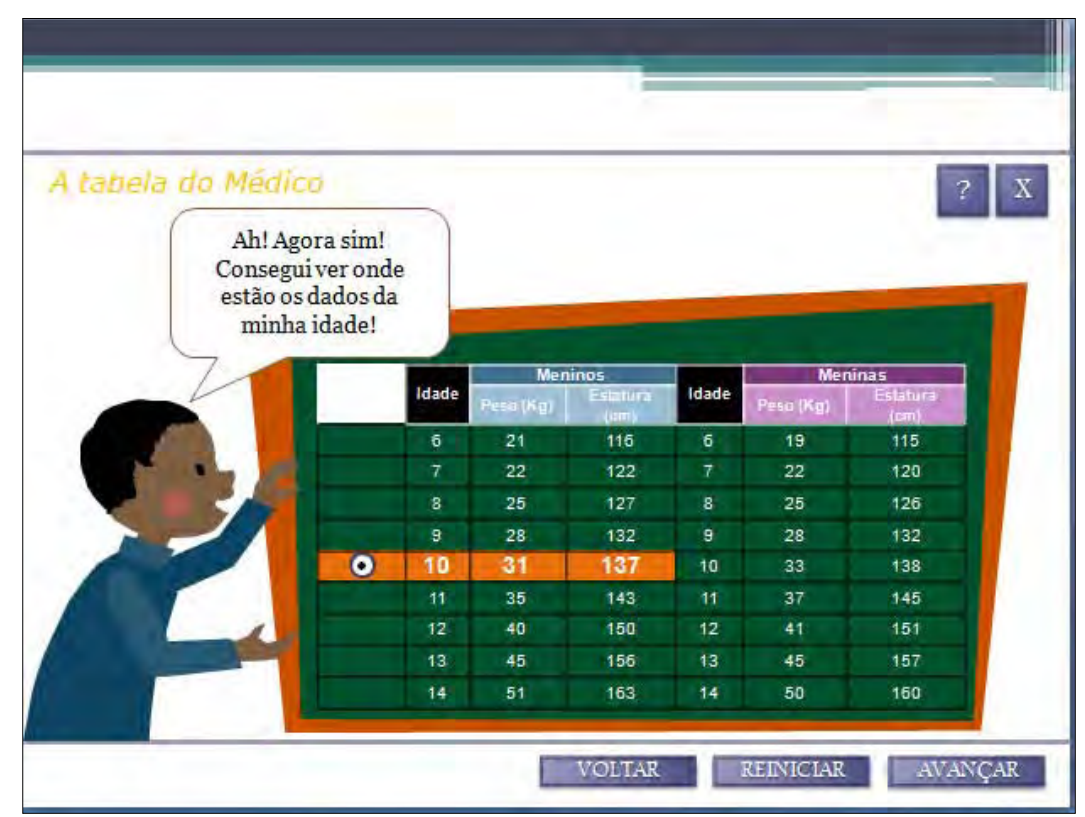

Figura 18 - Tela de Feedback - Recurso didático informatizado - PMA

Emitindo a resposta esperada, o aluno poderá avançar para a próxima tela, o qual o aluno deverá interpretar uma informação requerida pela personagem, ou seja, ao identificar a linha que contém os dados já solicitados, o aluno deverá ler novamente esta linha da tabela para identificar o peso registrado para a idade da personagem, como parte do desenvolvimento da habilidade de interpretação de informações em uma tabela. O texto em que a personagem fala é: Minha professora de Educação Física disse que peso 26kg. Está certo para minha idade? Clique no sim ou no não. 


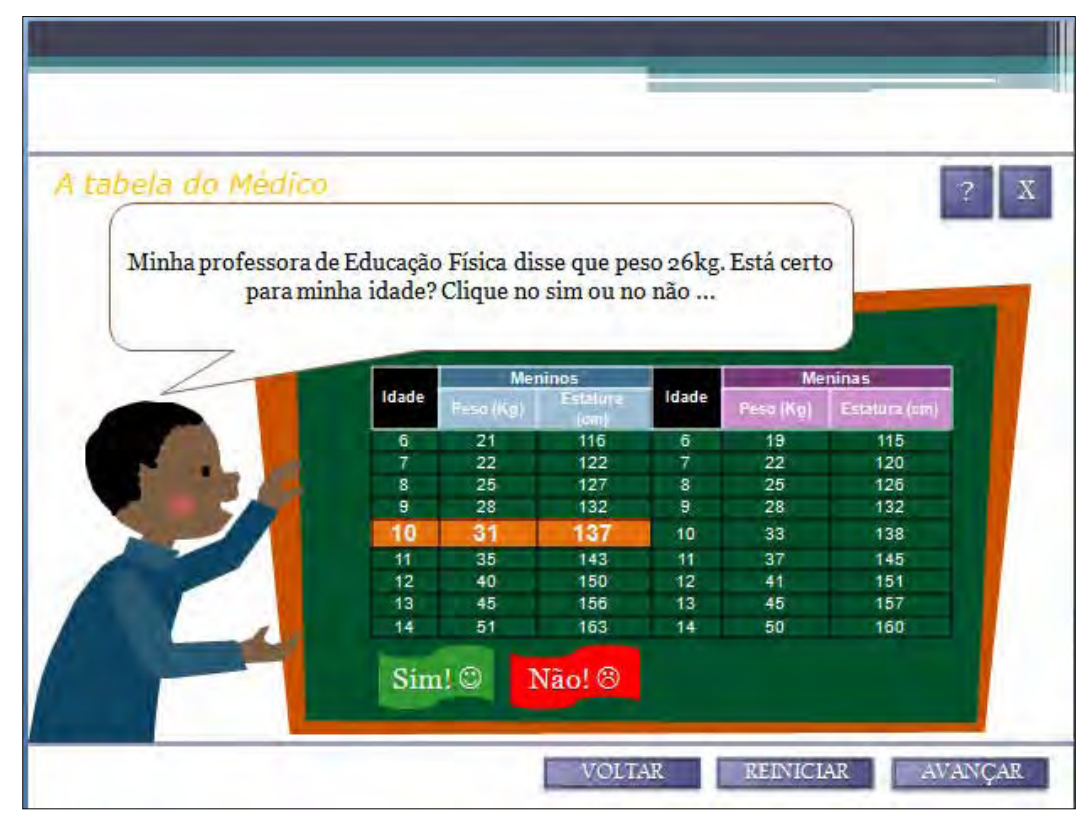

Figura 19 - Tela 5 - Recurso didático informatizado - PMA

O planejamento deste recurso priorizou minimizar algumas das características identificadas durante as análises dos vídeos das aulas ministradas. Uma delas é utilização de estratégias orais em questionamentos muito gerais. O que foi percebido é que os alunos emitiram respostas, muitas vezes, antagônicas e, pela análise, isso aconteceu por conta das condições que foram disponibilizadas por PMA. Então, optou-se, neste recurso, por elaborar questões objetivas que pudessem estabelecer foco para a resposta do aluno, diante da situação elaborada em tela.

A resposta esperada, nesta atividade, é não. Caso o aluno responda incorretamente, o recurso fornecerá o seguinte feedback: 


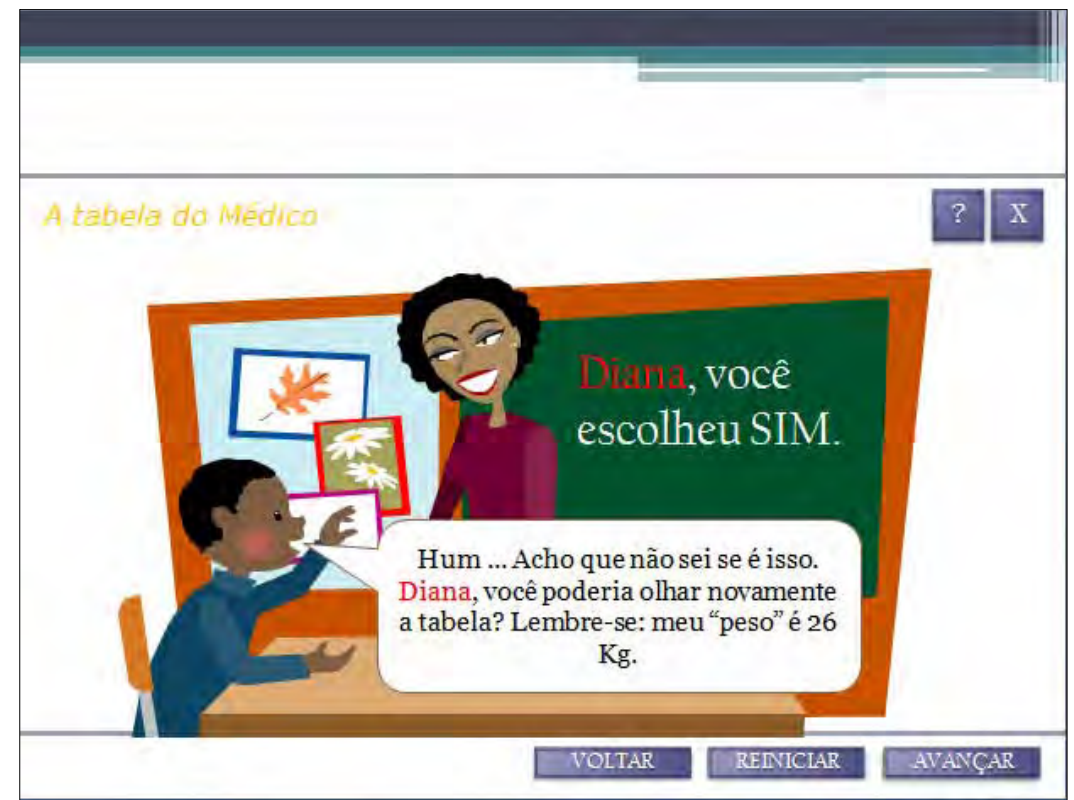

Figura 20 - Tela de Feedback - Recurso didático informatizado - PMA

Caso o aluno responda corretamente:

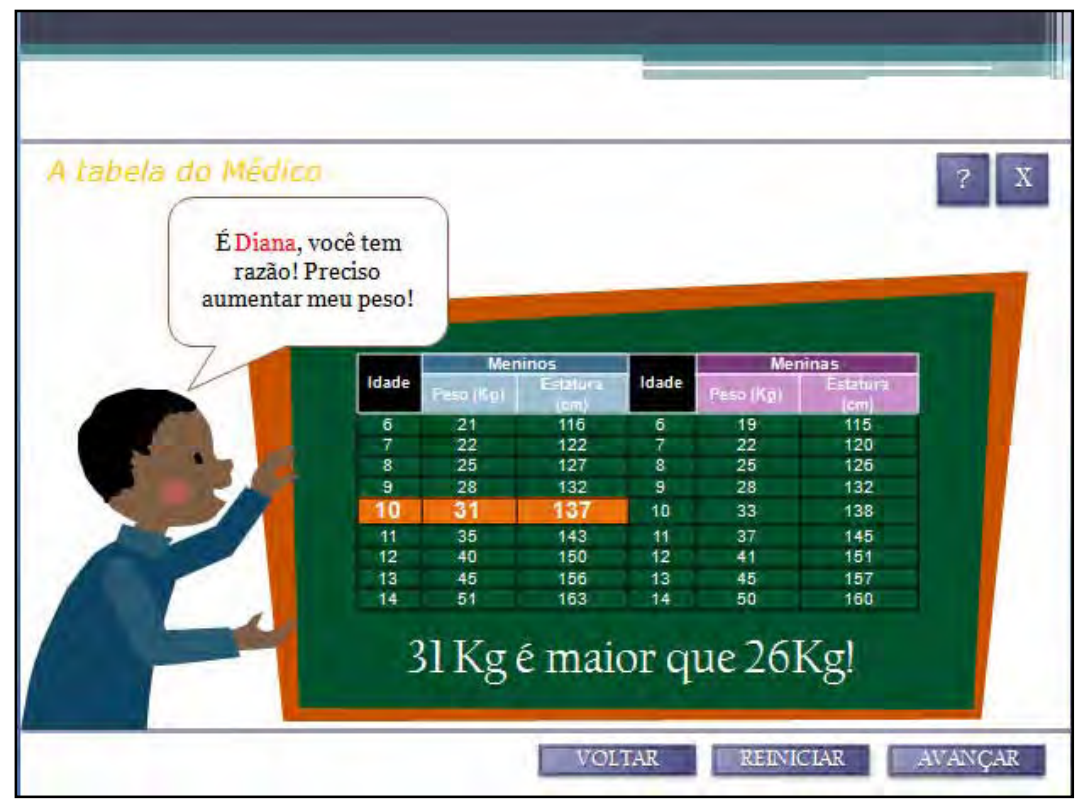

Figura 21 - Tela de Feedback - Recurso didático informatizado - PMA

Ao responder corretamente a questão da atividade, o aluno poderá clicar em Avançar. Novamente, a prioridade da tela exemplificada na Figura 22 é fornecer ao aluno condições de responder uma questão objetiva, cujo foco é ler a questão e, em seguida, analisar a tabela para, então, emitir uma resposta. 


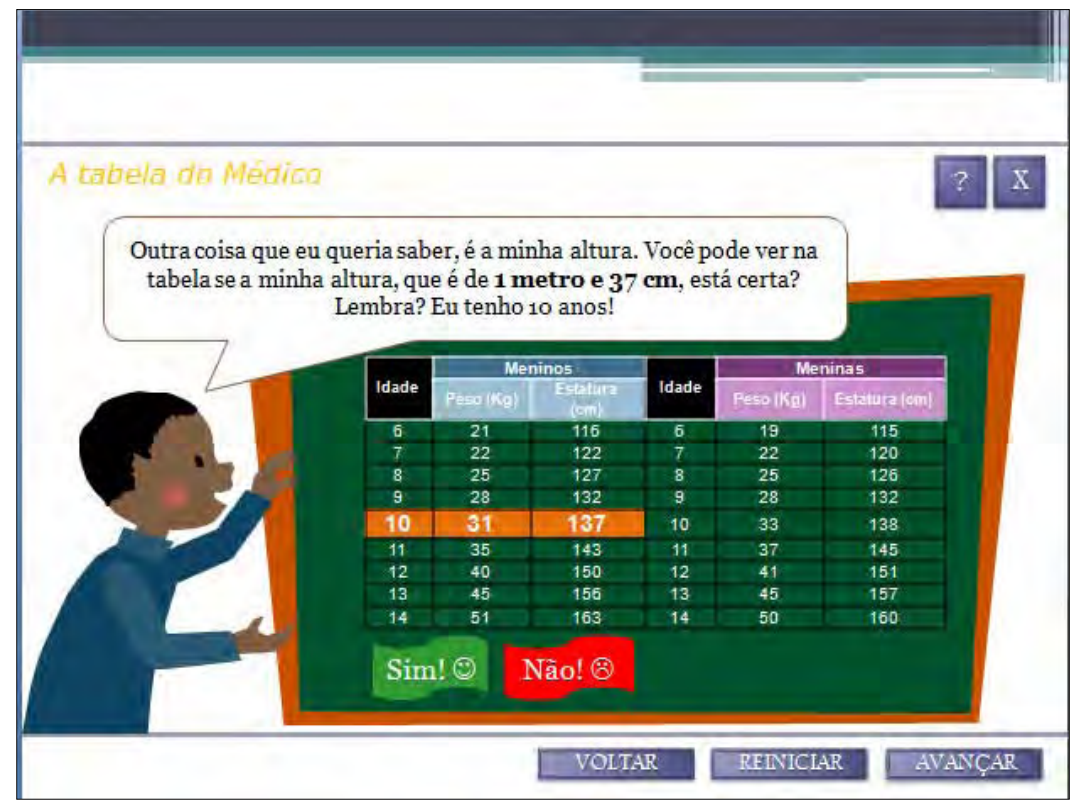

Figura 22 - Tela 6 - Recurso didático informatizado - PMA

Nesta próxima atividade, o aluno deverá emitir uma resposta relacionada às medidas de comportamento, ou seja, seu desempenho deve fornecer subsídios para o professor avaliar o seu entendimento sobre as habilidades relacionadas ao Tema 3. Novamente, o aluno terá duas oportunidades para responder a atividade. Caso o aluno não emita a resposta esperada, o seguinte feedback será fornecido:

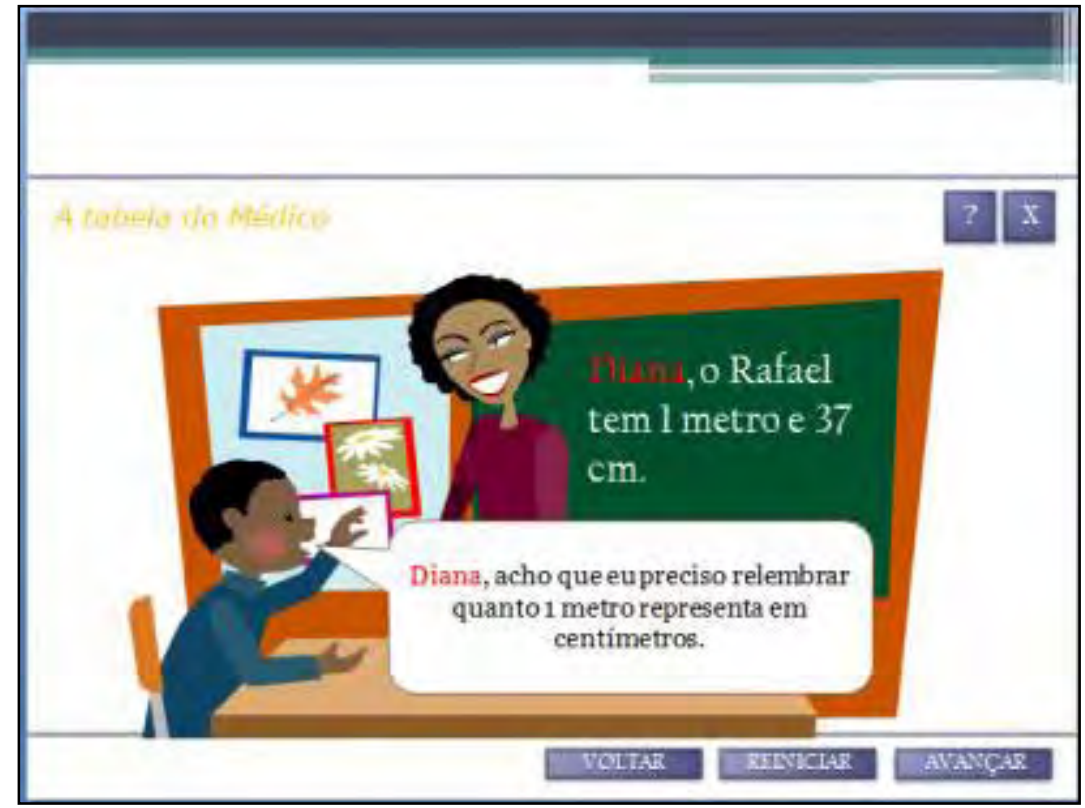

Figura 23 - Tela de Feedback - Recurso didático informatizado - PMA 
Se o aluno novamente emitir uma resposta não esperada para a atividade, uma revisão sobre a conversão de medidas de unidade será apresentada pelo recurso. Depois desta revisão, o aluno é direcionado à atividade proposta pelo recurso e exemplificada na Figura 22 e, ao emitir a resposta correta:

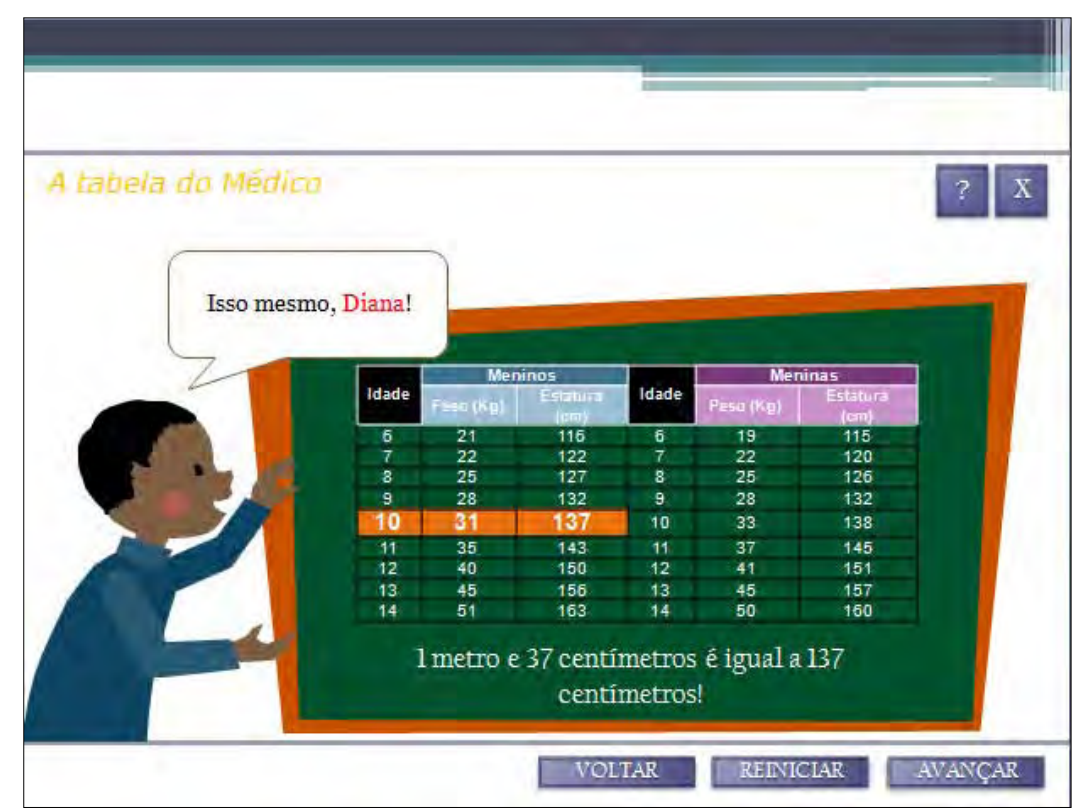

Figura 24 - Tela de Feedback - Recurso didático informatizado - PMA

Ao identificar as informações solicitadas pela personagem, será apresentada uma nova atividade, na qual o aluno deverá indicar qual coluna da tabela poderá ser omitida.

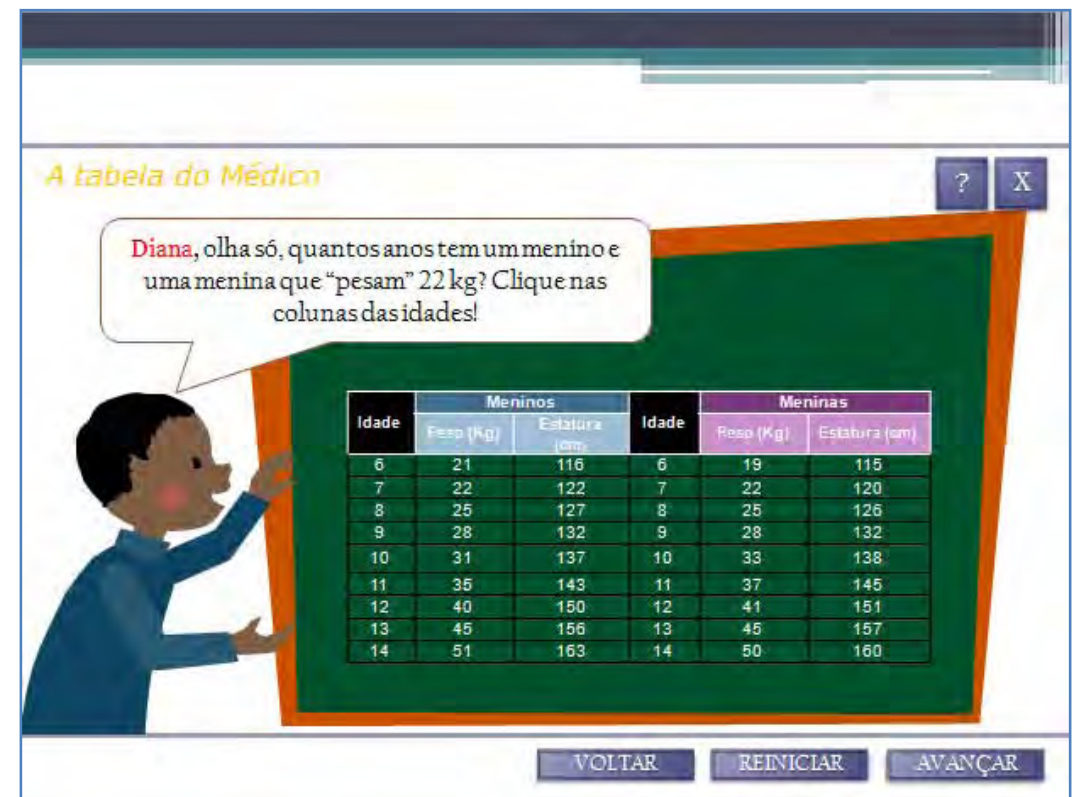

Figura 25 - Tela 7 - Recurso didático informatizado - PMA 
A personagem introduzirá a questão a ser respondida na atividade: Diana, olha só, quantos anos tem um menino e uma menina que "pesam" $22 \mathrm{~kg}$ ? Clique nas colunas das idades!. Nesta atividade, espera-se que o aluno aponte na tabela a idade correspondente aos dados apresentados pela personagem. Caso o aluno não emita a resposta esperada, o feedback solicitará que ele realize novamente a atividade.

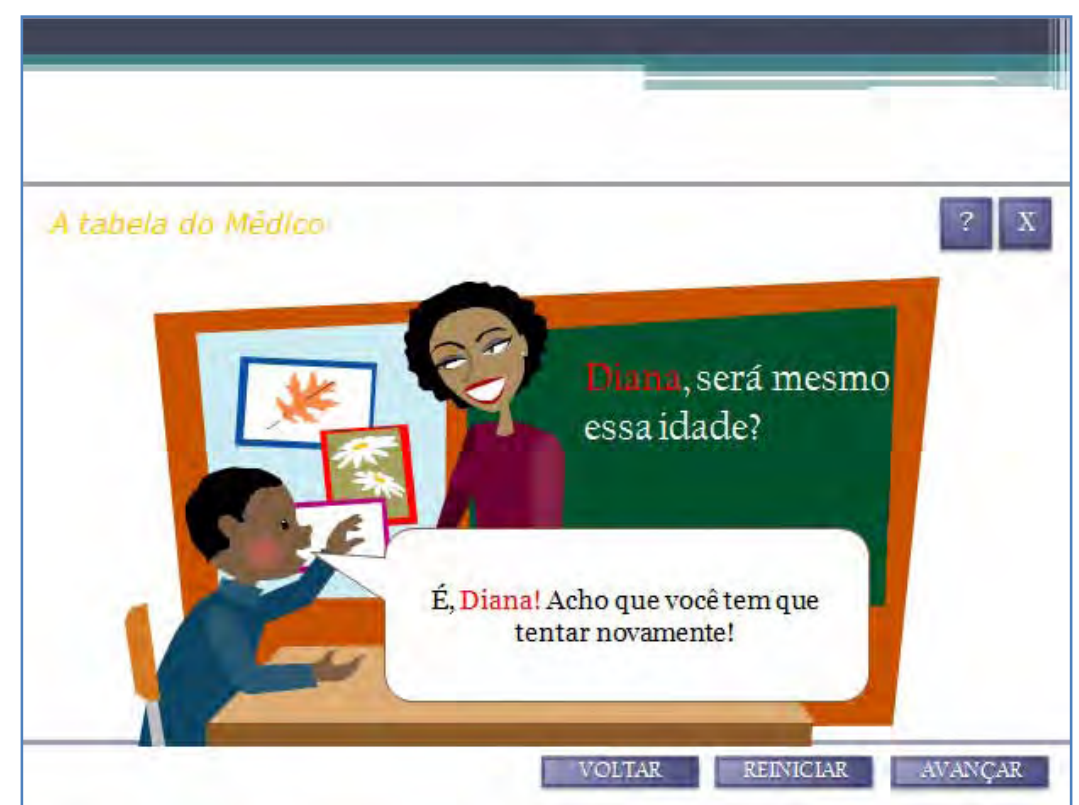

Figura 26 - Tela de Feedback - Recurso didático informatizado - PMA

Sucessivamente, o recurso apresentará mais 4 questões, cujo objetivo é fazer com que o aluno analise os dados fornecidos, os reconheça na tabela e os associe à idade, tanto das meninas, quanto dos meninos. Ao final das quatro respostas esperadas, o aluno verá a tela (Figura 27) preenchida.

Como próximo passo, a personagem solicitará ao aluno para encontrar a sua idade e anotar no caderno a massa corporal e a estatura, correspondente à sua idade. 


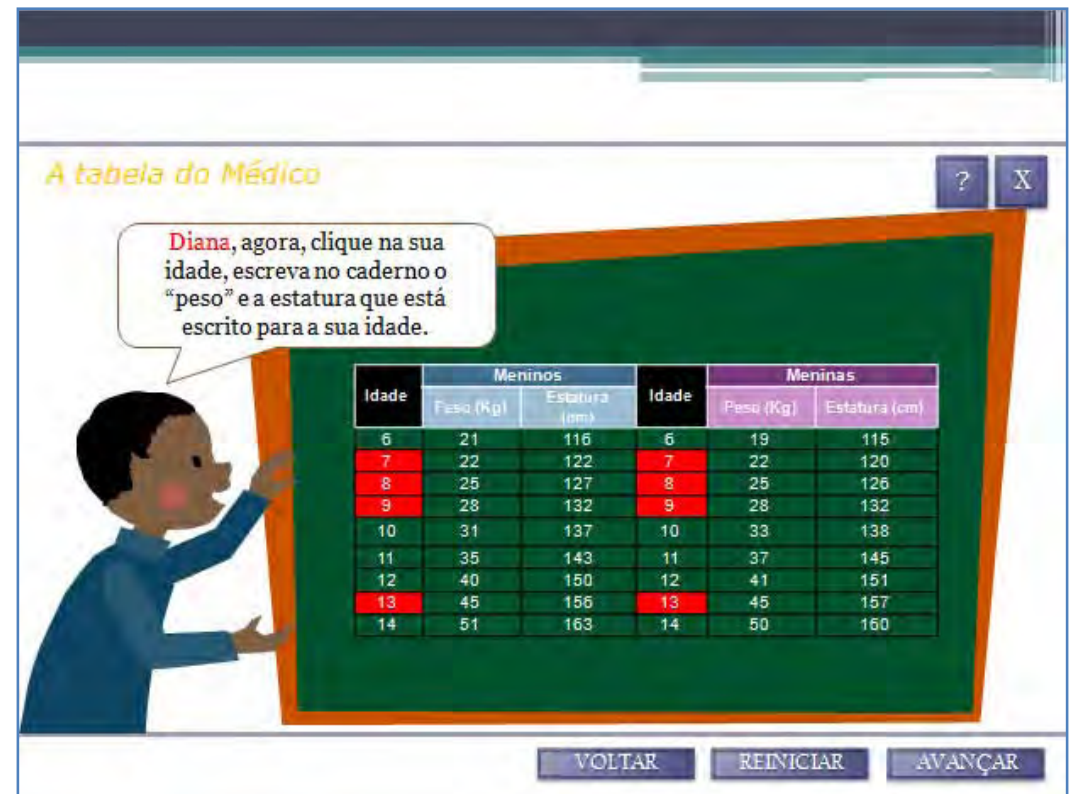

Figura 27 - Tela 8 - Recurso didático informatizado - PMA

Quando o aluno responder corretamente a questão, a personagem, novamente, introduzirá a seguinte atividade: Agora, você acha que essa tabela pode ficar com apenas uma coluna de Idade?. O objetivo desta atividade é que o aluno observe que a coluna idade é igual tanto para os meninos, quanto para as meninas. Porém, demais colunas da tabela, apresentam dados diferentes. A continuidade das análises pode ser criada pelo professor.

Com esta atividade, encerram-se os conteúdos a serem disponibilizados por meio do recurso. Na última tela, é apresentado apenas um fechamento das atividades do recurso:

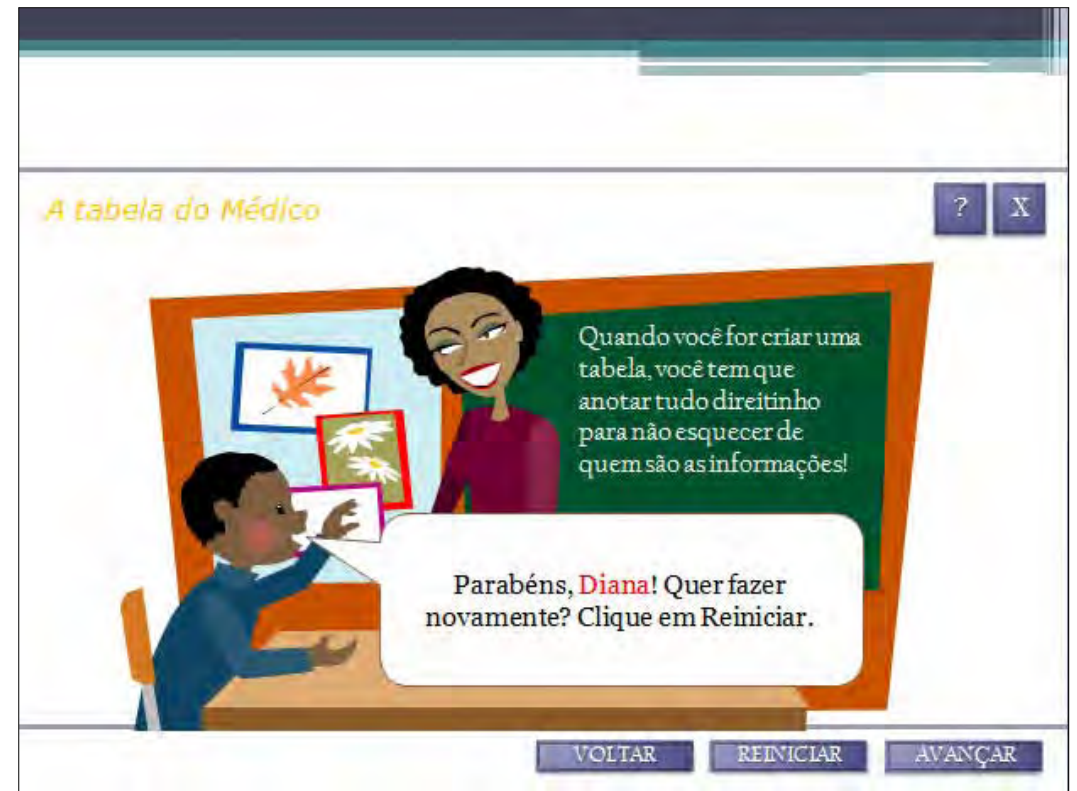

Figura 28 - Tela 9 - Recurso didático informatizado - PMA 
Com isso, a proposta delineada para PMA, embora não modifique o tema principal, teve como objetivo fornecer condições com as quais os alunos poderiam interagir para que eles próprios elaborassem suas respostas.

\begin{tabular}{|c|c|c|}
\hline Ações propostas & $\begin{array}{c}\text { Descrição das Habilidades - } \\
\text { SARESP }\end{array}$ & $\begin{array}{c}\text { Interações favorecidas e Recursos } \\
\text { providos }\end{array}$ \\
\hline $\begin{array}{l}\text { 1. O aluno deve se identificar } \\
\text { no recurso; } \\
\text { 2. O aluno identifica } \\
\text { informações na tabela, que } \\
\text { estão relacionadas a } \\
\text { personagem Rafael (Telas } \\
3 \text { a 7); } \\
\text { 3. O aluno identifica, na } \\
\text { tabela, informações para } \\
\text { unir as tabelas (Telas } 8 \text { a } \\
\text { 10). }\end{array}$ & $\begin{array}{l}\text { Habilidades do Grupo III - } \\
\text { Competências para } \\
\text { Compreender: } \\
\text { - } \quad \text { H29. Ler e/ou interpretar } \\
\text { informações e dados } \\
\text { apresentados em tabelas e } \\
\text { construir tabelas. }\end{array}$ & $\begin{array}{l}\text { Interações entre professor - } \\
\text { aluno e aluno-aluno na } \\
\text { resolução das atividades. } \\
\text { O aluno interage com o } \\
\text { computador, utilizando o } \\
\text { recurso didático elaborado. } \\
\text { PMA pode utilizar de } \\
\text { exposição oral e escrita na } \\
\text { lousa ou meio digital para } \\
\text { explicar o recurso elaborado. } \\
\text { PMA deve acompanhar os } \\
\text { comportamentos dos alunos } \\
\text { durante as resoluções dos } \\
\text { exercícios dos alunos, } \\
\text { identificando informações } \\
\text { contingentes às repostas } \\
\text { emitidas que a permitam } \\
\text { arranjar essas contingências, } \\
\text { mesmo durante a aula. }\end{array}$ \\
\hline
\end{tabular}

Quadro 3 - Programação do Ensino - PRA - UD-01

\subsection{Recurso didático informatizado para PRA}

PRA, nas duas Unidades Didáticas (UD) analisadas neste trabalho, ministrou conteúdos referentes ao mesmo tema, sendo a UD - 01 intitulada de Teorema de Pitágoras: demonstração e interpretação e a UD - 02 intitulada de Aplicação do Teorema de Pitágoras.

Para o delineamento da proposta para recurso didático informatizado, devido à proximidade dos temas ministrados e também às características da prática de ensino de PRA identificadas a partir das análises, a pesquisadora decidiu em elaborar um recurso, apresentado a seguir. 


\subsubsection{Etapa 4.1 - Descrever a programação do ensino das UDs - PRA}

De acordo com as análises realizadas, a programação do ensino planejada por PRA em sua Unidade Didática (UD) - 01 apresenta o seguinte plano, identificado nos registros em vídeo:

\begin{tabular}{|c|c|c|}
\hline Ações de PRA - UD01 & $\begin{array}{c}\text { Descrição das Habilidades - } \\
\text { SARESP }\end{array}$ & $\begin{array}{l}\text { Interações favorecidas e } \\
\text { Recursos providos }\end{array}$ \\
\hline $\begin{array}{l}\text { 1. Demonstração do Teorema } \\
\text { de Pitágoras por meio do } \\
\text { cálculo de área das malhas } \\
\text { quadriculadas; } \\
\text { 2. Resolução de exercícios } \\
\text { sobre o Teorema de } \\
\text { Pitágoras. }\end{array}$ & $\begin{array}{l}\text { - Em \#1, PRA expõe uma única } \\
\text { demonstração sobre o Teorema de } \\
\text { Pitágoras, favorecendo, diante da } \\
\text { demonstração selecionada, o } \\
\text { desenvolvimento da H39 (GII). } \\
\text { - O restante de sua aula foi baseada } \\
\text { na resolução de vários exercícios } \\
\text { sobre o Teorema abordado, sendo } \\
\text { que em alguns registros foi } \\
\text { possível identificar } \\
\text { favorecimento de algumas } \\
\text { habilidades parametrizadas pelo } \\
\text { SARESP, tais como: H19 (GIII) e } \\
\text { H24 (GII). }\end{array}$ & 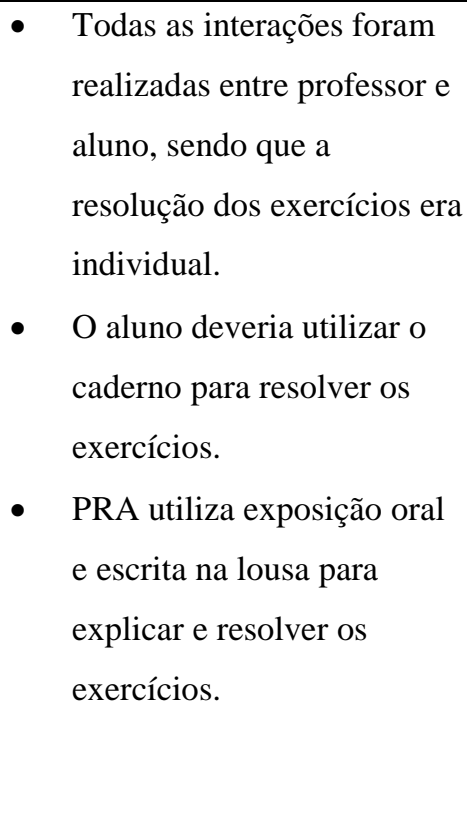 \\
\hline
\end{tabular}

Quadro 4 - Programação do Ensino - PRA - UD-01

Já para a Unidade Didática (UD) - 02 de PRA foi observada a seguinte Programação do Ensino:

\begin{tabular}{|c|c|c|}
\hline Ações de PRA - UD02 & $\begin{array}{c}\text { Descrição das Habilidades - } \\
\text { SARESP }\end{array}$ & $\begin{array}{l}\text { Interações favorecidas e } \\
\text { Recursos providos }\end{array}$ \\
\hline 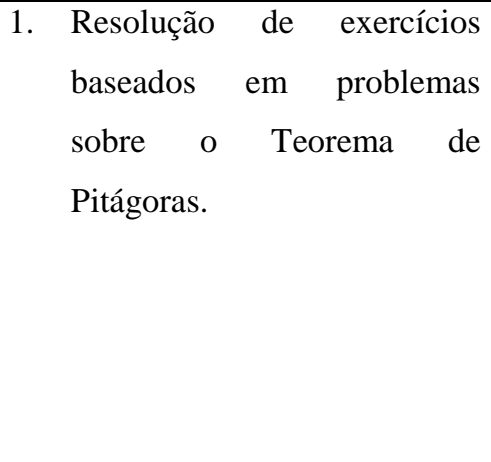 & $\begin{array}{l}\text { - Sua aula foi baseada na resolução } \\
\text { de vários exercícios sobre o } \\
\text { Teorema abordado, sendo que nos } \\
\text { registros analisados foi possível } \\
\text { identificar o favorecimento da } \\
\text { habilidade parametrizada pelo } \\
\text { SARESP: H36 (GII). }\end{array}$ & $\begin{array}{l}\text { - } \text { Todas as interações foram } \\
\text { realizadas entre professor e } \\
\text { aluno, sendo que a } \\
\text { resolução dos exercícios era } \\
\text { individual. } \\
\text { - O aluno deveria utilizar o } \\
\text { caderno para resolver os } \\
\text { exercícios. }\end{array}$ \\
\hline
\end{tabular}




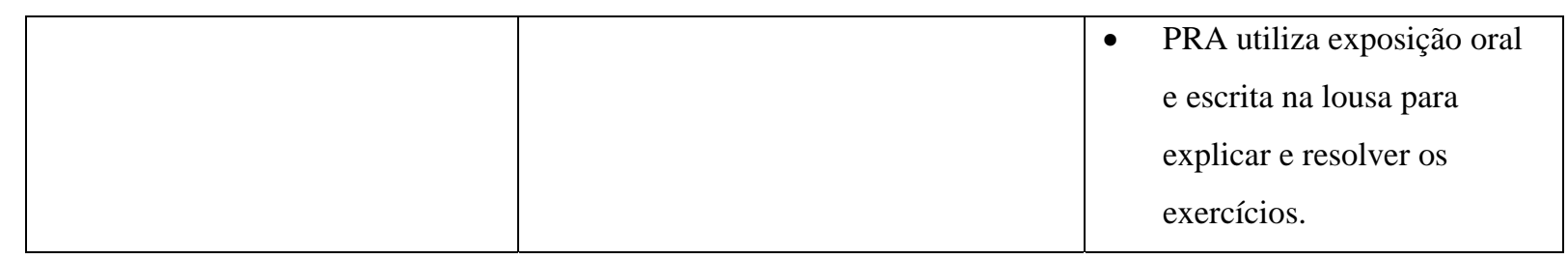

Quadro 5 - Programação do Ensino - PRA - UD-02

\subsubsection{Etapa 4.2 - Elencar as principais características das Práticas de Ensino analisadas}

De acordo com as análises das Unidades Didáticas de PRA, que mostraram-se abordar temas complementares, foi possível observar, a exemplo de PMA, a reincidência de características nas práticas de ensino e de avaliação registradas. Caberia mencionar as seguintes características:

1. Independência de suas ações em relação à obtenção de medidas sobre os desempenhos dos alunos;

2. Utilização de estratégias orais e questionamentos muito gerais;

3. Criação de condições favoráveis para a manifestação de repertórios de comportamentos para a cópia;

4. Medidas de desempenho relacionadas aos resultados sem a preocupação com as fontes de controle de estímulo.

As características da prática de ensino de PRA acima colocadas forneceram dados para o planejamento dos recursos, de modo que, estes recursos, ainda que dependam da ação do professor para sua aplicação e avaliação, poderiam garantir condições para a emissão de repertórios consistentes com as habilidades preconizadas.

\subsubsection{Etapa 4.3 - Delinear o recurso didático informatizado}

Devido às reincidências das características de desempenho de PRA em interações com os alunos e em termos da utilização dos materiais disponíveis, bem como dos conteúdos abordados em suas aulas, a pesquisadora escolheu sistematizar apenas um recurso didático informatizado. 
Na Tabela 38 estão os dados sobre o recurso didático. Alguns desses dados são provenientes das análises realizadas das aulas registradas em vídeo, outros dados são frutos da pesquisa deste trabalho.

Dados do Recurso didático informatizado

\begin{tabular}{|c|c|}
\hline Série/Ano: & Ensino Fundamental - Ciclo II - $8^{\circ} / 9^{\circ}$ ano \\
\hline Disciplina: & Matemática \\
\hline Título: & Desvendando o Teorema de Pitágoras \\
\hline Tema principal: & Grandezas e Medidas \\
\hline Conteúdos ou conceitos envolvidos: & $\begin{array}{l}\text { Relações métricas em triângulos retângulos: Teorema de } \\
\text { Pitágoras. }\end{array}$ \\
\hline Habilidades envolvidas: & $\begin{array}{l}\text { Habilidades do Grupo II - Competências para Realizar: } \\
\text { - H36. Resolver problemas em diferentes contextos, que } \\
\text { envolvam as relações métricas dos triângulos retângulos. } \\
\text { (Teorema de Pitágoras). } \\
\text { Habilidades do Grupo III - Competências para } \\
\text { Compreender: } \\
\text { - H19. Resolver problemas que envolvam equações do } 2^{\text {o }} \\
\text { grau. }\end{array}$ \\
\hline Objetivos do Recurso: & $\begin{array}{l}\text { - Caracterizar as principais propriedades de triângulos } \\
\text { retângulos; } \\
\text { - } \quad \text { Resolver problemas que envolvam relações métricas dos } \\
\text { triângulos retângulos; } \\
\text { - } \\
\text { Aplicar o Teorema de Pitágoras. }\end{array}$ \\
\hline Conhecimentos prévios & $\begin{array}{l}\text { Habilidades do Grupo II - Competências para Realizar: } \\
\text { - } \quad \text { H10. Efetuar cálculos que envolvam operações com } \\
\text { números racionais (adição, subtração, multiplicação, } \\
\text { divisão, potenciação - expoentes inteiros e radiciação); } \\
\text { - } \quad \text { H24. Identificar propriedades de triângulos pela } \\
\text { comparação de medidas de lados e ângulos. } \\
\text { Habilidades do Grupo III - Competências para } \\
\text { Compreender: } \\
\text { - H19. Resolver problemas que envolvam equações do } 2^{\circ} \\
\text { grau. }\end{array}$ \\
\hline Tempo previsto: & 50 minutos. \\
\hline Tecnologias utilizadas: & $\begin{array}{l}\text { Este recurso será desenvolvido utilizando a ferramenta Adobe } \\
\text { Macromedia Flash, que exige a instalação de um plug-in, } \\
\text { disponível na Internet, no endereço: } \\
\text { http://www.adobe.com/br/products/flashplayer/. }\end{array}$ \\
\hline
\end{tabular}


Resumo do Recurso:

Tabela 38 - Recurso didático informatizado - PRA

De acordo com as análises realizadas, entendemos que PRA, em suas aulas ministradas, tinha como objetivo o desenvolvimento/a aquisição das habilidades e competências associadas ao Tema 3: Grandezas e Medidas (Tales, Pitágoras/Áreas, volumes, proporcionalidade / Semelhança / Trigonometria, corpos arredondados), sendo que PRA, especificamente, ministrou sua aula sobre os conteúdos referentes ao Teorema de Pitágoras. Porém, a descrição do Tema 3, segundo o SARESP (GOVERNO DO ESTADO DE SÃO PAULO, 2009a), abrange outros conteúdos que não foram observados. Para a caracterização, foi o tema mais condizente com as práticas analisadas. 
Desta forma, elegemos algumas das habilidades, descritas para os Tema 1: Números, operações, funções (racionais / potenciação, números reais, expressões algébricas, equações, gráficos cartesianos, equações do $2^{\circ}$. grau, funções) e Tema 2: Espaço e Forma, como habilidades que já foram adquiridas, ou seja, de Conhecimentos prévios, pois o assunto tratado na atividade remete o aluno às habilidades relacionadas a estes temas. Sendo assim, como Conhecimentos Prévios, inserimos na tabela acima, as habilidades que os alunos deverão apresentar ao longo do desenvolvimento da atividade proposta.

Com isso, o plano de ensino que norteou o planejamento do recurso toma como ponto de partida que os alunos têm condições de emitir os repertórios consistentes com as habilidades relacionadas aos demais temas, propondo apenas uma recapitulação ou resumo sobre estes conteúdos, como forma de feedback, caso sejam verificadas respostas incorretas em determinadas situações propostas.

Este tipo de planejamento também poderá fornecer informações a PRA que a façam retomar, em sala de aula, os conteúdos previstos para os Temas 1 e 2, em novas elaborações e programações das contingências.

\section{O planejamento do recurso didático informatizado}

É importante observar que as telas apresentadas no recurso elaborado foram redigidas com terminologias em níveis crescentes de complexidade. Assim, a linguagem e os termos utilizados deveriam proporcionar condições para que o aluno emitisse os comportamentos desejados sem necessitar de acesso a outras fontes de informação. Cabe ressaltar que as telas específicas disponibilizaram "links" para acesso à informações estimadas relevantes para garantir a emissão dos comportamentos previstos. Como em uma montagem de apresentação em PowerPoint, são inseridas imagens e textos. Por se tratar de um trabalho voltado para o Ensino Fundamental - Ciclo II é interessante que o conteúdo seja apresentado com cores e movimentos, bem como em uma elaboração de texto que converse com o aluno.

Nesta primeira tela (Figura 29) é apresentado o tema da atividade e realizado um convite ao aluno a participar de uma experiência sobre o conhecimento matemático. Com isso, o aluno tem acesso ao tema principal, bem como uma introdução que o leva a considerar que existirão atividades/exercícios que deverão ser cumpridos ao longo do desenvolvimento da atividade. 
Para "conduzir" a apresentação das atividades previstas e os conteúdos, foi elaborado um personagem, de nome Márcio, que deverá utilizar uma linguagem próxima da linguagem do aluno.

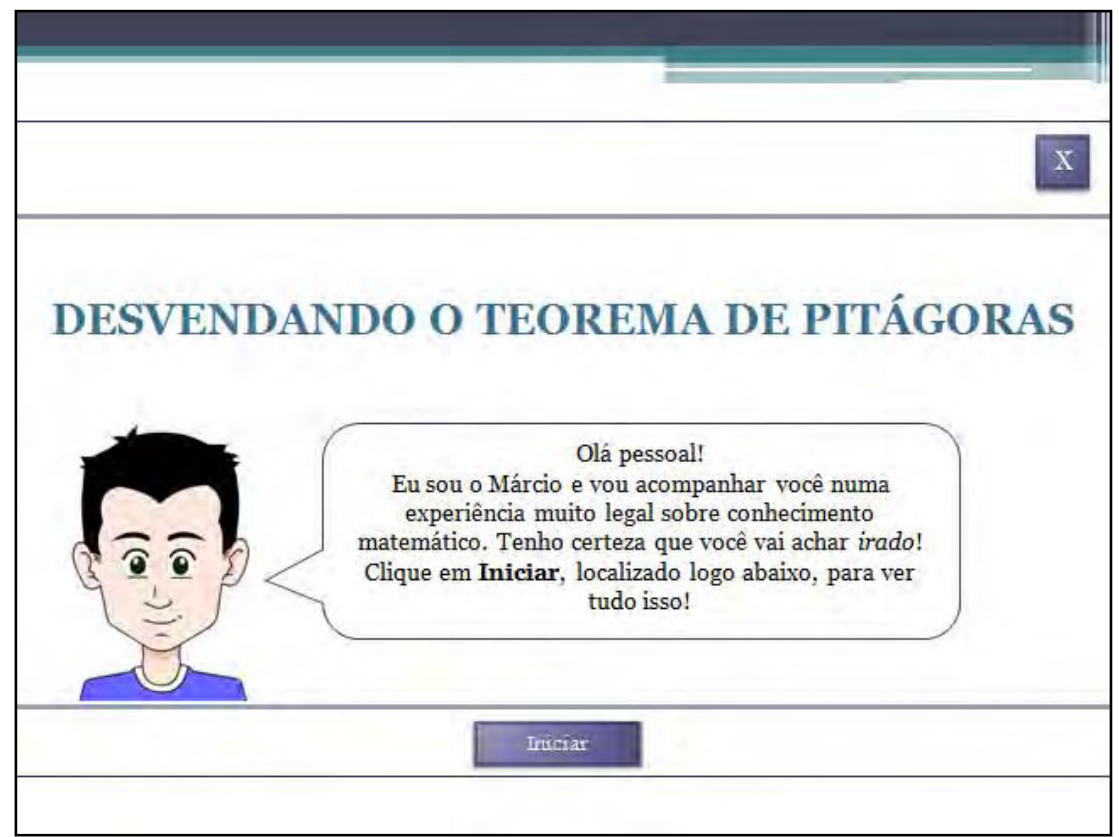

Figura 29 - Tela 1 - Recurso didático informatizado de PRA

Cabe aqui ressaltar que o ritmo no qual essa atividade ocorre está sob o controle do aluno. Sendo assim, quando ele terminar de fazer a leitura do texto impresso na tela, ele poderá clicar no botão Iniciar, o aluno terá acesso à próxima tela, como mostra a Figura 30:

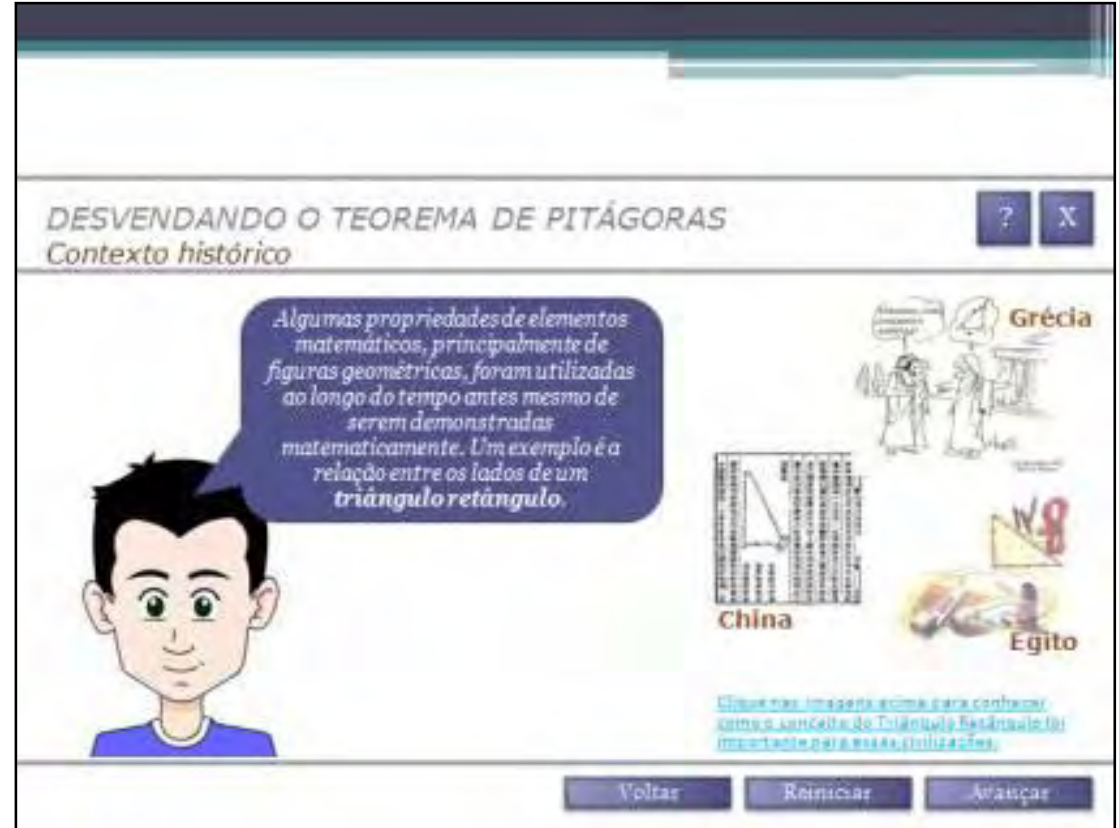

Figura 30 - Tela 2 - Recurso didático informatizado de PRA 
Na tela 2 (Figura 30), a personagem ressalta que a área de Matemática é uma construção histórica, apresentando alguns exemplos em períodos diferentes da nossa história. Para esse recurso, elegemos conteúdos referentes a diferentes civilizações em diferentes momentos da história da humanidade (China, Grécia e Egito).

Este conteúdo disponibiliza possibilidades de exploração de outras habilidades, que não somente aquelas registradas nas análises realizadas aqui para a UD-01 de PRA Competências do Grupo II - que parametrizam as competências para realizar. PRA poderia elaborar um conteúdo, dentro de um plano de ensino, que favorecesse a resolução de problemas envolvendo as propriedades de um triângulo retângulo, remetendo essa resolução a outras épocas de nossa história. Assim, as habilidades a serem desenvolvidas pelos alunos poderiam ser relacionadas às Competências de Grupo III, ou seja, competências para compreender historicamente a construção do conceito matemático.

Ao finalizar a leitura deste material, o aluno poderá clicar em Avançar para visualizar o próximo conteúdo previsto, que propõe uma atividade.

Com esta atividade, o professor terá oportunidade de avaliar quais são as medidas de desempenho do aluno relacionadas à identificação das propriedades que designam um triângulo retângulo.

A atividade apresenta um triangulo retângulo $\mathrm{ABC}$ e o aluno deverá identificar os lados desse triângulo, nomeando os três lados: hipotenusa, cateto e cateto. Além dos lados, o aluno também deverá identificar os ângulos representados na figura: ângulo reto e os dois ângulos agudos. Para a classificação dos ângulos, foi inserido apenas dois espaços de preenchimento. Sendo assim, o aluno deve classificá-los como do mesmo tipo. 


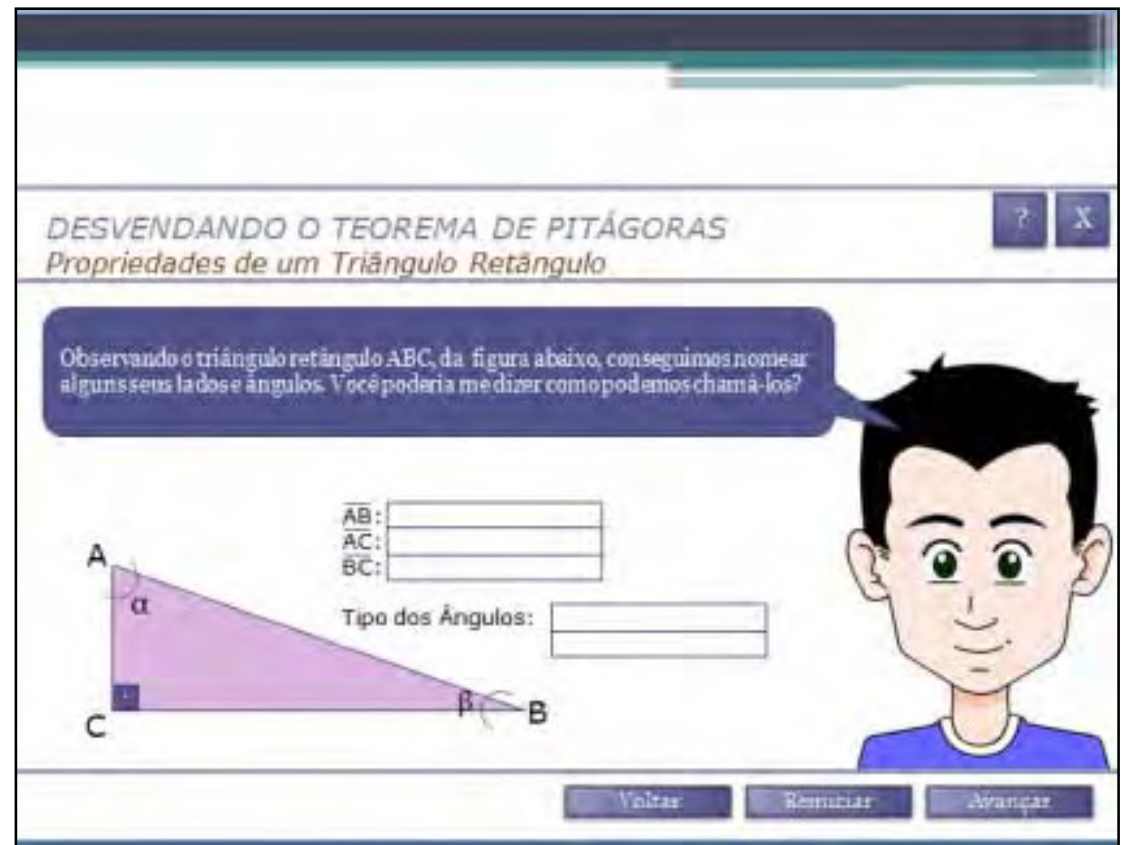

Figura 31 - Tela 3 - Recurso didático informatizado de PRA

Para verificar se as respostas fornecidas estão corretas, o aluno deverá clicar em Avançar. Este botão somente estará disponível se ele preencheu todos os espaços. Se o aluno responder todas as proposições da atividade corretamente, ele será direcionado para a Tela $3 b$ (Figura 32). Nela, ele deverá clicar em Avançar para visualizar a primeira demonstração do Teorema de Pitágoras.

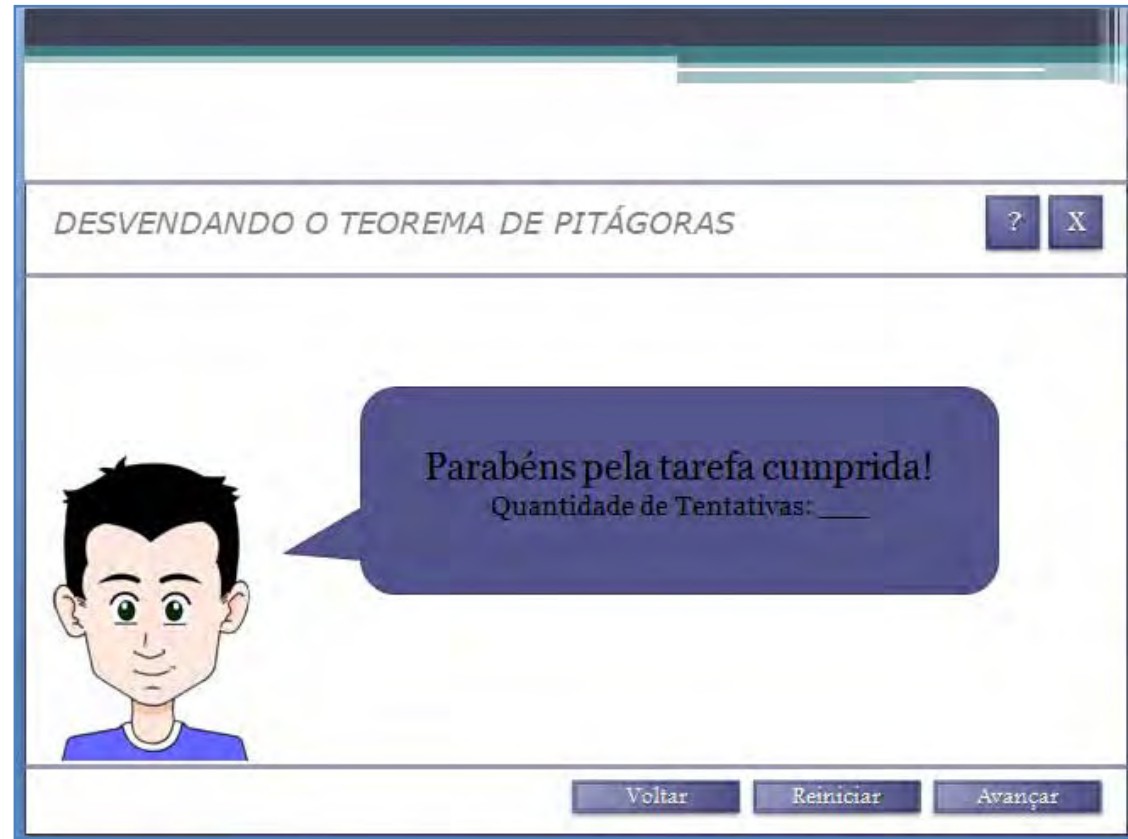

Figura 32 - Tela 3b - Aluno cumpriu a atividade proposta 
Caso o aluno não tenha respondido a atividade corretamente, ele poderá respondêla novamente. Mas, antes, verá a seguinte tela:

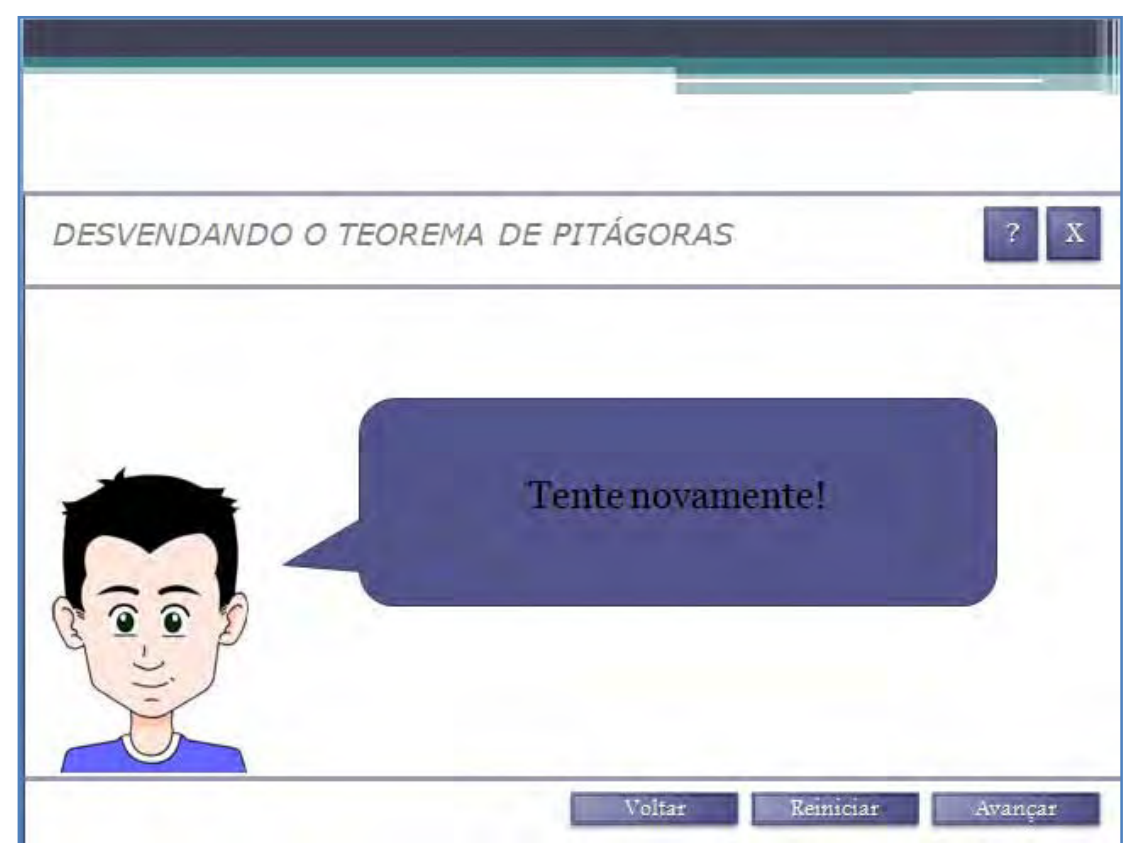

Figura 33 - Tela 3c - Aluno deverá tentar cumprir a atividade novamente

O objetivo desta tela é mostrar as propriedades de um triângulo retângulo. Nesta tela, o texto é apresentado e conforme as propriedades vão sendo explicadas pela personagem, as propriedades do triângulo retângulo representado, correspondentes às falas, serão evidenciadas, tanto na área das tabelas escritas, quanto na figura.

De acordo com a programação do ensino identificada de PRA para a UD-01, a aula é iniciada com uma demonstração do Teorema de Pitágoras. Porém, consideramos que uma revisão sobre as propriedades de um triângulo retângulo é essencial para o entendimento do Teorema a ser aprendido. Sendo assim, o objetivo de incluir as telas 3 e 3 a neste recurso, é fornecer um meio pelo qual o aluno possa ter acesso à um conteúdo de revisão. O item Conhecimentos Prévios dos alunos da tabela de Dados do Recurso Didático Informatizado foi redigido considerando a H24. Identificar propriedades de triângulos pela comparação de medidas de lados e ângulos (GII).

Quando o aluno terminar de ver a apresentação da tela 3a, ele poderá clicar no botão Avançar para ter acesso ao próximo conteúdo. Na próxima tela, o aluno poderá visualizar uma demonstração empírica sobre o Teorema de Pitágoras, sendo esta relacionada ao enunciado: um quadrado construído sobre a medida da hipotenusa tem área igual à soma das áreas dos quadrados construídos sobre os catetos. 
Nesta tela, o aluno deverá interagir com a demonstração com o objetivo de evidenciar que um quadrado construído sobre a medida da hipotenusa tem área igual à soma das áreas dos quadrados construídos sobre os catetos.

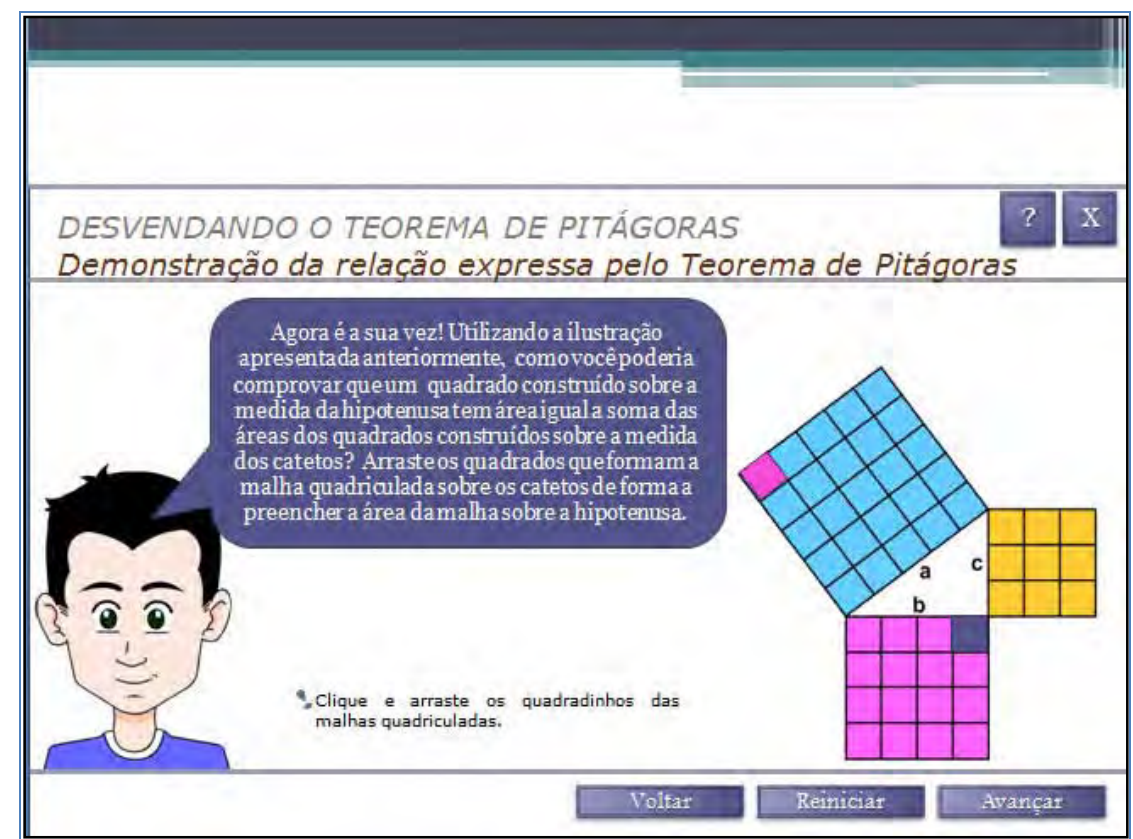

Figura 34 - Tela 4 - Recurso didático informatizado de PRA

O aluno, nesta tela, deverá seguir as instruções fornecidas pela personagem. Todos os quadradinhos que compõem as malhas quadriculadas podem ser arrastados. $\mathrm{O}$ aluno, então, deve arrastá-los para os locais que consideram corretos. Nesta atividade, apenas quando o quadrado arrastado for solto no local correto, é que ele será fixado, ou seja, a consequência da resposta é imediata: o aluno saberá assim que escolher o local onde soltará o quadrado arrastado, se está ou não respondendo corretamente a questão.

Assim que o aluno finalizar esta atividade, ele deverá clicar em Avançar. A próxima tela mostrará o resultado que o aluno produziu. Como demonstração de uma possível resposta, segue a imagem Tela 5 (Figura 35): 


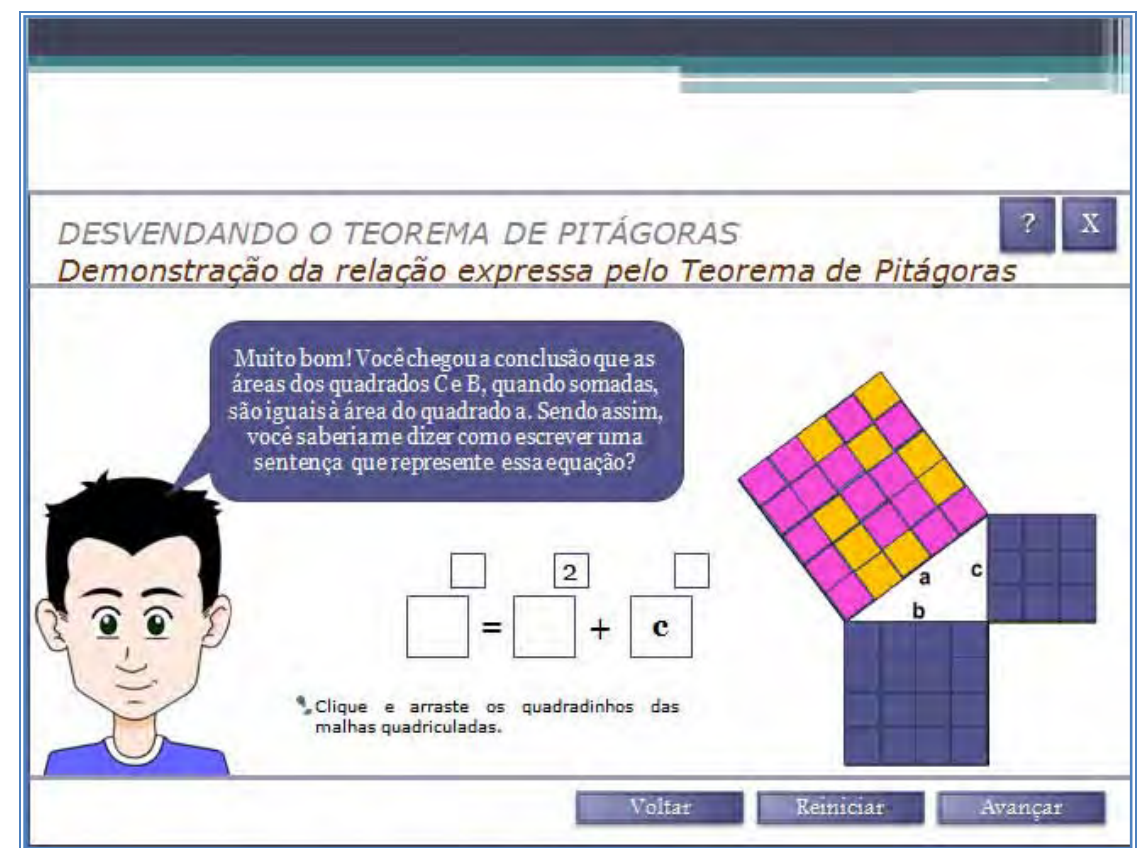

Figura 35 Tela 5 - Recurso didático informatizado de PRA

Os quadrados de lados b e c aparecem não preenchidos, enquanto o quadrado de lado a é representado com as cores dos quadrados b e c. Com o resultado produzido pelo aluno exibido em tela, o próximo passo é inferir a sentença que representa a demonstração apresentada.

O resultado esperado como resposta é a equação de $2^{\circ}$ grau: $\mathbf{a}^{2}=\mathbf{b}^{2}+\mathbf{c}^{2}$. O aluno poderá avançar somente quando preencher todos os espaços reservados para representar a equação. Novamente, essa interação do aluno com o recurso gerará informações contingentes às respostas emitidas. Se o aluno responder corretamente, ele poderá seguir para a próxima tela. Caso contrário, deverá responder novamente o exercício até que a resposta correta seja emitida.

Cabe mencionar, que para a proposta de recurso para PRA utilizamos a mesma demonstração do Teorema de Pitágoras. Porém, neste recurso, a interação com o material didático é do aluno, o que lhe permite realizar (Competências de GII) a atividade proposta. Essa mudança de meio pelo qual as atividades são realizadas pode minimizar algumas das características das práticas de ensino identificadas em PRA, diante de nossas análises, como por exemplo: criação de condições favoráveis para a manifestação de repertórios de comportamentos para a cópia, quando apenas PRA escrevia na lousa a resposta esperada do aluno. 
Ao finalizar a demonstração, o aluno deverá clicar em Avançar. A próxima tela (Figura 36) tem como objetivo mostrar evidências históricas do conhecimento sobre o Teorema de Pitágoras, abordando o conteúdo sobre a resolução de problemas que envolvem este teorema.

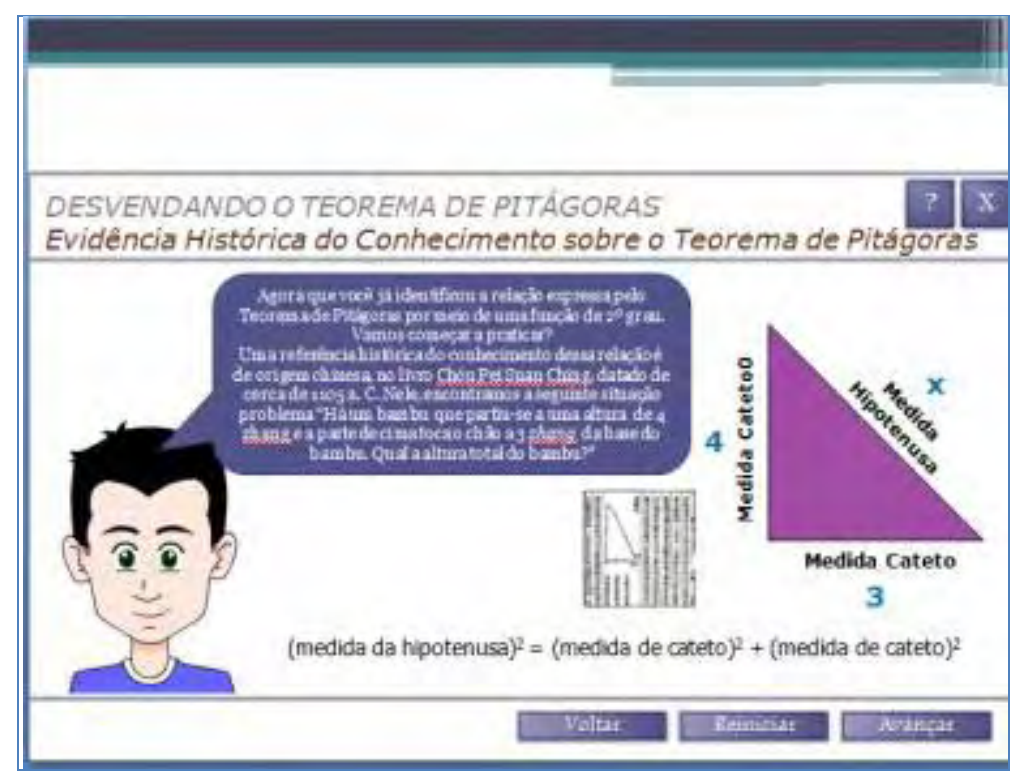

Figura 36 - Tela 6 - Recurso didático informatizado de PRA

Nesta tela, a personagem narra o texto, propondo uma situação problema ao aluno. Ao terminar a leitura da fala do personagem, a imagem com o recorte do livro Chinês citado é apresentada. Em seguida, a personagem volta a narrar um texto: A ilustração que representa essa situação nos lembra uma figura já conhecida: o triângulo retângulo e, em seguida, será apresentada a figura do triângulo retângulo com todas as descrições, que se segue e também está representado na Figura 37:

- 4 = medida de cateto;

- 3 = medida de cateto;

- $\mathrm{X}=$ medida de hipotenusa.

Com o triângulo retângulo e suas descrições postas na tela, o texto (medida da hipotenusa $)^{2}=(\text { medida de cateto })^{2}+(\text { medida de cateto })^{2}$ deverá ser mostrado. Ao finalizar a leitura dessa tela, o aluno poderá ir para o próximo passo.

A próxima tela tem como proposta uma continuação do que foi iniciado na tela anterior. Porém, neste passo o aluno deverá interagir com o recurso apresentado, por meio de uma atividade, na qual insere os valores que tornem verdadeira a resolução de uma situação- 
problema, usando a relação de Pitágoras. Para isso, o aluno deverá digitar, nos locais indicados, os valores numéricos que completam corretamente a sentença matemática, a fim de encontrar a solução para a situação proposta.

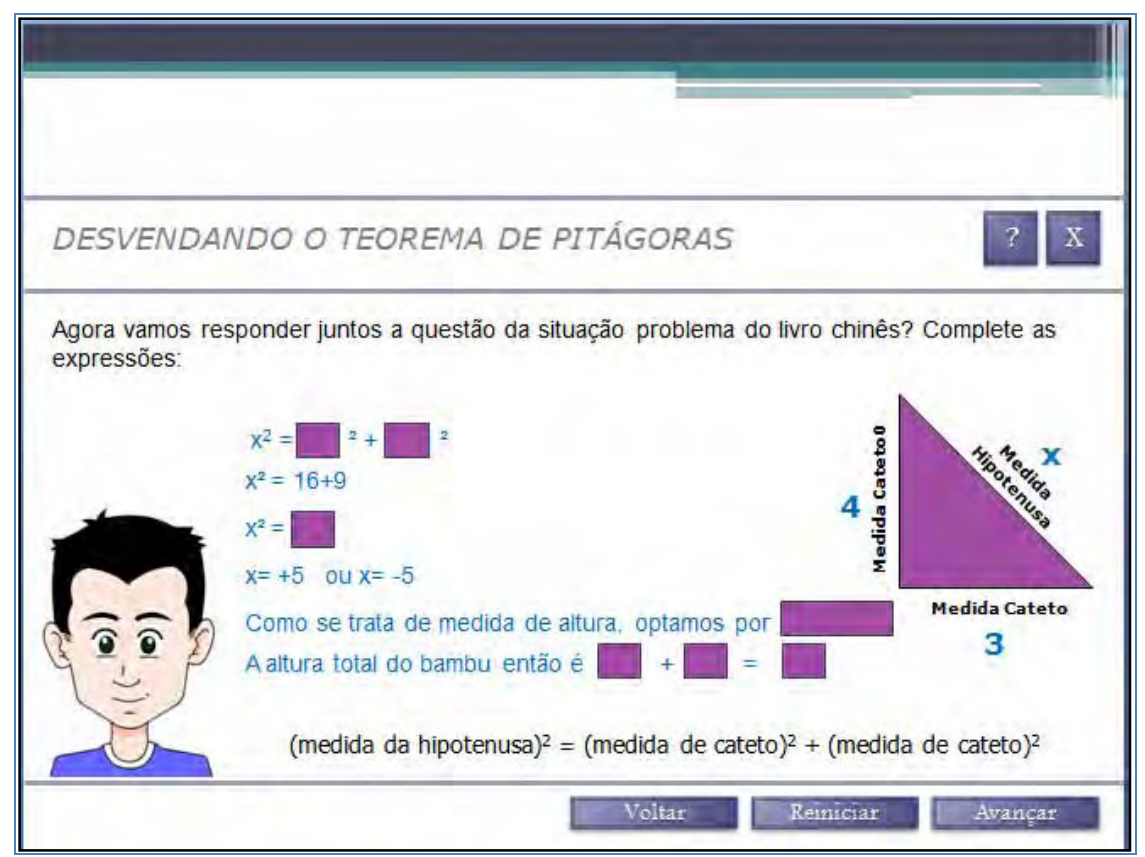

Figura 37 - Tela 7 - Recurso didático informatizado de PRA

A continuidade do preenchimento dos locais reservados estará dependente do valor anterior a ser preenchido. Essa programação da instrução poderá fornecer a PRA indício sobre o entendimento dos alunos sobre o Teorema de Pitágoras, pois o preenchimento correto das informações, na primeira sentença posta, indicará a identificação dos lados dos catetos.

Ainda sobre o preenchimento dos valores, foram planejadas algumas regras implícitas na programação:

- As caixas só aceitarão valores numéricos positivos;

- Enquanto não houver valor inserido na caixa atual, a(s) próxima(s) caixa(s) não deverão estar habilitada(s);

- Quando o aluno inserir o valor correto, o valor digitado é fixado e a próxima caixa a ser preenchida é habilitada e começa a pulsar;

- Quando o valor inserido não for o correto, o valor digitado é apagado e o aluno deverá digitar novamente.

Nesta tela, são trabalhas algumas das competências e habilidades parametrizadas pelo SARESP, tais como: H10. Efetuar cálculos que envolvam operações com números 
racionais (adição, subtração, multiplicação, divisão, potenciação - expoentes inteiros e radiciação); H19. Resolver problemas que envolvam equações do $2^{\circ}$ grau; H36. Resolver problemas em diferentes contextos, que envolvam as relações métricas dos triângulos retângulos. (Teorema de Pitágoras). Todas estas estão inseridas nas Competências do Grupo II, que são as competências para realizar.

As respostas esperadas dos alunos nesta atividade são:

$$
\begin{aligned}
& x^{2}=4^{2}+3^{2} \\
& x^{2}=25
\end{aligned}
$$

Como se trata de medida de altura, optamos por +5

A altura total do bambu então é $5+4=9$

Diante desta atividade, o recurso fornecerá a informação contingente às respostas emitidas pelos alunos sobre o desempenho alcançado por eles, como já explicado anteriormente. Portanto, ao finalizar o preenchimento dos dados solicitados e clicar no botão Avançar, o aluno obterá do recurso, automaticamente, se a sua resposta foi ou não correta por meio das seguintes telas:

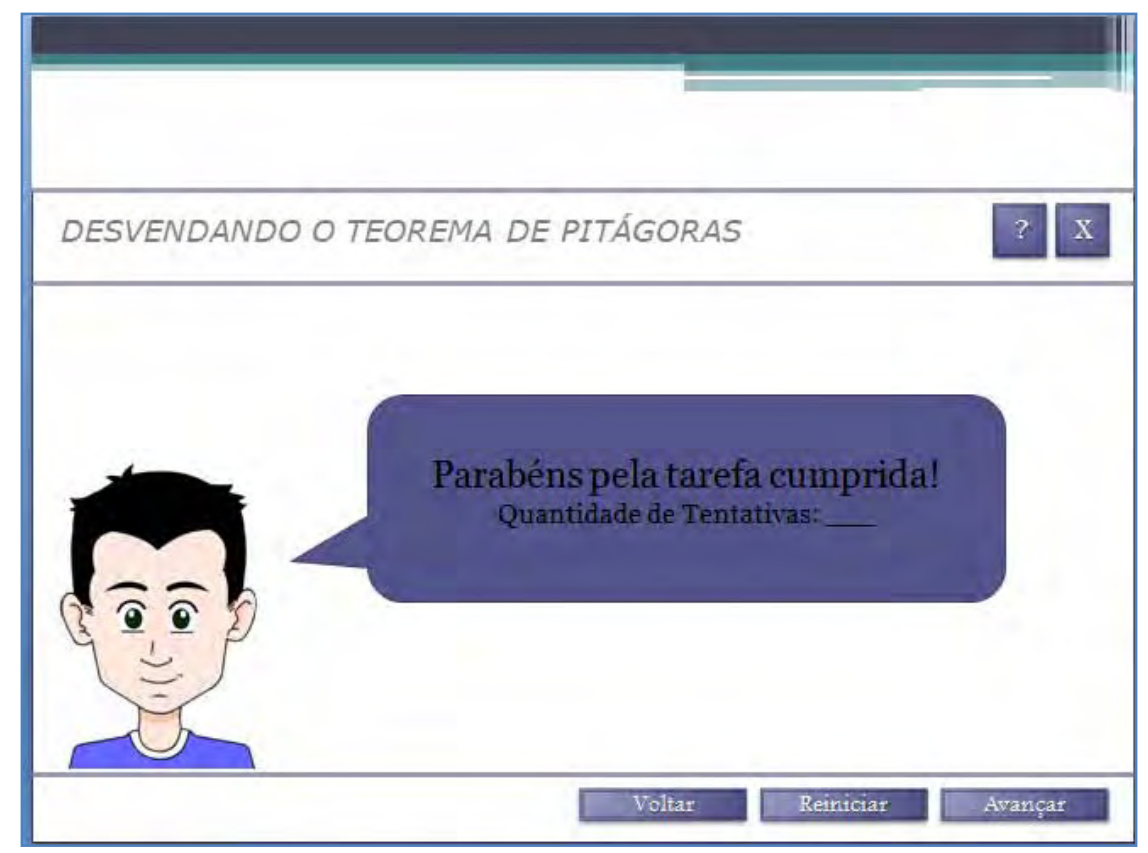

Figura 38 - Aluno cumpriu a atividade proposta 
Nesta tela será mostrada a quantidade de tentativas realizadas por cada um dos alunos. Essa informação poderá fornecer indícios sobre o entendimento dos alunos quanto à atividade proposta e, assim, permitirá que PRA possa reelaborar a atividade ou criar um novo plano de ensino que modifique a estratégia de abordagem sobre o teorema, incluindo aulas antecedentes ou subsequentes ao uso do recurso.

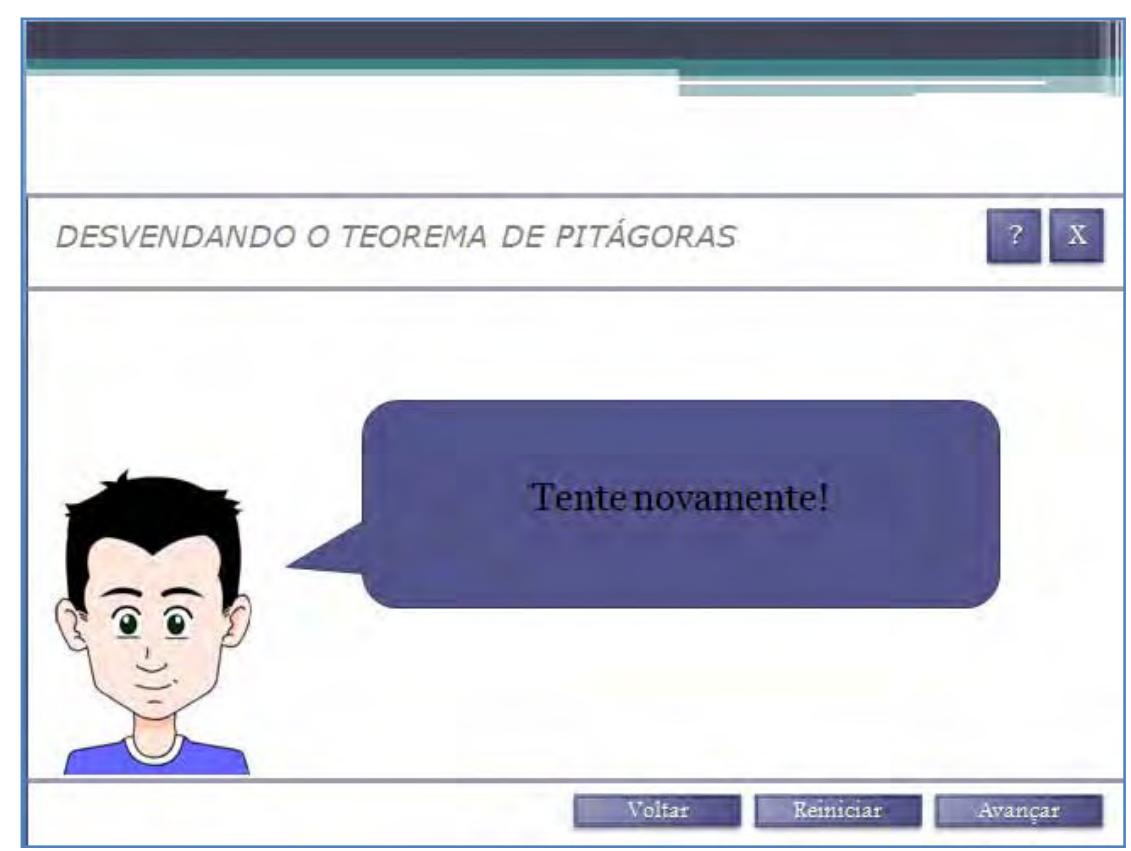

Figura 39 - Aluno deverá tentar cumprir a atividade novamente

Assim que o aluno finalizar essa atividade, o recurso planejado exibirá o conteúdo referente ao enunciado do Teorema de Pitágoras, como mostra a Figura 40: 


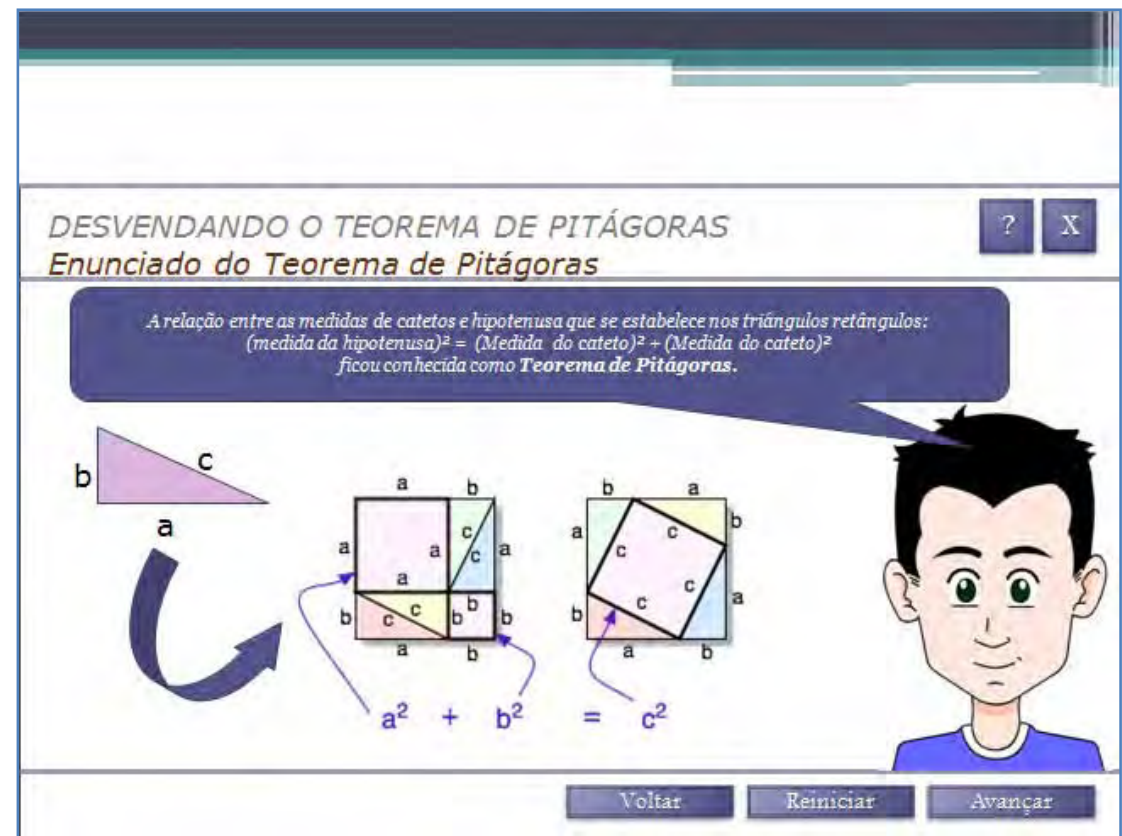

Figura 40 Tela 8 - Recurso Didático Informatizado de PRA

Essa tela apresenta uma animação, que é iniciada pela apresentação do triângulo retângulo abc. A personagem narra o texto $A$ relação entre as medidas de catetos $e$ hipotenusa que se estabelece nos triângulos retângulos: $(\text { medida da hipotenusa })^{2}=($ Medida do cateto $)^{2}+(\text { Medida do cateto })^{2}$ ficou conhecida como Teorema de Pitágoras. Em seguida, a personagem narrará outro texto Em todo e qualquer triângulo retângulo o quadrado da medida da hipotenusa é igual à soma dos quadrados das medidas dos catetos. Matematicamente, se c designar a hipotenusa e a e b os catetos, temos que ... . Emquanto a personagem narra o segundo texto, gradualmente, os elementos da segunda figura vão aparecendo:

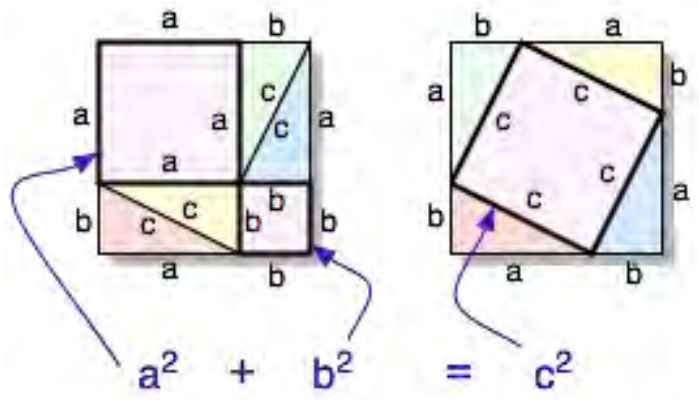

1. Surgem os quadrados ao mesmo tempo;

2. Os quadrados são divididos;

3. As figuras formadas são coloridas;

4. A equação que expressa a relação do teorema aparece por partes: primeiro $\mathrm{a}^{2}$ e uma flecha localizando-o na figura, em seguida, $b^{2}$ com uma flecha localizando-o na figura e, finalmente, $c^{2}$ e sua localização na figura. 
Na sequência, o personagem narrará o texto Arraste e sobreponha os triâgulos retângulos de mesma cor e verifique que a área do quadrado de lado a, mais a área do quadrado de lado b é igual a área do quadrado de lado c. Novamente, os alunos poderão interagir com a figura arrastando os triângulos retângulos de um quadrado para o outro na tentativa de sobrepor as figuras com as mesmas características. O lugar de origem das figuras que foram/são "arrastadas" ficarão em branco para que o aluno possa visualizar que as figuras foram deslocadas de sua posição original.

O aluno poderá arrastar os triângulos retângulos de ambas figuras, sendo que quando um triângulo retângulo for arrastado, o local ficará com o preenchimento vazio, podendo o mesmo receber uma outra figura. Caso o triângulo retângulo não seja arrastado para o local correto, o mesmo retornará para a posição de inicial, caso contrário, a figura será fixada e poderá ser arrastada novamente para ser fixada em outro local.

Esta atividade apresenta outra demonstração do Teorema de Pitágoras com a qual o aluno poderá interagir. Novamente, o recurso fornece condições para que o aluno produza a resposta esperada. Quando o aluno terminar suas interações com o recurso, ele poderá clicar em Avançar para ler o conteúdo sobre quem foi Pitágoras:

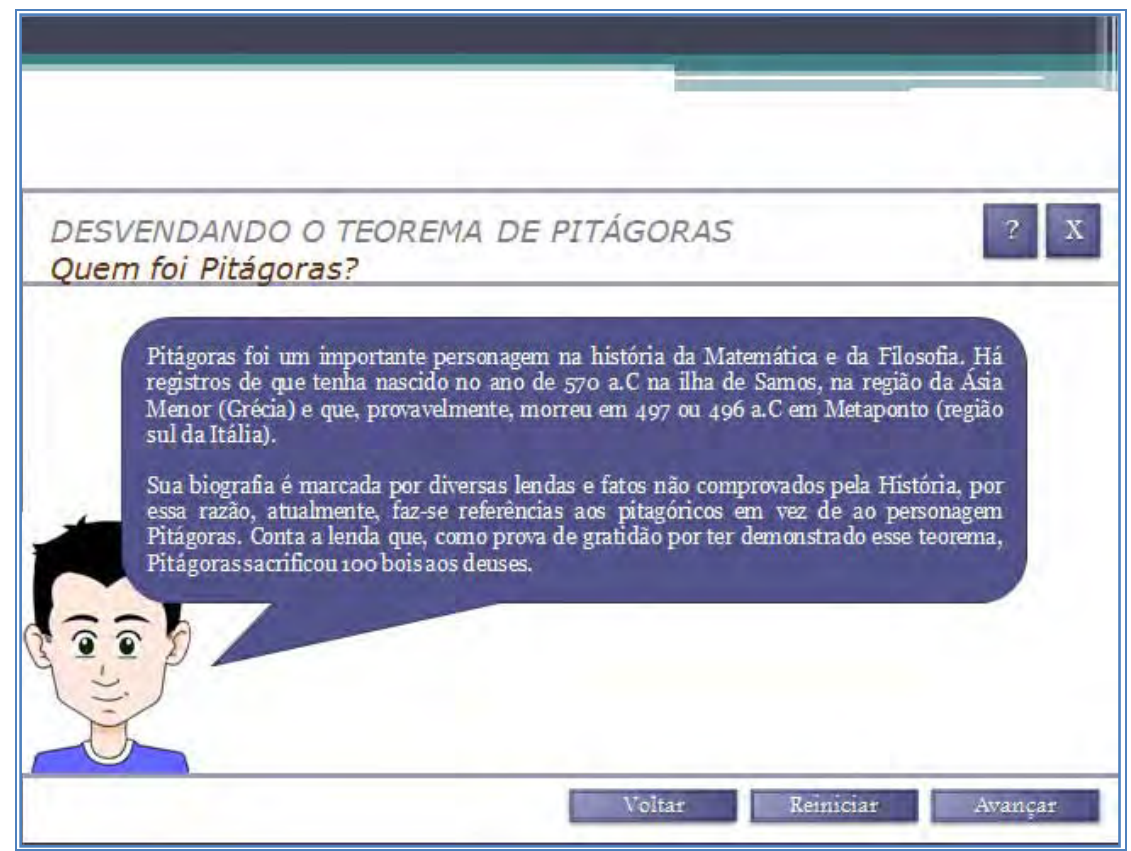

Figura 41 - Tela 9 - Recurso Didático Informatizado de PRA 
Assim que o aluno terminar de ler sobre quem foi Pitágoras, deverá clicar em Avançar.

Este conteúdo introdutório, da mesma forma como o conteúdo inicial sobre resolução de problemas envolvendo as propriedades de um triângulo retângulo, remetendo essa resolução a outras épocas de nossa história, disponibiliza novamente possibilidades de exploração de outras habilidades. PRA poderia elaborar uma atividade em sala de aula, que favorecesse a pesquisa sobre quem foi Pitágoras. Os alunos poderiam trabalhar em grupos na produção de textos para discussão em sala de aula, elencando os recursos disponíveis na época, como eles entenderam a trajetória de Pitágoras para enunciar o Teorema, entre outras atividades. Desta forma, novamente, as habilidades a serem desenvolvidas pelos alunos poderiam ser relacionadas às Competências de Grupo III, ou seja, competências para compreender historicamente a construção do conceito matemático.

Na próxima tela, o aluno deverá realizar uma atividade.

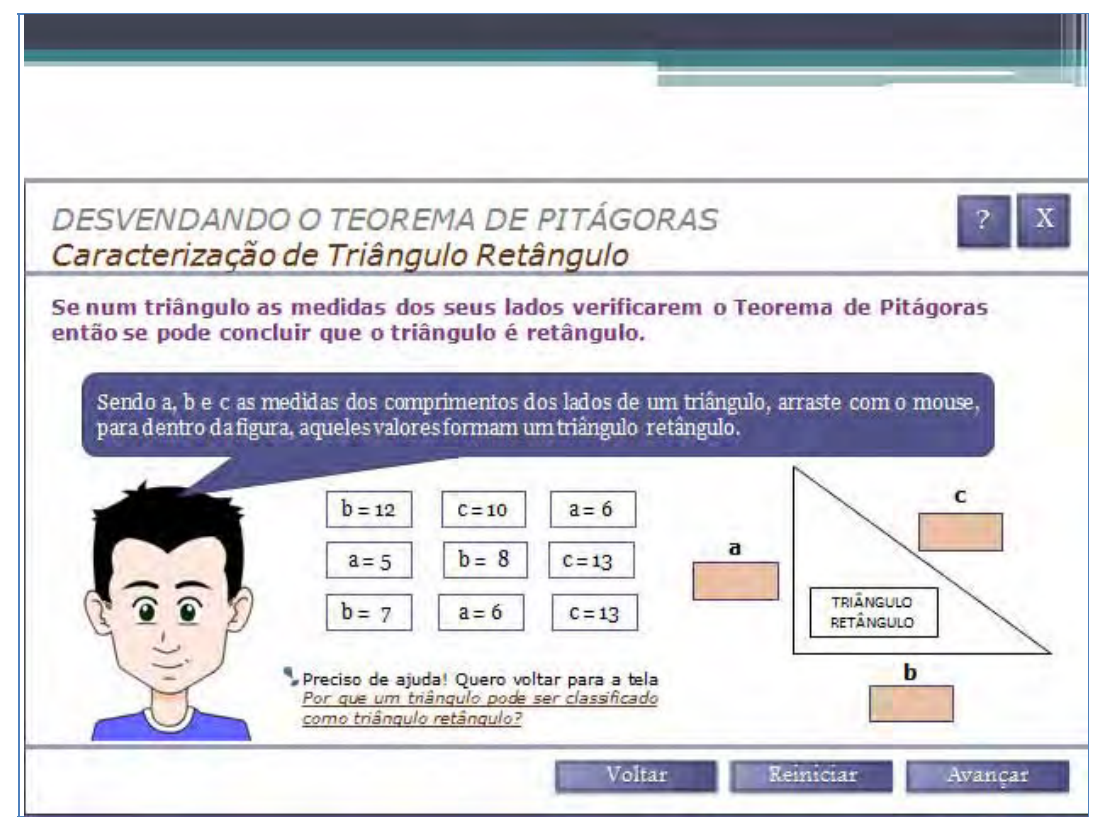

Figura 42 - Tela 10 - Recurso Didático Informatizado de PRA

Nesta atividade, o aluno deverá "arrastar" o conjunto de valores de medidas para os lados que determinam o triangulo retângulo abc. O aluno poderá acessar o aplicativo calculadora do computador para efetuar operações, sempre que considerar necessário. Outro recurso disponível é o link inserido logo abaixo das opções de conjunto de valores. Se o aluno considerar importante retomar os conteúdos vistos na tela Por que um triângulo pode ser classificado como triângulo retângulo?, ele poderá visualizá-los, clicando no link. 
Se o aluno arrastar os valores de medidas que formam um triangulo retângulo, ou seja, quando $c^{2}=a^{2}+b^{2}$, eles serão fixados na figura. Se os valores arrastados não formarem um triângulo retângulo, quando $\mathrm{c}^{2} \neq \mathrm{a}^{2}+\mathrm{b}^{2}$, os mesmos deverão voltar automaticamente para o local de origem. Quando todos os valores corretos forem arrastados o aluno será direcionado à tela com a mensagem de atividade cumprida com a informação sobre o número de tentativas realizadas para concluir a atividade.

Em seguida, será apresentado um novo desafio para que ele resolva. Esse desafio é uma situação problema, que o aluno deverá interpretar para conseguir solucionar a questão.

O problema a ser resolvido é o seguinte: De posse de um mapa, o motorista de um caminhão de entrega de eletrodomésticos precisa saber qual a distância entre as cidades a e b, pois dependendo da distância precisa abastecer o caminhão para não ter surpresas desagradáveis na viagem, como: falta de combustível ou atraso na entrega. Insira valores que completem corretamente as sentenças e ajude o motorista a descobrir a distância.

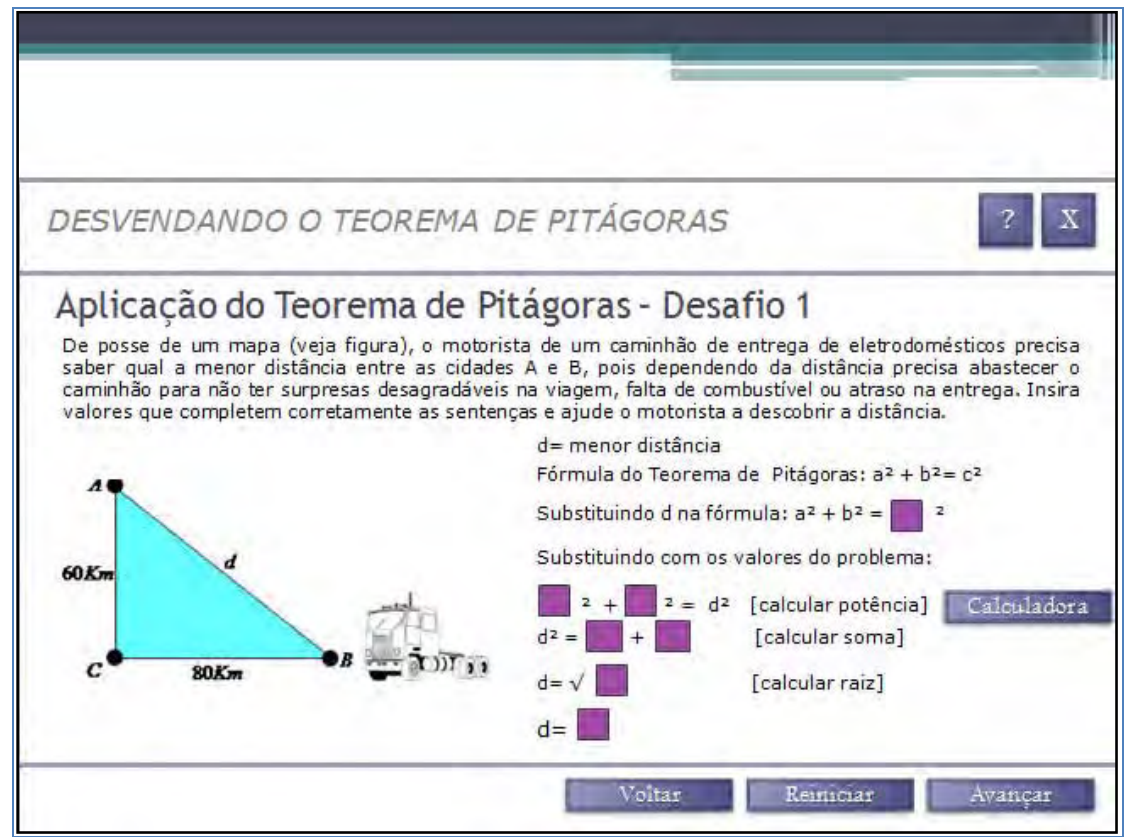

Figura 43 - Tela 11 - Recurso didático informatizado de PRA

O aluno deverá identificar a distância como a hipotenusa para assim, iniciar a resolução do problema. Essa atividade está baseada nos conteúdos abordados anteriormente no recurso. Com isso, espera-se que os alunos realizem o preenchimento das lacunas de valores retomando os conteúdos que já foram abordados.

As respostas esperadas para este exercício são:

Substituindo d na fórmula: $\mathrm{a}^{2}+\mathrm{b}^{2}=\mathbf{d}^{2}$ 
Substituindo com os valores do problema: $\mathbf{8 0}^{2}+\mathbf{6 0}^{2}=\mathrm{d}^{2}$

$$
\begin{aligned}
& d^{2}=6400+3600 \\
& d=\sqrt{10000} \\
& d=100 \mathrm{Km}
\end{aligned}
$$

Neste exercício as habilidades do SARESP trabalhadas são as seguintes: H36. Resolver problemas em diferentes contextos, que envolvam as relações métricas dos triângulos retângulos. (Teorema de Pitágoras); H15. Resolver problemas com números racionais que envolvam as operações (adição, subtração, multiplicação, divisão, potenciação e radiciação); H19. Resolver problemas que envolvam equações do $2^{\circ}$ grau.

Assim que o aluno completar o exercício corretamente, ele poderá ter acesso ao próximo desafio, clicando no botão Avançar.

Na próxima tela (Figura 44), o aluno deverá inserir um valor numérico no local indicado que completem corretamente a sentença matemática, a fim de encontrar uma solução para a situação proposta. Para isso, ele terá que analisar a figura apresentada e, então, responder ao exercício.

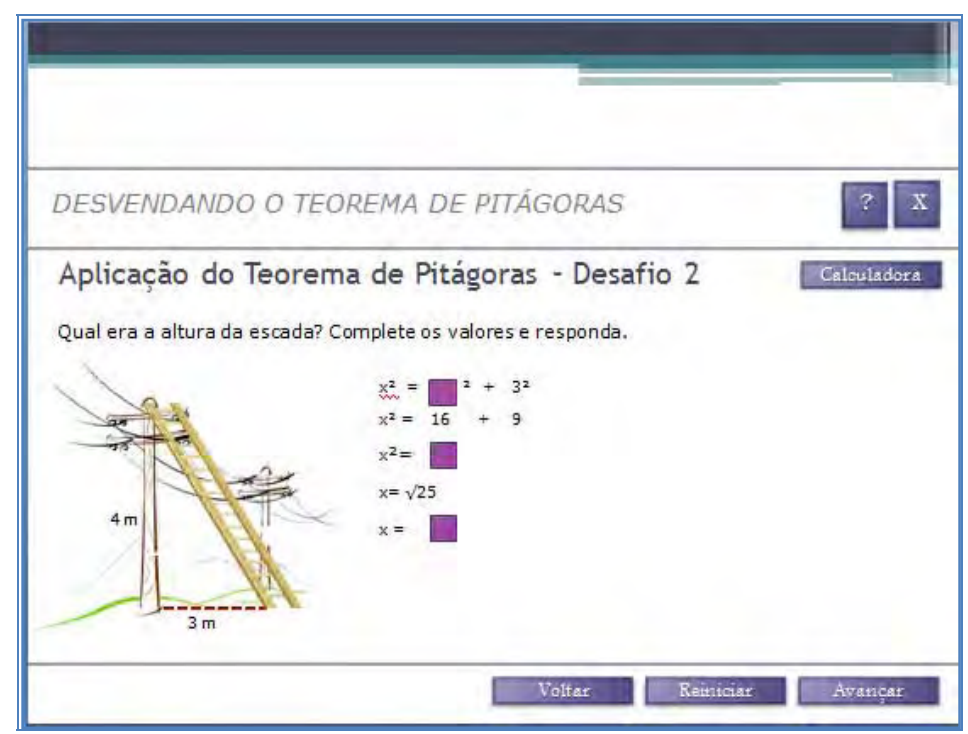

Figura 44 - Tela 12 - Recurso didático informatizado de PRA

As respostas esperadas para este exercício são:

- $\mathrm{x}^{2}=\mathbf{4}^{2}+3^{2}$

- $\mathrm{X}^{2}=\mathbf{2 5}$

- $\mathrm{x}=\mathbf{5} \mathbf{m}$ 
Assim que o aluno completar o exercício corretamente, ele poderá ter acesso ao próximo desafio, clicando no botão Avançar.

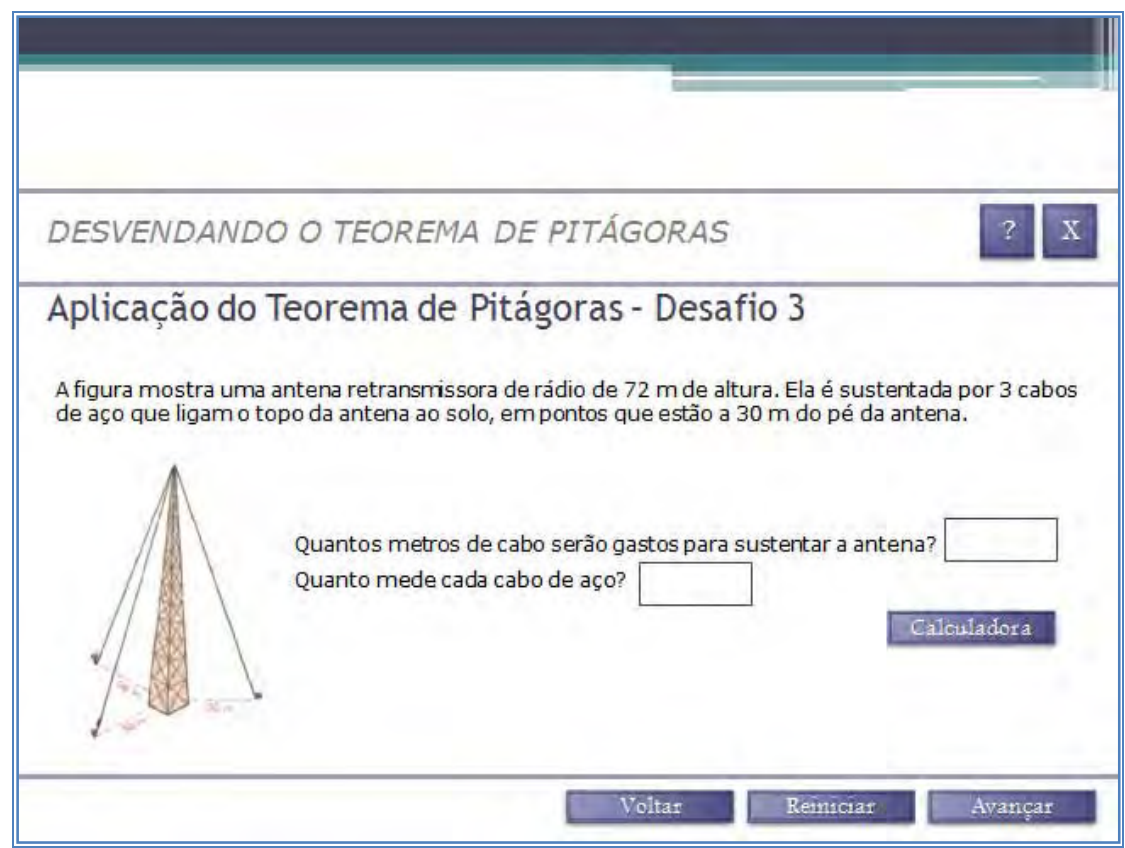

Figura 45 - Tela 13 - Recurso didático informatizado de PRA

As respostas esperadas para este exercício são:

- Quanto mede cada cabo de aço? R: 78

- Quantos metros de cabo serão gastos para sustentar a antena? R: 234 m

Assim que o aluno completar o exercício corretamente, ele poderá ter acesso ao próximo desafio, clicando no botão Avançar.

A próxima tela apresenta um resumo sobre as atividades realizadas por meio deste recurso, sendo que, ao clicar sobre cada um dos itens apresentados, o aluno poderá voltar a consultar o conteúdo correspondente. 


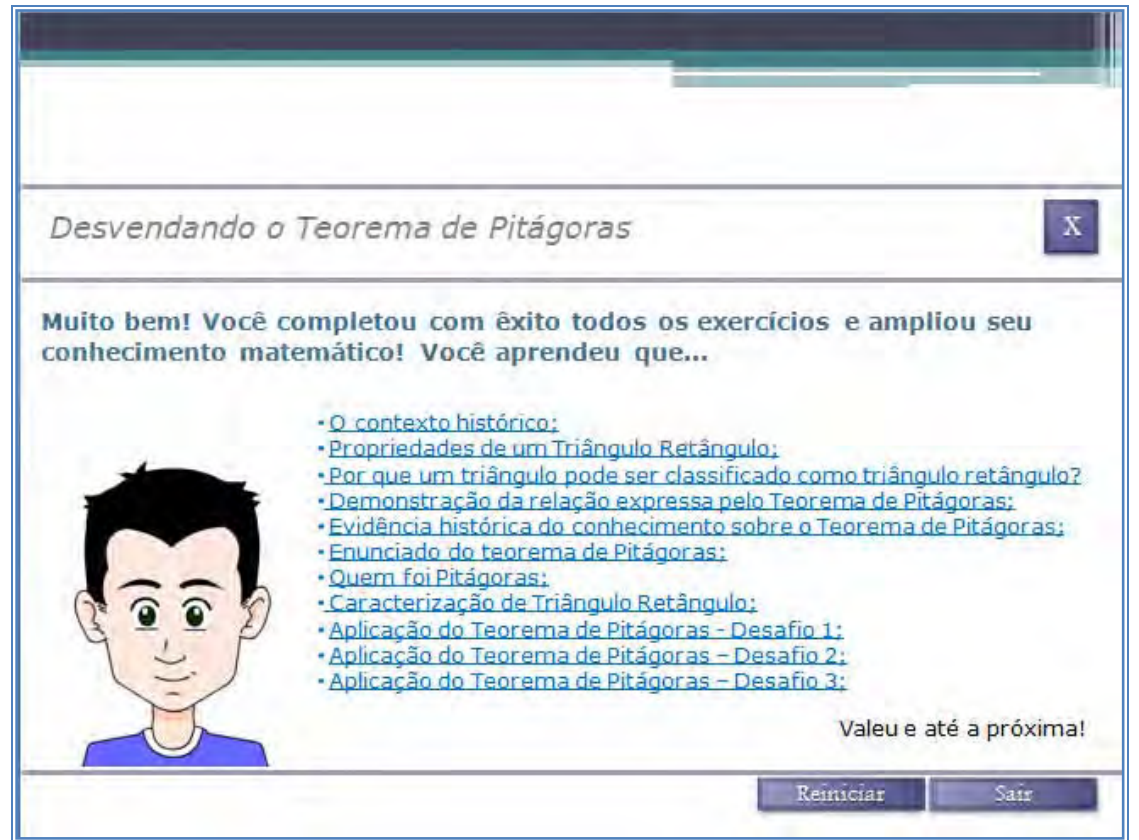

Figura 46 - Tela 14 - Recurso didático informatizado de PRA

A proposta elaborada para PRA e descrita neste tópico modifica a programação de ensino identificada durante as análises dos vídeos registrados. Sendo assim, o planejamento proposto para PRA está descrito a seguir.

Como primeira medida, entendemos que é possível tratar os temas das duas Unidades Didáticas em um plano de ensino único, no qual o aluno poderá percorrer uma sequência na qual o Teorema é apresentado e, em seguida, as atividades são apresentadas.

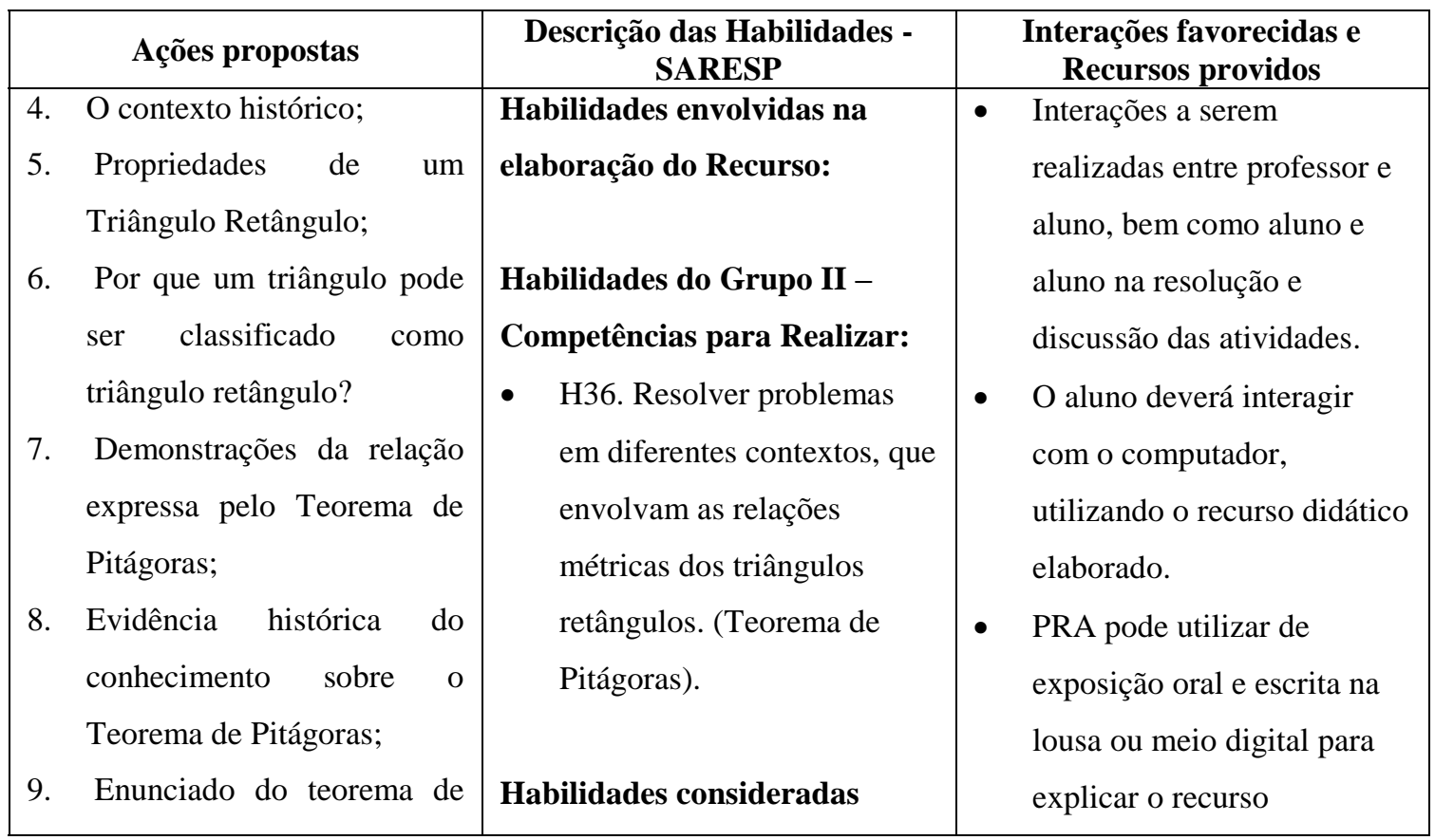




\begin{tabular}{|c|c|c|}
\hline Ações propostas & $\begin{array}{c}\text { Descrição das Habilidades - } \\
\text { SARESP }\end{array}$ & $\begin{array}{l}\text { Interações favorecidas e } \\
\text { Recursos providos }\end{array}$ \\
\hline $\begin{array}{l}\text { Pitágoras; } \\
\text { 10. Quem foi Pitágoras; } \\
\text { 11. Caracterização de } \\
\text { Triângulo Retângulo; } \\
\text { 12. Aplicação do Teorema de } \\
\text { Pitágoras. }\end{array}$ & $\begin{array}{l}\text { como Conhecimentos Prévios: } \\
\text { Habilidades do Grupo II - } \\
\text { Competências para Realizar: } \\
\text { - } \quad \text { H10. Efetuar cálculos que } \\
\text { envolvam operações com } \\
\text { números racionais (adição, } \\
\text { subtração, multiplicação, } \\
\text { divisão, potenciação - } \\
\text { expoentes inteiros e } \\
\text { radiciação); } \\
\text { H24. Identificar } \\
\text { propriedades de triângulos } \\
\text { pela comparação de } \\
\text { medidas de lados e ângulos. } \\
\text { Habilidades do Grupo III - } \\
\text { Competências para } \\
\text { Compreender: } \\
\text { H19. Resolver problemas } \\
\text { que envolvam equações do } \\
2^{\circ} \text { grau. }\end{array}$ & $\begin{array}{l}\text { elaborado. } \\
\text { PRA deve ficar atenta às } \\
\text { resoluções dos exercícios dos } \\
\text { alunos, } \\
\text { informações contingentes às } \\
\text { repostas emitidas que a } \\
\text { permitam arranjar essas } \\
\text { contingências, mesmo durante a } \\
\text { aula. }\end{array}$ \\
\hline
\end{tabular}




\section{CONCLUSÕES}

Mesmo considerando as orientações sobre como os alunos serão avaliados e sobre o que se espera em termos do desenvolvimento de competências e habilidades explicitadas nas Propostas Curriculares do Estado de São Paulo e no SARESP, este trabalho se propôs a investigar em que extensão as práticas de ensino de professores que ministram conteúdos de matemática no Ensino Fundamental - Ciclo I e II sustentariam assistências em duas dimensões da Proposta Curricular do Estado de São Paulo: a) com os conteúdos previstos; b) com as respectivas competências relacionadas às áreas e aos temas dos conteúdos ministrados. Assim, a seguinte indagação orientou as investigações relatadas nesta dissertação: De que modo, a saber, mediante quais instrumentos metodológicos, recursos didáticos poderiam ser desenvolvidos com fundamentação em características das ações profissionais de professores em sala de aula, ou seja, a partir das práticas de ensino e de avaliação emitidas pelo professor em interação com os alunos em sala de aula?

Para responder a essa questão, foram estabelecidos dois objetivos:

1. Caracterizar as práticas de ensino de professores da rede pública estadual que ministram conteúdos da matemática nos Ciclo I e II do Ensino Fundamental, com ênfase na identificação e na descrição de consistências entre as contingencias de ensino registradas e os conteúdos e competências preconizadas pela proposta Curricular e pelas Matrizes de Referências do SARESP.

2. Verificar se a caracterização das práticas de ensino efetuadas no item anterior se constituiria em condição favorecedora para o delineamento de recursos instrucionais para o ensino de conteúdos curriculares da área de Matemática previstos na proposta curricular do Estado de São Paulo, bem como para o desenvolvimento das competências definidas nas Matrizes de Referência do SARESP.

O primeiro objetivo justificou a execução das três primeiras etapas previstas no Procedimento de Descrição e Análise desta pesquisa. Para realizar o segundo objetivo, foi necessário estabelecer novas etapas que foram descritas no Procedimento de Propostas para recursos didáticos informatizados.

Com isso, na Etapa 1, do Procedimento de Descrição e Análise ocorreu a seleção dos registros em vídeo de duas unidades didáticas, que subsidiariam as análises realizadas em 
etapas posteriores e a caracterização das aulas ministradas. Portanto, nesta etapa, durante a exibição contínua dos vídeos, as habilidades e competências parametrizadas pelo SARESP foram vinculadas às práticas de ensino das professoras.

$\mathrm{Na}$ Etapa 2, diante da tabela de caracterização, ocorreram as descrições e as análises das interações observadas e registradas, perante às caracterizações realizadas na Etapa 1. Para cada habilidade vinculada, foi registrada a transcrição dos registros dos vídeos, para apontar os comportamentos dos alunos diante das ações e condições fornecidas pelas professoras. Após a transcrição, os comportamentos dos alunos foram descritos e analisados para cada habilidade vinculada.

A Etapa 3 previu a síntese das análises das UDs, salientando as ocorrências de ações mais incidentes nas práticas de ensino de PRA e PMA. Essa síntese teve como objetivo fornecer subsídios com os quais os recursos didáticos informatizados foram delineados.

Ao concluir as etapas do Procedimento de Descrição e Análise, a pesquisadora iniciou as etapas do Procedimento de Propostas para recursos didáticos informatizados, que também foi realizado em três etapas.

A Etapa 1 deste procedimento teve como objetivo descrever a programação do ensino de cada UD observada durante as análises. Diante da descrição, constatou-se que, PMA em suas duas unidades e PRA em sua primeira unidade, percorreram uma sequência na qual houve variações entre habilidades, grupos de competência e, até mesmo, sobre temas. Essa sequência pode ter influenciado a compreensão e as motivações dos alunos ao realizarem os exercícios, uma vez que as respostas registradas, muitas vezes, mostraram-se antagônicas e, as respostas corretas (previstas), induzidas, mediante a forma com a qual as correspondências entre as indagações e os temas propostos foram elaborados por PMA e PRA.

Embora, pelas análises dos vídeos, muitas vezes, seja inconclusiva a medida com a qual os alunos realmente conseguiram identificar ou reconhecer as propriedades do conteúdo curricular previsto, fica a indagação se houve consistências nas práticas de ensino de PRA e PMA, diante das variações entre as habilidades, grupos de competências e temas, uma vez que, algumas dessas habilidades e competências podem ser entendidas como conhecimentos prévios dos alunos para as atividades propostas na sala de aula.

Na Etapa 2, do Procedimento de Proposta dos recursos didáticos, foram elencadas as principais características das práticas de ensino de PMA e PRA. A lista das características permitiu a escolha de determinadas características que seriam consideradas no delineamento do recurso didático. 
Em seguida, na Etapa 3, com os dados referentes às etapas anteriores, o delineamento do recurso didático informatizado foi elaborado. Entende-se que a elaboração de um material e sua inclusão na interação entre professor e aluno não reflete necessariamente a mudança da prática de ensino. Porém, o objetivo deste trabalho não é discutir a mudança na prática, mas sim, o delineamento de um recurso a partir de sua análise, buscando delinear um recurso que leve em consideração as interações ocorridas no ambiente de sala de aula, a partir dos comportamentos emitidos pelos alunos, diante das ações das professoras.

Diante das etapas realizadas no Procedimento de Descrição e Análise, foi possível observar que PMA, em suas duas unidades didáticas, elabora situações relacionadas ao Tema 4 - Tratamento de Informação previsto pelo SARESP, com foco em habilidades para leitura e criação de tabelas.

Já para PRA, constatou-se a elaboração de situações de ensino que abordam o tema Teorema de Pitágoras, variando entre habilidades relacionadas às áreas de geometria e álgebra, principalmente, com relação às habilidades H19 - Resolver problemas que envolvam equações de $2^{\circ}$. Grau e H36 - Resolver problemas em diferentes contextos, que envolvam as relações métricas dos triângulos retângulos.

Tanto PMA quanto PRA, segundo a análise, centram suas práticas de ensino em interações que privilegiaram suas ações orais, principalmente. De acordo com o registrado, os alunos emitiram respostas orais de estimativas, o que prescindiu da elaboração das análises sobre os conteúdos em estudo para a emissão das respostas, uma vez que estas foram realizadas pelas professoras. Diante destas práticas, constatou-se que as professoras elaboraram intervenções que ocasionaram desempenhos não compatíveis com as medidas de aprendizagem preconizadas nas Propostas Curriculares e no SARESP, demarcando o distanciamento entre as orientações didáticas estabelecidas nestes documentos, fundamentadas no ensino centrado no aluno e voltado para o desenvolvimento de habilidades e competências.

Ainda sobre as práticas de ensino, as condições estabelecidas nas interações com os alunos, durante a observação, mostram que PRA e PMA resolvem os exercícios pelos alunos, restringindo à participação deles à função de repetir ou fornecer dados (lidos a partir de materiais entregues ou cálculos realizados) para a resolução de um exercício, sendo que o procedimento de resolução foi realizado por elas.

Outra característica das práticas das duas professoras constatada é a omissão em explorar as possíveis relações de controle que determinaram a emissão de respostas pelos 
alunos distintas das previstas, bem como das respostas previstas. Neste caso, cabe destacar dois aspectos:

a) Para Skinner (1964; p. 16) o aluno, em sala de aula, depende da professora para saber se está ou não certo em sua resposta, sendo assim, a frequência de reforço é imprescindível para o aluno, uma vez que o "... aluno é "ensinado" no sentido de que é induzido a se engajar em novas formas de comportamento e em formas específicas em situações específicas." (Skinner, 1964; p. 31)

b) O plano de ensino é constituído por um arranjo sucessivo de contingências de reforço. Ao prescindir de explorar tais relações de controle, PMA e PRA também prescindiu de analisar sua própria prática, não estabelecendo novas relações e/ou condições para que os alunos pudessem emitir as respostas esperadas.

Diante destas observações, em termos de caracterização das interações, foi possível constatar algumas características comuns entre as professoras, como por exemplo, o registro de práticas baseadas no ensino prioritariamente transmissivo do conhecimento e regras expostas independentemente de medidas prévias de aprendizagem.

Do mesmo modo, foram fornecidas instruções orais e escritas repetitivas. Tais instruções sobre o assunto a ser estudado ou atividades a serem executadas pelos alunos, foram dadas prescindindo da obtenção de medidas graduais de aprendizagem, de prérequisitos ou, então, de medidas de respostas que não eram previstas.

Com isso, constata-se que é inconclusiva a descrição das características de desempenho dos alunos com relação ao desenvolvimento das competências e habilidades previstas, pois as programações de ensino elaboradas e a forma como estas foram conduzidas não fornecem subsídios suficientes sobre o aprendizado dos alunos.

Os recursos didáticos informatizados delineados neste trabalho tiveram como subsídio algumas das características identificadas a partir das análises das práticas de ensino de PRA e PMA. Foram propostos dois recursos, sendo um para cada professora e tema abordado nas UDs, fornecendo uma nova ferramenta em um contexto diferente, com o objetivo de auxiliar a obtenção de medidas comportamentais sobre os desempenhos dos alunos e que essas medidas possam ser analisadas diante de dados sobre os desempenhos relacionados às competências e habilidades que foram estabelecidas pela programação dos recursos. 
Os principais aspectos que nortearam o delineamento dos recursos didáticos foram:

a) Fornecer condições com as quais os alunos possam interagir com o recurso de forma que eles próprios elaborem as respostas das atividades propostas.

b) A programação de consequências imediatas contingentes às respostas dos alunos.

Levando em consideração os dois aspectos acima citados, espera-se que os recursos planejados favoreçam condições para a emissão de repertórios consistentes com as habilidades priorizadas no planejamento de cada um deles e para que, no momento de sua utilização, o professor tenha condições de realizar intervenções, diante dos comportamentos emitidos pelos alunos ao interagir com o recurso.

Diante do comportamento do aluno em interação com o recurso, dois aspectos são prioritariamente importantes:

a) Como o recurso está programado para emitir consequências imediatas contingentes às respostas dos alunos, o professor pode ter a medida de desempenho do aluno, pelo registro das respostas, o número de tentativas, analisando, assim, o desempenho do aluno.

b) Se o aluno estiver com dificuldades em utilizar o recurso ou entender a atividade, provavelmente, a programação da mesma deverá ser alterada ou ter sua sequência ampliada. Para Skinner (1964; p. 48), geralmente, o professor, ao estabelecer um programa e iniciá-lo com os alunos, perceberá que omitiu ou negligenciou etapas importantes ou pontos relevantes do conteúdo na sequência programada. Isso, provavelmente, será percebido durante a interação dos alunos com o recurso.

Então, os recursos, tela a tela, apresentam questões objetivas a serem respondidas com a expectativa de que o aluno possa, diante de uma questão, analisar as informações que naquela tela foram solicitadas. Essa programação foi produzida, com o objetivo de evitar questionamentos muito gerais para o aluno com relação aos conteúdos abordados; outra característica identificada nas análises das práticas de ensino de PMA e PRA. Com isso, o aluno é preparado para o próximo passo, ou seja, a programação realizada para a proposta do recurso apenas fornece acesso ao próximo passo, se e somente se, o ponto abordado anteriormente for respondido corretamente. 
Ainda com a utilização dos recursos, espera-se que seja possível disponibilizar uma ferramenta que forneça condições às professoras para identificar as fontes de controles de estímulos dos alunos, compreendendo, aluno a aluno, quais são os caminhos percorridos por eles para emitirem uma determinada resposta. Outro ponto importante, na realização das atividades, é o estabelecimento de condições, nas quais os alunos precisam identificar o que é solicitado pelo problema, compreender quais dados serão utilizados na resolução do mesmo e realizar os cálculos para cumprir a atividade, quando esta assim solicitar. Essa programação tem como objetivo ampliar as condições para que os alunos realizem as análises, o que em sala de aula, muitas vezes, foram ações realizadas pelas próprias professoras.

Durante uma aula, na qual este recurso poderia ser utilizado, as professoras poderiam acompanhar seus alunos na interação com o recurso. Esse acompanhamento poderia fornecer a elas indício sobre o desempenho individual dos alunos. E, assim, estabelecer novos arranjos de contingências ao perceber/analisar as informações contingentes às respostas dos alunos.

A inclusão de recursos didáticos informatizados pode trazer para o professor uma ferramenta que forneça a ele meios de avaliação baseada na produção das repostas dos alunos, embora, essa interação do aluno com o recurso, esteja intimamente ligada às estratégias de ensino para inclusão do recurso como material didático em suas aulas.

O olhar para a sala de aula e como as interações aluno - material didático professor ocorrem neste ambiente, mostra-se como alternativa para a elaboração de recursos didáticos informatizados, uma vez que estes podem ser delineados de forma a ampliar possibilidades que interfiram em como as interações ocorrem em sala de aula.

Em síntese, esses recursos didáticos informatizados consistiram em vincular os comportamentos dos alunos mediante as ações das professoras com a produção de possíveis medidas comportamentais das habilidades e das competências preconizadas pelo SARESP em diferentes séries do Ensino Fundamental. 


\section{REFERÊNCIAS}

AZEVEDO, M.C. de C. C. de. Os Saberes Docentes na ação pedagógica dos estagiários de Música: dois estudos de caso. Tese de doutorado. Universidade Federal do Rio Grande do Sul, 2007.

BAGgiO, S. C. R. Política Educacional, SARESP e Discurso de Professores: vozes constituídas e constituintes de um sistema e a subjetividade dos professores. Dissertação de Mestrado. Universidade de Taubauté, 2005.

BARRETO, R. G. Tecnologia e educação: trabalho e formação docente. Educ. Soc., Campinas, vol. 25, n. 89, p. 1181-1201, Set./Dez. 2004 Disponível em [http://www.cedes.unicamp.br]. Acessado em 06/03/2010.

BARRETO, R. G.; GUIMARÃES, G. C.; LEHER, E. N. T. As tecnologias da informação e da comunicação na formação de professores. Revista Brasileira de Educação, v. 11, n. 31, jan./abr./ 2006. Disponível em: [http://www.scielo.br/pdf/rbedu/v11n31/a04v11n31.pdf]. Acessado em 06/03/2010.

BASTOS, F.; NARDI, R. Polêmicas sobre abordagens para o Ensino de Ciências: uma análise, com ênfase na idéia da pluralidade metodológica. V ENCONTRO NACIONAL DE PESQUISA EM EDUCAÇÃO EM CIÊNCIAS, Nº 5, 2005.

BAUER, A. Uso dos resultados do SARESP: o papel da Avaliação nas políticas de formação docente. Dissertação de Mestrado. Faculdade de Educação da Universidade de São Paulo. 2006.

BAUM, W. Compreender o Behaviorismo: Ciência, comportamento e cultura. Porto Alegre: ArtMed Editora, 1999.

CARVALHO NETO, M. B. F. Skinner e as explicações mentalistas para o comportamento: Uma análise histórico-conceitual (1931-1959). Tese de Doutorado. Instituto de Psicologia. Universidade de São Paulo, 2001.

GIL-PÉREZ, D. Formação de professores de ciências: tendências e inovações; revisão técnica da autora: Anna Maria Pessoa de Carvalho; [tradução Sandra Valenzuela]. 8 ed. - São Paulo: Cortez, 2006. - (Coleção Questões da Nossa Época; v. 26).

GOVERNO DO ESTADO DE SÃO PAULO, Matrizes de referência para a avaliação SARESP: Sistema de Avaliação de Rendimento Escolar do Estado de São Paulo / Coord. Maria Inês Fini. - São Paulo: SEE, 2009.

GOVERnO DO ESTADO DE SÃO PAULO, Orientações Curriculares do Estado de São Paulo: Língua Portuguesa e Matemática - Ciclo I / Secretaria de Educação; Coord. Neide Nogueira, Telma Weisz; Elaboração, Ângela Maria da Silva Figueiredo e outros. São Paulo: FDE, 2008.

GOVERNO DO ESTADO DE SÃO PAULO, Proposta Curricular do Estado de São Paulo: Matemática / Coord. Maria Inês Fini. - São Paulo: SEE, 2008. 
KONRATH, M. L. P.; KAMPFF, A. J. C; GOMES, F. J. L; CARVALHO, M. J. S.; NEVADO, R. A. "Nós no Mundo: Objeto de Aprendizagem voltado para o $1^{\text {". Clico do }}$ Ensino Fundamental”. Novas Tecnologias na Educação, CINTED-UFRGS, v. 4, n. 1, Julho, 2006.

LELIS, I. A. Do ensino de conteúdos aos saberes do professor: mudança de idioma pedagógico? Educ. Soc., Campinas, v. 22, n. 74, 2001. Disponível em: <http://www.scielo.br/scielo.php?script=sci_arttext\&pid=S010173302001000100004\&lng=pt\&nrm=iso>. Acessado em 09/10/2009.

MATOS. M. A. Com o que o Behaviorismo Radical trabalha. In. BANACO, R.A et al. (Org.) Sobre Comportamento e Cognição (vol. 1). Santo André, SP: ArBytes Editora, p. 45-53, 1997a.

MATOS, M. A. O Behaviorismo Metodológico e suas relações com o mentalismo e o Behaviorismo Radical. R.A. BANACO et al. (Org.) Sobre Comportamento e Cognição (vol. 1). Santo André, SP: ArBytes Editora, p. 54-67, $1997 \mathrm{~b}$.

MATOS, M.A. Análise de Contingências no aprender e no ensinar. In: ALENCAR, E.S. (Org.). Novas Contribuições da Psicologia aos Processos de Ensino e Aprendizagem. São Paulo: Cortez, p.141-165, 1992.

MELARÉ, D; Wagner, A. J. Objetos de Aprendizagem virtuais: material didático para a educação básica. Revista Latinoamericana de Tecnologia Educativa, 4(2), 73-84 [http://www.unex.es/didactica/RELATEC/sumario_4_2.htm].

NUNES, C. M. F. Saberes Docentes e formação de professores: um breve panorama da pesquisa brasileira. Educ. Soc., Campinas, v. 22, n. 74, 2001. Disponível em: [http://www.scielo.br/scielo.php?script=sci_arttext\&pid=S0101-

$73302001000100003 \& \operatorname{lng}=$ pt\&nrm=iso]. Acessado em 09/10/2009.

NUNES, C.; GALLOTA, A. Objetos de aprendizagem a serviço do professor. Publicado em 2004. Disponível em: http://www.microsoft.com/brasil/educacao/parceiro/objeto_texto.mspx.

Acessado em 06/03/2010.

SAZDJIAN, A. B. As redações do SARESP: O Texto Argumentativo E A Análise Das

Três Pontas. Dissertação de Mestrado. 2007. Disponível em: [http://www.pucsp.br/pos/lael/laelinf/teses/site_anaid_sazdjian_ME_07_lael_pdf.pdf]. Acessado em 06/03/2010.

SÉRIO, M.T.P.A. O Behaviorismo Radical e a Psicologia como ciência. Revista Brasileira de Terapia Comportamental e Cognitiva, v. 7, n.2, 247-262, 2005.

SIDMAN, M. Tactics of scientific research: Evaluating experimental data in Psychology. New York: Basic Books, Inc. 1960.

SKINNER, B. F. Ciência e Comportamento Humano. Tradução: João Carlos Todorov,

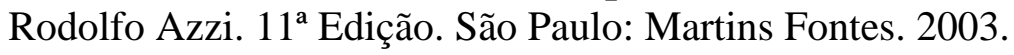

SKINNER, B. F. The Evolution of Behavior. The Journal of the Experimental Analysis of Behavior, vol. 41, n. 2, 217-221, 1984. 
SKINNER, B. F. Selection by consequences. Science, 213, 501-504, 1981.

SKINNER, B.F. About Behaviorism. New York, NY: Alfred A. Knopf., 1974.

SKINNER, B. F. Tecnologia do ensino. São Paulo: Herder, 1972a.

SKINNER, B.F. Cumulative Record: A selection of papers. $3^{\text {rd }}$. Edition. New York: Applenton-Century-Crofts, 1972 b.

SKINNER, B.F. Beyond freedom and dignity. New York,NY: Alfred A. Knopf, 1971.

SKINNER, B. F. The Verbal Behavior. New York: Applenton-Century-Crofts, 1957.

SKINNER, B. F. Science and human behavior. New York, NY: McMillan, 1953.

SKINNER, B.F. The Operational Analysis of Psychological Terms. Psychological Review, 52, 270-277, 1945.

SOUZA, D. das G. O que é contingência?. Mesa Redonda Primeiros Passos: Aprenda o Básico. IV Encontro Brasileiro de Terapia e Medicina Comportamental. Campinas. 1995. [http://www.buk.xpg.com.br/textos/contingencia.htm]. Acessado em 09/10/2009.

SPARVOLI, D. Recurso interpretativo funcional como o Saber Docente no Ensino de Conteúdos Curriculares de Matemática. Dissertação de Mestrado: Programa de PósGraduaçãoo de Psicologia do Desenvolvimento e Aprendizagem. Bauru, SP: Universidade Estadual Paulista, 2008.

TOURINHO, E. O Autoconhecimento na Psicologia Comportamental de B. F. Skinner. Belém: Editora Universidade Federal do Pará/CFCH, 1995.

VALENTE, J. A. Por quê o computador na educação? In: Computadores e conhecimento repensando a educação. Campinas: UNICAMP/NIED.1993.

VAZ, R. A da C.SARESP/2005: Uma análise de questões de matemática da 7a. Série do Ensino Fundamental, sob a ótica dos níveis de mobilização de conhecimentos e dos registros de representação semiótica. Dissertação de Mestrado. Pontifícia Universidade Católica de São Paulo, 2008.

ZANOTTO, M.L. Formação de Professores: Contribuições da Análise do Comportamento. São Paulo: EDUC/FAPESP, 2000.

Wiley, D. A. Connecting learning objects to instructional design theory: A definition, a metaphor, and a taxonomy. In D. A. Wiley (Ed.), The Instructional Use of Learning Objects: Online Version. Disponível em: [http://reusability.org/read/chapters/wiley.doc]. Acessado em 02/11/2008. 